University of Rhode Island

DigitalCommons@URI

Open Access Master's Theses

1987

\title{
Municipal Water Quality Planning in Rhode Island
}

Nancy Hall

University of Rhode Island

Follow this and additional works at: https://digitalcommons.uri.edu/theses

\section{Recommended Citation}

Hall, Nancy, "Municipal Water Quality Planning in Rhode Island" (1987). Open Access Master's Theses.

Paper 710.

https://digitalcommons.uri.edu/theses/710

This Thesis is brought to you for free and open access by DigitalCommons@URI. It has been accepted for inclusion in Open Access Master's Theses by an authorized administrator of DigitalCommons@URI. For more information, please contact digitalcommons-group@uri.edu. 
MUNICIPAL WATER QUALITY PLANNING

IN

RHODE ISTAND

BY

NANCY HALU

A Research Project Submitted in Partial Fulfillment

of the Requirements for the Degree of

Master in Comminity Planning

University of Rhode Island

1987 
MASTER OF COMMNITY PLANNING

RESEARCH PROJECT

OF

NANCY HALL

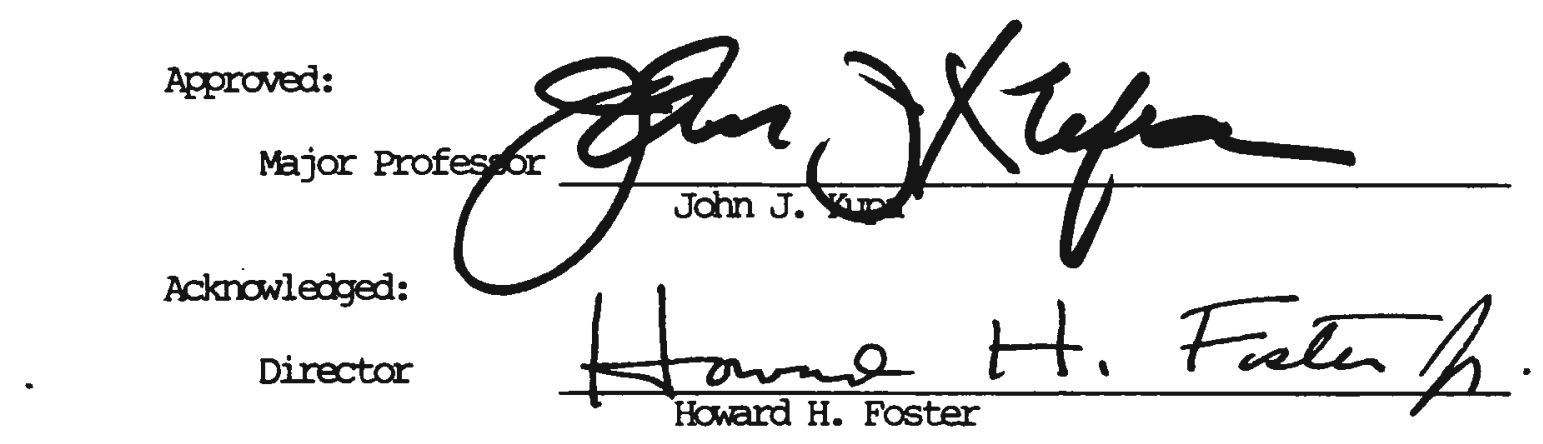




\section{Acknowledgements}

I would like to thank the numerous Rhode Island municipal and state officials without whom this project could not have been completed.

I would also like to thank Dr. John J. Kupa, my major professor, and Mr. Josepsh Lombardo, my outside advisor for the project, for their comments and constructive criticisms.

Iastly, I would like to thank my Mother, and Fiance' for their belief in me. Their strang support made it possible to complete the requirements of the degree program in two years time. 


\section{Table of contents}

Chapter \# Title Page \#

$1 \quad$ Introduction.............................. 1

2 Importance of Water........................4 4

3 Components of Water Quality....................13

4 Federal Water Quality Iegislation.................32

5 Rhode Island Laws and Agencies.................41

6 Recocmmendations/Canclusion...................66

6 Water quality comprehensive Plan................67

Appendix I RI Water Pollution Law

Bibliography 


\section{List of Figures}

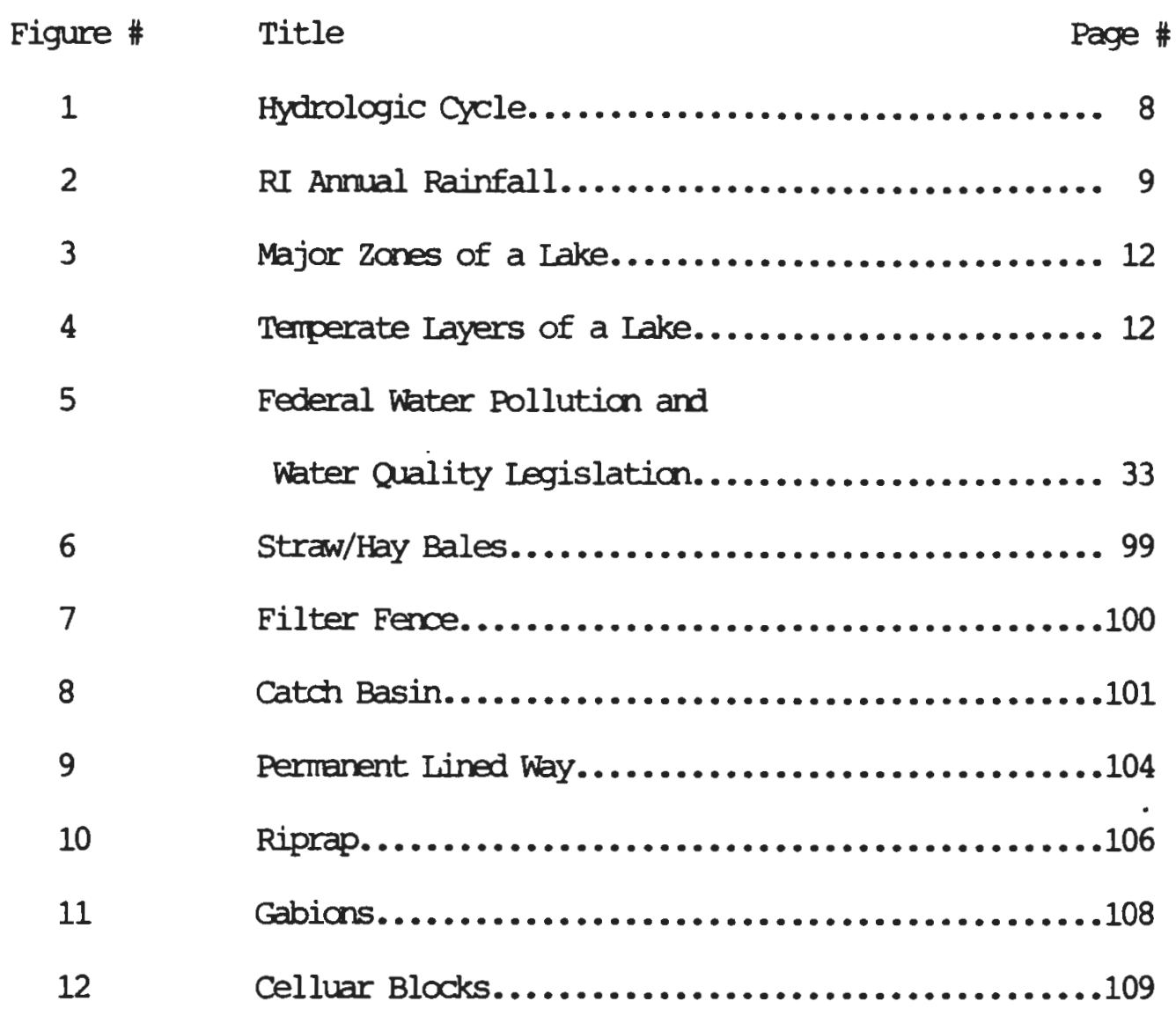


Chapter one

Introduction

Water is the chemical substance from which all life forms on earth evolved. Today it is still true that all life on earth depends upan and needs water; including human beings. The unique physiscal properties of water make it such a valuable substance to man and these physical properties create water's importance as a natural resource. The type of quality that water supports is what allows for or limits the growth of natural ecosystems and human populations. Water quality may often determine the quality of human lifestyles as well. The problems of maintaining water quality, the growing human population size and density, improving development technologies, and eliminating man-made pollution are all interrelated in Rhode Island. Water is necessary to grow food, to keep animals, to process minerals, metals, and energy resources, to dilute the waste produced by humans, and is required for hundreds of other human activities.

With the increasing human population demand, and the need to preserve the quality of water resources is a planning issue in Rhode Island. Rhode Island's concern for water quality protection is a reflection of the Nation's concern for envirommental protection and elimination of polluted water supplies. In response to this conoem, the federal government has acknowledged the need to regulate water quality by the passage of several important pieces of water pollution legislation: the Federal Water Pollution Control Act of 1972; the Safe 
Drinking Water Act of 1974; the Clean Water Act of 1977; and the Soil and Water Resources Conservation Act of 1977.

The State of Rhode Island has also passed important legislation dealing with water pollution and water quality standards. Several of the Rhode Island General Laws concern water quality, water supplies, their protection, and establish the Rhode Island State Agencies' authority to set water quality standards, to regulate and maintain them.

At the next level of government, the municipal level, however protection and control devices for water quality are lacking in the state of Rhode Island. The focus of this study will be on the legal options and planning alternatives availible to Rhode Island muicipal officials who are seeking to maintain and preserve local water quality in surface water supplies. In Phode Island municipal commuities, water quality is currently being impaired by street run-off, rum-off and drainage effluents from agricultural lands, sediment from eroded lands and construction activities, oily discharges, heated water discharges, discharges from boats, and a hundred of other non-point sources. Water quality is degraded by two sources: through point sources and non-point sources. Point sources occur where pollutants are discharged at a specific place and can be accurately measured. Non-point sources carmot be located or placed at one particular source. It is difficult to measure them accurately since many of them have irregular flows. Perhaps the largest non-point somrce of water quality degradation in Rhode Island's municipal commities is urban nunoff. 
Impaiments such as urban rumoff are growing in sheer magnitude, and presently in Rhode Island mmicipalities few of these impairments have not yet been satisfactorily controlled. Phode Island's municipal cormunties are experiencing both urban and nural development. The rapid rate at which development is occuring has brought an awareness about water quality and the availiblity of water supplies to the public's attention. Increased public pressure can not let municipal officials take the existence of high quality water for granted any more. Development will continue to follow the same traditional pattems unless local muicipalities adopt stranger controls to regulate how development proceeds.

This study will examine the extent to which water quality is regulated in Rhode Island. The effective management of water quality in Rhode Island commuities depends on the type of planning and decision making occurring right now. This study seeks to fumnish data on water quality and the legal controls existing in Rhode Island as well as mechanisms for the effective muicipal management of water quality in Rhode Island.

This study is organized into four chapters containing (1) a description of water's important physical properties, (2) a summary of some of the components of water quality, (3) a brief review of Federal water quality mandates along with a indepth discussion of Rhode Island General Laws concerning water quality, and a recormended plan containing devices for the control of loacl water quality. 
Chapter Two

Importance of water

Water is the earth's most important and versatile resource. It dissolves and transports nutrients from the soil to plants and animals, it dissolves and dilutes human wastes, it is a raw material for photosynthesis, and it is a major factor in climate and weather patterns (Chorley, 1979). Neither plants or animals can survive very long without it, and water is used in virtually every human activity.

Chemically water is an inorganic compond formed by the union of the elements oxygen and hydrogen (Leopold, 1974). Three states of matter exist on earth; solid, liquid, and gaseous. Water is the only substance that cocurrs naturally in all three states. The state which water is in depends upon its temperature. Water is so vital because its usefulness which stems from the following remarkable physical properties:

Water has a very high boiling point. Without this property, water would be a gas rather than liquid at normal temperatures (Beicos, 1967). If water did not have this property there would be no standing or moving bodies of water on earth.

Water has the highest heat of vaporization of all liquids (Beicos, 1967). This means that it takes a lot of energy to evaporate a given mass of liquid water. This is a major factor in distributing the sun's heat over the earth and in climate control. Water's high heat also helps to regulate the temperature of the human body by allowing the 
body to eliminate large amounts of heat by evaporating relatively small quanities of water (Beicos, 1967). This is one of the most important properties of water for humans.

Water has one of the highest capacities to store heat (heat capacity) of any known substance (Beicos, 1967). This means that a given amount of water has a very small increase in temperature when a specific amount of heat is added to it. Water cools slower than other substances because of this. This property of water prevents extreme climate changes, and helps protect living organisms from the shock of sudden abrupt temperature changes. And it is this property that is maximized when water is used for cooling in electrical power plants and industrial processes.

Water is less dense as a solid than as a liquid (Beicos, 1967). When most substances freeze, their volume decreases; thus, the density of the solid is higher than that of the liquid. In contrast, when water is cooled it expands and its density decreases. Without this property, ioe would not float on water. Bodies of water would freeze from the bottom up eliminating most aquatic life as we know it. This is one of water's most troublesame properties in that because water expands when it freezes it can break pipes, and cause cracks in streets, soil, and rocks. It often is the source of the infamous potholes scattered along Phode Island roads.

A final physical property worth mentioning is that water is unsurpassed as a solvent (Beicos, 1967). Water dissolves an incredible variety of substanoes. This enables water to carry nutrients throughout the bodies of plants, animals, and humans. It allows water 
to remove and dilute water-soluable wastes. Humans use this property to to remove much of their on wastes. This physical property is what contributes to the degradation of water quality. Because water dissolves so many things, it is also easily polluted or the quality of the water changed (Leopold, 1974).

All of these physical properties allow water to by used by man as it is being used today. If any of these properties were different then water would be a different substance and not as useful to man. one must realize how valuable water really is to man, especially since the total supply of fresh surface water in all forms is fixed. This means that due to the constrainsts of the hydrologic cycle, man can not easliy produce more fresh water if current supplies become so degraded that they can no longer be used.

Hydrologic Cycle

The hydrologic cyle refers to the never ending process by which water changes its physical state and its location on or within the earth's surface. This cycle provides for continous freshwater supplies and affords a natural filtration and purification scheme. Bodies of water undergo evaporation constantly when they come into cantact with the air. Water is being exchanged between the earth and the atmosphere all the time through evaporation. This exchange is accomplished by the heat of the sun and the pull of the earth's gravity. Water evaporates fram many surfaces including wet ground, the wet leaves of plants, and from the surface of water bodies. In doing so a certain amount of 
water changes from a liquid state to a gaseous state and becomes part of the atmosphere. The water vapor in the air will eventually condense into water droplets and fall back to earth in the varying forms of precipitation including rain, sleet, hail, or a mixture of these (see figure 1). This exchange goes on constantly around us. Rhode Island has an average rainfall of fourty-four inches per year in its hydrologic cycle (see figure 2).

Human beings are most concerned with the standing fresh water part of the hydrologic cycle. This study is concerned with fresh water on the land sunface; the surface water visible in lakes, pands, rivers, brooks, and streams. The well being of human cammunities, both urban and rural, is highly dependent on the water availible for their daily needs. Natural ecosystems need water as well. Water pollution can have devastating effects on organisms, populations, and fresh water ecosytems

\section{Fresh Water Eoosystems}

Fresh water ecosystems can be classified as lotic (flowing) and lentic (standing water) systems. Because of differences in the rate of water movement rivers and lakes differ considerably in their ecosystem structures and water pollution problems (Stoker \& Spencer, 1976). Because they flow, most rivers can recover fairly fast from pollution. The time and distance a moving body of water takes to recover from the effects of pollution depends on the river's volume, flow rate, and the amount of the pollutant load. By dilution, a moving water body can 


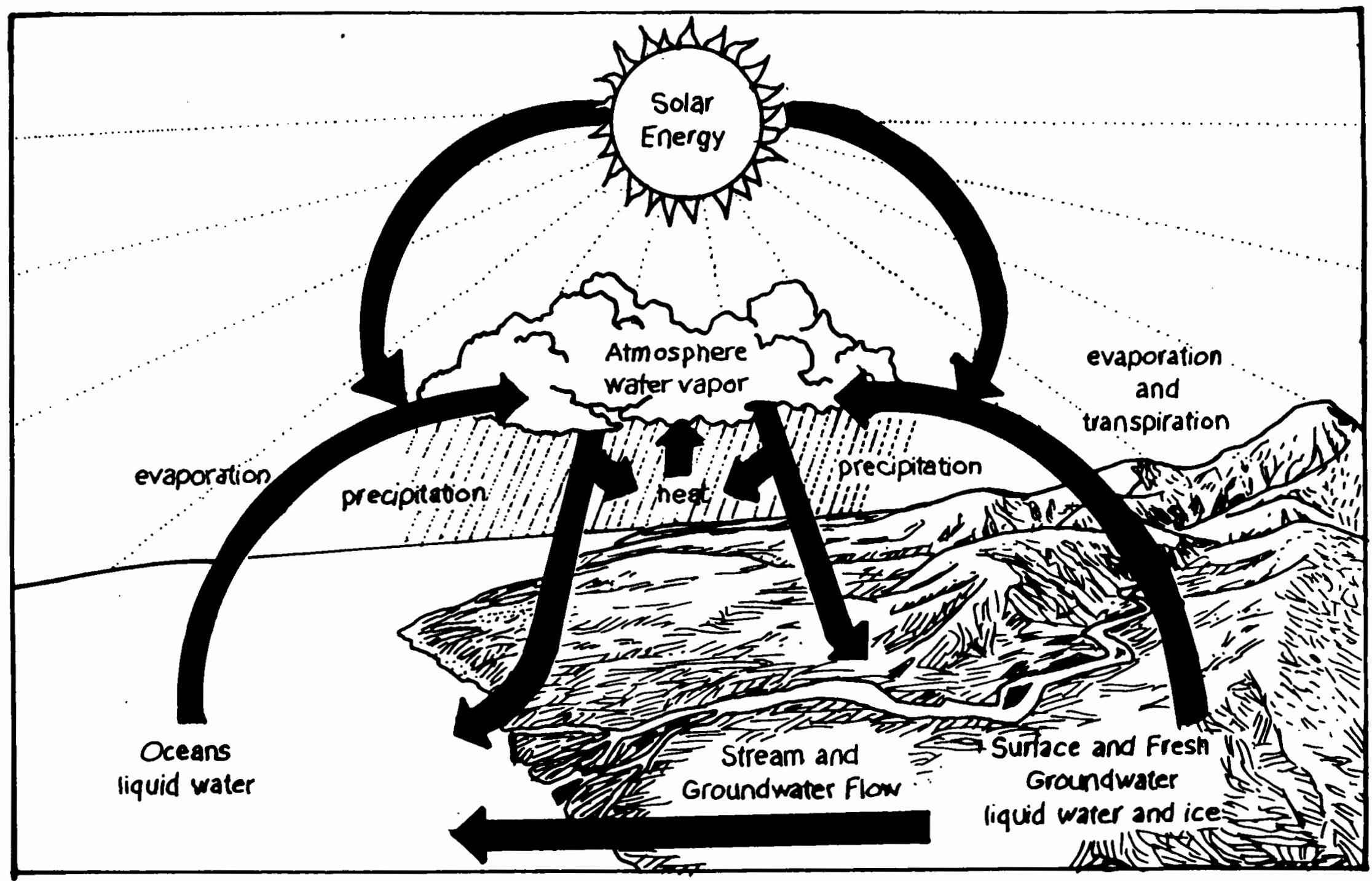

THE HYDROLOGIC CYCLE 
effectively treat heat, oxygen demanding wastes, and short lived toxic chemicals; but only if the flow is adequate and the water body is not overloaded with the pollutants. This is an example of natural chemical cycling. However, long lived chemicals cannot be easily assimulated. Preventing the degradation of water quality in a moving body of water must be done along its entire length; not at just a few points along the river.

In contrast to moving bodies of water standing water ecosystems, such as lakes and ponds, have relatively little flow. The flushing time of a river may be measured in days, but renewal in lakes may take decades to hundreds of years (Stoker \& Spencer, 1976). Lakes and ponds have three distinct zones (figure 3). The littorial zone is the area closest to shore and is the zone in which rooted aquatic plants are found. The limnetic zone is the open water surface area through which sunlight can penetrate. The profundal zone is the deep water which sunlight cannot reach (Coker 1968).

In Rhode Island, standing bodies of water have layers of water with different temperatures during the summer and the winter. In the summer the surface water is heated by the sun to form an upper warm layer called the epilimnion which floats over a layer of cold water called the hypolimion. These two layers are seperated by a thin layer called the thermocline in which the temperature drops swiftly (Figure 4). Because of minimal water movement, standing water bodies are even more susceptable to water quality degradtion and pollution problems. The major pollution problem of standing water bodies is accelerated eutrophication by nitrates and phophates from human activities. A lake 
with an excessive amount of plant nutrients is called eutrophic. A lake with a low supply of nutrients is called an oligotrophic lake. All lakes undergo natural eutrophication but many of the activities preformed by humans accelerate this process and degrade the water quality as a result. 
Figure 3

Major Zones of a Lake

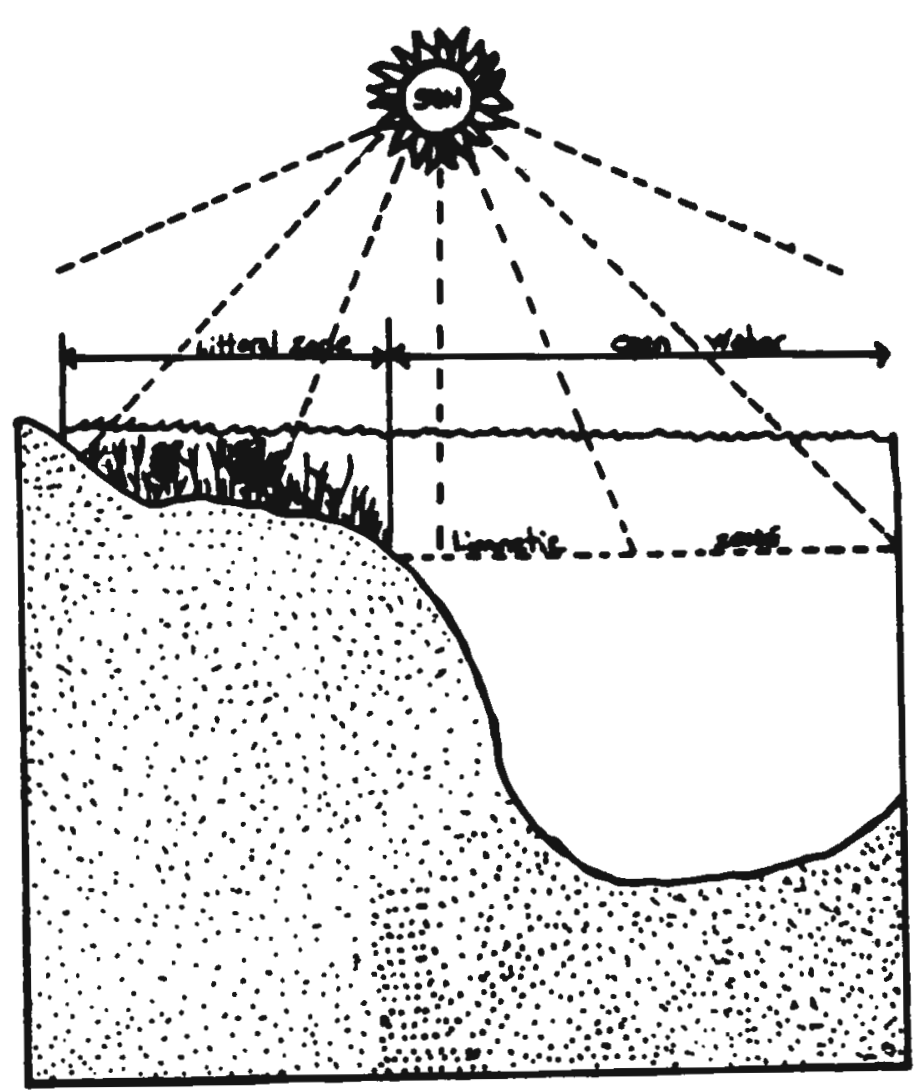

Figure 4

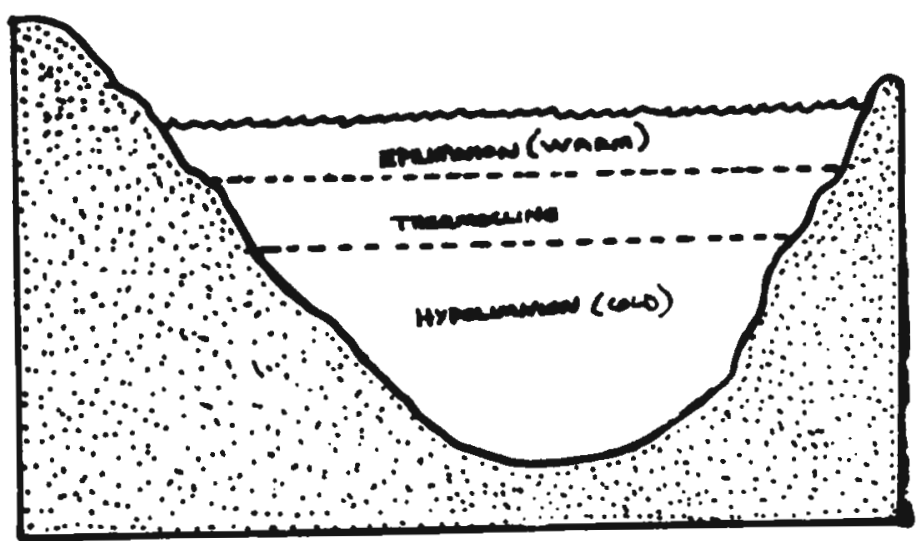

Temperate Layers of a Lake 
Chapter Three

Water Pollution

The very nature of surface water supplies and aquatic ecosystems and their many possible uses contribute to the problems of water pollution. In aquatic ecosystems water is seldom perfectly pure. In some instanoes natural factors can cause water pollution and affect water quality but the major causes of these problems arise as a result of human activities. Water pollution is found in many forms. The term pollution, according to the Rhode Island General Laws, means the man-made or man-induced alteration of the chemical, physical, biological, and radiological integrity of water. Water pollution cocurs when some substance or condition (such as heat) degrades a body of water to such a degree that the water does not meet specified standards or cannot be used for a specific purpose. Thus water quality depends not only on water in its natural state, the nature of pollutant loads, and the intended uses of the water. Pollution of surface waters comes from point and nompoint sources as previously mentioned. Both forms of pollutants can make water unsafe for many uses. Pollution does not reduce the amount of surface water availible. It makes many uses of water more expensive because treatment of the water is required to raise the quality of the water until it can meet the standard for the desired use.

\section{Water Quality Standards}

A water quality standard defines the water quality goals of a water body by designating the use or uses to be made of the water. The water 
quality standard sets criteria necessary to protect the desired uses. Water quality components and criteria will be discussed later in this chapter.

According to the Rhode Island Department of Environmental Management (DEM), the intention behind water quality standards are to protect the public health and welfare by enhancing the quality of water, and to fufill the requirements of the federal Clean water Act and Chapter 46-12 of the General laws of Rhode Island (both of these laws are discussed in the next two chapters). The purposes of water quality standards are to protect and provide for the propagation of fish, shellfish, and wildlife dependent on water, to provide recreation connected with water bodies, to protect public water supplies from pollution, and allow agricultural, incustrial, navigation and other uses of water. Water quality standards set by DEM define goals for a particular water body. They serve as the regulatory basis for the establishment of water-quality-based-treatment controls and strategies that expand upon the technology-based levels set out by the Clean Water Act (DEM water quality Regulations, see Appendix A).

Rhode Island Water Quality Classifications

Based on these reasons, all of the surface waters of Rhode Island have been categorized by DEM into classes. Each seperate class is so designated to differentiate among the various demands each type of water use has. Water quality criteria serve as the basis for determining different classes of water and define the parameters that must be met for each class of water. (Differing components of water 
quality and their criteria will be discussed later in this chapter.) Fach class of water has been defined by DEM to be limited by the most sensitive use. It is this most senistive use for which the class is designed to protect. The following is a descriptive list of the classes of surface water taken from the DEM water quality standands in use:

Freshwater-

Class A - Drinking water supply only

Class B - Public water supply with treatment

- Agricultural uses

- Bathing, other primary contact recreational activities

- Fish and Wildlife habitat

Class C - Boating, other secondary contact recreational activities

- Fish and wildlife habitat

- Industrial processes and cooling

Class D - Migration of Fish

- Good asthetic value

Class E - Nuisance conditions; uses limtited to:

- Certain industrial processes and cooling

- Power

- Navigation

Seawater-

Class SA - Bathing and contact recreation 
- Shellfish harvesting for direct human consumption

- Fish and wildlife habitat

Class SB - Shellfish harvesting for human consumption after durpuration

- Bathing, other primary contact recreational activities

- Fish and Wildlife habitat

Class SC - Boating, other secondary recreational activities

- Fish and wildlife habitat

- Industrial coling

- Good asthetic value

\section{Water Quality Criteria}

Water quality criteria are used to support the above classes. Water quality criteria are used to protect surface waters from pollution and to protect the existing qualities of the State's waters for the public's health, safety, and welfare. Water quality criteria specify concentrations of water constituents, which if are not exceeded, will result in aquatic ecosystems for designated uses of water. The base of scientific knowledge for water quality criteria has been done by the United States Environmental Protection Agency (EPA) under the mandates of the federal Safe Drinking water Act (discussed in the next chapter). EPA says that water quality criteria are not intended to offer the same conditions for survival to all aquatic 
organisms within given ecosystems. Water quality criteria protect the aquatic lifeforms dependent on water, those organisims that consume aquatic organisms, and those organisms that directly use water such as human beings (EPA Water Quality Criteria, 1976) .

Aquatic organisms are diverse and respond differently to identical stimuli. Aquatic organisms do not exhibit the same degree of harm, individually or in species, from a given conoentration of a toxicant or potential toxicant within the enviromment. Water quality criterion exist to protect the most sensitive species which are vital to the proper functioning of the natural ecosystem. Water quality criterion have identified parameters that provide a measure of safety for these vital species. In aquatic ecosystems, the food chain is a complex relationship of predator and prey. A water pollutant that might eliminate an important organism in this food chain could destroy or seriously impair the other aquatic organisms dependent upon it. Bioaccumulation of man-made and natural toxic materials in food chains is a well documentated fact (Haynes, 1963). Intial toxicant levels, if not immediately toxic and damaging, may accumulate in the biotas or sediment and increase to levels that are lethal to aquatic organisms or those organisms that consume them such as human beings. Water quality criteria reflect a knowledge of the capacity for environmental accumulation, persistence, and effects of specific toxicants in specific aquatic systems.

EPA's data on water quality criteria deal with specific constituents of the aquatic enviromment. The purpose of the criterion is to ensure that more than one water use would be possible. EPA's 
criteria are meant to protect not only the aquatic environment but to protect man's health and safety as well. I have selected from the many components of water quality the components that are commanly associated with water quality problems in Rhode Island. EPA's criterion for each component is presented with a brief introduction about the particular substanoe, comman examples are given, and EPA's criterion for each substance is given (EPA Water Quality Criteria, 1976) follow here:

EPA Water Quality Criterion:

Alkalinity- Alkalinity is the sum of total components in the water that tend to elevate the pH of the water above a 4.5 value. It is a measure of the buffering capacity of water. Alkalinity is important for fish and other aquatic life in freshwater systems because it buffers pH changes that ocur naturally as a result of photosynthetic activity of vegetation.

Excessive alkalinity can cause problems for swimmers by altering the pH of the lacrimal fluid around the eye, resulting in irritation. Alkalinity can also affect food production when the specific food depends on flavor and stability such as carbonated beverages do.

Examples of commonly occurring materials in natural waters that increase the alkalinity are carbonates, bicarbonates, phospates, and hydroxides.

EPA Criteria: $20 \mathrm{mg} / \mathrm{l}$ except where natural concentrations are less.

Color- Color in aquatic systems results from degradation processes. 
Color in water is an important constituent in terms of asthetic considerations. To be asthetically pleasing water should be free of any induced color fram man. No general agreement exists on the color of water in its natural state. The asthetics of water's color depends upon one's view of the water setting.

The effects of color in water on aquatic life principally are to reduce light penetration which in turn recuoes photosynthesis and restricts the zone for aquatic plant growth.

Dissolved iron and manganese ocassionaly cause color in water. Organic compounds originating from the decomposition of organic matter cause color in water. Industrial discharges suxh as paper pulp, tanning, plastic, and chemical discharges may cause color in water.

EPA Criteria: (1) Waters shall not contain substances that produce unwanted colors for asthetics

(2) Increased color should not reduce the depth of the campensation point for photosynthetic activity by more than 10 percent from the seasonably eastablished norm for aquatic life.

Fecal Coliform Bacteria- These are bacteria present in human wastes and can enter water at the microbiological level. Microbacterial indicators are used to determine the safety of water for drinking, swimming, and shellfish harvesting. Bacteria of the coliform group are considered the primary indicators of fecal contamination for water quality. Coliform bacteria are bacteria associated with the wastes of wamblooded animals. These bacteria are used as criterion becuase they 
multiply anly in wamblooded animal's intestines and not in water such as other type as bacteria due.

pollution of aquatic ecosystems by the waste products of human beings poses health problems not only for man, animals, but aquatic organisms as well. The presence of fecal coliform bacteria has the potential to infect man. The presence of such bacteria is considered by EPA to be indicative of the degree of health risk in using waters containing such bacteria.

Disease transmission by ingesting polluted water or polluted organisms from polluted water could be a problem in Rhode Island. one of the greatest threat is to swimmers. Diseases associated with heavily ingested waters are typhiod and salmonella. Another threat that these bacteria pose to humans is in shellfish. Rhode Island has a large shellfish industry. Shellfish are the filter feeders of the aquatic enviroment. Shellfish exist by siphoning nutrients from the water in which they are located. Because of this, pollutants become concentrated in shellfish and remain there for some time. once shellfish waters are polluted and the pollution source renoved, the concentration takes a long time to flush from the body of each shellfish.

EPA criteria: Swinming waters- Fecal colifonm bacteria should not exceed a log mean of 200 per $100 \mathrm{ml}$. Shellfish harvesting waters- the medium fecal coliform bacteria should not exceed 14 MPN per 100 ml. 
Hardness- Water hardness is caused by the dilution of metallic ions. In fresh water these ions include calcium, magnesium, iron, strantium, and maganese. Hardness is commonly reported as an equivalent concentration of calcium carbonate. Hardness can be easily shown by the amount of soap required for adequate lather formation. A natural source of hardness is rainwater dissolving limestane. Industrial sources include the chemical industry and in certain areas discharges from operating and abandoned mines. Hardness can be used in determining the total dissolved solids present in water. Exoessive hardness in water can be removed through lime-soda softening or ion exchange systems. These methods are feasible for public water supplies but would be expensive for individual homeowners.

EPA Classification of water by hardness content-

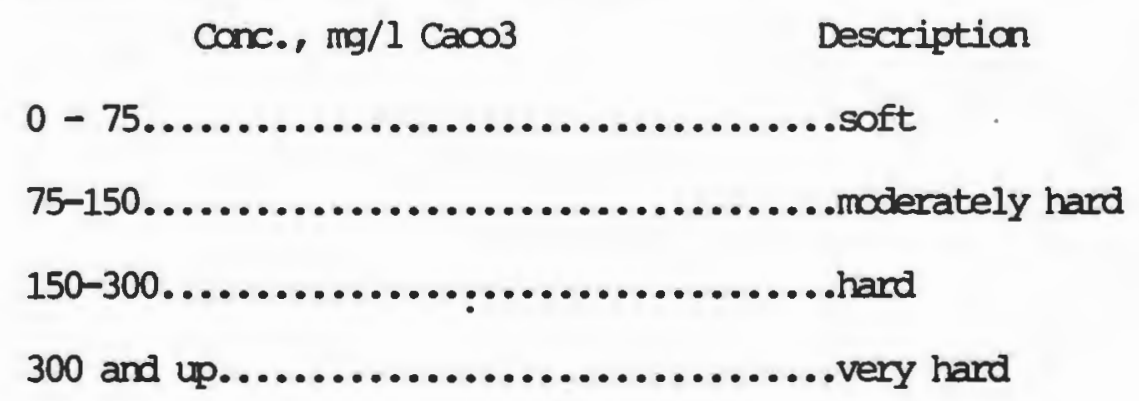

Nitrates, Nitrites- In axygenated natural water systems nitrate is rapidly oxidized to nitrite. Growing plants asimulate nitrate and convert it into protein. High conoentrations can stimuate excessive plant growth in water bodies. This situation is called eutrophication. Major point sarroes of nitrogen pollution in water bodies are municipal and industrial wastewaters, septic tanks, and feedlot discharges. Non-point sources include, but are not limited to, farm-site 
fertilizers, animal wastes, lawn fertilizers, leachate from sanitary landfills, atmospheric fallout, nitric oxide, and nitrite discharges from automobiles.

In natural quanities normally found in water ecosystems, nitrates become toxic when they are recuced or may be reduced to nitrites. Under certain conditions, nitrate can be reduced to nitrite in the gastrointestinal tract and then reaches the bloodstream and reacts directly with hemoglabin to produce methemoglobin, which impairs the transportation of oxygen in the blood. This is especially hazardous to infants under three months of age. Serious or fatal poisoning can result in such young infants after the ingestion of untreated well waters. This danger exists in shallow farm and cormunity wells, often as the result of inadequate protection from septic tanks or agricultural nmoff.

Fish are often susceptable to nitrogen poisoning as well. Salmon breeds are most susceptable to high concentrations of nitrites in water. Trout species are the next sensitive species with nitrogen levels that must be lower than other fresh water fishes. Fish can suffer also from the excessive plant growth nitrogen can cause. Excessive plant growth can cause axygen depletion, temperature changes, organic matter build up, and fish kills.

EPA Criteria- $10 \mathrm{mg} / \mathrm{l}$ nitrate nitrogen (N) for domestic water supply.

Oil and Grease- A oil or grease can be one of a thousand organic compounds. Such organic compounds have varying physical, chemical, and 
toxic properties. They may be volatile or not, soluble or not, persistent or easily degraded. Oils and greases can enter water bodies and accumulate there. These substances attach to suspended solids for transportation into water bodies. Urban nunoff from highways and improperly disposed of waste oils fram automobiles are the heaviest contributor from this substance group. Oils, greases, and petroleum products can be found at four levels of the aquatic enviranment: (a) floating on the surface, (b) emulsified in the water column, (c) solubilized, and (d) settled on the bottom as a sludge.

During the 1960's many major oil spills in the United States brought oil pollution to the attention of the nation. These spills were large and many aquatic and water dependent fonms of wildlife were killed demanstrating the sensitivity of aquatic ecosystems. Most aquatic organisms are intolerant of petroleum based products. The long term sublethal effects of oil pollution include interferences with celluar and physiological procoesses such as feeding and reproduction. Bicaccumulation of petroleum products has two public health problems: (1) the tainting of edible, aquatic species, and (2) the possibility of such species incorporating in their tissues carcinogenics. Because natural systems take lang times to process petroleum products, the time lags fram pollution to biodegradation are lang and the products remain persistent in the sediment layers. Oils, greases, and petroleum products can form a sheen, film, or discoloration on the surface of the water. Oils of any kind can cause the following to:

Water Fowl-drowning due to loss of buoyancy and exposure because of loss of insulating capacity of their 
feathers, starvation and vulnerablitiy to predators

from lack of mability.

Fish- lethal effects by coating outer surfaces of gills and preventing respiration, potential fishkills due to increased biochemical oxygen demand, asphyxiation of bottam dwellers when surface debris and sediments accumulate.

Asthetics- adverse aesthetic effects of fouled shorelines and beaches.

EPA criteria- Because of the many diferring toxic properties of oil EPA has set different levels for domestic supplies and aquatic organisms.

Domestic- Free from all oil and grease, especially from tastes and ordors that result from petroleum products.

Aquatic Life- Individual petrochenicals should not exced 0.01 of the lowest continuous flow 96-hour IC50 to important freshwater or marine species. Accumulations in the sediments of water bodies not allowed. Surface waters fre from floating oils. 
Dissolved axygen- Dissolved axygen concentrations are an important gauage of existing water quality and the ability of a water body to support various aquatic organisms. Insufficient dissolved oxygen causes the anaerobic decomposition of organic matter. This anaercobic decomposition causes the formation of noxious gases such as hydrogen sulfide and the development of cardon dioxide and methane (swamp gas) in the sediments which bubble to the surface. Dissolved oxygen prevents leaching of chemicals fram the bottom sediments.

Fish vary in their oxygen requirements according to species, age, activity, temperature; and nutritional state. Dissolved axygen criteria that will maintain a well rounded fish population in terms of species must be maintained. Fish populations are composed of different but interdependent species of varying feeding and reproduction habits. The most sensitive species of the population should determine the demand for dissolved axygen. A dissolved axygen concentration of $5 \mathrm{mg} / \mathrm{l}$ will support a well rounded population as well as some game fish. Reproctuction of the fish population can be affected by low dissolved oxygen as well. Without the proper amount of axygen the enbryos will not develop. Decreased axygen levels can also affect aquatic insects and other animals upon which fish feed. EPA has found that most aquatic life can be sustained by maintaining the dissolved oxygen levels suitable for fish.

The dissadvantage of substantial quanities of dissolved oxygen in water, when used a source of drinking water is; that dissolved axygen may increase the rate of corrosion in metal pipes. This would add iran, copper and other metals to drinking water which may cause taste in the water as 
well as disooloration from stains.

EPA Criteria- Asthetics: Water should have enough dissolved

oxygen to maintain aerobic conditions except where

natural phenomena change such conditions.

Fresh Water Aquatic Life- Minimum concentration

of dissolved axygen for well rounded fish populations is $5 \mathrm{mg} / \mathrm{l}$.

pH (Acidity) - "pH" is a measure of the hydrogen ion activity in water. The prinicipal system of regulating pH in natural waters is the carbonate system. pH is an important factor in the chemical and biological systems of water bodies. The degree to which waters are acidic or basic is determined by pH. Various chemicals and gases become more or less toxic at higher or lower pH levels. pH levels determine in part what becomes released from the sediments of the bottom of water bodies. The ph of water also determines what buffering capacity water will have. This buffering is how much that the water can absorb before a change is determined. Buffering is controlled by the alkalinity (previuously discussed) and the acidity (discussed later) a water body supports.

Knowledge of $\mathrm{pH}$ is important to understand the corrosive potentials of water. Corrosion of pipes and deliviery systems carrying water can lead to metal ions such as copper, lead, zinc, iran, and other metals to be present in water. pH is measured on a numerical scale with 7 being neutral. Maintaining a level of 7 generally will prevent conroding of water transmission piping. 
Fish have problems reproducing in waters where the $\mathrm{pH}$ on the lower end of the scale in acidic waters.

\title{
EPA PH critieria-
}

\author{
Range \\ $5 \quad-9 \quad$ Domestic water supplies \\ $6.5-9.0$ Freshwater aquatic life \\ 6.5 - 8.5 Marine aquatic life
}

Phosphonus- In elemental form phosphorus is extremely toxic and subject to bioaccumulation. In freshwater ecosystems, phosphonus is essential for plant nutrition. As stated before, excess amounts of phosphorus stimulate acoelerated plant growth. This is called eutrophication. Of all the limiting elements in aquatic ecosystems phosphonus is the one most easily controlled by man. Phosphates enter water bodies from many of man's activities. Human beings excrete phospates in their wastes, and use phosphates in laundry detergent. Phosphate not taken up by plants finds its into the sediments of the bottom and are stored. They became availible for future use this way, perhaps causing eutrophication problems much later then their intial entrance to the water body. This phosphate can become fixed and would be expensive to remove. Another problem of excessive eutrophication is the growth of noxious plants that crowd out the food plants and habitat plants. These noxious plants can also crowd out fish and wildlife by competing for oxygen and space in the water body. 
The amount of nutrients that will be retained by a water body is dependent upon the nutrient loading to the water body, the extent of biological activities, the volume of the eutrophic zone, the rate of flow within the water body, and the time flow of the biological activities taking place in the water body. All these factors detemine if the water body is eutrophic or not and if the phosphorus entering it is needed or is a pollutant.

$$
\text { EPA criteria- } 0.10 \mathrm{ug} / 1 \text { yellow phosphorus. }
$$

Dissolved Solids and Salinity- Dissolved solids are generally inorganic salts, dissolved materials, and small organic particules. Salinity is the amount of dissolved salt present in water. Excessive dissolved solids in drinking water is undesirable because of corrosion, undesirable tastes, and effects on the human metabolism. Persons on restricted sodium diets can be harmed. People with cardiac problems and women with toxemia from pregancy are in danger from the sodium levels of waters with high amounts of dissolved solids. Dissolved solids can corrode surfaces and encrust surfaces with sediments. Household water systems can be affected by - corroded and clogged water pipes, and wastewater pipes.

Aquatic life and fish live with some dissolved solids in natiral conditions. Dissolved solids can limit fish populations and cause a lowering of the dissolved axygen present. Many freshwater fish cannot tolerate severe changes in salnity as marine fish can. Game binds are susceptable to salinity changes as well; young birds are susceptable to poisoning at high salinity levels. Too many dissolved solids can eliminate 
food plants and habitat-forming plants for such birds.

EPA criteria- $250 \mathrm{mg} / 1$ for chlorides and sulfates in drinking water supplies.

Suspended Solids and Turbidity- Suspended solids are organic and inorganic matter in water. Suspended solids are health conoerns in public water supplies as the solids provide surfaces for harmful bacteria to cling to and escape removal. Suspended solids create the turbidity of water bodies. They reduce the clarity of water, limit the amount and depth of sunlight penetration reducing the photic zone, and in excessive amounts change the color of water. The more turbid the water, the more suspended solids are present. Turbid waters decrease recreational uses of water for many reasons. It is not asthetically pleasing to swim in such waters and turbid waters carry dangerous bacteria which may cause disease.

Suspended solids affect fish populations also. Sedimentation accumulation on the bottom of water bodies can suffocate bottam dwellers. Dissolved oxygen levels can be depleted causing fishkills, lowered growth rates, and hampered reprocuction rates. Suspended solids can block streams and rivers important to mitragrating species and limit movements.

EPA criteria- Freshwater fish and other aquatic life: Suspended and settlable solids should not reduce the depth of the compensation point for photosynthetic activity by more than 10 percent from the seasanally established norm for aquatic life.

Tainting Substances- Tainting substanoes are substances that will produce an undesirable taste in either the water itself or an edible 
aquatic lifeform. Fish or shellfish that have unusual ordors, colors, or tastes are not acoeptable. This is usually thought of as inferior products and can seriously hurt the commerical fishing and shellfish harvesting industries in Rhode Island. Industrial wastewaters contain many sustances such as cresol and phenol compounds, kerosene, napthtol, and tolvene. The extaust of motor boats may even contribute to the tainting of certain aquatic sepecies. The susceptability of aquatic organisms to tainting depends upon the species, the pollutant, and the length of exposure.

EPA criteria- Materials should not be present in concentrations that individually or in combinations procuce undesirable flavors which are detectable in the edible portions of aquatic organisms.

Temperature- Man's use of water is enterly dependent upon the temperature of water. As stated before, the state of matter that water is in depends upon its temperature. So is aquatic life regulated by the temperature of water. Aquatic organisms are coldblooded, therefore the temperature of water regulates the temperature of their bodies. The human body is also concemed with water's temperature. You cannot stick your hand into water which has to high of a temperature. Swimming is regulated by temperature. Extreme exposures to cold artic water can kill. Extreme exposure to boiling water can burn.

In natural eoosysterns, temperature helps regulate the biological activities being carried out. It limits the amount of dissolved oxygen that can be present. Hot waters have lower levels of dissolved oxygen than colder waters. Oxygen is less soluble when temperature increases. ToO high a temperature may cause septic and noxious conditions. Lower and 
upper temperature limits have been established for aquatic organisms. Exceding either one of these parameters will result in death for a particular organism. This is a result of the genetic quality of each species and is different for each species. To maintain sensitive species the water temperature parameters must be kept for that particular species.

Man-made changes of temperature, such as heated industrial discharges, may permanently alter the species population of water bodies. If a key species is eliminated the whole comminity could suffer.

\section{EPA criteria-}

* (EPA has complex logrithmetic and tabular methods for calculating water temperature criteria that are far beyond the soope of this study to include here therefore, some general principals of the methodolgy are presented for general knowledge.)

EPA standards- Temperature limits for a body of water must be set for the most sensitive species of that water body. Temperature limits will vary with the season of the year and with the type of water use. The ambient temperature of a water body should be maintained at what is nomally found at that location and time. Reproductive seasons should have more temperature constraints. Site specigic standards shall be imposed for reproductive functions of important species and to preserve normal species density. Temperature shall be maintained to prevent the appearence of nuisance organisms. 
Chapter Four

Federal Water Quality Legislation

This chapter deals with the history of the United State's federal legislation to regulate water pollution and water quality. The chapter deals with the major acts passed into Public Law dating from 1886 until the present. Each federal statute is introduced, and a brief symopsis of the major issues of each statute is presented. The statutes appear in chronolgical order and Figure 5 shows the order of the statutes. Water quality legislation at the federal level dates back to the nineteenth century when Congress enacted the Rivers and Harbors Act of 1886, reoodified in the Rivers and Harbors Act of 1899. The Act prohibits obstructions to navigation and the dumping of any refuse into navigatable waters. The intent of the Act was to prevent interference with navigation. To discharge into such waters a permit was required from the US Army Corps of Engineers. Pollution control was an independent goal of the statute.

The first water pollution control statute knowingly enacted by Congress was the Oil Pollution Act of 1924, 43 Stat., 604. The Act was designed to control oil discharges into coastal waters. The Act made it unlawful except for unavoidable accidents, to discharge oil into waters within the ebb and flow of the tide.

After World War II, Congress passed the Water Pollution Control Act of 1948 (Public Law 845). This act was the first step towards a comprehensive water pollution control policy (Reeves, 1984). The Act provided for federal research into water pollution control strategies. 
Figure 5

Federal Water Pollution and Water Quality legislation

1899 The Rivers and Harbors Act

1924 The Oil Pollution Act

1948 The water Pollution Control Act

1956 The Water Pollution Control Act Amendments

1961 The Water Pollution Control Act Amendments

1965 The Water Quality Act

1966 The Clean Water Restoration Act

1970 The Water Quality Improvement Act

1972 The Federal water Pollution Control Act Amendments

1974 The Safe Drinking water Act

1977 The Clean Water Act

1977 The Soil and Water Rescurces Act

1986 The Water Resources Development Act 
22.5 million dollars in federal grants were also provided to support state and local water pollution control programs. Limited federal loans were also provided to help construct municipal wastewater plants. Interstate anti-water pollution compacts were encouraged.

In 1956, Congress first amended the Act (P.L 660). The amended Act was adninistered by the Surgeon General of the Public Health Service under the supervision and direction of the Secretary of Health, Education, and Welfare. The most important provisions of the amendment were to affirm Congress'es intent to control water pollution, to provide technical assistance to states to increase research, to encourage more interstate water pollution compacts, appointment of a Water Pollution Control Advisory Board, and establish a program to control pollution from federal installations.

In 1961, the Water Pollution Control Act was amended again (P.L. 87-88). These amendments improved and strengthened the Act in the following areas; it designated the Secreatary of Health, Etucation, and Welfare to administer the Act, authorized the concept of storage to regulate stream flows for quality controls, called for more water resources research, increased the amount of maney for the construction of municipal wastewater treatment plants, and extended federal authority to be able to enforce the interstate water pollution compacts it had been encouraging. The 1961 amendments affimmed the responsibility of states to regulate and control water pollution. The federal function was to work with the states and coordinate efforts among varying sectors of society.

The Federal water Quality Act was passed by Congress in 1965 (P.L. 
89-234). This Act created a new agency to administer water pollution, the Federal Water pollution Control Administration (EWPCA). The concept of water quality standards was introduced for the first time. The Act required that States adopt water quality criteria together with a plan for implementation and enforcement. The secretary of the FWPCA would review these plans and decide if they fufilled the proposals of the Act.

In 1966, the Clean Waters Restoration Act was passed (P.L. 89-753). This Act recognized that water pollution control must be comprehensive in nature. It authorized grants to set up planning agencies to develop effective water quality control and abatement plans on a river basin basis. These plans were to incorporate the water quality standards determined by the 1965 water quality Act. This Act also provided more grants for water resources research to state and local agencies and private individuals. This Act allocated the largest grants yet for waste treatment plant construction and set quality standards for water receiving sewage treatment plant discharges.

A major oil spill off the coast of California, capled with increasing awareness and concem with americans about the enviroment, led to the passage of the 1970 Water Quality Improvement Act (Kamieniecki, 1980). The 1970 bill authorized the federal government to cleanup oil spills that jeopardize coastal waters, and made the polluter liable for up to fourteen million dollars of the cleanup costs. Responsibility for the regulation of oil spills was given to the newly created Environmental Protection Agency (EPA). The Act also placed controls on sewage discharged by vessals, and strengthened the 
federal govermment's authority to regulate offshore oil drilling.

In 1972 Congress passed amendments to the Water Pollution Act that overwsote all of the previous statutes dealing with the regulation of water pollution and water quality. The 1972 legislation (P.L 92-500) initiated a major change in the basic approach to water pollution control by limiting effluent discharges and setting national water quality standards (Kamieniecki, 1980). The primary objective of the Act was to restore, and maintain the chemical, physical, and biological integrity of the nation's waters. Specific objectives of the Act are; discharges of pollutants into navigatable waters would be eliminated by 1985, establish and reach water quality goals to protect fish, shellfish, and wildlife and to provide recreation in and on waters by 1983, to prevent the discharge of toxic discharges, provide federal assistance to publically owned waste treatment works, to develop areawide waste management planning processes, and finally to encourage reasearch and technicalogical efforts to eliminate the discharge of pollutants into navigatable waters.

The federal grants availible for the construction of municipal waste water plants were increased. For the purposes of muicipal treatment improvement, up to $\$ 18$ billion was authorized to be made availible for fiscal years 1973 through 1975.

The basic regulatory requirement of the Act was the establishment of the National pollutant Discharge Elimination System (NPDES) for all public and private pollutors. In Rhode Island, the Department of Enviromental Management (DEM) administers the NPDES permit system. Penmits are issued to comply with specific effluent guidelines issued 
by the EPA. BY 1977 industrial facilities were to establish the best practicle control technology (BPT), to limit pollution from discharges, and by 1977 to use the best availible technology economically availible (BAT). The Act also required the Administrator of the EPA to publish a list of toxic pollutants and effluent limitations or prohibitions of their discharge. Toxic pollutants are defined by the Act to be those which when assimulated by the enviroment either directly or indirectly, will cause death, disease, behavioral abnomalities, cancer, genetic mutions, physiological malfunctions, or physical defonmities in any organisms or its offspring.

Under the Act, all States were required to develop a comprehensive and continuing planning process for water quality management. Section 208 of the Act required the plans to include controls for point sources, diffuse land runoff, and other nompoint soumces. (A part of the next chapter will discuss how Rhode Island has set about fufilling the requirements of Section 208.)

Enforcement under the Act was simplified. The Act made it unlawful to discharge pollutants fram point sources unless a permit had been issued. The EPA was given the authority to enforce the law through either administrative channels or judicial ones. The EPA Administrator has the power to issue an administrative order against further violation or he may request the Attorney General to seek relief in federal court. Private citizens can seek injunctions against pollutors for violating effluent limiations or EPA orders. Private citizens can also sue the EPA Administrator should he fail to preform his duties as required by this Act. 
In passing the Safe Drinking Water Act of 1974, Congress tried to meet the problem of both surface and groundwater quality by calling for the setting and policing of national standards. It was left to state and local governments and to private water companies to provide the expenditures necessary to raise existing quality levels of cammity and urtan systems to the required levels. The Act required EPA to set standards for chemicals found in drinking water.

After intense debate and pressure form industry and enviromentalists, congress amended the 1972 Act with the Clean water Act of 1977 (P.L. 95-217). The 1977 Act kept the controversial goal of zero discharge by 1985 but applied the goal to primarily toxic pollutants. The Act divides water pollutants into three categories: (1) toxic as determined by EPA, (2) nonconventional pollutants whose effects have not yet been determined, and (3) conventional such as dirt, organic wastes, and sewage. The deadline of installation of best conventional technology (BCT) for control of conventional pollutants was set at 1984 and EPA was granted to right to issue waivers in cases where the costs outweigh benefits. For nonoonventional pollutants the deadline for BCT was extended to mid-1987 with waivers possible. For toxic pollutants the deadline was 1984 with no waivers possible.

The Clean Water Act also allowed EPA to postpone the deadline for a municipality to have secondary treatment plants to 1983 if there were construction or funding problems involved, authorized $\$ 24.5$ billion for the construction of sewage treatment plants between 1978 and 1983, exempted congressionally approved projects such as dams, bridges, and dredging from the provisions of the National Enviromental Policy Act 
passed in 1969, and extended industry liability for oil spills cleanup from 12 miles to 200 miles offshore.

Section 208 of the 1972 Act was amended to include a Rural Clean Water Program (RCWP). The amendments authorized the the Secreatary of Agriculture, along with the Administrator of EPA, to establish and administer a program based on 5 to 10 year contracts with rural land owner's and operator's. These contracts promote the installation and maintenance of best management practices (BMP) to control water pollution and water quality degradtion from nonpoint sources. 'The RCWP provides financial and technical assistance through cost sharing for those practices that improve water quality and are consistent with the areawide waste treatment management plan.

The Soil and water Resources Conservation Act of 1977 (P.L 95-192) authorized the secretary of Agriculture to utilize the soil Conservation Service (SCS) in conducting an appraisal of the soil, water, and related resources of the Nation. The Act also directs the SCS to develop a soil and water conservation program based on this appraisal. The purpose of this Act is to ensure that the Department of Agriculture and the SCS programs for conserving soil, water, and related resources are responsive to the long-term needs of the Nation. The appraisals produced were to be used in soil and water conservation programs and policies and in planning, enacting, and implementing more effective protective programs.

The latest water legislation passed by Congress since the Clean Water Act is the Water Resources Development Act of 1986. This Act authorizes three humdred and seventy-seven projects and planning 
studies nationwide with an estimated cost of about $\$ 16$ billion dollars and has redefined the amounts of federal and non-federal shares of such projects. Three projects under this Act have been authorized in Rhode Island. These and the estimated total costs of each are;

Big River Reservior; Construction and study of the need for additional land to mitigate the loss of the fish and wildlife habitat at an estimated cost of $\$ 86.7$ million

Gortan's Pand Warwick; The removal of silt, massive aquatic growth, and other material at an estimated cost of $\$ 500,000$ dollars.

India Point Railroad Bridge; The demolition of the center span at an esitimated cost of $\$ 500,000$ dollars

(Source: RI Statewide Planning) 
Chapter Five

Rhode Island Laws and Agencies

This chapter will review the Rhode Island General Laws relating to water quality, the Rhode Island State Agencies and the agency roles in regulating water quality, the Rhode Island riparian water laws, and the issues planners face when dealing with water quality control in Rr. Planning techniques are needed that can be used in commities anticipating future water quality issues and some of these will be presented in the concluding chapter.

The general quality of Rhode Island waters is very high. In 1984 the Rhode Island Department of Enviromental Management (DEM) issued a report to the Enviromental Protection Agency (EPA) entitled "The State of the State's Waters". This report stated that $81 \%$ of all RI waters assessed supported fishable-swimable uses. This section shall emphasize how the Rhode Island General Laws affect the control of water quality at the state level through different departments and agencies. The major departments and agencies that have some impact on water quality and interaction with municipal plamers are : the Department of Health (DOH), the DEM, the Water Resources Board (WRB), the Public Utilities Cormission (PUC), and the Statewide Planning Program (SPP).

The DOH is the dominate enforcing agent under the EPA's federal regulations. Rhode Island General Law 23-1-18, "Department of Health", gives the DOH "the authority to set standards for human health dealing with the quality of all drinking water supplies and for the quality of the waters of the state". Rhode Island General Law 46-13, "Public 
Drinking Water supplies", gives the DaH the authority to set drinking water standards and monitor drinking water systems to ensure compliance with the EPA' federal standards. The DOH defines what a public water supply is and what the water quality standards should be for those public supplies. Rhode Island General Law 46-14, "Contamination of Drinking Water", sets DaH's authority to order the after-the-fact abatement of the introduction of a source of pollution into the watershed of any public drinking water supply whenever the DaH determines that the supply is in danger. DaH approval is required for any site plan for public wells. The site plan must show all existing or proposed potential sources of pollution within $500^{\prime}$ of a public well and within 1000' of a gravel packed public well. Iand use must be controlled between $200^{\prime}$ to $400^{\prime}$ of the well to ensure water quality protection. This requirement is something that planners should look at more closely. It allows planners to control a limited amount of land use for the purpose of water quality protection. The DaH routinely tests public water supplies for inorganics (arsenic, barium, cadmium, chomium, fluoride, lead, mercury, nitrate, delenium, and silver), organics (including endrinn, lindane, methoxgchlor, toxaphene, 2,4-D, and 2,4-D silvex), turbidity, coloform bacteria, and radioactivity. The DaH has set, acoording to the EPA's standards, safe drinking water levels for all of these constituents of water quality.

Rhode Island General Law 46-13 also gives the DoH the power over public water system suppliers to require that they correct pollution sources. Rhode Island General law 46-14 also allows the DOH to remove 
polluting material from public water sources itself. The major problem with relying an the DOH to protect water quality is the DaH monitors only existing public water supplies. No effort is made to protect or monitor potential public supplies that might come into use in the near future. Another problem is that no control is exerted over private supplies of water. A land owner or land developer may put a well anywhere so lang as it is behind the DEM's setback standards for septic systens. There are no construction codes or water quality criteria for private wells. The DaH will test private water supplies for suspected polluting materials, but has a strict confidential recording system which prevents the use of the test results from being used by analysts in both the public and private sectors. This presents a problem for planners in obtaining data to use. Another problem with the $\mathrm{DOH}$ is control over public water supplies is exerted only after the sipplies have already been polluted. The state laws that set up the departmental framework of the DaH do not contain preventive land use regulations or preventive pollutant discharge standards for water quality that planners could enforce.

The DEM is also authorized by the Rhode Island General Laws to manitor water quality. The water quality management program of DEM is authorized by Rhode Island General Law 46-12, "Water Pollution". This section originally provided for just the protection of surface waters but recently in 1983 the protection has been extended to groundwater. This chapter defines pollution as "the man-made or man-induoed alteration of the chemical, physical, biological, and radiological 
integrity of water". The DEM is the RI state agency that has set the water quality classification system and standards for RI. These standands define water quality classifications by the uses permited of the water. The fresh waters of RI are classified by use from Class A (highest quality, drinking water only) down to Class E (lowest quality, considered a nusiance condition). Salt waters are classified as well; Class SA being the highest to Class SC the lowest. Criteria exist for each class of water ie., Class A waters have different criteria than Class $B$ and the other classes. The criteria have taken into consideration general aquatic life, asthetics, dissolved oxygen, suspended solids, color, tunbitity, coliform bacteria, taste, ordor, ph level, thermal charges, chemical constituents, and phosphorous levels.

DEM also is in charge of the Rhode Island Pollutant Discharge Elimination Sysytem (RIPDES). This system controls the "issuing, modifying, revoking, reissuing, terminating, manitoring, and enforcing discharge permits and imposing and enforcing pretreatment requirements" (DEM RIPDES regulations). It is here that pollutant discharges into waterways are regulated so as to maintain water quality. The RIPDES applies to all point source discharges. A point source discharge is a discharge of pollutants that can be regularly located as to the source of the discharge. DEM does not have a way of controlling non-point source discharges. This is most commanly done at the muicipal level by erosion and sediment control ordinances. Few muicipalities have gone so far as to address the issue of water quality protection as a seperate item requiring its own ordinance. 
Another way DEM works with water quality is the monitoring of pesticides present in water supplies and water bodies. Rhode Island General Iaw 23-25, "Pesticide Control", makes it illegal in the state of RI to dispose of or store pesticides or pesticide containers in any way that would pollute water bodies. DEM also regulates the possible potential pollution of waters by hazarduous wastes through Rhode Island General Iaw 23-19.1, "Hazardous Waste Management". This Chapter protects surface water and grouncwater fram pollution through a regulated permit system.

Rhode Island General Law 23-18.9, "Refuse Disposal" gives DEM the authority to regulate solid waste disposal procedures that have been proven to degrade the quality of surface or groundwater resources. Solid waste disposal is illegal in areas that have been designated as a public drinking water source by a muicipality and where the municipality has enacted an ordinance relating to such water sources. Several towns, North Kingstown and Richmond notably, have enacted such aquifer protection ordinances.

In terms of water quality, DEM's most important contribution is the development of the water quality classification system for the state. It is important that classification be set at the state departmental level and be adhered to by municipalities to provide for uniform conformity within the state. Surface water resources often overlap commitity boundries and individual classification systems might create conflicts. A planner can obtain the water quality designations for all surface water areas in his/her commmity very easily from the 
DEM. DEM's other programs, like the DoH's, deal with current land uses and point source pollution. Municipalities must realize that nonpoint sources can cumulatively have a more damaging effect than a single regulated point source. Methods must be adopted to check that nompoint sources will not be more detrimental to water quality than point source pollution.

The RI Water Resources Board (WRB) was created by Rhode Island General Law 46-1, "water Resources Board". This chapter also outlined a general water resources policy for the state of RI. RI's policy is geared to focussing on the problems of drinking water supply as the proirity use of the State's water resources. The WRB has the authority to formulate lang range plans for the development of major water sources for the State. It also has the authority to authorize water supply agencies and allow these agencies to supply water under contract. The WRB has studied and issued many reports dealing with both surface and groundwater resources but water quality is not one of its primary focuses. Supply is its biggest concern. The WRB has attempted to proceed with the development of the Big River Reservor Project and to acoquire sites in southern RI for public supply wells.

Perhaps missing fram the WRB policy is one of the fundamental elements of planning. That element is a comprehensive plan. They have not yet published a long range comprehensive public water supply plan which includes the entire state and considers water quality within it as well. The WRB does not have any substantive standards for the operations of water supply agencies that it empowers and regulates. A 
planner looking for municipal water supplies for a conmmity with limited resources would find a state comprehensive plan for water supply helpful.

Rhode Island General Law 39-1, "Public Utilities Cormision" gives the Public Utilities Commision (PUC) the authority over water supply systems in the area of rate making, operations and plans that affect rates, and the imposition of mandating restrictions during times of drought in water utility areas. A water supply system is respansible to the PUC if it obtains water from a sarrce owned or leased by the WRB, obtains loans from the WRB, or any system which sells water outside of its district or franchise limits. The PUC's main function in the area of water is rate regulation. It does not have policies conceming water quality but it is mentioned here because it occasionally has to regulate the amount of water used in low supply areas. Oftentimes the availibity of water or scarcity of water has impacts on the waters's quality.

The state agency which has done the most work on water quality is the RI Statewide Planning Program (SPP). This agency differs from the above agencies in that it has no regulatory authority. It cannot cantrol land use patterns that affect water quality. Section 42-11-10 of the Rhode Island General Laws call for a "comprehensive strategic planning process and the preparation, maintenance or plans for the physical, econamic, and social development of the state". The SPP provides policy guidance and coordinates these activities. The Division of Planning is comprised of the Office of Strategic Planning, 
the office of Systems Planning, and the Office of Municipal Affairs.

The SPP was the agency that prepared the RI 208 Water quality Management Plan. This plan came about due to mandates of Section 208 of the Clean Water Act. The Act recognized that pollution problems do not follow linear boundaries and the need for areawide planning. Section 208, entitled Areawide Waste Treatment Management, was directed act "enoouring and facilitating the develogment and implementation of areawide waste treatment management plans." The Section 208 Program of the Act was intended to be the means of undertaking the analytical tasks of the Act and making the decisions about desired water quality and the means to achieve it.

The plan was drafted and reworked many times and proposed many recammendations concerning water quality. One of these recammendations was for municipalities to adopt a model ordinance, contained in the plan, for the express purpose of protecting the health and safety of the commuity by maintaining the qualities of its water through protection measures. SPP has backed mary bills dealing with water quality protection and state land use management. A planner must work most closely with the SPP. Certainly this program will have the most impact in the area of water quality in the future.

In 1972, Congress passed amendments to the Federal pollution Control Act that changed the course of pollution related legislation (Kamieniecki,1980). 
The abjective of the amendments were to "restore and maintain the chemical, physical, and biological integrity of the nations's waters". The Act recognized that pollution problems do not follow linear boundries and therefore the need for areawide planning. Section 208, entitled Areawide Waste Treament Management, is directed at "enoouraging and faciliating the development and implementation of areawide waste treatment management plans".

Section 208's program was intended to be the means of undertaking the analytical tasks of the Act and to make the decisions about desired water qualities and the methods to obtain them. Section 208 enbodied several significant changes in approach to the water quality problems of the pre-existing statutes before the 1972 amendments. Section 208 was considered an implementation program to determine ways to meet the Act's 1983 goal of "water quality which provides for the protection and propagation of fish, shellfish, and wildlife and provide for recreation in and on the water". The section called for the requirements to be fulfilled either by a state or by a locally operating planning agency in a designated regional area. The designated planning agency must procuce not only a plan but also designate management agencies that will implement this plan. The Act intended for 208 planning to be a continuous process that sought the most effective ways of controlling water quality. All activities that result in water pollution and an 
anlysis of alternative methods for reducing water pollution were to be included in the plans. Unlike previous federal water quality programs, Section 208 provided for the management of non-point sources of pollution as well as point sources of pollution.

The requirements of the section intended to bring together a number of various aspects of water pollution problens. The section intended that planning should ultimately develop mechanisms for dealing with nompoint sources of pollutants. In addition to tying these different aspects of water pollution together under one planning system, 208 planning alos provides opportunities to coordinate water quality planning with other environmental activities. Areawide planning should look at the issue of development in terms of its environmental implications according to the section. This part of the scetion has been viewed as a round about way of intergrating some land use policies into this dederal legislation. Water quality is related to land use decisions. The solutions to water quality problems vary in effectiveness depending on land use patterns.

According to the EPA regulations published in Guidelines for State and Areawide Water Quality Management Program Development, 1976, and the statutory language of section 208 information included in an areawide waste treatment management plan should identify the following:

* All treatment works needed to maintain acceptable water quality 
over a 20 year period. The list should be revised annually to reflect changing conditions. The plan should establish priorities for building or modifying treatment plants and create time schedules to put these priorities into effect.

* All mechanisms to coordinate all watse treatment plamning activities within the planning area. These mechanisms should regulate the location, modification, or construction of all facilities within the area.

* The management agency to be respansible for implementing the plan. The agency must have the legal authority to carry out the plan, either directly or through contractual agreements. The management system identified in the plan be be approved by EPA before the plan can be put into effect.

* Means of dealing with nan-point source pollutants.

* Other information needed to carry out the plan. This should include data on financing arrangements, time requirements, the anticipated cost of implementing the plan, and its probable economic, social, and environmental effects on the planning area.

* Methods to dispose of the residues and treated wastewater that remains after treatment. This requires defining the problems associated with land and subsurface disposal of these wastes.

* The techical planning process should cansist of the identification or priority water quality problems in the area, the reoognition of any constraints in dealing with the probelms, and 
development of altematives to achieve water quality goals. Technical planning should also include mmicipal wasteter treatment systems, industrial wastewater pretreatment or treatment, residual waste management, urban stormwater management, and non-point source management.

* An evaluation of the management requirements of the 208 program and the ability of the existing agencies to carry out the management requirements.

* Institutional problems (Lack of authority, or lack of financial capacity) should be identified in the plan. Alternative means to accquire proper authority, financial capacity, and effective institutional arrangements should be evaluated.

This section of will deal with how the State of Rhode Island fufilled the requirements of section 208. In April, 1975 the former governor, Philip Noel, designated 38 Rhode Island communities and the two neighboring communities of Blackstone and Milliville, Massachusetts as a single "208" planning area. This fufills the requirement of designating the planning area boundries. He then designated the Rhode Island Statewide Planning Program (SPP) as the lead agency responsible for developing the Rhode Island "208" plan. This fufuilled the requiement of a lead agency but the SPP has no regulatory authority of its own. Following this designation EPA awarded Rhode Island $\$ 2.3$ million dollars to cary out the study. SPP spent 1975 preparing a work program and started the actual study in 1976. 
In Novenber, 1978, a preliminary draft report was issued. The final plan was produced in March, 1979 after public meetings here held for public input, and expert opinions were solicited. On March 3, 1980, the Governor, certified the plan as the water quality management plan for Rhode Island. EPA reviewed the plan and approved it with the condition that implementation strategies had to be developed. The certification by both the Governor and EPA formally established the plan as the document to used in the development of statewide water pollution control legislation. The signifiance of EPA's approval of the plan is that all future water quality management action programs and funding are to be consistent with the conditions set forth in the plan.

The following is a list of the elements that are contained in the final plan issued in 1979 ( 208 Water Quality Management Plan for Rhode Island, 1979):

Defined planning boundaries

Water quality assessment and segement classifications

Population inventories

Population projections

Non Point Source Assessment of:

Agriculture

Silviculture

construction

Unban nunoff 
Landfills

Hydrologic modifications

Land Use

Marinas

Water quality standards

Point source allocations

Municipal Waste Treatment Needs Dealing With:

Water conservation

an-lot sewage disposal

Municipal needs

Construction grants

qperation and maintenance of plants

Pretreatment of industrial wastes

Chlorination

Providence River

Pawturuxet River

Industrial waste treatment sysytem needs

Resicual waste control neods

Target implementation dates

Management agencies

It appears the Rhode Island did fulfill the statutue requirements of section 208 based on my interpetation. The fact the EPA certified the plan backs up my opinion as well. The major item not cantained in the plan was a septage dispoal program. The plan defined many relevant 
issues for regulatory programs to be enacted but did not have the necessary legislation in place yet to develop implementation stragtegies for them. This drive for implementation legislation is the major focus of SPP now the plan has been completed.

To implement the recormendations of the 208 plan, EPA granted Rhode Island another $\$ 208,000$ to develop the needed legislation to carry out the plan, to develop prograns to protect groundwater maintain septic systems, septage management, to protect the south shore Rhode Island coastal pands, and to mitigate pollution in upper Narragansett Bay. Most of the reconmendations of the plan callled for new legislation to be passed in Rhode Island. In the area of state legislation is where the 208 planning process has had a significant impact in Rhode Island. SPP proposed and is still working on proposals for legislation to implement the various recormendations of the 208 plan. The following section sumerizes the legislative actions introduoed by the SPP and were passed into law. SPP has introduced many more items than the few mentioned here and is still working on having them adopted into the Rhode Island General Laws.

1982- $\mathrm{H}$ 7446- An Act relating to Soil Erosion. Cities and Towns are authorized to enact ordinances controlling soil erosion and sedimentation. A model ordinanoe is contained in the Act. The Act was approved by the general assembly and signed by the governor in May, 1982. 
- S 2314- An Act relating to hazardous waste facilities. It establishes procedures for evaluating and permiting of hazardous waste management in areas zoned for manufactoring. Facilities are permited in such area and if licensed by RI DEM the conmunity must permit the facility, but can negociate a siting aggreement. The bill was approved by both houses of the General Assembly and was signed by the Govneror.

- S 2335- An Act relating to disposal of solid waste over drinking water resources. Groumdwater reserviors and recharge areas identified in the 208 plan may be designated as existing, planned, or potential public drinking water sources. Public hearings must be held by both the community concermed and RI DEM. Solid watse may not be disposed of in areas designated through this procecture. The bill was passed by the General Assembly and signed by the Governor.

To summerize the content of the plan, it contained a total of two hundred and twenty-four recommendations for the management of water quality in Rhode Island. According to SPP's 208 Water Quality Management Plan for Rhode Island: Status of Recommendations, 1982, 81 of the recommendations had been implemented by 1983, between 1983 and 198482 recommendations were in the process of being implemented. 
Between 1984 and today, SPP is working on the reminaing 61 recommendations. It is foreseeable that some of the recormendations may never be implemented. The office of SPP has worked in developing, drafting, and lobbying for the legislation that was called for in the plan. The problem that SPP faces is inherent with all legislation; no one can predict what the General Assembly will do to environmental bills.

The 208 plan that was prepared for Rhode Island is important for several reasons to the enviromental issues of today. It developed detailed research procoesses for previously ignored water pollution issues. It developed and linked together data collection on related issues. The planning process involved the synthesis and cooperation of many levels of govermment and governmental agencies in Rhode Island. It was a process which incorporated many different factes of pollution problems. Although not an answer to pollution, the requirements of Secttion of 208 of the Clean Water Act are aimed many of the pollution sorrces. It is doubtful we will ever eliminate pollution but knowledge about pollution processes and identification of sources can help reduce pollution.

The Rhode Island 208 plan prepared and maintains a data base to make decisions about water pollution problems in the state of Rhode Island. Although many of the recomendations of the plan have not been adopted, Rhode Island legislation has been affected. Because of the plan, enviromental legislation is becoming more comman in the Rhode 
Island General Assenbly. 208 planning is a continuous process. While not in the forefront of the media today, it has influenoed and laid the groundwork for many of the environmental issues in the media today. perhaps this is the biggest thing 208 planning has accoomplished in Rhode Island to this day.

Rhode Island Municipal Laws

Mnicipal cormunties receive their powers from the state. The Rhode Island General Laws that deal with the assigment of powers to municipalities are referred to as the "Enabling Legislation". They received this name because they describe what municipalities are "able" to regulate. Rhode Island General Law 45-24, "Zoning Ordinanoes", enpowers municipalities to adopt zoning districts and regulations necessary to protect public health and safety, provide water, sewers, and infrastructure. Rhode Island General Law 45-23, "Subdivision of Land", enpowers municipal councils to authorize their planning cammisions/boards to adopt rules and regulations to govern how the subdivision of land is to oocur. The purpose of subdivision regulations are to provide for equally distributed transportation services, water supplies, sewerage services, recreation, and other public utilities. Rhode Island General Law 45-46, "Soil Erosion and sediment Control", authorizes municipalities to adopt ordinances that require development procedures which limit causes of erosion and sediment loads. Most RI municipalities have adopted this type of ordinance but not the model ordinance for protecting water quality suggested by the RI 208 Plan. 
The town of Middletown has recently adopted a Watershed Protection District. This district is a zoning overlay to superceed the requirements of the regular zones for the purpose of protecting the surface and underground drinking water supplies of the comminity. At the municipal level planners would be the instrumentalists in getting such an ordinance passed. However, in writing such an ordinance planners must be aware of the common laws that govern water use and water rights in the state of RI. They must keep in mind the rights considered to be inherent in the ownership of property.

In RI the type of water doctrine which governs the comman case law is the riparian doctrine. In riparian doctrine, the rights to water arise from and only from the ownership of land which adjions the land which is riparian. Riparian land is that land next to water. The rights and duties associated with the riaprian system of water law are:

1. Rights to the use of water in a stream are created by ownership of land wich is riparian to that stream. Water rights are a facet of land ownership and these rights cannot be lost by disuse.

2. A riparian owner may use water only on the riparian tract of land and may not sell it to another for use off the land.

3. Between themselves riparian owners on a given stream are subject to two principal theories, natural flow and reasonable use. Natural flow is an absolutest concept that says except for minor damestic uses no riparian may impair or reduce the flow of a stream to the detriment of another riparian. 
All parties are entitled to have the stream flow past their land as it would in nature (Layperson's Guide to Water Rights Law, 1985). The reasonable use corollary of riparian rights says that each riparian owner can make a reasonable use of the water provided he/she takes into account the needs and uses of the other riparian owners.

In RI riparian rights can be acquires through ownership of the land or through purchase of the land independent of the land and can be seperated from the land by deed or other instrument of conveyance. [Cram v. Chase 25 R.I. 98, 85 Alt 642 (1913)]. But if the deed conveying riparian land is silent as to water use then the right to use the water passes with riparian land. [Lonsdale v. City of Woonsocket 25 R.I. 428, 56 Atl 448 (1903]. Eurthermore it is also possible to have an involuntary transfer by preccription and adverse use. [Dyer v. Cranston Print Works 22 R.I. 506, 48 Atl 791 (1901)]. In considering RI water case law the reasonable use rule prevails. [Silver Spring B\&D Co. V. city of Woonsocket 13 R.I. 611 (1882) Lonsdale V. City of Woonsocket 25 R.I. 428, 56 Atl 448 (1903)]. Reasonable uses for riparian puposes must consider the size and nature of the stream and the needs of the area. Domestic uses and industrial uses are considered reasonable uses with preference given to damestic and agricultural purposes to the exclusion of others. [Lonsdale v. City of Woansocket 25 R.I. 428, 56 Atl 448 (1903)].

The problem with the reasonable use doctrine is that there are no contraints to the theory. An owner may use all the water he/she wishes 
as long as the use to which he/she puts the water is on the land from whence it is taken. The question which planners would be conoemed with is are future uses for depleted water supplies compensable and what types of existing uses will be compensated by the courts ? Will regulating water quality be construed as a taking issue ? could riparian owners sue for damages? Future uses of a resource for which damages are sought is a very specultive issue and I doubt that few courts would be willing to tackle it in the near future. It is one of the issues that approaches the realm of dictating future land use. The law will compensate for damages to an existing use of water. The case of In Application and Petition of Huie 202 N.Y.S. 2d 954, 11 A.D. $2 d$ 837 (1960) raised the issues of existing use. The claimants were the licensees of riparian owners of water and suffered business losses when the city decided to utilize the river for water supply purposes. Under the New York Stature damages were allowed.

The problems of relying on the courts for managingg water quality are complex. One of the biggest problems with using the courts to maintain water quality and any type of planning issue is that the courts do not have the expertise or comprehensive resource plarning backgrounds to maximize the efficient allocation of resources. Often trade-offs cocurr as a result of conflicting goals. Courts decide what is not a legitimate land use and avoid defining what is a legitimate land use. For planners dealing with water quality, the problem with corman law stare decisous is that unless a particular problem has been 
decided in court before, the planner would be uncertain of what the municipal rights and responsiblities should be. The courts resolve most issues after they have already oocurd. Solutions to the problem may not be brought into effect until the case is finally decided. Water quality once degraded will stay that way until something is done about it. The pollution source must be removed as soon as possible, therefore, planners must often use court ordered injunctions to stop a particular use fram polluting a water supply.

This fact leads to the creation of instituations to allocate and distribute land and other resoucres equitably. The problem with water quality planning at the municipal level is a facet of the problem that is inherent to all land use planning. There is no social consenus about how land shpuld be used.

The degradation and pollution of water resources by private parties results from the absense of property rights or incompletness of property rights for water resources. Water resources may be seen as a public good. The definition of a public good is that the use by one member of society does not recuce or elimination the use of the same resource by another menber of society. Public goods have social benefits associated with themand the maintaince of water quality can be seen as a social benfit for all menbers of a coummity. The social welfare of a community may be lessened by individuals that degrade water quality and do not have to take into account the adverse affects of their use of water resources. 
The decisions that established the constitutionality, and theoretical base for the regulation of land use, were passed down by the US Supreme Court in the Pennsylvania v. Mahon and Euclid v. Ambler cases in the 1920 's. The powers of state and local governments to regulate land use were affirmed and proved to be an appropiate exercise of the police power to protect public health and safety. Zoning is the land-use control device that extends, defines, and limits land use. Zoning also can be seen as one method of for the resolution of conflicting land uses. The regulation of air, noise, and water pollution under the police power of a muicipality to protect its citizens from detriment and danger has been upheld in these two cases. Zoning deals with problems growing out of the use of private property. Municipal RI communties have not yet addressed the maintaince of water quality in their zoning or subdivision regulations. one method. of institutional protection for water resouces would be for municipalities to adopt an ammendment to their ordinances that would layout regulations and development procectures to prevent the degradation of water resources.

However, institutional regulations that control the use of land like zoning cannot make individuals, and corporations take into acoount the real costs of their degradation of water quality. Thus there must be some additional legislation by the state and muicipalities to declare public ownership of water resources. This legislation should allow for better local control of water quality. This control can be 
enacted when actions by individuals adversely affect the quality of the community's water resources. The public ownership of water resources would allow a fee to be collected for any use of water resources that diminishes the quality of the water left for others. Its social function is to assure that the opportunity cost of using a resource will be taken into account by the user. The fee will also provide additional income to the municipality as well as to the state. The recognition of public property of water should be asserted to ensure the efficient and equitable mangement of the resources. The user of a resource who imposes costs on others would required to internalize such costs.

The Rhode Island General Laws that establish the agencies of the DOH, the DEM, the WRB, and the SPP form the regulations and institutional organizations that municipal planners must work with in the protection of water quality. The time to deal with water quality planning is before the degradtion oocurs and nusiance conditions result. Planning is necessary to avoid what could prove to be very costly for muicpalities in the future. An innovative planning tool would be the fee user system for pollutors. The federal Enviranmental Protection Agency has suggested imposing fines on polluters for years. A fee system at the local level would allow muicipalities more control over water resources. Other planning methods such as ectucation of the public about the problem, and comprehensive water planning should be considered as well. Water quality planning can be acoompished at the 
local level under current enabling legislation. I feel this itself will not be adequate to preserve water quality. With the pace at which suburbanization is spreading to rural areas, and the demand for services following just as rapidly, planners will be facing the problem of water supply and quality. The concluding chapter of this study will present a model comprhensive plan containing principles that Rhode Island comminities could adopt for use in protecting water quality. 
Chapter Six

Reconmendations and Conclusion

In addition to the legal insitutions of water rights, and problems of preventing water pollution, another area of water quality protection deals with the public authorities who regulate the management and use of water resources. The long range abjective in the control of rivers and streams is to maximize the benefits from the development of the land and water resources for all purposes necessary to meet future needs. This final chapter will present the most commanly used practices of water quality protection devices. With population growth and urban expansion a present issue for planners in Rhode Island, today is the time to ensure protection of the water resources of the future. This chapter contains a model comprehensive water quality protection plan that could be adapted to fit any Rhode Island community. The plan is a reflection and synthesis of the information and data in all the preceeding chapters. It is recammended that Rhode Island communities adopt the principals contained in this plan for the protection of surface water quality supplies. 


\section{Water Quality Comprehensive Protection Plan}

Introduction

Envirommental quality is intimately related to patterns of land use and growth. Without land use and growth management provisions, a community relying solely on discharge permit programs might eliminate discharge fram point sources anly to find that the rivers and streans remain polluted from non-point sources. Land use and growth management policies must consider both types of pollution. The public expense in developing water protection programs would rarely approach the amount of money a commity would have to spend on constructing and operating treatment facilities. This plan is divided into four sections that focus on the efforts local comminities can do to reduce water quality degradation. The plan is divided into reccommendations on urban rumoff and municipal regulatory devices, land use planning, road salt, erosion and sediment control, vegetative protection measures, non-structural protection measures, structural protection measures, and water management planning. Each section focuses on the applicability, and planning considerations of the presented methods. There are many differing methods of controlling pollution in use today, this plan limits itself to those that would be most cammolly availible to Rhode Island communities. 


\section{Urban Rumoff}

Unban growth and related development can have major impacts on water resources and water quality. Urban growth results in an increased demand for water and increases wastewater flows and pollutant loads. Increased flows and loads will degrade the current water quality below desirable levels. It will also increase the amount of nmoff generated. As the proportion of impervious land is increased, increased quanities of water will not be absorbed. Such stonmater may add a significant pollutant load to the receiving streams. Dust and chemicals deposited on the land surface will be transported by stonmater nunoff.

The alternatives availible to control urban runoff fall into two broad categories. They are structural measures and non-structural. Structural measures are correctional in nature; they treat the numoff after the storm event has oocurred. These measures will be focussed on in their own section. Nan-structural measures are preventive in intent; they are geared to recucing the rumoff before the storm event occurrs. Non-structural measures can be divided into to subcategories; regulatory approaches and operational approaches. Operational approaches remove polluting materials before they are washed into the receiving waters and will be discussed in their own section.

Regulatory approaches attempt to control urabn numoff pollution by controlling its intensity and limiting the amount of runoff produced by varying types of land uses. They present opportunities to affect the pattern of urbanization as it occurs. They are useful because when enforced correctly they help prevent many of the problems that are 
inherent in the built environment. This section presents several model ordinanoes that deal with various aspects of water quality protection. The first ordinance is a model ordinance written for the purpose of protecting local water quality. The second ordinance is an ordinance for the protection of drinking water watersheds. The last ordinance of this section is an ordinance for the protection of groundwater aquifer water supplies.

\section{Land Use Planning}

As mentioned before, land use planning will influence the quality of our enviroment. Land use planning, particularly as it affects water quality, should have the following goals: (Pavoni, 1977)

1. To guide the safe and productive use of land and water resources by private and public land owners.

2. To protect surface and subsurface water resources from land use generated pollutants which threaten aquatic ecosystems.

3. To develop land use policies and procechres which

A) maximize infiltration of rainfall where it is received

B) minimize alteration of natural surfaces and sub-surface drainage flows

4. Minimize land uses which have unknown but potentially hazardous water quality impacts.

Planners when establishing land use planning objectives need to understand economic goals and limitations of the comminity, recent trends and projections of population growth, the physical characteristics of the community's land resources, the nature of the 
Town of $\mathrm{X}$

TITIE OF THE TOWN OF ENTITIED ".........." IS HEARBY AMENDED AS FOLIONS:

Chapter 1.1

Ordinance for the control and the protection of Water Quality

Sections:

\author{
1.1.010 Preamble \\ 1.1.020 Purpose \\ 1.1.030 Adninistration \\ 1.1.040 Definitions \\ 1.1.050 Water Quality Designations \\ 1.1.060 Site Plan Review \\ 1.1.070 Compliance \\ 1.1.080 Effective Date
}

1.1.010 Preamble. Acting under the authority granted under sections 45-24 and 45-23 of the General Iaws of Rhode Island, as ammended 1956, the Town Council of the Town of $X$ hereby establishes this section for the protection of water quality in surface water bodies, streams, wetlands, and rivers in the Town of X. The provisions of the section shall apply to all surface water bodies, streams, wetlands, and rivers within the Town of $\mathrm{X}$. The benefits of water quality protection are the enhancement of asthetics of the commuity, amenity values to develogment, increased recreational apportunities, protection of aquatic habitats, and protection of water supply areas.

1.1.020 Purpose. The standards set forth in this section are made for the express purpose of promoting the public interest, general health, safety, and economic and general welfare of the Town by regulating development procedures, uses and modifications of water related areas that have been proven to cause degradation of the quality of surface water bodies, streams, wetlands, and rivers.

1.1.030 Administration. This water quality protection ordinance shall be administered by the Town Council. The Town Council shall designate the Plaming Board as the board responsible for the carrying out of this ordinance. The Plaming Board as appointed by the Town Council shall also be responsible for the maintaining of the official map for this water quality ordinance. This map shall show:

A. A town map for offical use showing all surface water bodies, streams, wetlands, and rivers and the designated class of water quality for each water body, stream, wetland, or river. 
1.1.040 Definitions. The following definitions shall be applicable to this section:

Carrying Capacity- Maximum population that a given ecosystem can support under a given set of conditions

Control Structure- Structure designed to control the volume of runoff of storm water that passes through it during a specific length of time

Dry Bottom Storm Water Storage Area- A faciltiy that is designed to be normally dry and contains water only when exoess storm water runoff occurs

Excess Storm Water- Portion of storm water runoff which execeeds the transportation capacity of natural drainage channels

Natural Drainage- Channels formed by the existing surface topograpginy of the earth prior to changes made by umatutral causes

Person- The word "Person" shall include the singular and the plural, and shall include an individual, individuals, a firm, corporation, partnership, foundation, association, company, institution, organization, or any other recognized legal entity

Rip-Rapping- Covering slopes of drainage areas with rock or other material to prevent erosin

Runoff- Water that results from precipitation which is not absorbed by soil or plant material

Safe Storm Drainage Capacity- The quanity of storm water rumoff that can be transported by a channel or control device without having the water surface rise above the level of the earth's surface next to the waterway.

Storm Water Storage Area- Areas designated to store excess storm water.

Storm water Rumoff Release Rate- Rate at which runoff is released fram dominant to serviant land.

Waters- Means all surface water, including all tidal waters, wetlands, land masses partially or wholly submerged in water, which have been or will be used in conmerce, industry, recreation, or residential purposes

Wet Bottom Storm Water Storage Area- A facility that is designed to be maintained as a numoff discharge area that will contain water constantly 
1.1.050 Water Quality Designations. All waters of the State of Rhode Island have been categorized by the Department of Enviromental Management (DEM) based on considerations of public health, recreation, propogation and protection of fish, shellfish, and wildlife, and economic and social development. The Town coumcil deems it appropiate to further use the DEM's water quality standards for the Town of X. This will provide for conformance with the Rhode Island General laws and allow conformity with other surrounding commities. A water quality standard defines the quality goals of a water body, or portion thereof, by designating the use of uses to be made of the water and by setting criteria necessary to protect the uses. The waters of the Town of $X$ shall be assigned to one of the DEM's classifications which are listed below. Each class is defined by the most sensitive, and therefore governing, uses which it is intended to protect:

Fresh Water:

Class A-(Drinking) water supply

Class B -Public Water Supply with appropiate treatment -Agricultural uses - Contact Recreational Activities -Fish and Wildlife Habitat

Class C -Boating and secondary recreational activities -Fish and wildlife Habitat -Industrial processes and cooling

Class D -Migration of Fish -Good asthetic value

Class E -Nuisance Condiditions; uses limited to: -certain industrial processes and cooling -Power

Sea Water -Navigation

Class SA -Bathing and contact recreation -Shellfish harvesting for direct human consumption -Fish and Wildlife habitat

Class SB -Shellfish harvesting for human consumption after dupuration

-Bathing and contact recreation

-Fish and Wildlife Habitat

Class SC -Boating and secondary recreation

-Fish and wildlife Habitat

-Industrial cooling

-Good asthetic value

All small streams tributary to Class A waters shall be Class A. All other small streams where classification is not indicated shall be Class B. All other fresh waters not classified shall be considered to be Class A until classified. All seawaters not classified shall be considered to be Class SA until classified acoording to the DEM. 


\section{$\underline{1.1 .060 \text { Site Plan Review }}$}

A. Data Required

Six (6) sets of plans for the control of erosion, storm water rumoff, and the protection of surface water quality for each nonoontiguous site shall be submitted to the Planning Board by an engineer or land surveyor registered under the provisions of Title 5, Chapter 8 of the Ceneral Laws of Rhode Island, 1956. There shall be a seperate plan for each proposed final section shown on the preliminary plat. The plan shall contain the following:

1. A site plan showing the grades, elevations and contours of the land prior to disturbance and the proposed grades, elevations and contours to be created. Tho foot (2') contour intervals shall be required. Where slopes are 38 or less one foot $\left(1^{\prime}\right)$ contour intervals shall be required. On slopes of less than 18 spot or grid elevations shall be used.

2. Location and description of existing natural and mamade features including the existing surface drainage characteristics, location, size, and water quality of any water bodies or wetlands on the property where the work is to be performed, on land of adjacent owners which are within 100 feet of the property, or which may be adverseley affected by the proposed alterations.

3. Measures for soil erosion and sediment control must meet or exceed standards and regulations set forth in the specifications of the Rhode Island Erosion and Sediment Control Handbook, prepared by the USDA Soil Conservation Service in cooperation with the Southern RI Conservation District. Such Erosion and Sediment Control Handbook shall be on file at the office of the Town Clerk. Rainfall intensities used in hydrologic computations shall not be less than that shown by applicable rainfall curves published by the uS Department of Conmerce, Weather Bureau.

4. A schedule of the sequence of installation or application of plamed erosion and storm water control measures, both temporary and permanent, as related to the progress of the project, including the total area of soil surface which is to be disturbed during each stage, the impacts of such soil disturbance, and estimated starting and completion dates.

5. A description of methods to be employed in processing and disposing of soil and other material that is removed from the grading site, including the location of disposal sites.

6. A soil survey or soils engineering report including data regarding the nature, distribution, and strength of existing soils, grading procecures, and design criteria for corrective measures. The soil 
investigation and subsequent report shall be completed and presented to the Planning Board by a professional engineer registered in the State of Rhode Island.

7. A slope stablization plan and revegetation plan which shall include a complete description of the existing vegetation, the vegetation to be removed and the method of disposal, the vegetation to be planted, and slope stablizing measures to be installed, including the environmental effects of such operations on slope stability, soil erosion, and water quality.

8. An engineering hydraulic analysis of storm water nunoff under existing site conditions, under proposed developed site conditions, and a detailed evaluation of the project effects of surface runoff on property adjoining the site, on existing drainage facilities and systerns, on ground water quality, and on site and downstream surface water quality and carrying capacity. Such analysis shall include a plan showing the drainage area, the effect of proposed development on hydrologic oonditions and water quality.

9. The proposed water supply and sanitation system and the ability of these systems to prevent disease, contamination of ground water, unsanitary conditions, and degradtion of water quality.

10. Any other requirements or data that the Planning Board may require in order to adequately evaluate the proposed development. All revisions of data required shall be submitted to the planning board.

\section{B. Design Standards and Regulations}

1. Develqament shall be accomplished so as to minimize adverse effects upan the existing topography, soil conditions, and to minimize the potential for erosion and protect existing water quality classifications within the site.

2. Development shall be oriented to the site so that grading and site preparation is kept to a minimum. Plans calling for cutting and filling or stripping of vegetation may not be approved by the Planning Board if it is determined that the proposed land uses could be supported with less alteration of the natural terrain, vegetation, and maintainence of water quality within and adjacent to the site. Natural vegetation shall be maintained and protected.

3. Erosion and sediment control measures shall be coordinated with the sequence of grading, development, and construction operations. Control measures such as hydro-seeding, berms, interceptor ditches, mulching, matting, temporary vegetation, rip-rapping, terraces, and sediment traps shall be used prior to the commencement of each stage of the development process. 
4. Soils, construction and other materials shall not be stored in locations which would cause suffocation of root systems of trees to be preserved or in areas having impact on groundwater and surface water quality.

5. Proposals shall strive for retention of the natural features and qualities of the site, and development shall seek to enhanoe these natural features and qualities.

6. Lots shall be developed to maximize the amount of natural drainage which is percolated into the soil and to minimize overland runoff into adjoining streets and water courses to protect the water quality in those courses.

7. Grading shall not be done so as to divert water onto the property of another lanowner without the expressed consent of that landowner and the Planning Board.

8. Within ten (10') of adjoining property, limit changes to existing grade to slope of $2: 1$. Provide retaining structures to contain slopes that exceed the 2:1 ratio.

\section{Septic Setbacks}

No disposal trench, disposal bed, cesspool, seepage pit or other facility designed to leach liquid wastes into the soil shall be located:

1. Within $150\left(150^{\prime}\right)$ feet of a "Fresh water wetlands" as defined in Title 2, Chapter 1 of the General Laws of Rhode Island, 1956, as ammended, excluding from such definitions:

A. That area of land within fifty $\left(50^{\prime}\right)$ of the edge of any bog, marsh, swamp, or pand.

B. That area of land within two hundred $\left(200^{\prime}\right)$ feet of the edge of any flowing body of water having a width of more than ten $\left(10^{\prime}\right)$.

C. That area of land within one hundred $\left(100^{\prime}\right)$ feet of the edge of any flowing body of water having a width of less than ten (10') feet during normal flow.

D. That area defined as a "Food Plain" in said Title 2, Chapter 1.

2. Within one hundred fifty (150') feet of a "River" as defined in said Title 2, Chapter 1.

3. Within one hundred fifty (150') feet of the flood water source if such facility is located on a "Flood Plain" as defined in said Title 2, Chapter 1. 


\section{Septic Systems}

1. No effluent shall contain any acid, oils, dust, toxic materials, corrosive or suspension which would create odors, discolor, poison, or otherwise pollute or degrade the quality of any river, pond, stream, wetland, or any drinking water supply.

2. No discharge shall raise the temperature of any waterbody above the temperature which can support normal aquatic life in such waterbody.

E. Storm Water Rumoff.

1. The controlled release and storage of excess storm water nunoff shall be required for all development in the Town.

2. The release rate of storm water nunoff from the sub-watershed shall not exceed the existing storm drainage capacity of the natural drainage system. There will be a net zero runoff rate for the site.

3. The required volume for storm water detention shal be calculated on the basis of the nunoff from a 100 frequency rainfall of any duration as published by the US Department of Conmerce, Weather Bureau.

4. Dry bottom storage areas shall be designed to serve a secondary purpose for recreation, open space, or other types of uses that will not be adversely affected by flooding.

5. Outlet control structures shall be designed as simply as possible and shall require little or no attention for proper operation. Fach storm water storage area shall be provided with a method of emergency overflow in the event that a stom in excess of the 100 year frequency storm oocurs.

6. The use of restrictive fences around storm water control devices shall be kept to a minimum and used only as a last resort when no other method is feasible.

7. Sediment basins (debris basins, desilting basins, or silt traps) shall be installed where determined necessary, in conjunction with the initial grading operations and be maintained throughout the development process to remove sediment fram runoff water draining fram the site undergoing development in order to prevent the degradation of surface water quality.

8. Water nunoff shall be minimized and retained on site where ever possible to facilitate groundwater recharge. The carrying capacity and water quality of the channels immediately downstream shall be considered in determing maximum release rates. Sediment shall be retained on site. 
9. Retention facilites shall use natural topography and natural vegetation, in lieu of, trees and vegetation shall be planted on their broader. on-site facilities shall be properly maintained by the owner such that they do not become nuisances. Nuisance conditions shall include: improper storage resulting in unoontrolled rumoff and overflow, stagnant water with algae growth, insect breeding, discarded debris, safety hazards, and the degradition of ajoining or adjacent surface water qualities.

10. Structures for the control of nunoff shall be dedicated to the Town for maintenance and access easements provided where necessary.

F. Rooftop storage.

1. Rooftop storage shall be desigmed with permanent-type control inlets and parapet walls to contain rumoff on the rooftop. Energency overflow areas shall be provided to insure that the weight of water stored will not exceed the structural capacity of the building

\section{G. Dedication or Fee}

When the town determines that development and construction projects are too small, or engineering asthetics, and economic factors make combined retention or other drainage facilities more practical for construction, the town shall require a fee or equivalent dedication of land which the town shall use to constnuct these facilities. The town may permit several developers to construct joint facilities. The tow shall approve or disapprove the waiver of on-site drainage or retention facilities on the basis of engineering feasibility of a combined facility. The town shall not accept a fee or dedication of land less than (a) the proportionate share for that piece of property in its developed state and $(b)$ the present costs of construction of such drainage or retention facilities.

\subsubsection{Campliance.}

Any person violating any of the provisions of this ordinance or condition attached to the granting of a special exception or variance may be fined not more than two hundred dollars $(\$ 200)$ for each offense. Each day of the existence of the violation, after notification in writing by a Town Official, shall be deemed a seperate offense. The Town official shall notify the Town Solicitor of any violation and the Town Solicitor shall institute appropiate action to abate such violation on behalf of the Town of $x$. Actions for violations may be brought in the District court by the Chief of Police of the Town of $x$ for the imposition of a fine set forth above. 


\subsubsection{Effective Date.}

This ordinance shall take effect upon passage and water quality clasifications shall intiated by the Town Council upon competion of the official map of surface water bodies, streams, wetlands, and rivers and their designated water quality class and the availibilty of such map in the office of the Town Hall.

This ordinanoce shall take effect upon its passage and ordinances or parts of ordinances inconsistent herewith are hearby repealed. The invlaidity of any section or provision of this ordinance shall not invalidate any other section or provision thereof. 
- Watershed Protection District

Section 1. Purpose of District.

A watershed protection district is established in the town of for the following purposes:

a. to preserve and protect the lakes, ponds, streams, brooks, rills, marshes, swamps, bogs, and other water bodies and water courses in the town;

b. to protect, preserve, and maintain the water table and water recharge areas within the town, so as to preserve present and potential sources of water supply for public health and safety;

c. to protect the community from the detrimental use and development of land and waters within the watershed protection district; and

d... to conserve the watershed areas of the town of safety, welfare, and enjoyment of its people.

for the health,

Section 2. Establishment and Definition of District. 
a. The intent of the watershed protection district is to include lands lying adjacent to water courses and surface water bodies which create the catchment or drainage areas of such water courses and bodies, as part of their natural drainage system. The district includes all areas designated on the watershed protection district maps for the town of on file in the office of the Town Clerk, which are hereby made part of the town zoning map(s), plus all land lying within 25 feet from the center line of all brooks, streams and rivers, and within 25 feet from the normal high water line of lakes, ponds, marshes, swamps, and bogs.

b. The watershed protection district is an overlay district and shall be superimposed on the other districts established by this zoning bylaw. No uses not permitted in the portions of the districts so overlain shall be permitted within the district.

Section 3. Permitted Uses.

a. The following uses are permitted within the watershed protection district, subject to Section 4, provided that all necessary permits, orders, or approvals required by local, state, or federal law shall also be obtained:

(1) conservation of soil, water, plants, and wildife;

(2) outdoor recreation, nature study, boating, fishing, and hunting where otherwise Iegally permitted;

(3) boat docks, landings, foot, bicycle and/or horse paths and bridges;

(4) proper operation and maintenance of existing dams, splash boards, and other water control, supply and conservation devices;

(5) residential development, as permitted in the underlying district, with a maximum density of one unit per acre, providing that the average slope of each lot shall not exceed 15\%;

(6) repair, maintenance and reconstruction of structures and uses lawfully existing prior to adoption hereof may be continued as permitted under the zoning act. Existing dwellings may be expanded provided ground coverage is not more than is and

(7) farming, gardening, nursery, conservation, forestry, harvesting, and grazing.

Section 4. Prohibited Uses.

a. The following uses are prohibited within the watershed protection district:

(1) the location of landfills and the storage of salt and road de-icing chemicals;

(2) any building, structure, land-disturbing activities, or excavations within 25 feet from the normal high water line of all water bodies and courses within the watershed protection district;

(3) any animal feedlots, or pastures, or confinement areas, or storage of manure, or drainage from such activities, within 25 feet fron the seasonal high water line of all water bodies and courses;

(4) the disposal of solid waste, other than brush;

(5) the storage and/or sale of petroleum, or any other refined petroleum product, except within the buildings which it will heat; 
(6) the dumping of snow contaminated by de-icing chemicals which is brought from outside the district; and

(7) the storage or disposal of hazardous materials, as defined by applicable state law.

Section S. Special Permit Uses.

a. The Planning Board may allow the following uses, subject to Section 4 , within the watershed protection district, upon issuance of a special permit and subject to any additional conditions the Planning Board (PB) may impose.

(1) those commercial and industrial activities permitted in the underlying district, with a site plan review;

(2) the construction of dams and other water control devices, including the temporary alteration of the water level for emergency or maintenance purposes and periodic cleaning;

(3) ponds or pools or other changes in water bodies or courses, created for swiming, fishing, or other recreational uses, agricultural uses, or drainage improvements;

(4) the application of pesticides for non-agricultural uses in combination with erosion and sedimentation control plans, provided that . all necessary precautions shall be taken to prevent hazardous concentrations of pesticides in the water or the land within the watershed protection district as a result of such application;

(5) residential construction upon a lot with an average slope of greater than 15\%; and

(6) the excavation of gravel, sand, loam, or other earth material. 
$\therefore$ Aquifer Model Ordinance

Section 1. Findings.

The town of finds that:

a. The groundwater underlying this town is a major source of its existing and future water supply, including drinking water;

b. The groundwater aquifer is integrally connected with, and flows into, - the surface waters, lakes, streams, coastal estuaries, which constitute significant recreational and economic resources of the town used for bathing and other water-related recreation, shellfishing, and fishing; c. Accidental spills and discharges of petroleum products and other toxic and hazardous materials have repeatedly threatened the quality of such groundwater reservoir supplies and related water resources in Rhode Island, posing potential public health and safety hazards and threatening economic loss to the communities;

d. Unless preventative measures are adopted to prohibit discharge of toxic and hazardous materials and to control their storage within the town, further spills and discharges will predictably occur, and with greater frequency and degree of hazard by reason of increasing construction, commercial and industrial development, population, and vehicular traffic in the town of

- The foregoing conclusions are confirmed in findings set forth in the Water Quality Management Plan of Rhode Island prepared pursuant to Section 208 of the Federal Clean Vater Act, and by such other pertinent data as may. exist (so listed).

Section 2." Purpose.

The purpose of this Aquifer Protection Ordinance is to protect. public health by preventing contamination of the ground and surface water resources providing water supply to the town.

Section 3. Use Regulations.

Aquifer Protection Zones are hereby created covering the area (descrip- 
by map reference or boundary narrative). Aquifer Protection Zones shall be considered to be superimposed over other districts. Land in an Aquifer Protection Zone shall be subject to the following use restrictions, in addition to those of the underlying district:

a. Prohibited Uses - Within the aquifer protection zone the following uses are prohibited: sanitary landfills, junkyards, municipal sewage treatment facilities with on-site disposal of primary or secondary treated effluent, car washes, road salt stockpiles, dry cleaning establishments, boat and motor vehicle service and repair, metal plating, chemical and bacteriological laboratories, and any other use which involves as a principal activity the manufacture, use, storage, transportation, or disposal of toxic or hazardous materials, except as allowed by special permit below:

b. Special Permit Uses - Within the aquifer protection zone the following shall be allowed only if granted a special permit by the planning board:

(1) Transportation terminals.

(2) Any principal use involving the sale, storage, transportation of fuel oil or gasoline.

(3) Any use involving the retention of less than $f$ of the lot area (typically 10 - 308) in its natural state with no more than minor removal of existing trees and ground vegetation, or rendering impervious more than i of the lot area.

(4) Any use involving on-site disposal of process wastes from operations other than personal hyg.iene and food for residents, patrons, and employees.

(5) Any use (other than a single-family dwelling) with a sewage flow exceeding 10 gallons per $1000^{\circ} \mathrm{sq}$. ft. of lot area or exceeding 15,000 gallons per day regardless of lot area.

(6) Any use involving the generation of toxic or hazardous materials in quanities greater than associated with normal household use. 
vegetation, the existing land use pattern, the water quality impacts of present land uses, existing laws governing land use and water quality, existing and potential water quality problems in the commity, institutional arrangements for implementing land use policies, and most importantly the controls in existence for protecting water quality.

It is also important to mention that planners must incorporate public participation into the planning process for suocess. A cormmity planner must educate and involve the public affected by the land use plan under consideration. This section presents a list of various plamning techniques and zoning techniques which can be adopted for use in Rhode Island cormmities for water quality protection.

Impact Zoning

Large Lot Zoning

Conservation Districts

Growth Management

Preformance Standards

Overlay Districts

Floodplain Zoning

Cluster Zaning

Planned Unit Develogments

Timing and sequence of Growth

Transfer of Development Rights

Iand Acoquisition

Taxation Schemes

Rumoff and Erosion Controls 
$\underline{\text { Road Salts }}$

"More than 500,000 tons of road salt at a direct cost of approximately \$64 million dollars are used during an average winter in New England to keep the roads cleared of ice and snow" (Rhode Island 208 Plan, 1979). The environmental impacts associated with storage and use of road salts are increasing. Dead roadside vegetation is the most visable damage of salts. Salts accumulate in roadside soils, resulting in recuoed permeability and eliminating the fertility of the soil. Rumoff from roadsides can carry the salt into receiving waters where it can be potentially fatal to aquatic organisms. High sodium contents, as noted before, are harmful to people with hypertension and high blood pressure.

Protection measures:

Storage- Store in enclosed structure on impermable surface Store on impermeable surface with curbing covered with impermeable material

Store on impenmeable material covered with sand

Use- Eliminate use

Use salt on severe slopes only, use sand everwhere else Reduce proportion of salt in sand/salt mixture Eliminate salt use in watershed areas 
Erosion and sedimentation

Erosion is the process by which particulate matter is removed from the earth's surface by the runoff of water. Sedimentation is the end result of erosion when the particulate load is finally deposited. sediment has been identified as the prinicpal pollutant from activities such as construction, tillage of soil, dredging, filling, and surface mining. Sediment is a carrier of various pollutants. The most visable aspects of sedimentation is a change of color and increased turbidity in affected waters. Erosion and runoff of sediments can be controlled effectively and economically by proper planning of land disturbing activities. The following planning principals for controlling erosion and sedimentation from the Rhode Island 208 Plan are reocmmended for use by municipal planning bodies:

* The time and area of disturbance of soils which are exposed to rain and runoff should be minimized.

* The graded angle of new slope or fills should be no greater than the original contour of the land.

* Vegetative covers and erosion control devices should be encouraged.

* Avoid long, steep slopes to reduce the velocity of nmoff.

The Rhode Island Erosion and Sediment Control Handbook, 1980, states that if a program for erosion control is worked out during the planning and design stages; the problems brought by soil erosion, 
runoff, and sedimentation can be minimized. The handbook was developed to help muicipal officials develop an understanding of the erosion problems and prepare strategies for controlling erosion and sedimentation. The ordinance for the purpose of controlling erosion and sedimentation contained in this section is recoommended for adoption in municipal communties for the protection of water quality and is contained in the Rhode Island Erosion and Sediment Control Handbook, 1980.

\section{Mitigation Strategies:}

Local commmities can encourage several types of mitigation strategies to be used in land development projects. The following alternatives are availible; vegetative, non-structural, and structural. Each type of alternative will be discussed seperately within this section but a comprehensive strategy would involve the use of all of them.

\section{Vegetative Measures:}

* Temporary vegetation - is established as a cover for exposed soils. Its purpose is to temporarily stablize the soil and recuce damage from wind and water erosion and sediment deposits until permanent stablization is established. Such vegetation should be applied on all exposed soils with the potential for producing sediment and causing on or off site water quality degradation. Easily planned and feasible in all construction areas. 


\section{Chapter I}

\section{1) Purpose}

The City/Town Council finds that the soils and waters of this city/town are finite natural resources that must be carefully managed; that soil erosion and sedimentation continue to be serious problems for the conservation of this city/town's soil and water resources; that soil erosion and sedimentation threaten continualiy to damage the lives and property of this city/town's residents; that shifts in land use from agricultura? and rural uses to non-agricultural and urban uses, construction of housing, industrial and commercial developments, streets, highways, public utilities and facilities, and other land-disturbing activities have accelerated the process of soil erosion and sedimentation, have caused excessive water runoff, have resulted in pollution of this city/town's waters, and have impeded domestic, agricultural, industrial, recreational, and other resource uses. It is therefore declared to be the intent of this city/town to develop and implement an erosion-sediment control program and to require that a 11 applicable land-disturbing activities undertaken within this city/town conform with the provisions of this Ordinance.

2) Definitions

1. Applicant - Any person, partnership, firm, corporation, public corporation, or state, federal, or local agency engaging in a landdisturbing activity within this city/town and subject to the provisions of this Ordinance.

2. Excavation or Cut - Any act by which soil, rock, sand, elay, or gravel is cut into, dug, quarried, uncovered, removed, displaced, or relocated.

3. Erosion - Detachment and movement of soil, sand, rock, clay, or gravel by water, wind, ice, or gravity.

4. Erosion-Sediment Control Plan - A plan formulated in accordance with the Model Plan contained in the latest revision of the Rhode Island Erosion-Sediment Control Handbook, incorporating the erosion-sediment control measures and standards contained in the Handbook and any other measures the erosion-sediment control official deems necessary to control erosion and sedimentation.

5. Land - Any ground, soil, or earth, including marshes, swamps, drainageways, and other areas not permanently covered by water.

6. Land Disturbance or Land-disturbing Activity - Any activity involving the clearing or removal of vegetation; the grading, excavation, cutting, transportation, removal, displacement, or filling of land; any other activity which causes, or has the potential to cause, erosion and sedimentation, with the exception of the construction of singlefamily or duplex dwellings on any lot where the slope is less than 
ten (10) percent and where the land-disturbing activity does not fall within one-hundred (100) feet of any watercourse; gardening for home consumption; normal agricultural operations not involving the clearing of land for new fields; land-disturbing activities conducted on sites for which a Freshwater Wetlands Permit formal application already has been made.

7. Mulching - The application of plant residue or other suitable materials to the land surface for the purpose of retaining moisture, holding soil in place, and aiding in the establishment of plant cover.

8. Land Disturbance Permit - A certificate issued upon the applicant's compliance with the application procedures contained in this Ordinance; the prerequisite for conducting any activity subject to the provisions of this Ordinance.

9. Sediment - Solid material, mineral and/or organic, that is in suspension or has been transported, moved, or displaced while in suspension by air, water, ice, or gravity as the result of erosion.

10. Sediment Basin - A barrier, dam, or other impoundment structure built at suitable locations to retain soil, rock, clay, sand, gravel, sediment, or silt.

11. Soil - All unconsolidated mineral and/or organic material of any origin.

12. Soil Conservation District - A governmental subdivision of this State, and a public body corporate and politic, organized in accordance with Section F, Chapters 2-4, General Laws of Rhode Island.

13. State Conservation Committee - The agency created in accordance with Section 3, Chapters 2-4, General Laws of Rhode Is land.

14. Site - Any plot, tract, parcel, or parcels of land forming the location for any activity subject to the jurisdiction of this Ordinance.

15. Stripping - Any activity by which vegetation, vegetated soil surfaces, or otherwise stable soil surfaces are removed or significantly disturbed, including grubbing, silvicultural, and agricultural clearing operations.

\section{Chapter II}

1) Applicability

This Ordinance shall apply to any situation involving land disturbance as defined in Chapter 1, Section $2(6)$, with the exception of the following:

i) Subdivisions of ten (10) acres or more, or any subdivision of three (3) acres or more where the size of any lot is one-half $(1 / 2)$ acre or less; 
ii) Any development of three (3) acres or more involving a land disturbance of necessarily high intensity; including, but not limited to, shopping centers, parking lots, recreational facilities, industrial and commercial sites, hospitals, and places of worship.

\section{2) Procedures}

A. No land within this city/town shall be disturbed by any person unless such person has obtained a land disturbance permit for each noncontiguous site on which he engages in a land-disturbing activity. Land disturbance permits may be obtained by application and submittal of erosion-sediment control plans to the city/town erosion-sediment control official.

B. The applicant shall submit a separate erosion-sediment control plan for each non-contiguous site. The applicant may consult with the local Conservation District in the selection of appropriate erosion-sediment control measures and the development of the plan. At minimum, each plan shall contain measures for erosion-sediment control based on those described in the latest revision of the Rhode Island ErosionSediment Control Handbook issued by the State Conservation Committee, and shall conform to all of the applicable standards contained in the Handbook. Each plan shall include the following:

\section{NARRATIVE}

i) Project description - Briefly describe the nature and purpose of the land disturbing activity, and the area of grading involved.

ii) Existing site conditions - A description of the existing topography, vegetation, and drainage.

iii) Adjacent areas - A description of neighboring watershed areas such as streams, lakes, residential areas, roads, etc. which might be affected by the land disturbance.

iv) Soils - A brief description of the soils on the site giving such information as soil name, mapping unit, erodibility, permeability, depth, texture and soil structure.

v) Critical areas - A description of areas on the site which have potentially serious erosion problems.

vi) Erosion and sediment control measures - A description of the methods which will be used to control erosion and sediment on the site.

vii) Permanent and temporary stabilization - A brief description, including specifications, of how the site will be stabilized before, during, and after construction. 
viii) Storm water management considerations - A description of the estimated increase in peak rates of runoff and flooding or channel degradation downstream. Also a description of the control structures for management of this storm water.

ix) Maintenance - A schedule of regular inspections and repair of erosion and sediment control structures after each rainfall.

$x$ ) Calculations - Any calculations made for the design of such items as sediment basins, diversions, waterways, or calculations for runoff and soil loss.

\section{SITE PLAN}

i) Vicinity map - A small map locating the site in relation to the surrounding area.

ii) Existing contours - The existing contours of the site will be shown on a map.

iii) Visual conservation - The existing and planned visual effects should be shown, i.e. views, vantage points, anything unique or of historical interest, stonewalls, buildings, etc.

iv) Existing vegetation - The existing tree lines, grassy areas, or unique vegetation.

v) Soils - The boundaries of the different soil types.

vi) Indicate north - The direction of north in relation to the site.

vii) Critical erosion areas - Areas with potentially serious erosion problems.

viii) Existing runoff patterns - The dividing lines and the directions of flow for the different drainage areas and water courses.

ix) Final contours - Changes to the existing contours.

x) Limits of clearing and grading - Areas which are to be cleared and graded.

xi) Location of erosion and sediment control practices - The locations of the erosion and sediment control practices used on the site.

xii) Time schedule - Chronological order of erosion and sediment control measures to be implemented.

xiii) Detailed drawings - Any structure or practice used will be shown in detail on separate drawings and referenced to an overall plan on a site-by-site basis. 
xiv) Responsibility - Have name of person or party responsible for development of plan included.

C. Any revisions of the material required in Section 2, Subsection $B$ of this Chapter must be submitted to the erosion-sediment control official for approval prior to the commencement of any land-disturbing activity.

D. All plans for erosion-sediment control shall be reviewed by the erosionsediment control official, who shall determine whether the applicant's plan(s) complies with the requirements set forth in Section 2, Subsection B of this Chapter. If the erosion-sediment official determines that the applicant's plan(s) complies with the requirements in Subsection $B$, he shall issue the applicant a land disturbance permit. If the erosion-sediment control official determines that the applicant's plan(s) does not comply with the requirements of Subsection $B$, he shall issue a written determination setting forth his reasons for denying the applicant a land disturbance permit. The applicant shall have the opportunity to revise and resubmit his plan(s) so as to comply with Subsection B.

\section{3) Principles and Requirements}

A. General Design Principles: Control measures shall apply to all aspects of the proposed land disturbance and shall be in operation during all stages of the disturbance activity. The following principles shall apply to the soil erosion and sedimentation control plan:

i) Stripping of vegetation, grading, or other soil disturbance shall be done in a manner which wịll minimize soil erosion.

ii) Whenever feasible, natural vegetation shall be retained and protected.

iii) The extent of the disturbed area and the duration of its exposure shall be kept within practical limits.

iv) Drainage provisions shall accomodate increased runoff resulting from modified soil and surface conditions during and after development or disturbance. Such provisions shall be in addition to all existing requirements.

v) Either temporary seeding, mulching, or other suitable stabilization measures shall be used to protect exposed, erosion-prone areas during construction or other land disturbance.

vi) Water runoff shall be minimized and retained on site wherever possible in order to facilitate ground water recharge.

vii) Sediment shall be retained on site.

viii) Diversions, sediment basins, and similar required structures shall be installed prior to any on-site grading or land disturbance. 
ix) Topsoil sha11 be retained on site.

$x)$ Slopes of 10 percent or greater shall be avoided.

B. Maintenance: All required erosion-sediment control measures installed under this Section shall be adequately maintained for one year after the completion of the project or until the erosion-sediment control official determines they are no longer necessary. Upon request, the erosion-sediment control official shall provide the permit holder with a certificate indicating the completion of the required control measures.

4) Appeals

Any land disturbance permit applicant aggrieved by a decision of the erosion-sediment control official not to grant the applicant a land disturbance permit may petition the city/town planning board for a review of the erosion-sediment control official's decision. Upon receipt of such petition, the planning board shall schedule a hearing, at which hearing the chairman of the planning board, or his designee, acting as the hearing officer, shall entertain the applicant's appeal.

If the applicant demonstrates by a fair preponderance of evidence that the erosion-sediment control official erred in determining that the applicant's erosion-sediment control plan(s) did not comply with the requirements of Section 2, Subsection B of this Chapter, the planning board shall order the erosion-sediment control official to issue the applicant a land disturbance permit.

Nothing in this Section shall limit the applicant's right to appeal before a court of competent jurisdiction any decision issuing from an appeal to the planning board.

5) Enforcement

A. Inspections: The erosion-sediment control official is authorized to enter and inspect any site for which any person has made application to the erosion-sediment control official for a land disturbance permit or for which a land disturbance permit has been granted. Any person who willfully impedes or obstructs an inspection by the erosion-sediment control official shall be punished upon conviction by a fine of not more than five-hundred $(\$ 500)$ dollars and/or imprisonment of not more than thirty (30) days.

B. Notice to Cease Operation and Relief in Equity: Whenever any person shall commence any land-disturbing activity as defined in this Chapter without first having obtained a land disturbance permit, the erosion-sediment control official shall have the power by written notice to order the person conducting the land-disturbing activity to cease and desist immediately and/or restore the site to its original state. Any order or notice to restore said site shall be eligible for recordation under Chapter 34-13 of the General Laws of Rhode Island and shall be recorded in the land evidence records of this city/town, and 
any subsequent transferee of said site shall be responsible for complying with the requirements of the order or notice. If said violator and/or subsequent transferee is ordered to restore said site to its original state, and said violator and/or subsequent transferee does not complete such restoration within a reasonable time following the order of the erosion-sediment control official, the official shall have the authority to order the work done by an agent of his choosing, and the person, or agent, or subsequent transferee shall be held liable for the full cost of the restoration.

C. Notice of Permit Violation: Whenever the erosion-sediment control official finds that a project for which a land disturbance permit has been granted is not being conducted in compliance with the conditions on which the permit was granted, the official shall serve upon the permit holder a written notice of permit violation and shall require that the project be brought into compliance with the permit conditions within a reasonable amount of time. If said permit holder fails to comply with the Chief of Land Resources' order, the erosion-sediment control official may revoke the permit and order the person conducting or causing the land-disturbing activity to cease and desist and/or restore the site.

D. Judicial Relief: Nothing in this Section shall prevent the erosionsediment control official from seeking enforcement of any of his duties under this Ordinance or any order issued hereunder before a court of competent jurisdiction.

Whenever the erosion-sediment control official determines that judicial relief is necessary to the performance of his duties under this Act, he may ask the city/town solicitor to file suit on his behalf.

6) Liability of Applicant and Property Owner

Neither having obtained approval of an erosion-sediment control plan, nor compliance with any provision or condition of this Ordinance shall relieve the land disturbance permit holder or the owner of the subject property from responsibility for any damage to persons or property; nor shall approval of any erosion-sediment control plan place upon this city/town any liability for damages to persons or property.

7) Severability

If any provision or requirement of this Ordinance is held invalid by a court of competent jurisdiction, the remainder of this Ordinance shall remain valid. 
* Permanent Vegetation - is established on exposed soils where perennial vegetation is needed for long term protection. Its purpose is to permanently stablize the soil, to reduce damages from sediment and rumoff and to enhance the asthetic enviroment. Such vegetation should be applied on exposed soils that have potential for producing sediment and on or off site water quality degradation. When planning for permanent vegetation measures provisions should be made for surface and subsurface drainage.

* Sodding - stablizes sediment producing and erodible areas by surfacing or covering with cut pieces of turf. Its purpose is to stabilize the area to reduce erosion and sediment damages due to concentrations of surface nmoff or in areas where it is important to establish quick vegetative cover. Can be applied on areas such as gullies, cut and fill slopes 2 to 1 or flatter, and eroding areas.

* Trees, Shrubs, and Ground Covers - can be used for stablizing areas by establishing vegetative cover. The use of such larger vegetation aids in stablizing soil in areas where vegetation other than turf is preferred and to provide food and shelter for wildlife where improved wildlife habitat is desirable. Such vegetation can be used on slopes too steep for mowing, where omamentals are desirable for landscaping purposes, and where wildlife habitat is needed. Trees and shrubs stabilize the soil and prevent erosion, decrease storm water nunoff through canopy interception and root zone 
absorption, provide moderate temperature changes and provide shade, modify the effects of sun and wind, provide visual buffers, screen out noise, filter pollutants from the air and provide oxygen, provide habitat for small animals and birds, preserve and increase property values, and provide desirable aesthetic values. Planning considerations vary widely and must be specific to the types of trees and shrubs desired on the site. Information on plants which can grow locally can be obtained from nurserys, and landscape architects.

* Vegetative Streambank Stabilization - stablizes and protects the banks of streams or excavated channels against soour and erosion. Its purpose is to prevent erosion of the streambank and prevent water quality degradation. This practice can be applied to natural and excavated channels where streambanks are subject to erosion from the action of water, ice, and debris. When planning for such stablization, all state laws and permit requirements must be met. Good planning normally requires staying away from streams and buffer zones surrounding them.

\section{Nonstnuctural Measures:}

* Temporary mulching - is the application of plant residues or other suitable materials to the soil surface. Its purpose is to prevent erosion by protecting the exposed soil surface and to add in the growth of vegetation by conserving availible moisture, controlling weeds, and providing protection against extreme heat and cold. Can be 
applied on areas which have been seeded, areas which cannot be seeded within the seding dates until seeding can be acomplished, and where trees, shrubs, and ground covers do not provide adequate erosion protection. Organic mulches, such as straw, hay, wood chips, bark, and wood fiber are effective and economical. Chemical soil stabilizers or soil binders are less effective as mulches when used alone. These materials are useful to bind or anchor organic mulches to the soil surface. The choice of materials for mulching should be based on soil and site oonditions, season, and economics.

* Permanent Mulctiing - is applying plant residues or other suitable materials that resist decomposition such as wood chips or aggregates to the soil surface where vegatative stablization is either impractical or difficult to establish. Its purpose is to reduce runoff and erosion, prevent soil compaction, conserve moisture, aid in establishing plant cover, and cantrol weds. It can be applied on areas subject to erosion, or which has unfavorable conditions for plant establishment and growth. Should not be used in concentrated flow areas. Wood chips, when combined with tree and shrub plantings, will remove nitrogen from the soil during decomposition. When crushed stane is used as a permanent mulch, a plastic fiber cloth should be placed between the ground and the stane to prevent gemination of weed seeds or other undesirable vegetation. 
* Land Grading - is a reshaping of the ground surface by excavation or filling or both to dbtain planned grades. The purpose of land grading is to prepare suitable sites for coommercial, industrial, residential, and recreational developments. Land grading can be used to improve surface drainage and to control erosion. This measure is practicable where grading to planned elevations is practical for the purposes set forth above. A grading plan for a development should utilize existing topograpghy and natural features as much as possible. This will minimize the degree of land disturbance and avoid extreme grade modifications within a site development. Final slope stability, the impact of the grading operation of adjacent properties and drainage patterns, and its effect on existing vegetation and groundwater resources are a few examples of concerns that should be addressed during planning for land grading.

* Sediment Barriers - are temporary barriers installed across or at the toe of a slope to intercept and retain small amounts of sediment from disturbed or unprotected areas of limited extent. sediment barriers should be used where sedimentation can degrade the quality of receiving waters. Such devices may consist of filter fences, or straw or hay bales, stone berms, or other filter materials. The planmed lifespan of filter barriers varies. Straw or hay bales should only be used as temporary devices. Synthetic fiber fences can be used for langer durations and stone barriers can be used for the langest time. Figures 6,7 , and 8 illustrate hay/straw bale staking, catch basins, and placement of filter fences. 
Figure 6 Placesent and Construction of a Straw Bale Barrier
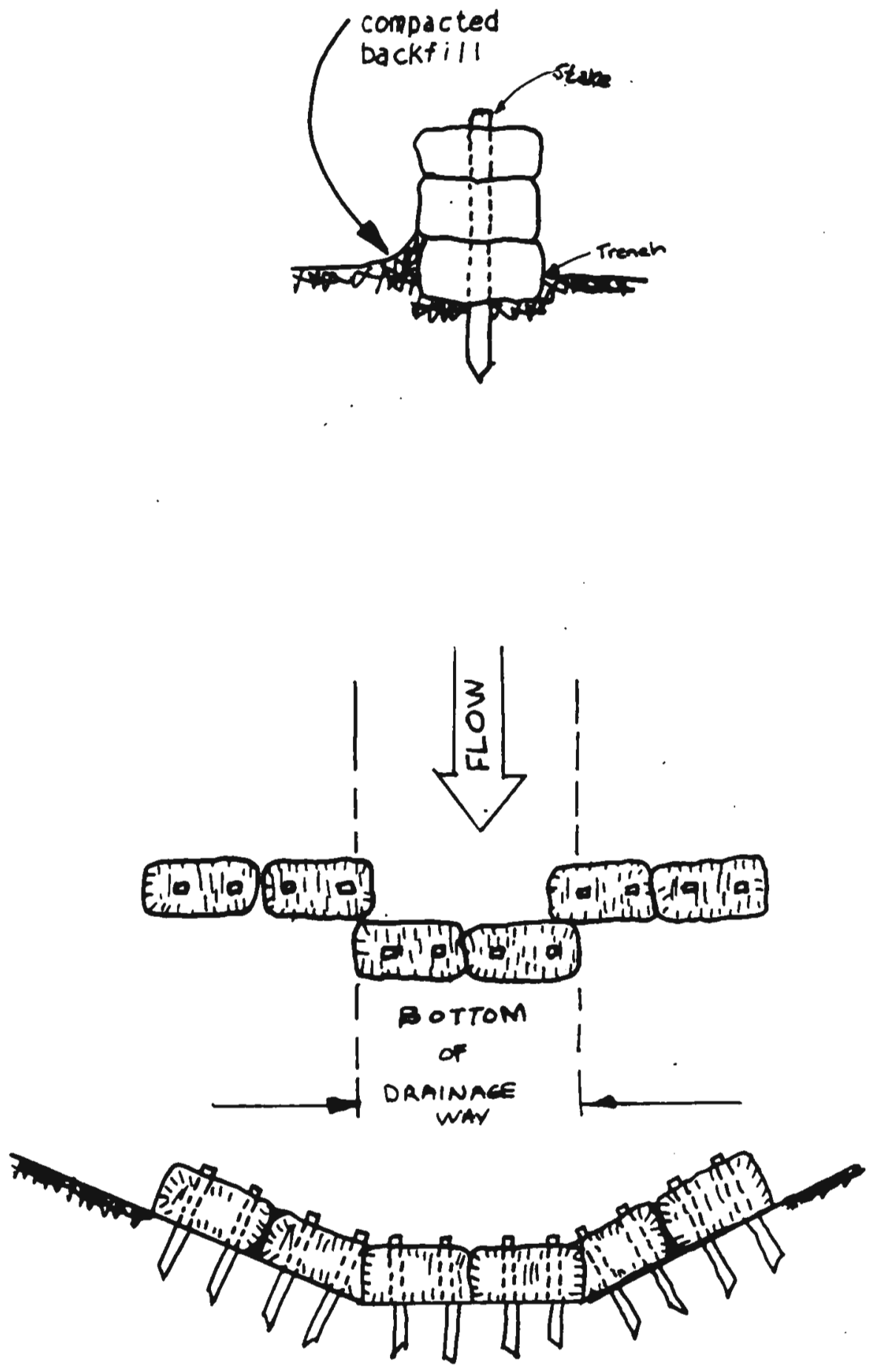
PIGURE 7 Catch Dasins

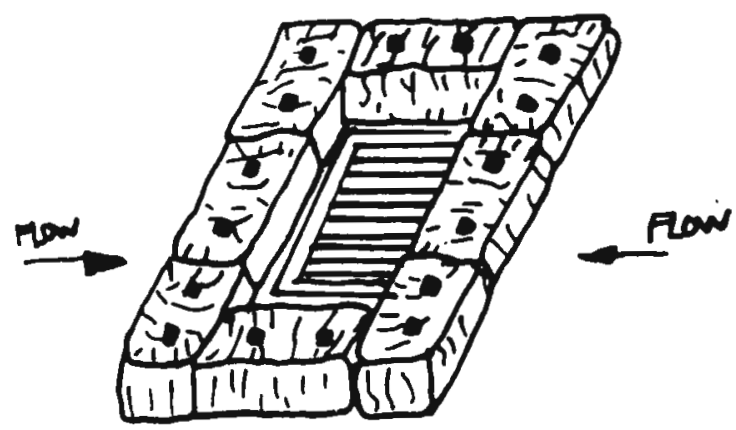

Hay Bale Installation at Storm Sewer Strueturas

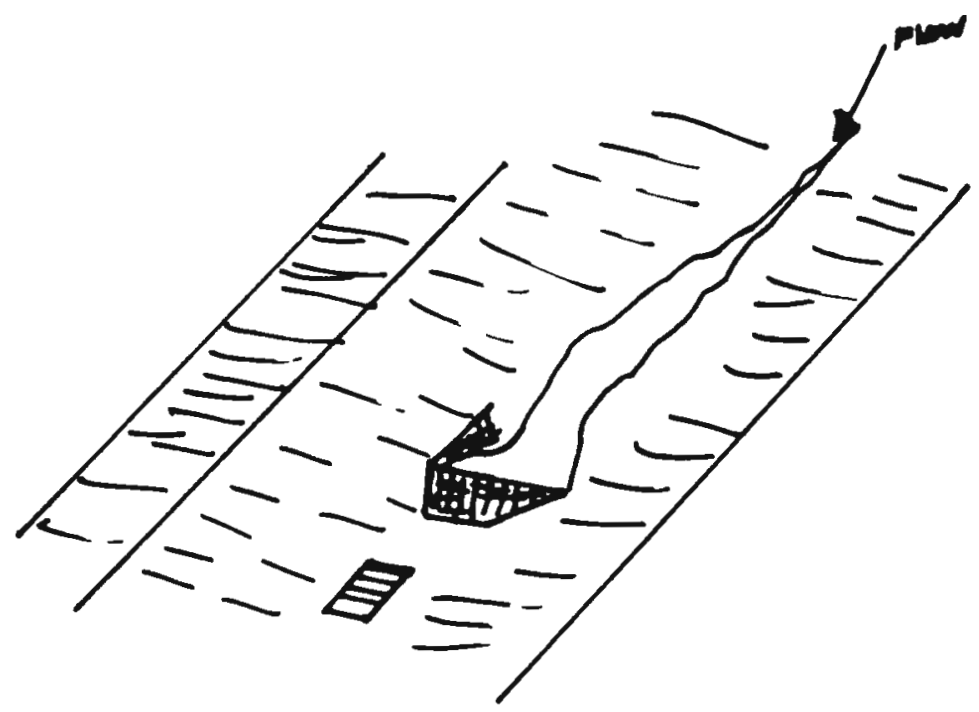

Cath Bains on Slopes 


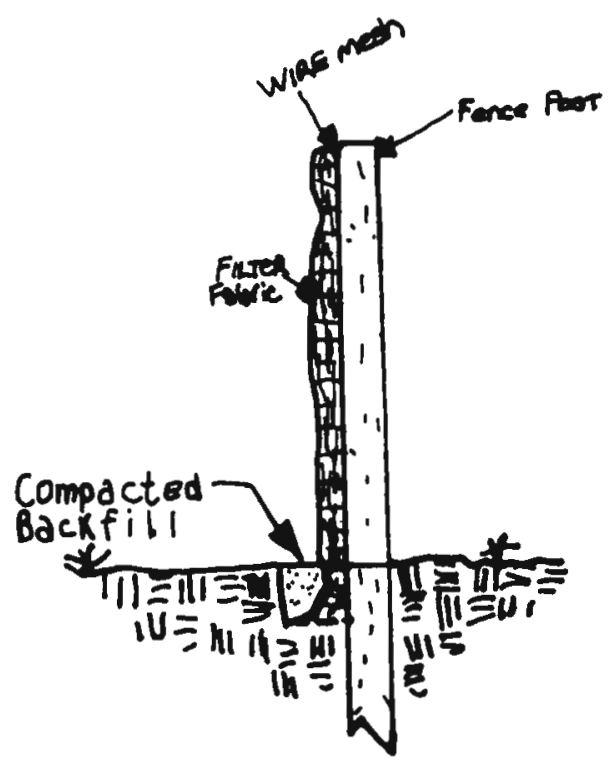

Ficue 8
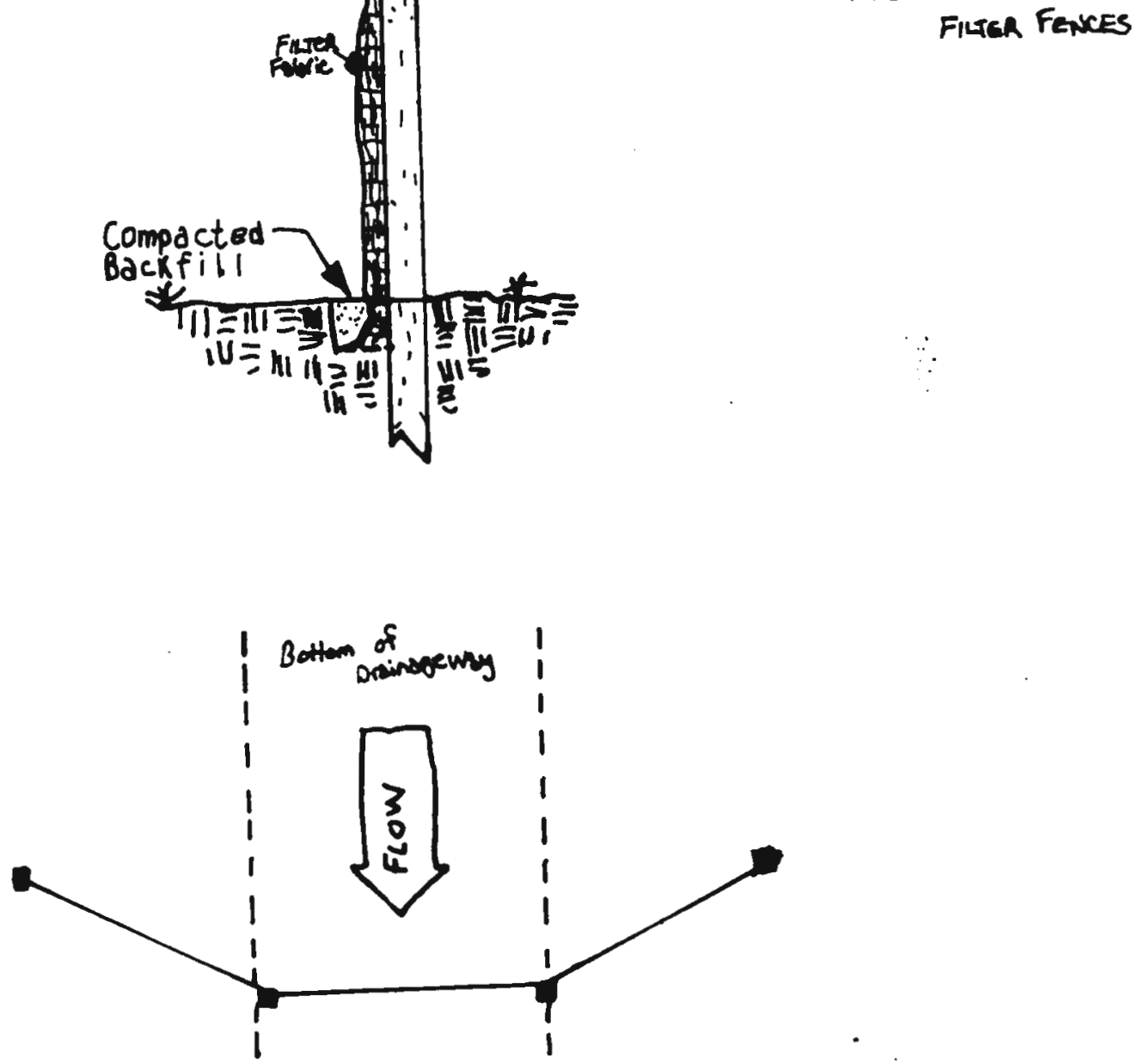

PLAN VIaN

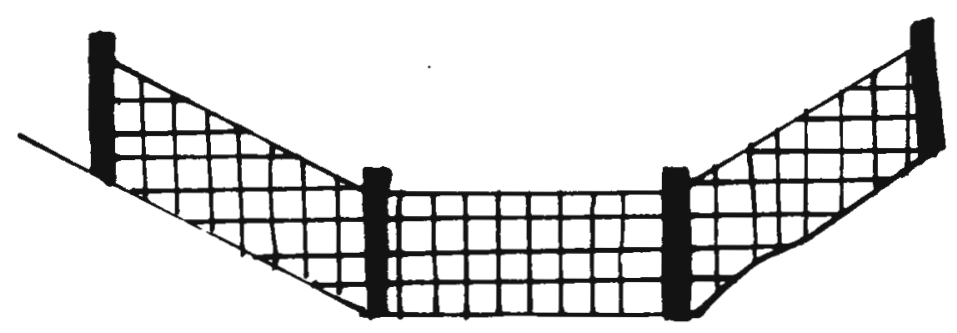

ELEVATION 
Structural Measures:

* Grassed Waterways - are natural or constructed shaped or graded earth materials and stablizied with suitable vegetation for the safe conveyanoe of nunoff water. The puposes of grassed waterways are to provide for the conveyance of excess surface water without damage from erosion, flooding or water quality degradation. This practice applies to sites with drainage areas less than 200 acres where concentrated rumoff requires vegetative protection or stone center lining to control erosion. Vegetation of the waterway should be well established before it is used. The dimensions of the waterway will be based on: the minimm capacity, the channel slope, the maximum permissible velocity, the vegetation, the soil, the ease of crossing and maintenanoe, and site conditions such as the water table, and depth to bedrock.

* Permanent Lined Waterways - have erosion resistant linings of concrete, stone, or other permanent material. The lined section extends up to the side slopes to design flow depth. The earth above the permanent lining shall be vegetated. The purpose of such waterways are to provide for the safe disposal of rumoff from other conservation structures or from natural concentrations of flow, without damage where unlined or grassed waterways would be inadequate. Lined waterways applies to waterways with linings of nan-reinforced, cast in place concrete, flagstone mortared in place, rock riprap or similar permanent linings. Maaximm capacity of the lined waterway flowing at design 
flow should not exceed 200 cubic feet per second. Planning for such structures should consider the primary design considerations of capacity and velocity, lining, land availablity, compatibility with land uses and surrounding environment, safety, and maintenance requairements. Figure 9 shows an illustration of such a waterway.

* Sediment Basins - are barrier, dams, excavated pits, or dugouts constructed across a waterway or at other suitable locations to intercept and retain sediment. Sediment basins purposes are to preserve the water quality in reserviors, to prevent the deposition of solids in streams and rivers, to trap sediment originating from critically eroding areas and construction sites, and to recuce or abate pollution by providing basins for deposition and storage of sand, silt, gravel, and stone. Basins should be designed to provide both detention time for numoff plus the sediment accumulation from the basins total drainage area. Planning considerations for basins are to intercept runoff, minimize disturbance from construction, and to obtain maximum storage benefit from the terrain.

* Detention Basins - are impoundments made by constructing a dam or an inbankment, or by excavating a pit or dugout. Such basins serve the same purposes as sedimentation basins. These basins are used where there is a need to control increased downstream flooding, erosion, or sedimentation due to construction at development sites or from land use changes. The increased downstream flooding, etc., may be caused by increased rumoff volume, increased peak discharge, reduced 


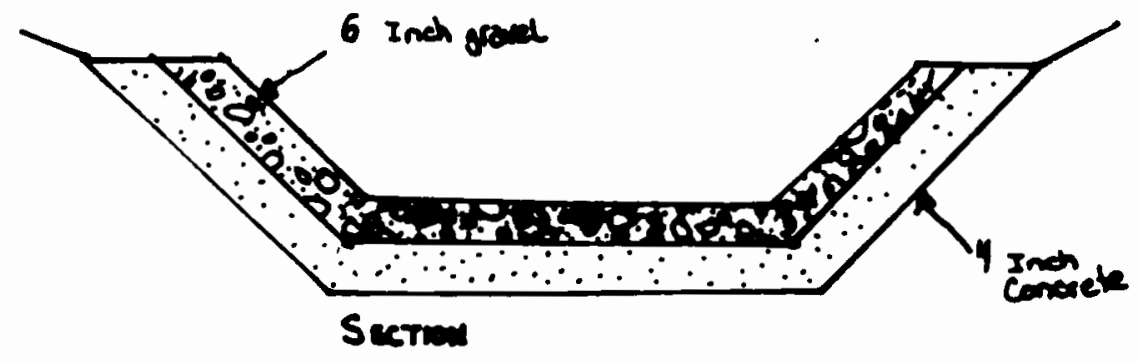

Pigue 9

Premanest Lined watermys

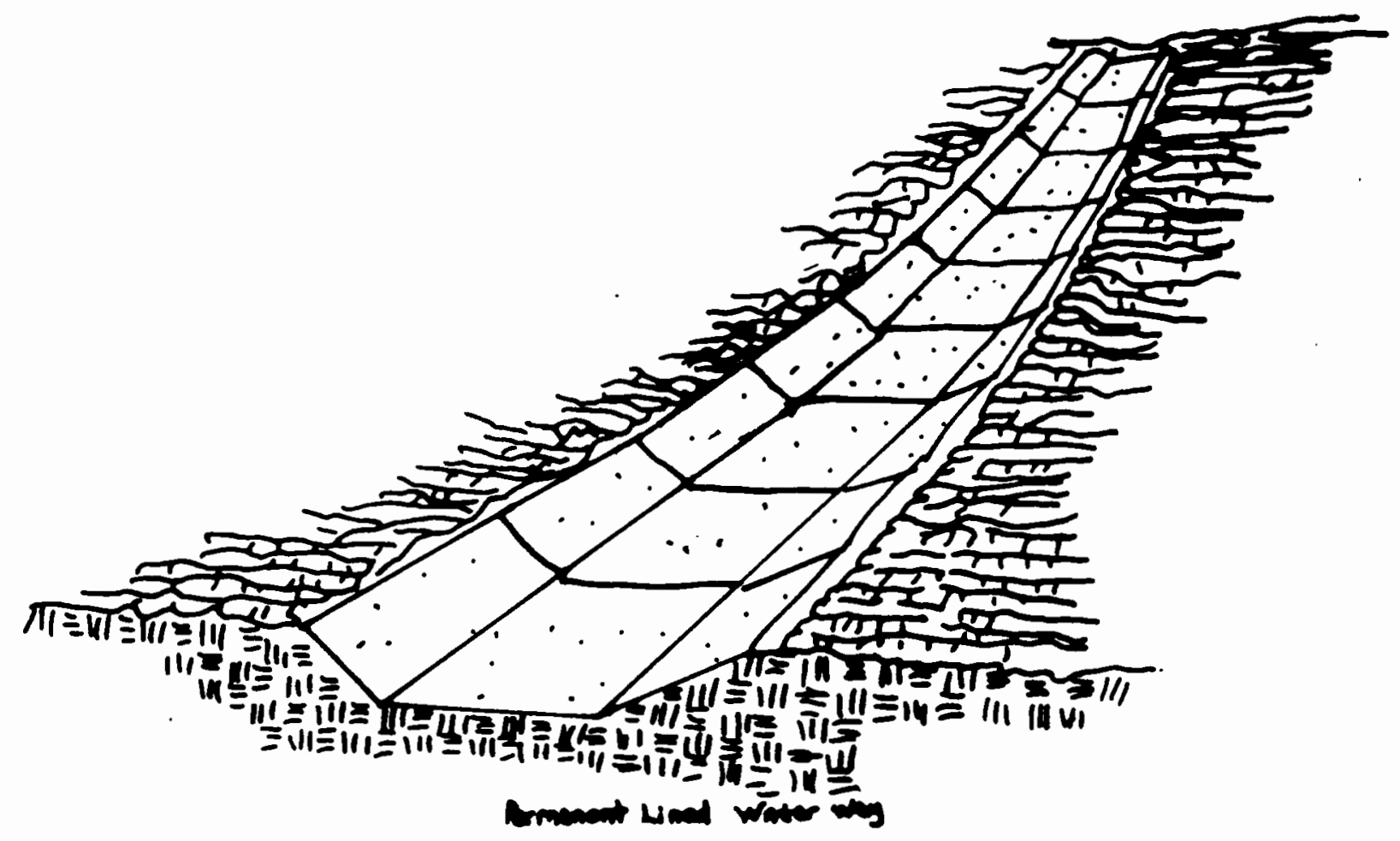


time of concentration, or reduced natural storage capacity. Detention basins may be designed to also function as sediments basins. such basins must be planned to be compatible with the floodplain management programs.

* Riprap - is permanent, erosion-resistant ground cover of large, loose, angular stones. Its purpose is to protect the soil surface from the erosive forces of concentrated rumoff, to slow the velocity of concentrated rumoff while enhancing the potential for groumdwater infiltration, and to stabilize slopes with seepage problems and/or non-cohesive soils. Riprap may be used at storm drain outlets, on channel banks and/or bottoms, roadside ditches, drop structure, at the toe of slopes, and to stablize streams. Riprap is used where erosion potentials are high; construction activities must be sequenced so that the riprap is put in place with the minimim possible delay. Riprap sizes can be designated by either the diameter or the weight of the stones. Graded riprap consists of a vareity of stone sizes. Often riprap canbined with filter blankets can be used. Filter blankets are layers of material placod between the riprap and the underlying soil surface to prevent soil movement into or through the riprap. such filter blankets can be either gravel layers or plastic filter cloths. Figure 10 shows an illustration of riprap stabilization.

* Gabions - are flexible woven-wire baskets composed of rectangular cells filled with stones. Gabions have the same purposes as riprap structures. Gabions can be used in channels, retaining 


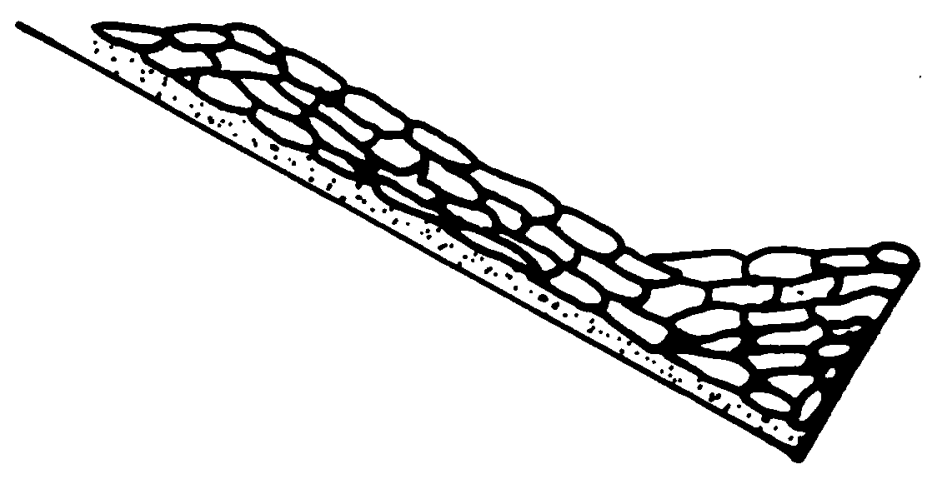

\section{Anar/sLon STABILIAATION}

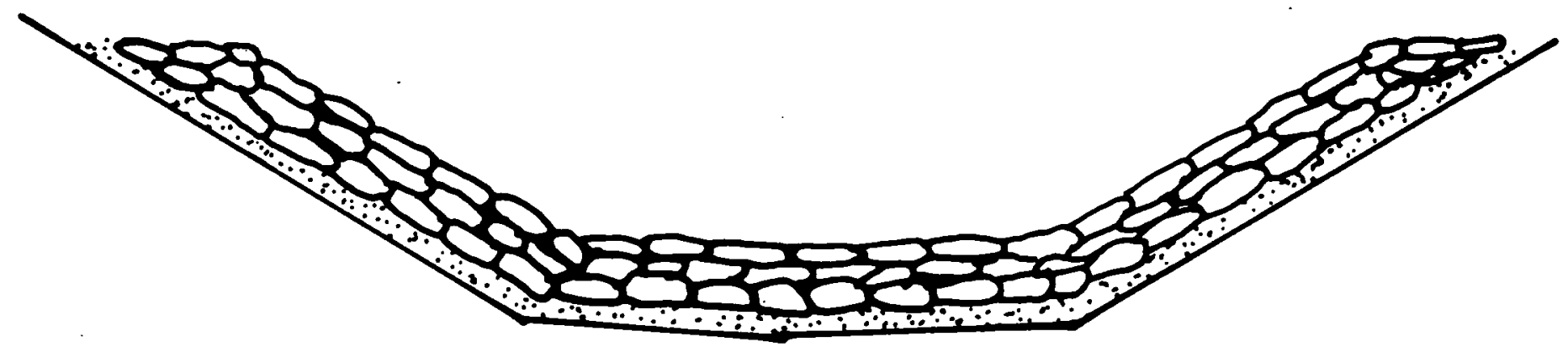

STREAM IHANAKE STABILIZATION 
walls, abutments, check dams, and similar structures. Such devices have much of the same planning considerations as riprap stones and may be used where all the design criteria for riprap has been met, or exposed to exposure from sand or gravel, and the pH of the soil is above 5. Two requirements of gabions are a filter must be used and the stone to fill the cells must be larger than the cell holes. Figure 11 is an illustration of gabions.

* Precast celluar Blociks - These are preceast concrete grids with interspersed void areas. The purposes of such blocks are to protect the soil from the erosive forces of concentrated flows of water, to slow the velocity of nuoff wile enhancing the potential for grouniwater infiltration, and to stabilize slopes with seepage problems and/or non-ochesive soils. Such blocks can be used on channels, slope protection, parking areas and fire lanes. Installation and design shall be in acoordanoe with manufactorer's instructions. Figure 12 illustrates such precast celluar blocks.

* Porous Pavement - This is an asphalt paving material which allows for penetration of water through it and perculation into the soil. Its purposes are to reduce stormater runoff volume and rates from paved surfaces and to allow for natural ground water seepage through infiltration. It can be used on parking lots and driveways where runoff can be excessive and erosive and where an increase in ground water recharge is desired. 


\section{Figure II Gabions}
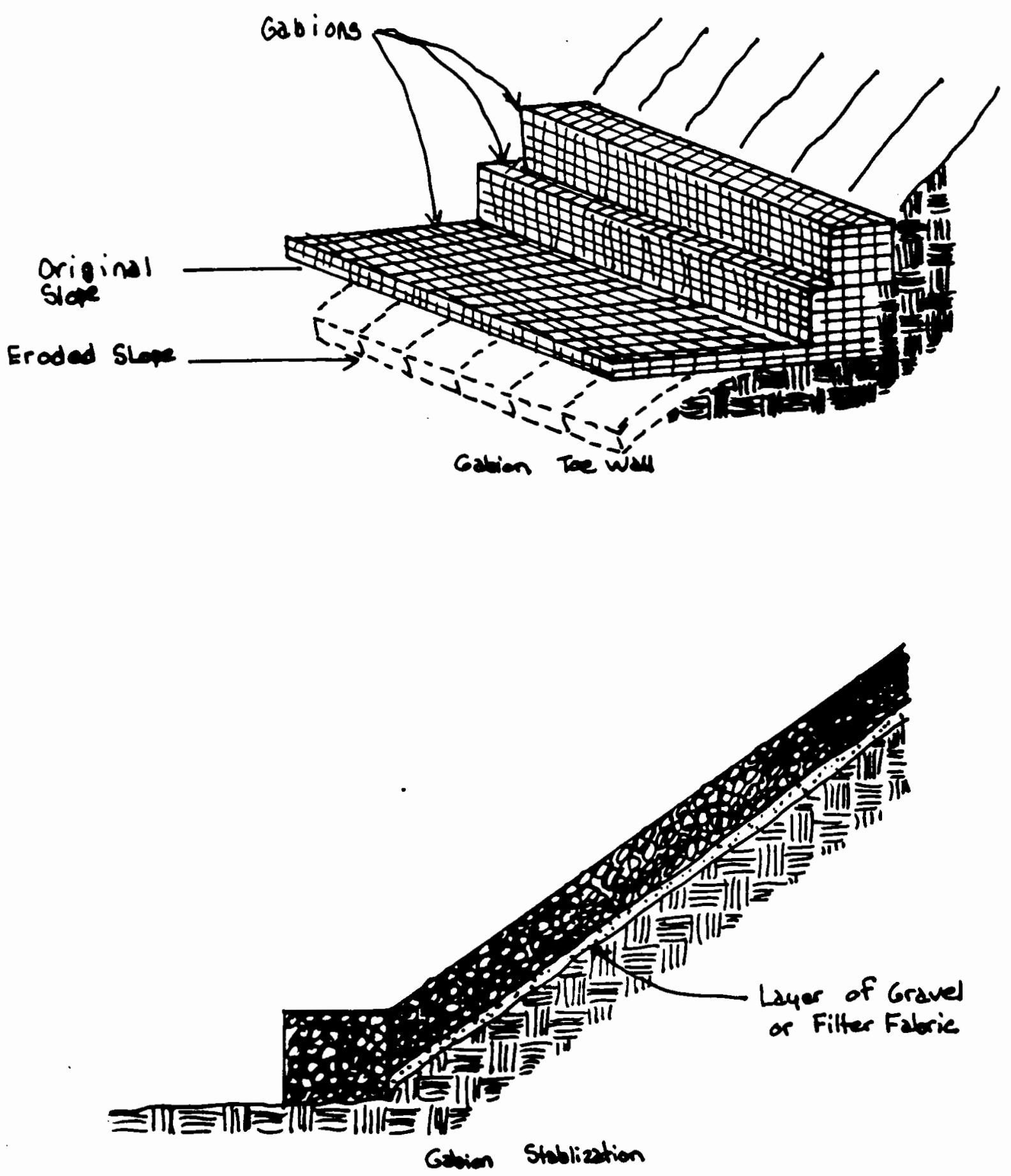
Figure 12 Precast Celluar Blocks

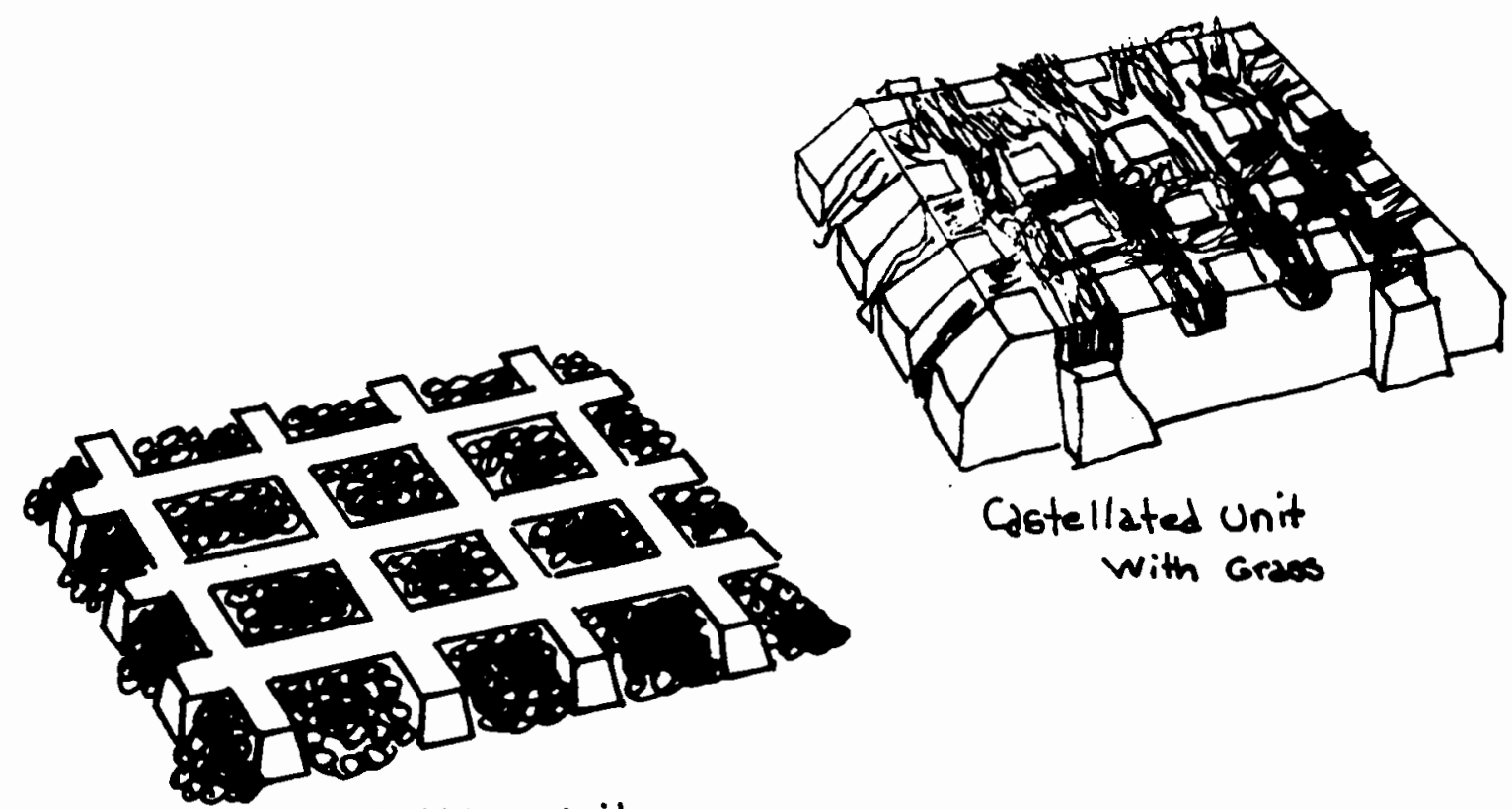

Lattice Unit with Grum

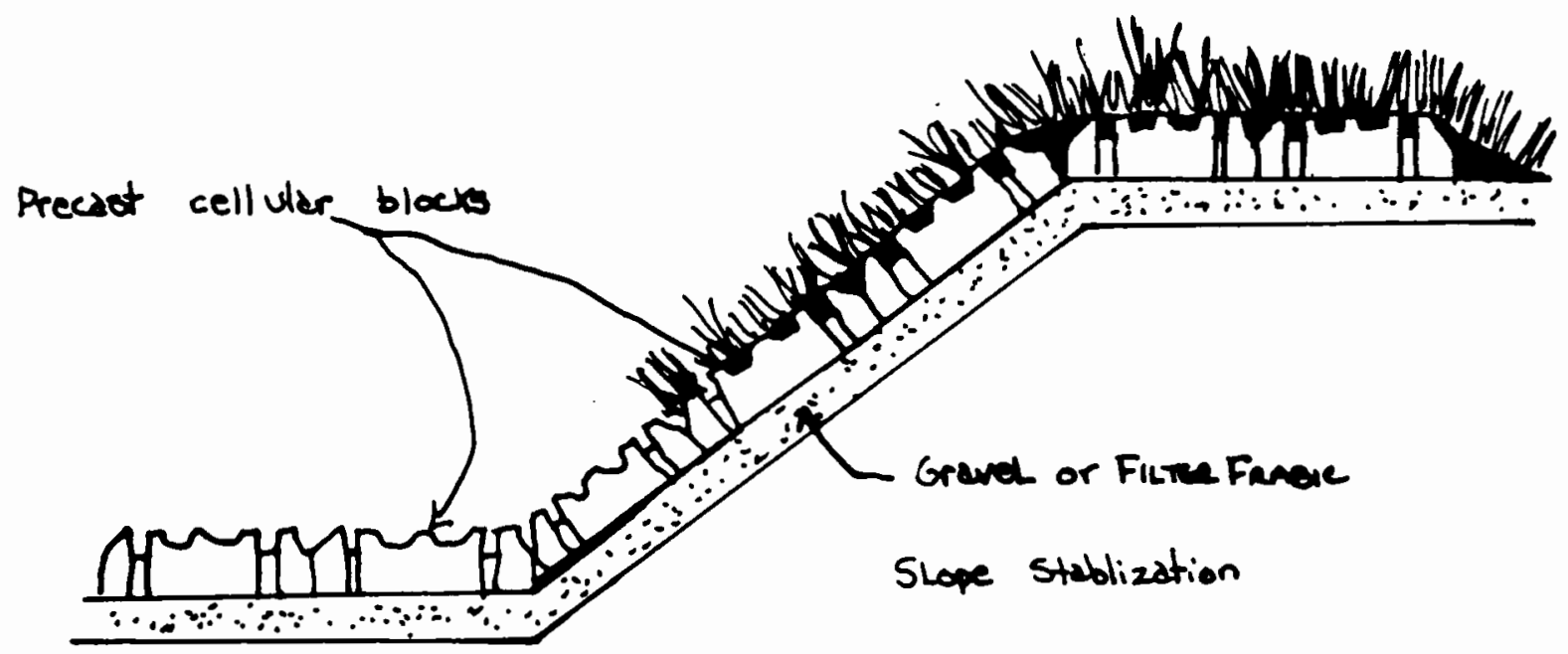


Water Management Planning:

This section presents water quality in the context of varying land uses and the planning idealogies that must be considered in the sphere of comprehensive water planning. Planning considerations for residential, commericial, industrial, recreational, agricultural, fish and wildfife, and asthetics are presented.

Asthetics:

Asthetically pleasing waters add to the quality of the human experience. Water may enhance the visual scene where ever it appears, be it in urban or nural areas. Water may enhance the value of both public and private property and provide a focal point for a comminity. Natural or man-made features may detract from the asthetics. The management of water for asthetic puposes must be planned and executed in the context of the uses of the land, the shoreline, and the water surfaces. People must be the ultimate consideration. Asthetic of water relate to accessibility, perspective, space, and human expectations. The recognition, identification, and protection of the asthetic qualities of water should be the objective of water quality management programs.

\section{Recreation:}

Water quality requirements for recreational purposes may be divided into two categories: (1) general requirements that pertain to all recreational waters; and (2) special requirements more restrictive 
for selected recreation uses of water. Since bathing and swiming involve intimate human contact with water, high water quality standards should be maintained. Swirming waters should be of the highest quality in a cormmity whereas boating waters need not be. Boating is a recreational activity that requires asthetically pleasing waters to enjoy. Boating activities have major impacts on water quality. In areas where it is desired, it is recocommended that power boats be prohibited. The exhaust of engines and oilly discharges can create a displeasing enviroment for nonboaters. A list of possible recreational activities should be prepared for the water resources of the comminity and compare the list to water quality of the supplies. Matching uses and water quality should be encouraged and mismatches discouraged.

Fish and wildlife:

Fish, waterfowl, and other water-dependent wildlife are an integral part of water-based recreation activities and related aesthetic values. The enconomic importance involving the harvest of fish, and shellfish. Pressures placed on the aquatic enviroment by the increasing human population are of a major conoem today. They often lead to disnuption and destruction of life support systens. Maintenance of life support systems for aquatic creatures requires adequately oxygenated water, freedom from toxicants, and the preservation of habitat. It is recommended that high water quality classes needed for contact recreation be maintained for wildlife as well. Zero net runoff is recormended from new development for the 
preservation of aquatic species.

\section{Agricultural:}

Modern agriculture increasingly depends upon the quality of its water to achieve the fullest production of domestic plants and animals. The quality of water detemines productivity and affects the health of the human population exisiting on farms. Farmsteads require water quality at the point of use that is equally equivalent to that demanded by unban populations. Every farm should have a dependable water supply that is palatable and safe for domestic use. Many root crops, fruits, and vegetatbles are washed before leaving the farm for the market. Water for such uses should have the same quality as that for drinking and household purposes. It is recommended that in rural farming areas that groundwater aquifer protection devices be used along with non-point source control measures as previously discussed be implemented as regular agricultural practices. It is recommended that numoff from agricultural areas be controlled as numoff from new development would be controlled.

\section{Industrial:}

Since the industrial revolution, water has been an important factor in industrial processes. Industry uses water for boiler feeding, processing, condensing, and cooling processing. Both steam generation and cooling are encountered under a wide vareity of conditions that also requires a wide range of water quality. Cooling waters are diverse. These waters are usually drawn from large sources 
and are returned to the sources after passing through the cooling process once. The quality of water availible may affect the site location of new industrial plants. Corrosive waters require costly treatment and special handling.

The many industrial processes in use today are vast and the many wastes produced are numberous as well. It is recommended that commities examine the specific type of industries that desire locations and become familiar with its products and processes. Site location should be geared away from enviromentally sensitive areas and areas of water quality with sensitive uses such as swiming. Since industrys range from canning to computer products, incustry specifics must be investigated on a proposal by proposal basis.

\section{Cammercial:}

Commercial uses of water vary with the intensity of the cammercial use. Small commercial uses such as stores and convence goods use much less water than residential la d uses do. Establishments such a resturants require water quality that domestic uses require as well. It is reocommended that proposed commercial uses be examined for potential water use, and the amount of new impervious area it will provide. Required parking areas for commercial establishments often generate a significant amount of increased rumoff than the natural area would generate. It is recocmmended that all commericial development proposals be held to zero net nunoff from the site to mitigate the impact such increased numoff would have on water quality. Porous pavement use should be encouraged. 


\section{Residential:}

Perhaps aut of all uses of water residential uses are the most exhaustive. They also demand the highest quality water as well. Residential water is divided into two categories; (1) private supply, and (2) public supplies. Urban areas draw water from a comman sarroe such as the Sictuate Reservor. In rural areas where no public infrastructure provides public water, individuals obtain water fran private wells. In these areas where no public sewer exists, wastes are disposed of in individual septic systems. It is reocommended that standards be established on a statewide level that would provide a consistent method of locating private wells. A buffer zone, like the buffer zone for septic systems, should be enacted. Subdivisions that incorporate large lots with nunoff controls should be encouraged where public infrastructure is not availible.

In areas of public supplies, water quality, watershed, and aquifer protection ordinanoes, such as the model ones included in this study, should be enacted. Extreme care should be taken to ensure that the surrounding land uses are compatable and do not present health hazards to the general public. Buffer zones" around public water supplies are required by the PuC and should be further adopted at the local level for water quality protection. 
Appendix I

Rhode Island Water Pollution Law

fram the

Enviromental Reporter

Bureau of National Affairs

Washington, D.C. 20037 


\title{
RHODE ISLAND WATER POLLUTION CONTROL LAW
}

\author{
(Rhode Island General Laws, Title 46, Waters and Navigation, Chapter 12 - \\ Water Pollution; Enacted by Rhode Island Public Laws of 1920, Ch. 1914; Amended \\ by PL 1923, Ch. 725; PL 1938, Ch. 634; PL 1956, Ch. 89; PL 1966, Ch. 261; PL 1967, \\ Ch. 198; PL 1970, Chs. 88, 289; PL 1971, Chs. 103, 236; PL 1973, Ch. 207; PL 1974, \\ Ch. 274; PL 1977, Chs. 140, 182; PL 1980, Ch. 239; PL 1981, Ch. 253; PL 1982, Ch. \\ 370; PL 1983, Chs. 149, 182; PL 1984, Ch. 300; PL 1985, Ch. 486)
}

\author{
Administering Agency: Department of Environmental Management \\ Division of Water Supply and Pollution Control \\ 75 Davis Street \\ Providence, Rhode Island 02908
}

46-12-1. Definition of terms. - As used in this chapter the following terms shall, where the context permits, be construed as follows:

(a) The term "pollutant" means dredged spoil, solid waste, incinerator residue, sewage, garbage, sewage sludge, munitions, chemical wastes, biological materials, radioactive materials, heat, wrecked or discarded equipment, or industrial, municipal, agricultural or other waste.

(b) The term "waters" shall include all tidewaters, surface waters including all waters of the territorial sea, all inland waters of any river, stream, brook, pond or lake and wetlands.

(c) The term "ground waters" shall include all underground waters of whatever nature.

(d) The term "person" shall include an individual, firm joint stock company, corporation (including a quasi-government corporation) partnership, association, syndicate, municipality, municipal or state agency, fire district, club, non-profit agency or any subdivision, commission, department, bureau, agency or department of state of federal government (including quași-government corporation) or of any interstate body. (e) The term "pollution" means the man-made or man-induced alteration of the chemical, physical, biological, and radiological integrity of water.

(f) The term "polluting" shall be held to mean the causing of pollution.

(g) The term "director" shall be held to mean the director of the department of environmental management or any subor. dinate or subordinates to whom he has delegated the powers and duties vested in him by this chapter.

(h) Wherever reference is made in this chapter to any order of the director and such order shall have been modified by the court, the order referred to shall be taken to be the order of the director as so modified.

(i) The term "discharge" means the addition of any pollutant, to the waters from any point source.

(j) The term "point source" means any discernible, confined and discrete conveyance, including but not limited to any pipe, ditch, channel, tunnel, conduit, well, discrete fissure, container, rolling stock, concentrated animal feeding operation, or vessel or other floating craft, from which pollutants are or may be discharged. This term does not include return flows from irrigated agriculture. (k) The term "effluent limitation". means any restriction or probibitions, established in accord with the provisions of this chapter or under the Federal Clean Water Act, on quantities, rates and concentrations of chemical, physical, biological, radiological and other constituents which are discharged into the waters.

(1) The term "schedule of compliance" means a schedule of remedial measures including an enforceable sequence of actions, or operations leading to compliance with an effluent limitation or any other limitation, prohibition, or standard.

(m) The term "publicly owned treatment works" means any facility for the treatment of pollutants owned by the state or any political subdivision thereof, municipality or other public entity, including quasi-government corporation.

(n) The term the "Clean Water Act" refers to the Federal Law enacted under 33 U.S.C. $\$ 1251$ et seq. and all amendments thereto.

46-12-2. Administration.

(a) It shall be the responsibility of the director of environmental management to administer this chapter. Within the department of environmental management the director may employ such personnel who shall come within the classified service in 
accordance with the laws of this state for the purposes of this chapter, and may delegate to a subordinate or subordinates any or all the powers and duties vested in him hereunder. The general assembly shall annually appropriate such sums as it may deem necessary for the expenses of administering this chapter.

(b) The department of environmental management is hereby designated as the state water pollution control agency for this state for all purposes of the Clean Water Act, as amended (33 U.S.C. 466), and is hereby authorized to take all action necessary or appropriate to secure to this state the benefits of that act.

(c) The Department of Environmental Management is hereby designated to operate the underground injection control program under the Federal Safe Drinking Water Act, as amended, 42 U.S.C. 300(f), et seq., and is hereby authorized to take all action necessary or appropriate to secure to this state the benefits of that program.

46-12-3. Powers and duries of the direc. 10r. - In addition to the other powers granted him herein, the director shall have and may exercise the following powers and duties:

(a) to exercise general supervision of the administration and enforcement of this chapter and all rules and regulations and orders promulgated hereunder;

(b) to develop comprehensive programs for the prevention, control and abatement of new or existing pollution of the waters of this state;

(c) to advise, consult and cooperate with other agencies of the state, the federal government, other states and interstate agencies and with affected groups, political sub-divisions and industries in the furtherance of the purposes of this act;

(d) 10 accept and administer loans and grants from the federal government and from other sources, public or private, for the carrying out of any of its functions, which loans and grants shall not be expended for other than the purposes for which provided;

(e) to encourage, participate in, or conduct studies, investigations, research and demonstration relating to water pollution and its causes, prevention, control and abatement thereof as he may deem advisable and necessary for the discharge of his duties under this chapter; (f) to collect and disseminate information relating to water pollution and the prevention, control and abatement thereof;

(g) to promulgate standards of water quality adopted by the environmental standards board and to classify the waters of the state accordingly:

(h) to administer state grants to municipalities and political subdivisions for the construction of sewage treatment works:

(i) to hold such hearings, to issue notices of hearings and subpoenas requiring the attendance of such witnesses and the production of such evidence, to administer such oaths and to take such testimony, as he may deem necessary:

(j) To approve, pursuant to standards adopted by the environmental standards boards, the construction, modification and operation of discharge systems or any parts thereof and to require the prior submission of plans, specifications and other data relative to discharge systems and to require that such plans, specifications, or other data be certified by a professional engineer registered in Rhode Island and to inspect such systems either under construction or in operation.

(k) To issue a permit for the discharge of any pollutant or combination of pollutants or to issue a general permit authorizing a category of discharges within a geographical area upon conditions as may be necessary to carry out the purposes of this chapter and of the Clean Water Act which may include, but not be limited to, providing for specific effluent limitations and levels of treatment technology, monitoring, recording and reporting standards, or to deny a permit or general permit;

(l) To renew, revoke, modify or suspend in whole or in part any permit, order or schedule of compliance pursuant to the provisions of this chapter and any rules and regulations promulgated thereunder;

(m) To approve the discharge of pollutants into the waters of this state pursuant to standards adopted by the environmental standards board:

(n) To require publicly owned treatment works to adopt and implement requirements regarding the pretrestment of pollutants consistent with existing federal requirements and to require compliance by all persons with pretreatment requirements; (o) to issue such orders as may be neces sary to prevent the unauthorized construction, modification or operation of disposal systems and the discharge of pollutants into the waters of this state:

(p) to require proper maintenance and operation of disposal systems:

(q) to consult the advisory council on environmental affairs on the policies and plans for the control and abatement of pollution;

(r) to make, issue, amend and revoke reasonable rules and regulations for the prevention, control and abatement of pollution and the enforcement of orders issued hereunder, including public notice and comment requirements;

(s) to exercise all incidental powers necessary to carry out the purposes of this chapter.

(t) To approve the operation of treatment facilities, pursuant to the provisions of chapters 3,11 and 18 of title 44 .

46-12-4. Pollution monitoring system - The director shall establish a pollution monitoring system and a fee system for point source dischargers who discharge sewage into the surface waters of the state. Monies derived from the fee system shall be used by the director to develop and operate a pollution monitoring program. The director shall monitor the levels of conventional and hazardous pollutants especially toxic pollutants discharged into the surface waters and shall assess the impact thereof.

46-12-4.1. Fees - Limits - Recovery of costs. - Such fee established by the director pursuant to $\$ 46-12-4$ shall be based on the individual discharger's need for monitoring and the effluent's potential for environmental degradation as determined by the director; provided, however: that any fees charged discharges shall be in addition to and not substituted for funds appropriated by or monitoring required by the state or federal government for similar purposes; and further provided:

(a) The director shall annually adopt by regulation, in accordance with the provisions of chapter 42-35 of the general laws, the maximum cost of such monitoring program for the next fiscal year.

(b) The operating authority for any publicly-owned treatment facility is hereby empowered to recover any costs incurred under the provisions of this chap- 
ter, includinf administrative costs, by levying an assessment on their customers. Monies derived from the fees shall be deposited into a restricted receipt account for use by the direetor to carry out the requirements of $\$ 46-12-4$ and shall be usable to match any federal funds appropriated for such purposes.

\section{6-12-5. Prohibitions. -}

(a) It shall be unlawful for any person to place any pollutant in a location where it is likely to enter the waters or to place or cause to be placed in any solid waste materials, junk or debris of any kind whatsoever, organic or nonorganic in any waters.

(b) It shall be unlawful for any person to discharge any pollutant into the waters except as in compliance with the provisions of this chapter and any rules and regulations promulgated hereunder and pursuant to the terms and conditions of a permit.

(c) It shall be unlawful to construct or install any industrial, commercial, or other establishment, or make any modification or addition thereto or to undertake any development which may result in the discharge of any pollutant into the waters of the state, unless such discharge is made to a system or means to prevent pollution approved by the director.

46-12-6. Investigation and hearing. If the director sball have cause to believe that any person is violating any provision of this chapter, or any regulation, or order of the department of environmental management adopted in accordance therewith, it shall be his duty to cause such matter to be investigated. At all hearings the direcfor may schedule a hearing, receive evidence and hear witnesses in behalf of the persons believed to be in violation.

The director shall maintain records concerning all investigations undertaken and findings made pursuant to this section. Such records shall be made available for public inspection and shall include the following information: (a) the names and addresses of persons investigated: (b) the date or dates of any hearing or hearings conducted with respect to such persons and the time and place of such hearings: (c) any findings made by the director after the conclusion of such hearings.

46-12-7. Subpoena of witnesses - Enforcement. - All subpoenas shall be served as subpoenas in civil cases in superior court and witnesses so subpoenaed shall be entitled to the same fees for attendance and travel as are provided witnesses in civil cases in superior court. In cases of contumacy or refusal to obey the command of the subpoena so issued, the superior court shall have jurisdiction upon application of the director with proof by affidavit of the fact, to issue a rule or order returnable in not less than two nor more than five (5) days directing such person to show cause why he should not be adjudged in contempt. Upon return of such order, the justice before whom the matter is brought for hearing shall examine under oath such person, and such person shall be given an opportunity to be heard, and if the justice shall determined that such person has refused without reasonable cause or legal excuse to be examined or to answer a legal or pertinent question, be may impose a fine upon such offender or forthwith commit the offender to the adult correctional institutions there to remain until he submits to do the act which he was so required to do, or is discharged according to law.

46-12-8. Expert assistance in investigations and prosecutions. - The director may employ such professional or expert services as he may deem desirable in making any investigation or in conducting any prosecution for the violation of the provisions of this chapter, within the limit of the amount appropriated therefor by the general assembly.

46-12-9. Notices of violation and compllance orders. - (a) The director shall follow the procedures provided in $\$ 42$ $17.1-2(u)$ in issuing any notice of violation or compliance order authorized pursuant to this chapter or any rules, regulations or permits promulgated thereunder.

(b) Where any such order of the director does not specify the system or means to be adopted, the person against whom such order is entered shall, before proceeding to install any such system or means, submit to the director a plan or statement describing the system or means which he proposes to adopt.

46-12-10. Emergency powers. - Notwithstanding any other provision of this chapter, the director upon receipt of evidence that a pollution source or combination of sources is presenting an imminent and substantial endangerment to the health of persons or to the welfare of persons where such endangerment is to the livelihood of such persons, or to protect the environment, may, without prior notice of violation or hearing, take such action as he deems necessary to protect the public health, safety, or the environment. Such actions may include, but shall not be limited to, the following:

(a) Issuing an immediate compliance order stating the existence of the violation and the action he deems necessary. Any order issued under this section without notice and prior hearing shall be effective no longer than forty-five (45) days, provided, however, that for good cause shown such order may be extended one additional period of up to forty-five (45) days; and/or

(b) Obtaining injunctive relief or other order from Superior Court.

46-12-11. Service of orders. - A copy of each order entered by the director shall be sent to the person or persons affected thereby by either certified or registered mail, return receipt requested, by personal service, or by any other form of service now or hereafter autborized in a civil action under the laws of the state.

46-12-12. Modificallon or revocation of order. - Any order of the director may at any time. or from time to time, after at least twenty (20) days notice in writing to the person or persons affected thereby, and after a hearing, if so requested by the affected person or persons, be modified or revoked by an order duly entered by the director.

46-12-13. Civil penalries. - Except as specified in $8 \$ 46-12-26$ and $46-12-27$, any person who shall violate the provisions of this chapter, or of any permit, rule, regulation or order issued pursuant thereto, shall be subject to a civil penalty, of not more than five thousand dollars $(\$ 5,000)$ for 
each day during which such violation occurs.

46-12-14. Criminal penalties. - (a) Except as specified in \$\$46-12-26, and 46-1227 , any person who shall be found guilty of violating, willfully or with criminal negligence, any of the provisions of this chapter, or of any permit, rule or regulation issued pursuant thereto, or an order of the director, shall be punished by a fine of not more than ten thousand dollars $(\$ 10,000)$ or by imprisonment for not more than thirty (30) days, or by both such fine or imprisonment; and every person shall be deemed guilty of a separate and distinct ofiense for each day during which such violation shall be repeated or continued.

(b) Any person who knowingly makes any false statement, representation, or certification in any application, record, report, plan or other document filed or required to be maintained under this chapter or by any permit, rule, regulation, or order issued under this chapter or who falsifies, tampers with, or knowingly renders inaccurate any monitoring device or method required to be maintained under this chapter or by any permit, rule, regulation, or order issued under this chapter, shall upon conviction, be punished by a fine of not more than $\mathbf{\$ , 0 0 0}$ for each instance of violation or by imprisonment for not more than thirty (30) days or by both such fine or imprisonment.

46-12-15. Inspection powers - Rules and regulations. - The director shall have full powers to inspect, and make orders regulating and directing all methods, means and devices employed on any steamer or other vessel in the waters of the state, or at any installation on land, in receiving, carrying, storing, heating. handling or discharging any petroleum. gasoline. kerosene. tar. oil, or any product or mixture thereof: and the director may by order establish all rules and regulations to prevent the discharge or escape of any of said substances into the waters of the state.

46-12-16. Prosecution of violations. The director, without being required to enter into any recognizance or to give surety for costs institute such proceedings in the name of the state. It shall be the duty of the chief counsel of the division of legal services to carry out all such proceedings brought by said director.
46-12-17. Equity proceedings for enforcement. - The superior court for Providence County shall have jurisdiction in equity to enforce the provisions of this chapter and any rule, regulation, permit or order issued pursuant thereto. Proceedings for enforcement may be instituted and prosecuted in the name of the director, and in any such proceedings in which injunctive relief is sought, it shall not be necessary for the director to show that without such relief, the injury which will result will be irreparable or that the remedy at law is inadequate. Proceedings provided in this section shall be in addition to and may be utilized in lieu of other administrative or judicial proceedings authorized by this chapter.

46-12-18. Records of operation. - The director may, by regulation, order, permit or otherwise require any person who discharges to the waters or who discharges to a publicly owned treatment works to:

(a) Establish and maintain such records;

(b) Make such reports;

(c) Install, calibrate, use and maintain such monitoring equipment or methods (including where appropriate, biological monitoring methods);

(d) Sample such discharges (in accordance with such methods, at such locations, at such intervals, and in such manner as the director shall prescribe); and

(e) Provide such other information relating to discharges into the waters or into a publicly owned treatment works as the director may reasonably require.

46-12-19. - Public access to information. - (a) Any permit or permit application, or effiuent data shall be available to the public for inspection and copying.

(b) Other records, reports or information obtained under this chapter also may be made available to the public for inspection and copying; provided that upon a showing satisfactory to the director by any person that such records, reports, or information or any part thereof, except as provided in paragraph (a) of this section, would if made public divulge methods or processes entitled to protection as trade secrets of such person, the director shall consider, treat, and protect such record, report, or information, or part thereof, as confidential; provided, however, that any such record, report, or information accorded confidential treatment may be disclosed or transmitted to other officers, employces, or authorized representatives of this state or of the United States concerned with carrying out this chapter or when relevant in any proceeding under this chapter.

46-12-20. Rules - Proceedings. - In establishing any rule or regulation hereunder or in the conduct of proceedings or in any appeal from an order of the director provided for by this chapter, the provisions of chapter 35 of title 42 shall apply.

46-12-21. Liability. Any person who shall negligently or intentionally pollute ground water shall be liable to any other person who is damaged by such pollution.

46-12-22. Access of enforcement offcers to premises. - The attorney general, the director of the department of environmental management and their agents, while in the performance of their duties, may at all reasonable times enter any premises, buildings, plant or equipment, or other places belonging to, or controlled by any person who is believed to be discharging to the waters or who is believed to be discharging to a publicly owned treatment works, and inspect the same or any part thereof, have access to and copy any records required to be maintained, inspect any monitoring equipment or monitoring method which is required, and have access to and sample any discharges. Any person obstructing, hindering, or in any way causing to be obstructed or hindered the director of the department of environmental management or the attorney general or their agents in the performance of his duties or who shall refuse to permit said directors, the attorney general or their agents entrance into any premises, buildings, plant or equipment, or other places belonging to or controlled by any such person, in the performance of his duties as such, shall be subject to the civil and criminal penalties set forth in 8846 . 12-13 and 46-12-14 of this chapter.

46-12-23. Town and city expenditures for pollution control. - The town council of every town and the city council of every city are hereby authorized to make available sufficient money to pay for the proper control of the pollution of waters in their respective towns or cities and said 
towns and cities may raise any such money by the issue of interest bearing notes of such town or city, which notes shall not be considered in determining whether the indebledness of such town or city is in excess of the statutory limitation: provided. however, that before any notes or any other evidences of indebtedness are issued. any and all plans and specifications for the proper control of the pollution of said waters shall be submitted to and receive the approval of the state department of environmental management.

46-12-24. State grants for pollution prevention focilities. - The director is authorized within the limits of funds made available therefor to make grants to any municipality, intermunicipal agency, municipal sewer district, or state district or agency for the construction of necessary facilities to prevent the discharge of untreated or inadequately treated sewage or other waste into the waters of the state. and for the preparation of reports, plans and specifications required in connection therewith under the following terms:

(a) The grant shall be made only in connection with a project which has qualified for a grant under the Clean Water Act, 33 U.S.C., section 466 et seq., as amended from time to time.

(b) The amount of the grant shall not exceed the sum necessary to assure the recipient of the maximum federal aid it can anticipate qualifying for under the federal act cited in subparagraph (a) hereof.

(c) The plans and specifications for the project must be approved by the director in accordance with section $\$ 6-12-10$ of this chapter.

(d) The grani sidili be inade araslable to the applicant in partial payments on a time schedule similar to that followed by the United States Environmental Protection Agency, the payments to be proportioned in a similar matter.

(e) No grant shall be made for any project until the applicant has made provision satisfactory to the director for assuring its proper and efficient operation and maintenance.

(f) An applicant for a grant must file such executed forms and provide such information as may be required by the direc. tor.

46-12-25. Solid Waste Dispasal Areas. If any person, firm or corporation continuously uses any area for the disposal of solid waste which is located within two hundred (200) feet of any water course then the owner of the land or lessee if leased land where suid area is located must submit to the director of the department of health a written report every sixty (60) days or more frequently if required by the director. The report shall contain among other things the content of dissolved oxygen. the biological oxygen demand. chlorides, iron and coliform bacteria count. from sites tested immediately upstream and downstream of the landfill area at locations prescribed by the director.

46-12-16. Penalty for failure to report. Any person, firm or corporation who shall fail to submit reports as required by section 46-12-25 shall be punished by a fine of four hundred dollars (\$400) per day for each day a report is not filed.

46-12-27. Penalty for falsification $0^{\circ}$ report. - Any person. firm or corporatii:,

who shall falsify any report required by section $46-12-34$ shall be punished by a fine not exceeding four hundred dollars $(\$ 400)$ or by imprisonment of nut more than one (1) bear or both.

46-12-28. Protection of Groundwaters. - Groundwaters shall be and shall be deemed to be waters of the state and shall be protected pursuant to the provisions of this chapter with respect to the following activities, which shall be regulated by the Director in accordance with the provisions of this chapter:

(a) In-ground or surface discharge or disposal of industrial or commercial pollutants.

(b) Nonindustrial and noncommercial subsurface disposal systems only to the minimum extent required to conform to the requirements of the underground injection control program under the Federal State Drinking Water Act, as amended, 42 U.S.C. $300(f)$, et seq.

46-12-29. Liberal construction - Severubilit:. - The provisions of this chapter shall be interpreted and construed liberally in aid of its declared purposes. If any provision of this chapter. or of any rule or regulation issued thereunder, is held invalid by a court of competent jurisdiction. the remainder of the chapter. rulc or regulation shall not be affected thereby. The invalidity of any section or sections or parts of any section or scetions of this chupter shall not atfect the validity of wher sections of this chapter.
46-12-30. Underground storage tank replacement revolving loan fund. There is established a separate fund within the general fund to be called "the underground storage tank replacement revolving loan fund" which shall be administered by the general treasurer in accordance with the same laws and fiscal procedure as the general funds of the state.

46-12-30.1. Legislative findings and intent. - It is the finding of this general assembly that the health, safety, and welfare of many people of the state is being jeopardized by the failure of underground storage tanks and the consequent contamination of private drinking wells and endangering of the public health and safety by the leaking of toxic substances into groundwater and the seepage of toxic fumes that result from such leaks into residences and into the atmosphere. To assist in the replacement of tanks that are leaking or are of an age at which they are found to be statistically likely to leak, or are of a design that has proven to be especially susceptible to leaks is a public purpose that is deserving of remedy. It is, therefore, the intent of this general assembly to establish a fund to be called "the underground storage and replacement revolving loan fund" and that said funds be used to provide the money necessary to remedy leaking underground tanks and tanks that are judged by the director of the department of environmental management to be likely to leak.

46-12-30.2 Definitions. - All definitions and guidelines for replacement of tanks will be developed by the director of the department of environmental management in conjunction with the director's efforts to promulgate regulations for underground storage facilities used for petroleum products and hazardous materials to be promulgated under the authority of chapters $46-12,42-35$, and $42-17$ of the general laws of Rhode Island, 1956, as amended.

46-12-30.3 Underground storage tank replacement revolving loan fund - A. There is hereby created a restricted fund within the general fund to be called "the underground storage tank replacement revolving loan fund" which shall be administered by the general treasurer in accordance with the same loans and fiscal procedures as the general funds of the state. Such fund shall consist of such 
funds as the state may from time to time appropriate, as well as monies received from the repayment of loans by residential owners and by businesses which have been qualified to receive these loans by the director of the department of environmental management, federal grants, gifts, bequests, donations or other funds from any public or private source which monies are intended to replace underground tanks which are leaking or are otherwise eligible for replacement and funding as determined by standards promulgated by the director of the department of environmental management.

B. All monies placed in the fund shall be made available immediately, and are hereby specifically appropriated to the department of environmental management for the purpose of: making low interest loans (at least two points below the six (6) month treasury bill rate as certified by the general treasurer on the effective date of the transaction) to residential and commercial owners of tanks that are declared eligible under rules and regulations promulgated by the director of the department of environmental management.

Loans made under the provisions of this section may be made directly or in cooperation with other lenders or any agency, department or bureau of the federal government or state of Rhode Island. The proceeds received from the repayment of any loans made from this fund shall be deposited in and returned to the underground storage tank replacement revolving loan fund to constitute a revolving fund for the purpose listed above.

46-12-30.4. Administration of the fund. - The department of environmental management shall develop the criteria by rule and regulation necessary for defining eligible projects and recipients and shall prepare and adopt rules and regulations with respect to loan generation, disbursement, payback period, and mortgage convenants.

46-12-30.5. Bonds authorized. - The general treasurer is hereby authorized and empowered, with the approval of the gov. ernor and in accordance with the requirements of law to issue from time to time bonds in the name and behalf of the state and in such amounts as may be specified in an amount not to exceed one million five hundred thousand dollars (\$1,500,000.).

iEdilur's Niste: Sec "Related Laws" in slalc dir l.ilus - 3. al page 501:0101.] 


\title{
RHODE ISLAND WATER QUALITY REGULATIONS
}

\author{
(Rhode Island Department of Environmental Management, Division of Water \\ Resources, Rhode Island Water Quality Regulations for Water Pollution Control; \\ Adopted December 20, 1984; Effective January 9, 1985)
}

1 - Purpose and Goals. It is the purpose of these regulations to restore, preserve and enhance the quality of the waters of the State and to protect the waters from pollutants so that the waters shall, where attainable, be fishable and swimmable, be available for all beneficial uses. and thus assure protection of the public health, welfare and the environment.

2 - Authority. These regulations are adopted pursuant to Chapter 46-12, 42 17.1 and $42-35$ of the General Laws of Rhode Island, as amended.

3 - Severability. If any provision of these rules and regulations or the application thereof to any person or circumstances is held invalid by a court of competent jurisdiction, the remainder of the rules and regulations shall not be affected thereby. The invalidity of any section or sections of parts of any section or sections shall not affect the validity of the remainder of these rules and regulations.

4-Application of these Regulations.

(a) These regulations shall be liberally construed to permit the Department to effectuate the purposes of the State law.

(b) The Department may require an applicant to provide additional informa. tion where such information is necessary, in the opinion of the Department, to fully disclose all relevant facts concerning the application for an Order of Approval or a request for modification of water quality standards, including proprietary data. The applicant may assert a claim of confidentiality. Any failure to submit such information shall constitute valid cause for denial of the application or other remedy as provided by law.

(c) Nothing in these rules and regulations shall be deemed to interfere with the Director's power and duty to issue an immediate order pursuant to subsection 46-12-10 of the General Laws of Rhode Island.

(d) These regulations apply to all waters of the State, all systems or means of wastewater treatment. including sewers, and all discharges into surface waters.

5 - Definitions. Whenever used in these regulations, the following terms shall have the following meanings:

"Administrator" means the administrator of the United States Environmental Protection Agency or his designee.

"Applicable standards and limitations" means all state, interstate and federal standards and limitations to which a "discharge" or a related activity is subject under the Federal or State Acts including effluent limitations, water quality standards. standards of performance, toxic effluent standards or prohibitions, "best management practices," and pretreatment standards under Sections 301, 302, 303, $304,306,307,308,403$ and 405 of the Clean Water Act.
"Best Professional Judgment (BPJ)" means a limitation determined on a caseby-case basis on any pollutant, combination or poilutants or practice(s) which is determined necessary to carry out the provisions of the Clean Water Act and Title 46. Chapter 12 of the General Laws of Rhode Island. "Best Professional Judgment" limitations can be used to set Best Available Technology Economically Achievable. Best Conventional Pollutant Control Technology. Best Practicable Control Currently Available, or "Best Management Practices" limitations as defined in the Clean Water Act either in the absence of an applicable promulgated effluent guideline or where promulgated effluent limitation guidelines only apply to certain aspects of the discharges operation or to certain pollutants.

"Best Management Practices (BMPS)" means schedules of activities, prohibitions of practices, maintenance procedures, and other management practices to prevent or reduce the pollution of waters of the State. BMPs also include treatment requirements, operating procedures, and practices to control site runoff, spillage or leaks. sludge or waste disposal, or drainage from raw material storage.

"CFR" means the Code of Federal Regulations.

"Clean Water Act (CWA)" means the Federal law enacted under 33 U.S.C. $\$ 1251$ et. seq and any amendments thereto. 
"Construction" means any placement, assembly or installation of facilities, equipment or treatment works, site preparation work, including clearing, excavation removal, or modification of existing buildings, structures or facilities which is necessary for the placement, assembly or installation of new source facilities, equipment or treatment works, or entering into a binding contractual obligation for the purposes of facilities or equipment which are intended to be used in its operation within a reasonable time. Options to purchase or contract which can be terminated or modified without substantial loss and contracts for feasibility, engineering and design studies do not constitute a contractual obligation for the purpose of this definition.

"Contiguous zone" means the entire zone established by the United States under Article 24 of the Convention on the Territorial Sea and the Contiguous Zone.

"Depuration" means the transplantation or artificial holding of shellfish for purification purposes.

"Department" means the Rhode Island Department of Environmental Management (DEM).

"Detection limits" means the point at which there are sufficient pollutant constituents present so as to be scientifically measurable. The detection limits shall be those promulgated by EPA (see 49 FR 43234 October 26, 1984), unless the Director determines on a pollutant-by-pollutant basis that advances in analytical methodology allow for further reduction in the detection limits.

"Director" means the director of the Department of Environmental Management or his subordinate or subordinates to whom he delegated the powers and duties vested in him by these regulations.

"Direct discharge" means the "discharge of a pollutant".

"Discharge" means the addition of any pollutant to the waters of the State and includes but is not limited to any spilling. leaking, pumping, pouring, emitting, emptying, dumping or placing of any pollutant where it is likely to enter the waters of the State.
"Discharge of a pollutant" means:

(a) Any addition of any "pollutant" or combination of pollutants to "waters of the State" from any point source", or

(b) Any addition of any pollutant or combination of pollutants to the waters of the "contiguous zone" or the ocean from any point source other than a vessel or other floating craft which is being used as a means of transportation.

This definition includes additions of pollutants into waters of the State from: surface runoff which is collected or channelled by man; concentrations of vessels such as might be found in marinas; discharges through pipes, sewers, or other conveyances owned by a State, municipality, or other person which do not lead to a treatment works, and discharges through pipes, sewers, or other conveyances, leading into privately owned treatment works. This term does not include an addition of pollutants by an "indirect discharger".

"Discharge System" includes any "treatment works" or "facility" and any parts thereof including but not limited to any discharge from a point source.

"Discharger" means any person, corporation, municipality, sewerage authority or other legal entity, who causes, knows of or shoud have reason to know of, or allows, any discharge.

"Effluent limited waters" shall be as defined in paragraph 9.11 of these regulations.

"Effluent limitations" means any restriction imposed by the Director on quantities, discharge rates and concentrations of pollutants which are discharged from point sources into waters of Rhode Island. the United States, the contiguous zone of the ocean. Effluent limitations may include restrictions based on "effluent limitation guidelines" and other criteria pro. vided in the RIPDES Regulations. Effluent limitations for priority pollutants will also be based on one or more of the following indicators of water quality:

(a) RIDEM Ambient Water Quality Guidelines (see Appendix B)

(b) Bioassay test results

(c) In-house data base review and other information related to:
1. aquatic organism toxicity

2. environmental fate

3. human health

4. wildlife habitat

"Effiuent limitation guidelines" means a regulation published by the Administrator under Section 304(b) of the Clean Water Act to adopt or revise "effluent limitations".

"EPA" means the United States Environmental Protection Agency.

"ESB" means the Environmental Standards Board established by Chapter 42 17.3 of the General Laws of Rhode Island of 1956, as amended.

"Facility" means any point source or any other activity (including land or appurtenances thereto) that is subject to regulation under the "RIPDES Regulations".

"Freshwater" means those waters of the State which are not sea water.

"Hazardous substance" means any substance designated under 40 CFR Part 116 pursuant to Section 311 of the Clean Water Act.

"Hazardous waste" shall be defined pursuant to Chapter 23-19.1-4 of the General Laws of Rhode Island of 1956, as amended, and regulations adopted pursuant thereunder.

"High quality water" means water the quality of which is higher than the water quality criteria for the water's designated class, but which does not meet all the water quality criteria for a higher class.

"Indirect discharge" means any person who discharges primarily non-domestic pollutants into a "publicly owned treatment works"

"Low quality waters" means " waters which do not meet their designated water quality standards.

"Margin of safety" means a requirement in addition to specific requirements of these regulations which the director deems necessary to protect the public health and safety and the environment.

"Marina" means:

(a) a dock, pier, wharf, or float, or combination of such facilities, contiguous to a private residence that may accommodate over four vessels; or 
(b) any commercial operation or operation by' a club, city or town which operates a dock, pier, wharf, float or combination of such facilities at which vessels are serviced, stored or kepl.

"Municipality" means a city, town, borough, county, parish, district, quasi-governmental corporation, association or other public body created by or under State law and having jurisdiction over disposal of sewage, industrial wastes, or other wastes, or a designated and approved management agency under Section 208 of the Clean Water Act.

"National Pollutant Discharge Elimination System (NPDES)" means the national program for issuing, modifying, revoking and reissuing, terminating. monitoring and enforcing permits, and imposing and enforcing pretreatment requirements, under Sections 307, 318, 402. and 405 of the Clean Water Act. The term includes any State program which has been approved by the Administrator.

"New discharger" means any building, structure, facility, or installation:

(a) From which there is or may be a new or additional "discharge of pollutants" at a "site" at which on October 16, 1972 it has never discharged pollutants; and

(b) Which is not a "new source": and

(c) Which has never received a finally effective NPDES permit for discharges at that "site". This definition includes an "indirect discharger" which commences discharging into waters of the State after August 13, 1979. It also includes any existing mobile point source (other than an offshore or coastal oil and gas exploratory drilling rig or a coastat oil and gas developmental drilling rig) such as a seafood processing rig, seafood processing vessel, or aggregate plant, that beings discharging at a "site" for which it does not have a permit, and any offshore or cosstal mobile oil and gas exploratory drilling rig or coastal mobile oil and gas developmental drilling rig that commences the discharge of pollutants after August 13, 1979, at a "site" under EPA's permitting jurisdiction for which it is not covered by an individual or general permit and which is located in an area determined by the Director in the issuance of a final permit to be an area of biological concern. In determining whether an area is an area of biological concern, the Director shall consider the factors specified in 40 CFR 125.122(a)(1) through (10). An offshore or coastal mobile exploratory drilling rig or coastal mobile developmental drilling rig will be considered a "new discharger" only for the duration of its discharge in an area of biological concern.

"New source" means any building. structure, facility, site or installation from which there is or may be a "discharge of pollutams", the construction or operation of which commenced:

(a) after promulgation of standards of performance under Section 306 of the Clean Water Act which are applicable to such sources, or

(b) after proposal of standards of performance in accordance with Section 306 of the Clean Water Act which are applicable to such sources, but only if the standards are promulgated in accordance with Section 306 within 120 days of their proposal.

"Permit" means an authorization, license or equivalent control document issued by the Department to implement the requirements of the "RIPDES Regulations" and the Clean Water Act, or previously issued by EPA prior to delegation of the NPDES program to the State of Rhode Island. "Permit" includes a general permit, but does not include any document which has not yet been the subject to final Department action, such as a "draft" or "proposed permit".

"Person" means an individual, trust, firm, joint stock company, corporation (including a quasi-governmental corporation) partnership, association, syndicate, municipality, municipal or state agency, fire district, club, non-profit agency or any subdivision, commission. department, bureau, agency or department of state or federal government (including quasi-governmental corporation) or of any interstate body and any agent or employee thereof.

"Place or discharge pollutants" means to cause or allow pollutants to be discharged, deposited, dumped, spilled, leaked, pumped, poured, emitted, emptied. dumped or placed into the waters of the
State or in any location where it is likely to enter the waters of the State.

"Point source" means any discernible, confined, and discrete conveyance, including but not limited to any pipe. ditch. channel, tunnel, conduit, well, discrete fissure, container, rolling stock, concentrated animal feeding operation, or vessel, or other floating craft, from which pollutants are or may be discharged. This term does not include return flows from irrigated agriculture.

"Pollutant" means any dredged spoil, solid waste, incinerator residue, sewage, garbage, sewage sludge, munitions, chemical wastes, biological materials, radioactive materials, heat, wrecked or discarded equipment, rock, sand, cellar dirt and industrial, municipal or agricultural waste.

"Pretrealment requirements" means any limitation or prohibition quantities. quality, rates, and/or concentrations of pollutants directly or indirectly discharged into or transported by truck or rail or other wise introduced into a publicly owned treatment works that are imposed by federal or state regulation or by public. ly owned treatment works.

"Priority pollutant" means those pollutants listed pursuant to Section 307 (a)(1) of the Clean Water Act (see Appendix B).

"Privately owned treatment works" means any device of system which is (a) used to treat wasted from any facility whose operator is not the operator of the treatment works and (b) not a "POTW".

"Publicly owned treatment works $(P O T W s)^{\prime \prime}$ means any facility for the treatment of pollutants owned by the State or any political subdivision thereof, municipality, or other public entity, including quasi-governmental corporation. This definition includes sewers, pipes if they convey wastewater to POTW as well as any equipment, buildings or machinery used in the treatment operation.

"Recommencing discharger" means a source which recommences discharge after terminating operation.

"Regional Administrator" means the Regional Administrator of the appropriate Regional Office of the Environmental Protection Agency or an authorized representative of the Regional Administrator. 
"Rhode Jsland Pollutant Discharge Elimination System (RIPDES)" means the Rhode Island system for issuing, modifying, revoking and reissuing, terminating. monitoring and enforcing discharge permits and imposing and enforcing pretreatment requirements pursuant to Title 46. Chapter 12 of the General Laws of Rhode Island and the Clean Water Act.

"RIPDES Regulations" means the Rhode Island Discharge Elimination System Regulations promulgated by the Department and any amendments thereto.

"Schedule of compliance" means a schedule of remedial measures included in a permit, including an enforceable sequence of interim requirements (for example, actions, operations, or milestone events) leading to compliance with all applicable State and Federal law and regulations.

"Seawater" means those waters subject to the rise and fall of the tide.

"Severe property damage" means substantial physical damage to property, damage to the treatment facilities which would cause them to become inoperable or substantial and permanent loss of natural resources which can reasonably be expect. ed to occur in the absence of a bypass. Severe property damage does not mean economic loss caused by delays in production.

"Sewage from vessels" means human body wastes and the wastes from toilets and other receptacles intended to receive or retain body wastes that are discharged from vessels, and regulated under Section 312 of the Clean Water Act or under Rhode Island law.

"Sewage sludge" means the solids, residues, and precipitate separated from or created in sewage by the unit process of a "publicly owned treatment works". "Sewage" as used in this definition means any wastes, including wastes from human households, commercial establishments, industries and storm water runoff, that are discharged to or otherwise enter a publicly owned treatment works.

"Site" means the land or water area where any water pollution control facility or activity is physically located or conducted, including adjacent land used in connection with the facility or activity.
"Storm sewer" means a sewer intended to carry only storm water.

"Storm water" means waters which re. sult primarily from surface runoff and includes street wash water and drainage.

"Surface water degradation" shall mean reduction in attained or attainable levels of one or more water quality criteria.

"System or means of wastewater treatment" or "treatment works" means any method, devices or system for preventing. abating, reducing, storing, treating, separating, recycling, reclaiming or disposing of a pollutant, including storm water runoff and sewage or other waste in combined storm water and sanitary sewer systems.

"Treatment works" means any devices and systems used in the storage, treatment, recycling, and reclamation of municipal sewage or industrial wastes of a liquid nature. or necessary to recycle or reuse at the most economical cost over the estimated life of the works, including intercepting sewers, outfall sewers, sewage collection systems, pumping power, and other equipment, and their appurtenances, extensions, improvements, remodeling, additions, and alterations thereof; elements essential to provide a reliable recycled supply such as standby treatment units and clear well facilities; and any works, including site acquisition of the land that will be an integral part of the treatment process (including land used for the storage of treatment wastewater in land treatment systems prior to land application) or is used for ultimate disposal of residues resulting from such treatment. "Treatment works" also means any other method or system for preventing, abating, reducing, storing, treating, separating, or disposing of municipal waste, including storm water runoff, or industrial waste. including waste in combined storm water and sanitary sewer systems.

"Vessel" means every description of watercraft or other artificial contrivance used, or capable of being used, as a means of transportation on water.

"Water quality criteria" means a designated concentration of a constituent that. when not exceeded, will protect an organism, an organismic community or a preseribed water use or quality.
"Water quality standards" means the physical, chemical, biological and esthetic characteristics of a water body as described by State water quality criteria or the water quality which would result from existing discharges under design conditions, whichever is more stringent as determined by the Department.

"Water quality limited waters" shall be defined in paragraph 9.12 of these regulations.

"Waters of the State" or "water" means all surface water and groundwater of the State of Rhode Island, including all tidewaters, territorial seas, wetlands, land masses partially or wholly submerged in water, and both inter- and intrastate bodies of water which are, have been or will be used in commerce, by industry, for the harvesting of fish and shellfish or for recreational purposes.

"Wetlands" means those areas that are inundated or saturated by surface or groundwater at a frequency and duration sufficient to support, and that under normal circumstances do support, a prevalence of vegetation typically adapted for line in saturated soil conditions. Wetlands generally include swamps, marshes, bogs and similar areas.

\section{6. [See page 901:1001]}

7 - Water Quelity Standards and Discharzes.

7.1 Discharges Shall Not Violate Waier Quality Standards - No person shall place or discharge into any waters of the State pollutants which the Director determines would result in the violation of any State water quality criterion assigned to the receiving waters or to downstream waters pursuant to subsection 6.3 and 6.4 of these regulations.

7.2 Discharges Shall Not Further Degrade Low Quality Waters - No person shall place or discharge into any waters of the State pollutants which the Director determines would result in the additional degradation of any water quality criterion of the receiving waters or downstream waters which is already below the water quality standard assigned to such waters.

7.3 Discharges Shall Not Degrade High Quality Waters - No person shall 
place or discharge into any waters of the State pollutants which the Director determines would result in the degradation of any water quality criterion of the receiving waters or downstream waters whose quality is higher than the minimum required by the water quality standards assigned to such waters.

7.4 Class $A$ and SA Waters - No new discharges shall be permitted into Class $A$ or SA waters or into waters designated Class B. C. D, SB or SC which have attained Class A or SA quality. For purposes of this subsection, new discharges shall be construed to include potential direct discharges from POTWs, fixed privately owned treatment systems, industrial

- processes wastes, or wastes resulting from concentrations of vessels such as might be found in marinas.

This subsection shall not apply to:

1. discharges of normal stormwater drainage: and

2. industrial cooling water which the Director determines will not violate water quality criteria for Class A or SA waters.

7.5 Class $B$ and $S B$ Waters - In the case of discharges to Class B or SB waters, the Director may recognize, where appropriate, a limited mixing zone on a case-by-case basis. Due to the potential direct discharge from systems or means of wastewater treatment. mixing zones in Class B waters shall support only Class C uses. However, such discharges must meet the water quality criteria for Class B or SB waters, the requirements of subsection 7.3 for high quality waters and the effluent limitations of Section 8.

This subsection shall not apply to:

1. discharges of normal stormwater drainage; and

2. industrial cooling water which the Director determines will not violate water quality criteria for Class B or SB waters.

\section{8 - Effluent Standards and} Limitations.

8.1 Technology Based Trearment Requirements - In addition to conforming to Section 7 Ambient Water Quality Standards, no person shall discharge into any waters of the State pollutants which the Director determines would not conform to the effluent standards and limitations in- corporated into the NPDES or RIPDES Permit.

8.2 Other Treatment Requirements No person shall place or discharge pollutants potentially containing pathogenic organisms into any waters of the State unless the pollutant has received disinfection treatment prior to discharge.

8.3 Pretreatment - No person shall place or discharge any pollutant into a publicly owned treatment works unless the pollutant has received the pretreatment required pursuant to Section 307 of the Clean Water Act, the rules and regula. tions adopted by the administrator pursuant thereto the Rhode Island Pretreatment Regulations and/or other locally imposed standards.

8.4 Additional Effuent Limitations. Treatment and Pretreatment to Comply with Water Quality Standards - In addition to the other requirements of this Section, no person shall place or discharge pollutants into any waters of the State unless the discharge complies with any additional effluent limitations and receives any additional treatment and pretreatment which the Director determines, pursuant to Section 9, is necessary to comply with Section 7 of these regulations, or to prevent overloading or damaging effects upon a discharge system or means of treatment.

9 - Procedures for Determining Additional Requirement for Effiuent Limitations, Treatment and Pretreatment

9.1 Effuent Limited and Water Quality Limired Segments - In order to determine which waters require additional effluent limitations, treatment or pretreatment to comply with Section 7 of these regulations, or to prevent overload. ing or damaging effects upon a discharge system or means of treatment, the Director shall categorize the waters of the State into effluent limited and water quality limited segments. Such classifications shall be recorded in the Basin Plans required pursuant to subsection 303(e) of the Clean Water Act, and shall be revised as necessary.

9.11 Efficent Limited Waters - Effluent limited waters mean waters for which all pollutants placed or discharged into the waters meet the treatment requirements of Section 8 and will not violate the water quality standards requirements of Section 7. No additional treatment shall be required for the discharge of pollutants into such waters.

9.12 Water Quality Limited Waters Waters where the placement or discharge of pollutants which meet the treatment requirements of subsections 8.1, 8.2 and 8.3 will nevertheless cause a violation of subsection 7.1 and 7.2. In addition to the requirements of 8.1, 8.2 and 8.3, the Director shall further limit or prohibit the placement or discharge of pollutants into water quality limited waters according to the procedure of subsection 9.2 to ensure that no person alone or in combination with other sources, shall cause a violation of subsection 7.1 or 7.2 .

9.2 Wasteload Allocations in Water Quality Limited Waters - For water quality limited segments, the Director shall identify those substances within the discharge which would or do cause a violation of subsection 7.1 or 7.2. The Director shall develop a wasteload allocation for each of these substances. The wasteload allocation shall be based on best available scientific information, technical feasibility of pollutant removal, the relative costs of treatment to the contributing dischargers, and the relative contribution from each source. The Director shall not be required to allocate the full amount of the pollutant specified in subsections 7.1 and 7.2 , but may designate a portion of the allocation as a reserve as he or she deems necessary.

\section{0 - Prohibited Dischargers.}

10.1 General - The prohibitions enumerated in this section apply to all pollutants, regardless of the effect on water quality standards or the treatment which the pollutants receive.

10.2 Pollurion - No person shall place or discharge pollutants into any waters of the State except as in compliance with the provisions of Chapter 46-12 of the Rhode Island General Laws of these regulations. and pursuant to the terms and conditions of a permit (NPDES or RIPDES) or other approval issued by DEM thereunder.

10.3 Storm Water Sewers - No person shall place or discharge pollutants into any 
sewer designed to contain only storm water.

10.4 Urban Runoff - No person shall place or discharge storm water, silty water from construction dewatering efforts, gutter runoff, or street runoff to a treatment works designed to contain only sewage or waterborne industrial waste.

10.5 Hazardous Waste and Hazardous Substances - No person shall place or discharge hazardous waste or hazardous substances into any waters of the State or place or discharge hazardous waste or hazardous substances into a wastewater treatment works, unless such waste has received such pretreatment as the Director or municipality may require under the Rhode Island Pretreatment Regulations.

10.6 Oil. Perroleum Products, Solvenis - No person shall place or discharge oil. petroleum products or industrial solvents into treatment works designed to treat or control only sewage or stormwater unless it conforms with Federal, State and local pretreatment requirements. No person shall place or discharge oil or petroleum products into the waters of the State unless the oil or petroleum products are treated as required by Oil Pollution Control Rules and Regulations, effective 1 September 1957,. as amended.

11 - Areawide Wastewater Management Plan. In addition to the other requirements of these regulations, no person shall place or discharge any pollutant into any waters of the State so as to violate any legally applicable requirements of a plan approved by the Governor of Rhode Island and the administrator pursuant to subsection 208(b) of the Clean Water Act.

\section{2 - Approval and Permits - General} Requirements

12.1 No person shall place or discharge any pollutant into the waters of the State or construct, install, or modify any discharge system including the extension of sewers to an existing sewer system without either having obtained approval from the Director pursuant to Sections 13, 14 and 15 of these regulations or without having obtained, if necessary, an NPDES or RIPDES permit pursuant to the Clean Water Act, Chapier 46-12 of the General Laws of Rhode Island and the RIPDES Regulations.
13 - Application for Approval and Permits

13.1 Application - All persons subject to these regulations shall apply for a RIPDES permit, or a modification to an existing permit, pursuant to the RIPDES Regulations or shall submit to the Director an application for approval for the discharge of a pollutant or for the construction, installation or modification of a discharge system or any part thereof.

13.2 Contents - An application for approval required by Section 13.1 shall be on forms provided by the Director and shall contain such detailed engineering plans and specifications as the Director shall require, including, but not limited to:

(a) Comprehensive engineering report describing the project, basis of design, including design data, and prints of drawings of work project:

(b) Complete specifications of project necessary to supplement prints submitted;

(c) Timetable for the proposed construction or other activity; and

(d) Such additional information as may be requested by the Director to fully assess the impact of the proposed activity upon the waters of the State or to support any changes in scope of project, actual or anticipated.

13.3 Professional Engineer - The engineering plans and specifications required under Section 13.2 shall be certified by a professional engineer registered in the State pursuant to Chapter S-8 of the General Laws of Rhode Island of 1956, as amended.

\section{4 - Procedure for Review.}

14.1 Permits - The procedures for review, approval and appeal of all issues involving a RIPDES permit shall be in accordance with the RIPDES Regulations.

14.2 Review of Application - The Director shall evaluate the design of the proposed discharge system or modifications of or additions to such systems, or any part thereof, according to best engineering practices and on a case-by-case basis. Based on a review of the application the Director may:

(a) Request more information;

(b) Issue an Order of Approval containing such terms, conditions, design modifcations, engineering modifications and op- eration and maintenance requirements as he or she deems necessary to comply with the regulations of the Department, including, but not limited to:

(1) Requirements of additional effiuent limitations, treatment and pretreatment pursuant to subsection 8.4 ; or

(2) Requirements limiting overnight stays aboard vessels in marinas and requiring on shore sanitary and/or shower facilities at such marinas.

(c) Deny the application for failure to satisfy the requirements of Chapter 46-12 or any regulation issued thereunder and advise the applicant of the right to request an adjudicatory hearing pursuant to Section 6.00 of the Administrative Rules of Practice and Procedure for the Department of Environmental Management. The basis of the denial may include, but not be limited to:

(1) The discharge system or any part thereof is likely to render water of the State inaccessible to or uninhabitable for spawning or propagation of native andromous fish; or

(2) The discharge system is overloaded or inadequate to accept and treat any additional load of pollutants in which case the Director, shall, where appropriate, also deny applications for new sewer connections or additional discharges to the system; or

(3) Discharges from vessels in a marina are likely to cause violation of these regulations or any other regulations of the Department; or

(4) The discharge system or any part thereof, is likely to substantially contribute to an increase in non-point source pollution which may result in a violation of these regulations or any other regulations of the Department.

14.3 Automatic Approval - If, within 60 days from the date the initial application was received by the Department, the Director fails to take any action as provided in Section 14.2, then the application shall automatically be approved without any further action by the Department.

\section{5 - Effect of Approval}

(a) The issuance of an approval does not relieve the discharger of the continuing responsibility to comply with Section 7,8 , 9, 10 or 11 of these regulations, of obtaining a Rhode Island Pollutant Discharge 
Elimination System permit as required by Chapter, 46-12 of the General Laws and Regulations adopted thereunder, and of obtaining State certification that the discharge will not violate water quality standards (pursuant to subsections 7.1 and 7.2 of these regulations) or Section 301, 302. 306 and 307 of the Clean Water Act.

(b) The issuance of an approval does not authorize any injury to persons or property or invasion of other private rights, or any infringement of Federal, State or local law or regulations.

\section{6 - Modification of Approval}

16.1 The Director may, after at least twenty days notice in writing to the person or persons affected thereby modify or re. voke an approval for cause, including, but not limited to:

(a) Information indicating that the discharge poses a threat to public health or the environment; or

(b) The existence of a factor or factors which, if properly and timely brought to the attention of the Director, would have justified the application of more or less stringent limitations than required by Section 8 of the regulations, but only if such factor or factors arose after the approval was issued, or

(c) The requirement of more stringent effluent limitations pursuant to Sections 8 or 9 , or alteration of the definition of such limitations in the applicable Environmental Protection Agency regulations; or

(d) Where other circumstances on which the approval was based have materially and substantially changed since the approval was issued, including, but not limited to recategorization of waters from effluent limited to water quality limited or amendment of these regulations.

16.2 Compliance Orders - The Director may include a schedule of compliance in an order modifying a previous order of approval. The schedule shall require the discharger to take specific steps where necessary to achieve expeditious compliance with the modified order. Schedules of compliance shall require compliance as soon as possible.

16.3 Falsification of Information as Grounds for Revocation - The Director may revoke an approval where he determines that the information submitted by the applicant on which basis the approval was issued was false or misleading.

17 - Antidegradation and Upgrading of Water Quality Standards

(a) Any water uses being achieved shall be maintained and protected. Where existing water use classifications specify water uses less than those which are presently being achieved, the Director shall propose to the E S B that it upgrade the classification of the waters in question to reflect the uses actually being attained.

(b) Where high quality water constitute an outstanding National resource, such as waters of National and State parks and wildlife refuges and waters of exceptional recreational or ecological significance, that water quality shall be maintained and protected.

(c) Where the quality of the waters exceed levels necessary to support propagation of fish, shellfish, and wildlife and recreation in and on the water, that quality shall be maintained and protected unless the Director finds, after full satisfaction of the intergovernmental coordination and public participation provisions of the R.I. Continuing Planning Process, that allowing lower water quality is necesary to accommodate important economic and social development in the area in which the waters are located. In allowing such degradation of lower water quality, the Director shall assure water quality adequate to protect existing uses fully. Further, highest statutory and regulatory requirements for all new and existing point sources and all cost-effective and reasonable best management practices for non-point source control shall apply.

18 - Periodic Review and Modificntion of Water Qunlity Standards

18.1 Authority - The Director has the power and duty pursuant to subsection 4612-3(g) of the General Laws of Rhode Island of 1956, as amended, to promulgate water quality standards adopted or modified by the E S B pursuant to 42-17.3.

18.2 Requirement of Periodic Review - Paragraph 303(c)(1) of the Clean Wa- ter Act requires the State at least once every three years to hold public hearings for the purpose of reviewing applicable water quality standards and, as appropriate, modifying and adopting standards. The Director shall hold such public hearings and propose any resulting modificaions to the E S B. The Director shall promulgate such of these proposed modifications which are adopted by the E S B and submit them to the administrator, as required by paragraph $303(\mathrm{c})(2)$ of the Clean Water Act. Such revised standards become water quality standards for the applicable waters of the State.

18.3 General Standards for Conducting the Review - Water quality standards shall protect the public heaith and welfare, enhance the quality of water and serve the purpose of the Clean Water Act. The Director shall take into consideration the use and value of the waters for public water supplies, propagation of fish, shellfish and wildlife, recreational purposes, agricultural, industrial, and other purposes, and for navigation.

The Director shall attempt to establish water quality standards which will result in the achievement of the national water quality goal specified in paragraph $101(a)(2)$ of the Clean Water Act, wherever attainable. In determining whether such standards are attainable for any particular segment, the Director shall take into consideration environmental, technological, social, economic and industrial factors.

The Director shall take into consideration the water quality standards of downstream waters and shall assure that water quality standards provide for the attainment of the water quality standards of downstream waters.

The Director shall adhere to the antidegradation principles of Section 17.

18.4 In waters which do not meet their designated water quality standards, the Director may propose that designated water quality standards be downgraded only where it is demonstrated that attaining the designated use is not feasible because:

(a) Naturally occurring pollutant concentrations prevent the attainment of the use; or 
(b) Natural, ephemeral, intermittent or low flow conditions or water levels prevent the attainment of the use, unless these conditions may be compensated for by the discharge of sufficient volume of effluent discharges without violating State water conservation requirements to enable uses to be met; or

(c) Human caused conditions or sources of pollution prevent the attainment of the use and cannot be remedied or would cause more environmental damage to correct than to leave in place; or

(d) Dams, diversions of other types of hydrologic modifications preclude the attainment of the use, and it is not feasible to restore the water body to its original condition or to operate such modification in a way that would result in the attainment of the use; or

(c) Physical conditions related to the natural features of the water body, such as the lack of a proper substrate, cover, flow, depth, pools, riffies, and the like, unrelated to water quality, preclude attainment of aquatic life protection uses; or

(f) Controls more stringent than those required by Sections 301 (b) and 306 of the Act would result in substantial and widespread economic and social impact.

The Director must also demonstrate that the downgrading will not affect the quality of waters beyond the area in which (a), (b), (c), (d), (e) or (f) applies.

19 - Request for Modification of Water Quality Standards

19.1 Low Quality Waters - Any person may request that the Director downgrade specified low quality waters to the water quality standard actually being attained in such waters. The applicant must specify the water quality criteria which he wishes to be relaxed. Any reclassification of waters by the Director under this sec- tion shall not affect water quality criteria not specified in the request or in the Director's order, pursuant to subsection 7.3 of these regulations.

The Director shall hold a public hearing on every such request that he determines not to be frivolous. At the hearing, the applicant must prove by introducing clear and convincing evidence to the satisfaction of the Director that such a reclassification satisfies the standards of subsections 18.3 and 18.4.

19.2 Disposition of Request - If the applicant carries his burden of proof to the satisfaction of the Director, the Director shall propose the requested reclassification to the E S B for adoption. The Director shall deny requests which do not satisfy subsection 18.3 and 18.4 , as applicable. The Director shall promulgate such modifications as are adopted by the E S B.

19.3 Upgrading - Any person may request that the Director upgrade the classification of a water quality segment. The Director shall hold a public hearing on every such request that he determines not to be frivolous. At the hearing, the applicant must prove by the preponderance of the evidence to the satisfaction of the Director that such a reclassification satisfies the standards of subsection 18.3 or that Section 17 applies.

\section{0 - Variances}

(a) Any person may request a variance from the standards and limitations estab. lished by these regulations except that no variance shall be granted for discharges into waters which:

(1) meet Class A or SA water quality criteria; or

(2) have a use classification of A or SA.

(b) Requests for a variance from those persons holding a NPDES or a RIPDES permit, or applying for a RIPDES permit, shall be reviewed and processed in accordance with Rules $56-59$ of the RIPDES Regulations. All other variance requests, except for those variances which are prohibited in (a) above, may be granted by the Director after public notice and hearing if the applicant demonstrates through clear and convincing evidence that the variance:

(1) will not degrade water quality,

(2) will not significantly alter water uses,

(3) will not have adverse impact on public health and the environment; and

(4) will be consistent with the Coastal Resources Management Council's Coastal Resources Management Program, as amended.

\section{1 - Sampling}

21.1 Water Quality Testing - The latest edition of Standard Methods for Examination of Water and Wastewater, APHA, will be followed in the collection, preservation, and analysis of samples. Where a method is not given, the latest procedures of the American Society for Test Materials (ASTM) will be followed. Other methods recommended by the EPA can be used, if legally acceptable.

Bioassays shall be performed according to the latest edition of Standard Methods for the Examination of Water and Wastewater (APHA), the latest edition of Methods for Measuring the Acute Toxicity of Effluents to Aquatic Organisms (EPA), or other methods if approved by the Director. A more detailed explanation of state requirements pertaining to bioassays is given in Appendix C.

22 - Superseded Rules and Regulations

On the effective date of these rules and regulations, Water Quality Regulations for Water Pollution Control, adopted in 1981 shall hereby be revoked. 


\title{
RHODE ISLAND WATER QUALITY STANDARDS
}

\author{
(Rhode Island Department of Environmental Management, Division of Water \\ Resources; Rhode Island Water Quality Regulations for Water Pollution Control, \\ Section 6 - Water Quality Standards; Adopted December 20, 1984; Effective January \\ 9, 1985)
}

6.1 Purpose. A water quality standard defines the water quality goals of a water body, or portion thereof, by designating the use of uses to be made of the water and by setting criteria necessary to protect the uses. Water quality standards are intended to protect public health or welfare, enchance the quality of water and serve the purposes of the Clean Water Act (the Act) and Chapter 46-12 of the General Laws of Rhode Island. "Serve the purposes of the Act" (as defined in Sections $101(a)(2)$ and 303(c) of the Clean Water Act) means that water quality standards should, whenever attainable, provide water quality for the protection and propagation of fish, shellfish and wildlife and for recreation in and on the water and take into consideration their use and value of public water supplies, propagation of fish, shellfish, and wildlife, recreation in and on the water and agricultural, industrial, and other purposes including navigation.

Such standards serve the dual purposes of establishing the water quality goals for a specific water body and serve as the regulatory basis for the establishment of water-quality-based-treatment controls and strategies beyond the technologybased levels of treatment required by Sections 301 (b) and 306 of the Clean Water Act.

6.2 Water Use Classification - The waters of the State shall be assigned to one of the classes listed below. Each class is defined by the most sensitive, and therefore governing, uses which it is intended to protect:

6.21 Freshwater -

Class A - (drinking) water supply
Class B - public water supply with appropriate treatment - agricultural uses

- bathing, other primary contact recreational activities

- fish and wildlife habitat

Class C - boating, other secondary contact recreational activities

- fish and wildlife habitat

- industrial processes and cooling

Class D - migration of fish

- good aesthetic value

Class E - Nuisance conditions; uses limited to:

- certain industrial processes

and cooling

- power

- navigation

6.22 Sea Water -

Class SA - bathing and contact recreation

- shellish harvesting for direct human consumption

- fish and wildlife habitat

Class SB - shellfish harvesting for hu-

-man consumption after dupuration

- bathing, other primary contact recreational activities

- fish and wildlife habitat

Class SC - boating, other secondary contact recreational activities

- fish and wildlife habitat

- industrial cooling

- good aesthetic value

6.3 Water Quality Criteria - The following physical, chemical and biological criteria are parameters of minimum water quality necessary to support the water use classifications of subsection 6.2 and shall be applicable to all waters of the State.
6.31 General Criteria - The following minimum criteria are applicable to all waters of the State, unless criteria specified for individual classes are more stringent:

1. At a minimum. all waters shall be free of pollutants in concentrations or combinations that will:

(a) Adversely effect the composition of bottom aquatic life;

(b) Adversely effect the physical or chemical nature of the bottom:

(c) Interfere with the propagation of fish and shellfish; or

(d) Undesirably alter the qualitative and quantitative character of the biota.

2. Aesthetics - All waters shall be free from pollutants in concentrations or combinations that:

(a) Settle to form objectionable deposits:

(b) Float as debris, scum or other matter to form nuisances;

(c) Produce objectionable odor, color, taste or turbidity; or,

(d) Result in the dominance of nuisance species.

3. Radioactive substances - The level of radioactive materials in all waters shall not be in concentrations or combinations which would be harmful to human, animal or aquatic life, or result in concentrations in organisms producing undesirable conditions.

4. Nutrients - Nutrients shall not exceed the site-specific limits necessary to control accelerated or cultural eutrophication and 
Best Management Practices shall be used oceans, the limits of mixing zones will be to control sedimentation and erosion.

5. Thermal Mixing Zones - In the case of thermal discharges into tidal rivers or estuaries, or fresh water streams or estuaries, where thermal mixing zones are allowed by the director, the mixing zone will be limited to no more than $1 / 4$ of the cross sectional area and/or volume of flow river, stream or estuary, leaving at least $3 / 4$ free as a zone of passage. In wide estuaries and established by the director.

6. Non-thermal Mixing Zones - In applying these standards the Director may recognize, where appropriate, a limited mixing zone or zone of initial dilution on a case-by-case basis. The locations, size and shape of these zones shall provide for the maximum protection of aquatic resources.

At a minimum, mixing zones must:

(a) Meet the criteria for aesthetics; (b) Be limited to an area or volume that will minimize interference with the designated uses in the segment;

(c) Allow an appropriate zone of passage for migrating fish and other organisms; and

(d) Not result in substances accumulating in sediments, aquatic life or food chains to exceed known or predicted safe exposure levels for the health of humans or aquatic life.

\subsection{Class-Specific Criterla - Fresh Waters}

Criterion

Dissolved oxygen

Sludge deposits-

solid refuse-

floating solids-

olls-grease-scum

Color and turbldity None other than of natural origin. Not to exceed 5 Jackson Units (5 JU).

Collform bacterial $100 \mathrm{ml}$

Fecal collform bacteria/100 $\mathrm{ml}$

Taste and odor

\section{Class A*}

$75 \%$ saturation, 16 hours/day, but not less than $5 \mathrm{mg} / 1$ at any time.

None allowable.
Class $B$

$75 \%$ saturation, 16 hours/day, but not less than $5 \mathrm{mg} / \mathrm{l}$ at ony time.

None allowable.

None in such concentrations that would impair any usages spectfically assigned to this class. Not to exceed $10 \mathrm{JU}$.

Hot to exceed a median value of 1,000 , and not more than $20 \%$ of the samples shall exceed a value of 2,400 .

Hot to exceed a median value of 200 , and not more thap $20 \%$ of the samples shall exceed a value of 500 .

None in such concentrations that would impair any usages spectfically assigned to this Class nor cause taste and odor in edible portions of fish.
Class C

\section{Class 0}

Minimum $5 \mathrm{mg} / 1$ any time. A minimum of $2 \mathrm{mg} / 1$ Normal seasonal and di- at any time. urnal varfations above $5 \mathrm{mg} / \mathrm{l}$ wifl be maintained.

Sludge deposits, flosting solids, ofls, grease and scum shall not be allowed except for such small amounts that may result from the discharge of appropriately treated sewage or industrial waste effluents.

None in such concentrations that would Impair any usages spectfically assigned to this class. Not to exceed $15 \mathrm{JU}$.

Hone in such concentra. tions that would Impatr any usages spectfically assigned to this Class.

Not appifcable.

Nlone in such concentrations that would impatr any usages specifically assigned to this Class.

Mone in such concentrations that would tmpair any usages spectftcally assigned to this Class.

Not applicable.

None in such concentrations that would impair any usages speciffcally assigned to this Class nor cause taste and odor None in such concentrations that would impair any usages speciffically assigned to this class. 
6.32 Class -Specific Criterie - Fresh Waters (Cont'd).

Criterion

plt

\section{Allowable}

temoerature

increase

\section{Closs A*}

As naturally oceurs.

Hone other than of nacural origin.
Class a

$6.5-8.0$ or as natu. rally occurs.

Only such Increases that will not impair any usaoes specifically as signed to this Class.".

\section{Class C}

$$
6.0-8.5
$$

Oniy such Increases that will not imnair any usages specifteally assigned to this Class or ciuses the growth of unfavorable soectes of biota.

\section{Class 0}

$6.0 \cdot 9.0$

Mone except where the Increase will not exceed the rec. ommended IIntes on the arost sensitive water use and in no case exceed 900F.
Chenicsl constituents

a. Maters shall be fres from chemical constituents in concentrations or combinations which could be harmful to humin, animal, or couatic life for the appropriate nost senstitre and governing water class use or untavorabiy al ter the blota.

b. If an aquatic toxiclty value has not been estabilished in the R.I. OEH Ambient Mater Quality Guidelines (see Appendix B), then the level of any "priority pollutant* (sec-Appendix 8) shall not exceed the "detection limits" in the ambient water unless the discharger dewonstrates to the satisfaction of the Director that a higher concentration will not adversely effect the most sensftive use of the water body.

The 1 intes preseribed by the United States Environmental Protection Ageney will be used where not suberseded by more stringent state requirements.
The ambient concentration of a pollutant in a water body desl grated as sultable for fish and/or wildlife habttat shall not exceed the Anbtent Mater Quality Guidelines. (see Appendix B) for the protection of aquatic organisms from chrenic effects. unless the chronis guideline is modified by the oirector based on results of bloassay test: conoucted in accordaree with the terms and conditlons provided in Appendix $C$.
The ambient concentration of a pollutant In a water body designated as suttable for fish migration shall not exceed the R.1. DEM Amblent Hater Ouality Guldelines (see Appendix B) for the protection of aouatle organisms iron acute effects. uniess the acute guldel tne is modified by the Director based on resuits of blosssay tests conducted in accordance with the terms and conditians provided in Appendiz $C$.

Phosphorus

None in such concentration that would impair any usages speciflcally assigned to said Class. New discharges of wastes containing phosphates will not be permitted into or immedlately uostream of lakes or ponds. Phosphates shall be removed from existing discharges to the extent that such removal is or may become technically and reasonably feastble.

Class A waters in use for drinking water supply may be subject to restricted use by state and local authorities.

Guldeline, pending further research.

The temperature Increase shall not raise the temperature of the receiving waters above the reconnended $l$ imit on the most sensitive recefving water use and in no cases exceed 83 degrees $F$. In no case shall the temperacure of the receiving. woter be raised wore than 4 degrees $F$. Heated discharges into designated coldwater habitats shall not raise the temperature above 68 degrees $F$ outside an established thermal mixing zone. 


\subsection{Class-5pecific Criteria - Sea Waters}

\section{Criterion}

Dissolved oxygen

Sludge deposits solid refuse-

floating solids.

oils-grease-scum

Color and

turbidity

Coliform bacteria per $100 \mathrm{ml}$

Tecal colifor bacteria/100 ml

\section{Class SA}

Not less than 6.0

mo/l at uny time.

None llowable

shall ordinarily exceed an RTN of 230 for a 5-tube decimal dilution or $: 330$ for a 3-tule decimal

dilution.

Mbt to exceed a median valive of 15 and not more than 10 t of the sasples slall exceed a value of 50."
None allowable

None in such concentrations that would impair eny usages specifically assigned to this Class.

Not to exceed a wedian value of 700 , and not mare than 108 of the sauples shall exceed a

value of 2300 .

Not less than 5.0

$\mathrm{mg} / 1$ at any time.

Not to exceed a median -value of 50, and not more than 101 of the samples shall exceec a value of 500."

\section{Class SC}

Not less than $5 \mathrm{mg} / \mathrm{l}$ during at least 16 hours of any 24-hour period not less than $4 \mathrm{mg} / 1$ at any time.

None except thot anount chat may result frow the discharge frow mste treatment facility providing appropriate treateent.

None in such concentrations that would impair any usages specifieally assigned to this Class.

None in such concentrations that would impair amy usages specifically essigned to this Cass. 
- Criterton

Taste and odor

\section{Class $5 A$}

None allowable

pH

Temperature increase:

Chemical constituents

\section{$6.8-8.5$}

\section{Class 5B}

None in such concentrations that would impair any usages spectfically assigned to this class and none that would cause taste and odor in edible flsh or shellfish.

\section{Class SC}

Mone In such concentrations that would tmpatr any usages speefflcally ass igned to this Class and none that would cause taste and odor in edible fish or shell. fish.

$$
6.8-8.5
$$

\section{$6.5-8.5$}

None except where the increase will not exceed the recommended 11 mit on the most sensitive recelving water use and in no case exceed $B 3$ degrees $F$ or in any case raise the nomal 1 temperature more than 1.6 degrees F, 15 June through september and not more than 4 degrees F from October through is June. Ail measurenents shall be mode at the boundary of such mixing zones as is found to be reasonable by the Director.

Mone in concentrations or combinations which would be harmful to human, animal or aquatic life or which would make the maters unsafe or unsultable for fish or shellfish or their propagation. impair the palatability of same, or impsir the waters for any other uses.
None In concentrations or combinations which would be harmful to huan, animal or aquatic life or which would me the maters unsafe or unsuitable for fish and shellfish or their propagation. or Impatr the water for any other usage ass 1 gned to this Class.
Nome in concentrations or combinations wich would be harnful to heman, animal or squatic llfe or wich mould make the maters unsafe or unsultable for fish or shellfish or their propagation, or inpoir the mater for any other usage assigned to this Class. The anbient concentration of a pollutant in a water body des I gnated as suitable for fish and/or wildiffe habitat shall not exceed the R.I. DEM Ambient Mater Quality Guldelines (ses Appendix 8) for the protection of aquatic organisms from chronic effects, unless the chronic guideline is andifled by the Director based on results of bloassay tests conducted in eccordance with the tents and conditions provided in Appendix $C$.

If an aquatic toxicity value has not been established in the R.I. DEM Nmblent Hater Quality Guidel ines (see Appendix 8), then the level of any "priority poliutant" (see Appendix B) shall not exceed the "detection 1 inits" in the amblent water unless the discharoer demonstrates to the satisfaction of the Director that a higher concentration will not adversely effect the most sensitive use of the water body.

- Gulde. Dendsng rurther reeeereh 
6.4 Water Quality Standards - All waters of the State have been categorized according to the water use classification of subsection 6.2 based on considerations of public health, recreation, propagation and protection of fish, shellfish, and wildlife, and economic and social development. The waters of the State are classified according to the list of water segments in Appen$\operatorname{dix}$ A.

All small streams tributary to Class $A$ waters shall be Class A. All other small streams where the classification is not indicated shall be Class B. All other fresh waters not classified shall be considered to be Class A until classified. All sea waters not classified shall be considered to be Class SA until classified.

6.41 Applicable Conditions - These water quality standards apply under the most adverse conditions, as determined by the Director according to sound engineer- ing and scientific practices. For fresh water, most adverse conditions shall include a minimum average daily flow for seven consecutive days that can be expected to occur once in ten years. For tidal waters, most adverse conditions shall mean when the most unfavorable hydrographic and pollution conditions occur at the particular point of evaluation.

6.42 Federal Approval - These water quality standards are subject to approval by the administrator pursuant to subsection 303(c)(2) of the Clean Water Act.

6.43 Periodic Review - The Water Quality Standards shall be reviewed periodically and amended as necessary pursuant to Section 18 of these regulations.

6.5 Low Quality Water - Any water whose quality falls below any of the criteria of subsection 6.3 corresponding to its classification as designated in subsection 6.4 shall be considered in violation of its water quality standard and unsatisfactory for the uses indicated for that class, except for any designated uses which the Director determines are not affected by the particular criterion which is violated. Classes D and $E$ shall be used to describe existing conditions, and shall not be considered acceptable goais for classification of any water. Freshwaters falling below any criterion for Class $\mathrm{D}$ shall be considered to be in a nuisance condition. Waters may fail to meet their assigned water quality criteria from time to time due to natural causes, without necessitating the modification of assigned water use classifications.

6.6 Symbolic Representative of Water Quality Standards. - The Director shall issue maps from time to time which indicate assigned water use classification.

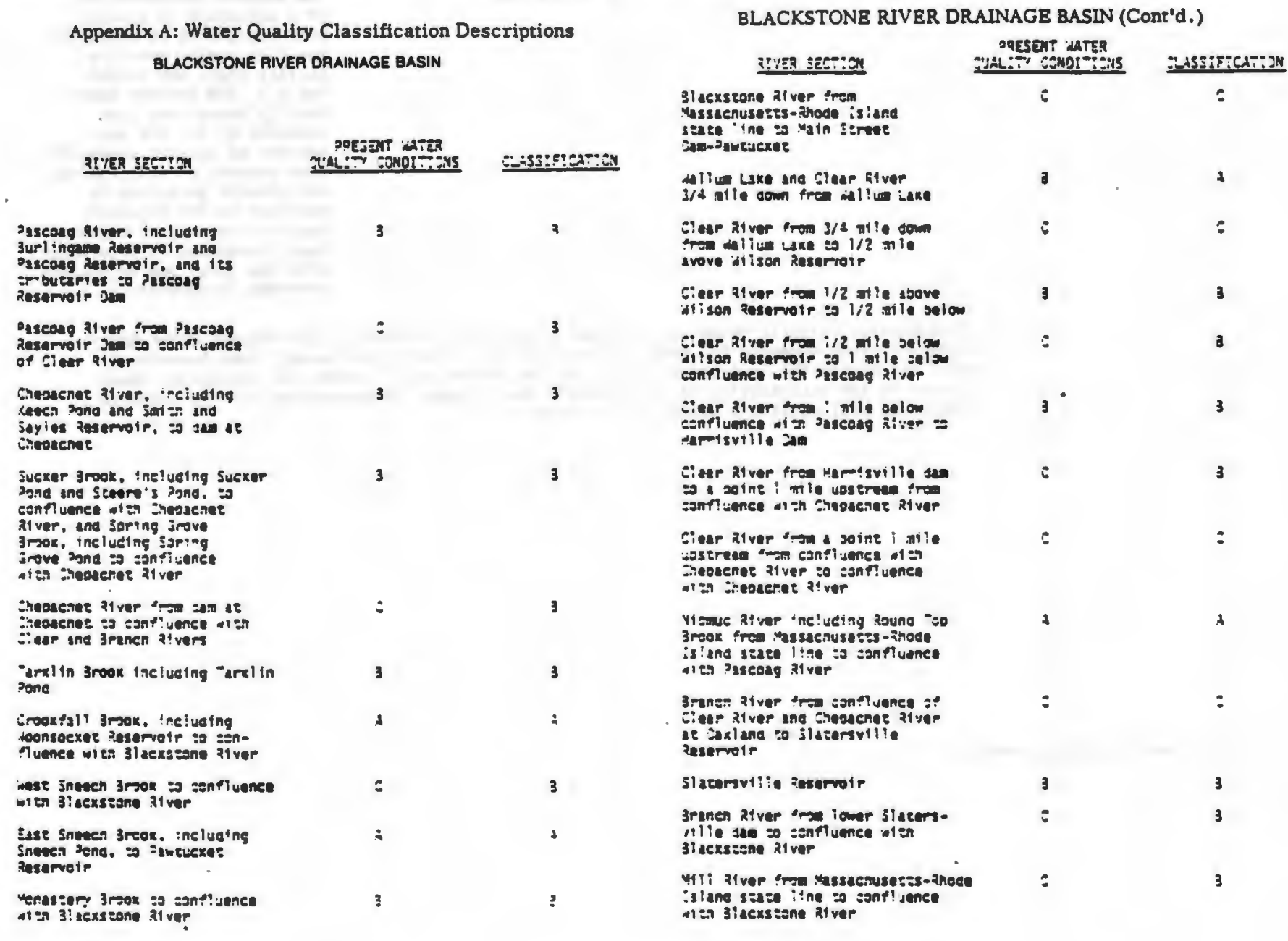


BLACKSTONB RIVER DRAINAGE BASIN (Cont'd.)

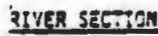

pAEsevi ATER

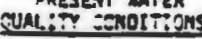

Q⿻-45s:=rencinan

Pators RIver tro vasenemusetsFhoes Island sesen line to

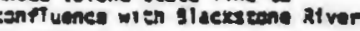

Aboote sun 3rook. incluatng

cotbuearios 0 thed (alant-

vrencruseces seren ito

thoote tan groak fro tessuenusetes-

moces island seren It

$$
\text { c }
$$

3

$\lambda$

$+1$

1

ulen slexsian kt ver

\section{PAWTUXET progs gas: ix}

\section{Irven secton}

Selsue acamotr and all

Trouteries =nerves and Varth

Imenes ?ureunet at ver ine

Set euner Assarvitor so $1 / 2$

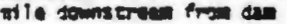

yreh Branes Peweuxere aivar tow $i / 2$ at le towntrean of

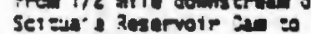
stskevilie 20

botal artuch pawtuxer piver Prow flakeville Jen to the conflucues of woren and south Grancice of ene paweyxut atver It River Patne

Pavaxet 31 ver tron senfluence of voren and souen 3 menches at on Dgine so ene awtuxet Gove In of ? aweuree

Cesnanticut 3 rook es ites sanPuence aith गgweune River

hre sanes 3rook ta 1 es sas-

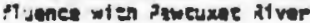

reasset 31 ver and its spieuartes to oune iars inne a1 sestrge

Desssec Alver fro disenarge sp iptine 'bres done so ies eonnluence with Deweuxue afver

\section{Socerele pone}

Masnaowg arook "rom soecencle Pond including tesmague zand

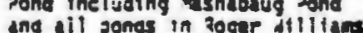
and ail gonds in toger dillian गweuxec शiver

didrien 3rook to is sonfluenee with paweuxet aiver

Itg Rtver tad all lis stby- Prites 20 tes merance inzo Fiat atver zectervip te dertoney ifll daed itgray Srtape

Tat kive Renervatr fou hartsney 4111 bad to South in strex 49 gmany ariogs. danhtng. con on ene south Briven of Prwrixes siver including ail ordangra berteo

South sranen omeunet A1vo fro soues min Street wor. wy artdes. Wasningean te tes

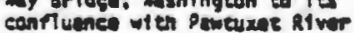
ploge Lak

\section{Jrasene dien}

1

$6 / 2$

e

3
Quiltey conetrteas Gissupteston

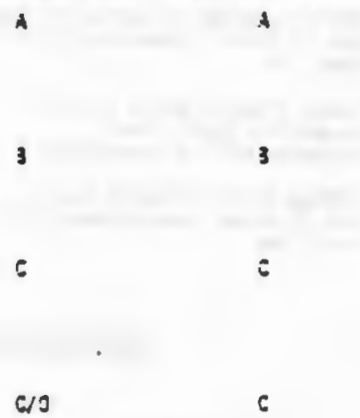

RTVE SET:T:

inten 4om arook 2 souen of Kingeren Road

thite Mom Jrook souch of

Kingsean loed to ter entrance ine sorven pond

Ortruxet River so yangeo mil Pone oan

3roox ertbueary to chtpuxat

Rivor Just aolow rengeo imi

Pond

Antpuxese s1 wap tro rawges

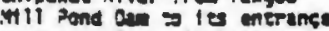

to werten pand, thelueting

tundres ders a ond

Cht exasneen 3rook so Y yoged and

Eriexasnean 3rook iran it

intrunce to vareo sond $=0$ is

senfluence al th jsqueave River

Flgrerville arook and soon srook

os ies canfluenee wi en Cueven River

Gucens for: 3rook a 3/1 antle

selow it eeary it primay

juems sare 3roak iran $3 / 4$ at le

jeiow liceory dtaminy ta con-

Munce it th Juen klver

jueen liver so entmance so bear $\operatorname{sen}$

Huen itver irm entrance :a jear juase so sanpl uenee jp :uenas sore 3 rook

Fuest Aiver Arsa eanflucnee of Jueens ase 3 mok tnelud-

ing Jien zocx keserror $r$ and 'Jssuegaug 31 ver :o =anfluence 'Jssuegaug atver : 0 =?

sscuiset Pond and Pasquiset iroax

Beaver atvar so tes esnflumed wic ? werentuex ither

vadow 3roak es it conflumen it en Parcaeuck atver

indan ceat smato and Brook

Toarting grook so tes confluemes with wood River

dood Aiver Inclueting 3ratkhaer: 3rook, Aeld sacery 3rook, Fice

River. Fall kiver and Perrts

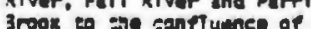

Roaring arook

dood RIver fro confluenee of Rouring groox to das le Wyouring

dood kiver pros dal at dyedín

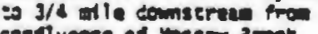
conflunce of wescres $3 \mathrm{mot}$

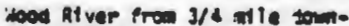
serven ifre contluence of bseo

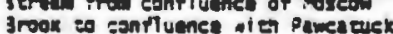

atver

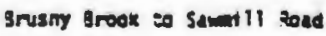

irassy zone and firessy 3rook to

its entranee es dineneets Pand
Juallet Endtefons Eiastfication

$\star$
3

4

$\lambda$

3

2

3

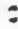

3

A




\section{ATVER SETTIOW}

woseow srook from and ineluding amogo pond. Winertex Pane and

Tuenes wt th wood 31 ver

Conanenet 3rook from and includine denville Pond and slue zane os ies conrluence wien dood Rtver

Poquitene grgek form and including diatenaug vona :0 tes son-

Muence with ane amcatucx

21 ver

i rmaug 3rook =0 les con

fiuence wiga Pawcatuek liver

Enagen pond and Aqureaug 3rook

Isnemay River so Asnaway Roed

nignuy brides

Asneway River from denewar

iosd miemay orifos to sanrluenes

- di ten paventuer at ver

sucasuex atver mo and includ-

Itwedzulk al wep tron sad at senyon to it orit sows craen s? Torsesnoe fallis 20 de

Sinannoet

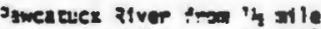
souscren sf torsesnoe Fill sal of Shannest so Caroline sar

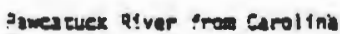

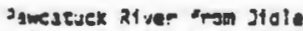
vie :g Weeting touse Irisge

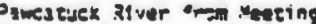

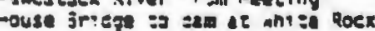

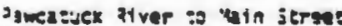

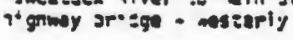

gucatuex River :-gn bin street

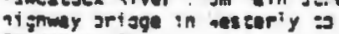

zincaticx toex

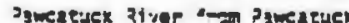

sarne $a$ zhodes jatre

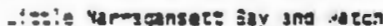

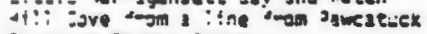

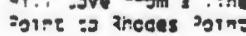

z:sex : ilane jound, mes: gf yaberres

Antene Haen

quits Condetore clastricacton

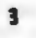

3

a

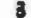

3

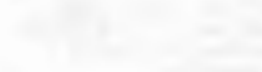

$\star$

\section{- ARHES RIYER MSIM} cocustrille oond to its eoning worean sond to sal it kenyon an to Jidle tol.

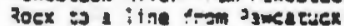

6

\section{RIVER SECTIOA}

PRESEI WATER

qualtr conoltions

gussintation

kaweh Srook, inclidding Peek Pond, to ?hode Is land-Comestsot state if ine

Why Srow Brogk Including Howatis and, Elartrille Pond, Somish

iesarvoir, dllkur Pond, and Lake

wishingeon to Rhoce Is land-

Connerticut state iine

Cady 3root including vowry wedow 3rook to thoes is I and-Connecticut scaes I ine

whesesne trook incluefing $x+11$ ingly ione es anoed island-ionnecsteus seare liat

bosus River to mode island

Eonnectreut staen line

incluaing 11 tes :rtbuearies

'senuug Jrook ine!uding Beaen Pond :o thooe :sland-ionnectest seace in

\section{MOOHASQUATICKET RIVER EASIL}

\section{RIVER SECTIOA}

Stllimater Miver and tes trloutertes, Includiag rim Poot trook ind Materman Resur. votr, to Its entrance lato stllibater heservole

Slact Aeserwetr and the brogk froe slact enservolr to still. water River

Sprague Upper Reservelr and Sprague Lower Meservolr to stlliwater Miver

Muncafadale Meservotr

Woonasquatuctet AIver and Stlll-weer Reservolr

Hoonasquatuektet AIver and Stllinder Pond, Capron Pond ind Georglevtlle Pond

Woonasquatuctet Rf ver fron Georglaville Pond oan to Esmond MIll Orlve

Hoonasqustucket MIver from

Eshund MIll Drlve to Its confluence with the Provldance hi der In Providence

WOSHASSUCX RIVER SASLY
TIVAR 5ET:CN

Crop: Fare aroox to Proct island-wonitectest seare $11 \mathrm{~m}$

31 acemore brook Ineluding fedar Swase Pone ine Hakertele pgne =0 ihsece Is land-Connecticus staed ine pacsem warta

whiti: comortrons :-Assification

s
RIVER SECTIOA ineluding al cachery Pone. cosnessuet RI ver roove on
D

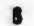

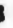

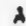

\section{pacsent unten \\ quality conotrios}

-

CLASSIFtCarion

เ

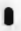

?

.

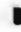

a

6

6
गREsEN MTE qus:in conprtions 
mosmassucx aivea gasi.y (comid.)

\section{AIYER SECTICN}

wohascuet Miver combercen of Jleserery gond eo comfluence with provtdone RI ver at Providentel

4 is afver Ineluding insecots Reservote a $1 / 2$ at le domstrece of inmerel Sorfing Averue

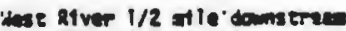

pResEnT wart? quatir canoltrons

c

alssiler:estran

6

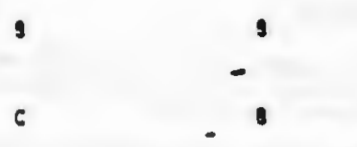

compluence dith thoshassuct RIvar

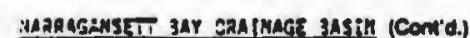

Ind Jmer in duene

orescat water

SEFi:-9

Providene kiver tren Providence seuen aulley eandeton

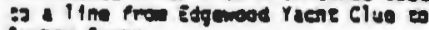
Powe Roexs

รา

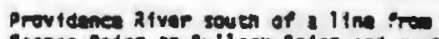
caspes Paine ed sulleex Poine une nore

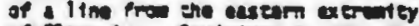
af El ten Ave.. Conicicas to the merane of itussachuck Crent. aurringean

Providenen River seuth of I Im from the enstarn exerent 5 or El ten Ave.. to the

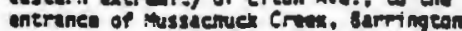
noren ind wat of $11 \mathrm{~m}$ fros contatere asine to contotese Lighe enemen sa did inar ac Mayate paine

Juckey sroek from domstrase and of Samite Jone to Jay

vear shore iress tro Conintere paine to darvite vect: ifhe

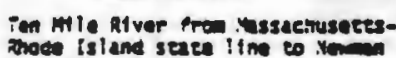
Averue an

Ten mle River from Nomen Averue 2in to centluence with Stakonx

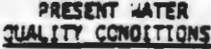

\section{Cissifteatron} River

Seven Mle Atver tron mssenugetesthode Solan staen line so its eanfluence with in inle $21 \mathrm{ver}$

\section{SAUCATLCXE. GIVER JRLLVACE gASTiN}

\section{RIVER SETITOS}

Saugrtucket RI ver ineluding Ingtan lake und Sauquexer Pand es vores Rose. Paee Oule, South $x$ inçsen

Racky Srook theluding Ase Pond. Paces Cale Reservoir ind Bocxy areot acservoir to its sanfluene. wien Sungatexee Alver. Pace Lale. South kinesegm

Indin RuA Jrook Ineluding !ndian afver Reservoir es les sohrtuenes

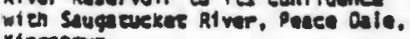
$x$ ingreon

Saugatucket Rlver ire Xingston Rose

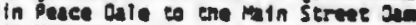
in iekeftold (1.1 atles)

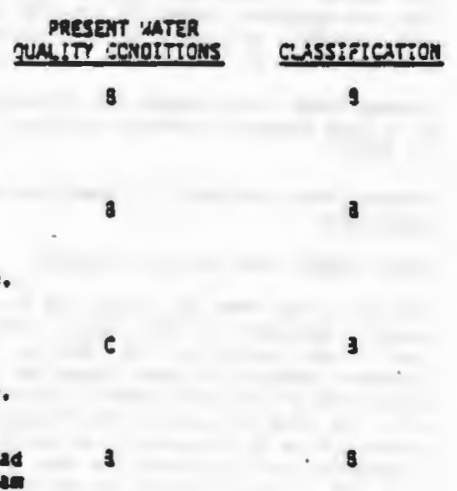

XARRAGANSTT MAY ORAWACE 3ASTX

And oeher se wers

\section{SECTIEN}

9 resent Weer gulley Condtetong
Seokent afver ire Maln Street do,

pureseter, so india polne. providanes

spovidance Rtver south of a IIme tro Edgewood Yeene C? ue to Powine Roeks and nores of a line pres casese poine to lulloet polne
36
S6
Cisrteferean

Se

se

darmen and sarrtageon kivars tre . al State Ifrie is milirace jpreges noren of 2t. 103

Warmen ine sarmingen Q1vars fros ratl roed

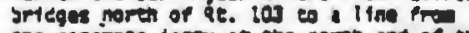
ta conerves tecty it the noren end of ene dam ?om deses enrougn lun suoy :4 in tits exeansion os the 3armingen shore

"iarren River south of 4 itine iron the concrves jetcy it ane north end of the

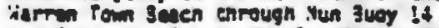
and its oxemston to the garringeen shor and noret of IIne fre darms pathe so vicass Poine

Uoper Yarrogansoes say in se vietnity of Korth Fin on one jay souen op line tro ine northernest extret $7 y$ of the brumen

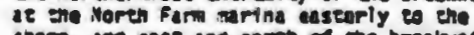
norv. ine case sne noreh of the srentweep as the Neren famm nartina (s ceres)

nount hope bay ease une noreh of I Ines. fothe the pollowing ooines: The of

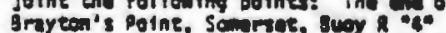
and boreen's thare. Fiveres

moune tope say wose and seuth of Ifies Joining sie following coints: The end of

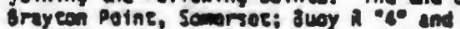
Jorden's dunnel, piverten and cast of Ifnes Jainfng tho foliowing catines: the and of Eartier's rect Rosd, Steonseo;

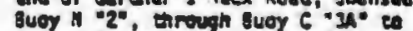

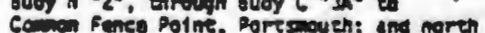
of a line dren prom portsoust ind Tiverten at the stent Irtdgo

Wount Hope say wet unt soven of 1 ines foining te following coines: vien of Aarmer's iech Mout. Junses, Suro

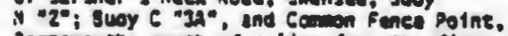

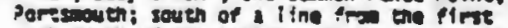
coet nores of the coreranes to the xleteruft

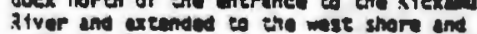
cast of a line prom sngr so snors sassing enrough ent nast weserly soines of she enrough ent nost weterly solnes of the

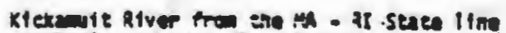
soutrerly to isma lase aridge

kleknuit alyer seutherly org darm kond irtege en child strete ortege

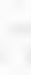

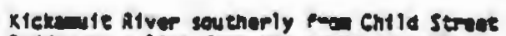

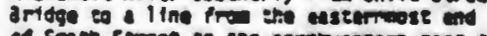
of sor th strect ed ene nortmestarn nose 5 fo of Coqgesnall denninsuic 


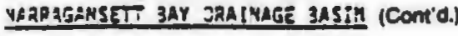

\section{Ine joner in waters}

Present vacer

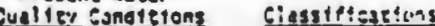

\section{SECPI:Y}

The xtekenite aiver souereriy iran I line

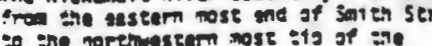

co sne noremastam nost :49 of sele

stafford agne and Suckertirsok to $\mathrm{Rl}$ - Wh

jeare i ine

Sin and Fean 3reok to Fith Street

Sin and flean srook tron flen Straet to

quin Straet (Re. T) Tivarean

danovilll 3roek $=R I$ - M State líne.

Tiveren

Oundery 3roek to Mentinghouse Lane

Suncery 3rook from wertnghouse Lane $=1$

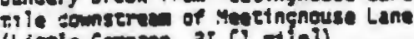

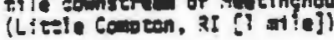

Juncery Jroek prom ! gile comserver of

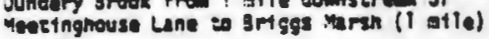

Sakonnot River oft sae cuse smore of

دarsencuth in ena vietnity of Elmurst

teadry

Sakonnat hiver souen and wat of a line tron ine Rhode islune Jeouratent of Heallt renge

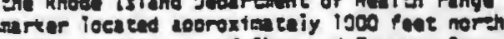
of the esseart and of Shanwood ierrees Rose.

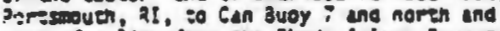

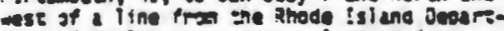
rene of ceal th range rarkor lacated luse

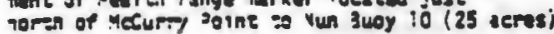

3erstol hargor aesz of 1 i ine trom HeKee's har on 3ristol Yeex $=$ : ignt at Coust juare itenten coes

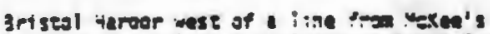
Whare on 3ristal veex as :iggmt it Csast jum

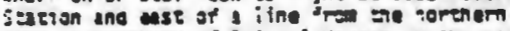

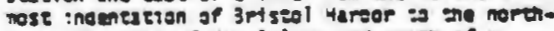
etst ex:Tentsy of voq island ind noreg of a ine ere to norgeise extrenisy of toq island a Mexea's dhare in 3 regeol veer

:aner Aczonaug :sve

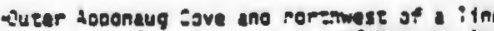
in Cear i pee saine so ena of Yeotune tre. 2n :me asse store

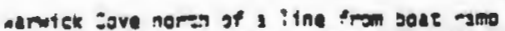
it Seklano jeach to rek asu Jient of absneened -ay! -as srest an ecsi snort

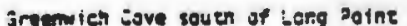

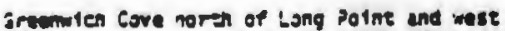
of a line prom ene nerenerly soine of beng point to she souenerly poing of Cheptenaxes ssiand

Pazzer cove at Prudented island

The menrs in tie vicintty of cast ferry west of a line fro Bryar Polnt to a cotst coproximatenly ises feet souen of sampensert dve. (51 cervs)

dest Eassege off jemeream in zie vietnity of dest Ferry, xivet and cast of 1 lime from

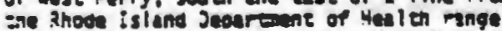
marker locsece at ene warearn and af Watson Avemue of Dureh balend Ligne House and noreh and ast of a line from the sou etrusese esmer

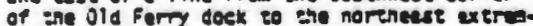
fty of luteh isiane

The weters within 500 :eot of she ilring

Jier of etie U.S. Nevy iorsece iest:ing

seation, sould island

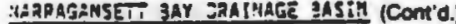

Ine jener in decers

Presane watar

auslity Candtions

Classtefesetoing

The wers in the vicinity of the outfip

in cose outisting factiferes at imold

Iorne, Eise Pussuge

se

56

The wears in the rieintey of the iniced states

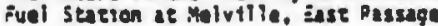

sc

se

The wears in the vieinity of Tayior sothe

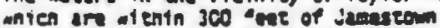

metne outall semer ( 7 eeres)

$x$

si

The weren in the vieinty of Taylor Pothe. exclustve of these wears dencrtbed seove. sough of a in pron the nardhemmose exereats of Teyior paint a can buoy 13, nard of IIme frem goine of land aogmxtmaenty 1000 ecee "south of the Menoor: Serlage to the norynum.

mose extrenty of Rose islane, and within

1000 seet of the snorelina of juneseown

(49 seres)

The weers in ene yiednty of tharean's Inrgyary wich are south and wst of I i ne roren of aull poine eo ene norehermost of

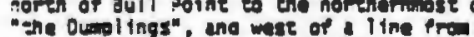
"The Duwolings", and west of a I ine trom oesne of land upprozintedy 1000 fece mores of Buil Poine (17 ceres)

atory in the viefnity of Ease Cove and Fore Hethen 111 wien ar wase of a line from the nomence somer of the oler at Fare dectartll to gethe of land in she norence snore of =

5.

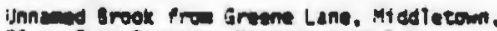
R! te Sase Pessage, Marmoensete Say (i) antie)

Jnneased Arook uaxtren of Greene Lane vo netgutear

Easten Pond, Hadletern and Yeveore

Ease of a line from lda lewis Rock so the soucherm eatretty of soat islane sase of boat island, ase of a line tro the

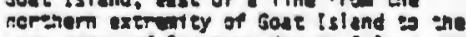
nese snore of Coasears Hertor :sland, ease gr L ino pros ine west snore of Coasears

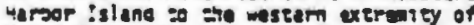
Creotngean Dyine ind south ind ets: of 1

l:ne fro the sourmesente ex--erity of - sodingeon ?aine on soek locateo nor is mavy seatrayer Oier vo. 2, Elase Passage

The are wieny 1000 sect of :-9e west snors

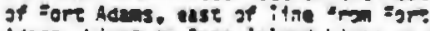

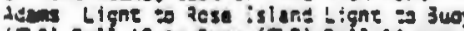

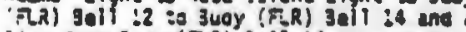

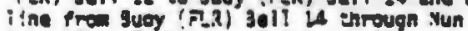
Luoy is at Coddingeon Poine and its exension is ine ase snore of Aoridnect island Ine - $-5=$ of the area in Newoor Hargor are

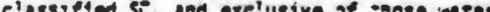
classipled st on are

The waters in the vietatey of For taus.

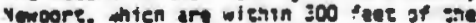
Egrt daies meme outfall sewer it, icres!

The ween in ene vieinfy of :ascen tarsor wies ire within zod ?eet of ene vewoor sarine autill somer (:8 ecres)

The wers in see vicinty of pten ic. I

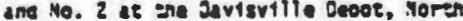
Kingserin

The wears in the vieintey of fuenset Polnt wienin 1500 ince of shore intin sie matern end of ge earrier sier to d doine icod fees nopes of juomec poine 


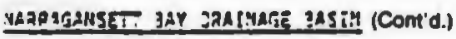

lne yoner ine decers

Trasene decer

scti:日1

The weors th the vietnity of Cuonset Point.

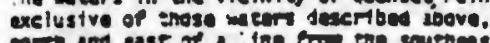

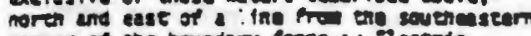
sorners of Ale boundary ines $2: 51$ cotortc Jase 20 Ceneral Reek way, xornt of I Ine

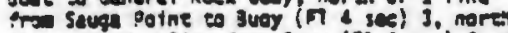
ind we of a IIno tre luoy (FI + sef) 3, to

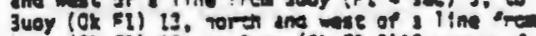
Juey (Gh Fi) 13 , es Juay (CK Fi R) I2, whe af

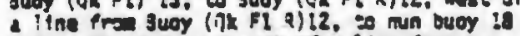

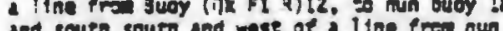
buy is to 201 the sooreximatealy 3000 feet

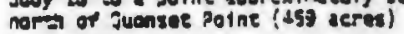

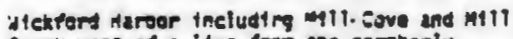
crest wese at i ine pre tene nortereriy enemerty of jig zoex Patne to we weerly exervinty of Carmol "us bsland, wate and

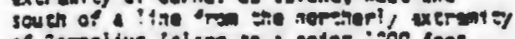
of Eemelifus island os solnt : soc feet mores of alf yecx and ytil breek sou en st t I ine "ro cane dvenue cslvere ind noe thiluating diexpors Save

Acxiart Sove

Fy 3rook soueserly ose jmace ane winsze.

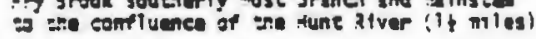

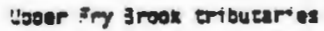

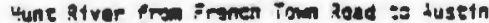
Pad (it it tes)

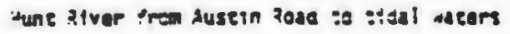

-Ansuquaduckes R!ver, 'ns! ualng 3 elievil?

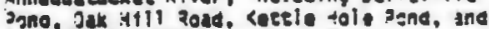
jecrite tike, sa Jasten "Neck taad

3issel Eave wast of che Honestead

Sliverlake. Carp jond and dejothing argok

The weers in se vtetntoy of souch farry

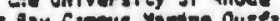
Isiand (9 ieras)

he wiears in the victnty of South forry Rave. Saunderseom, exclusive of hase arer seac-1bea sbove

The wean in the vieintcy of Tucxer's 200

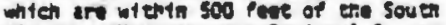
Kingsean/Marmgansets Regtonal Semege irevene plene suefall (fa sc:ve)

The wears in sive vieintey of Pucker's Jock, exclustve of trose wetrs serertbed cove. with ars vitiln 2500 ines or any goine in ene shoriline botwen Conetnental Rosd ind Heare Aveme (207 scres)

APPENDIX B

R.I. DEM AMBIENT WATER QUALITY GUIDELINES PRIORITY POLLUTANTS

I. Purpose. This Appendix contains the ambient water guidelines referenced in Sections 6.32 and 6.33 of the Rhode Island Water Quality Regulations as

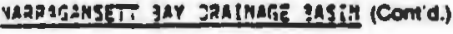

Ind J:her ise duser

Iresene wacer

ivalte and 1 tions

Ciessuflezetuns
5

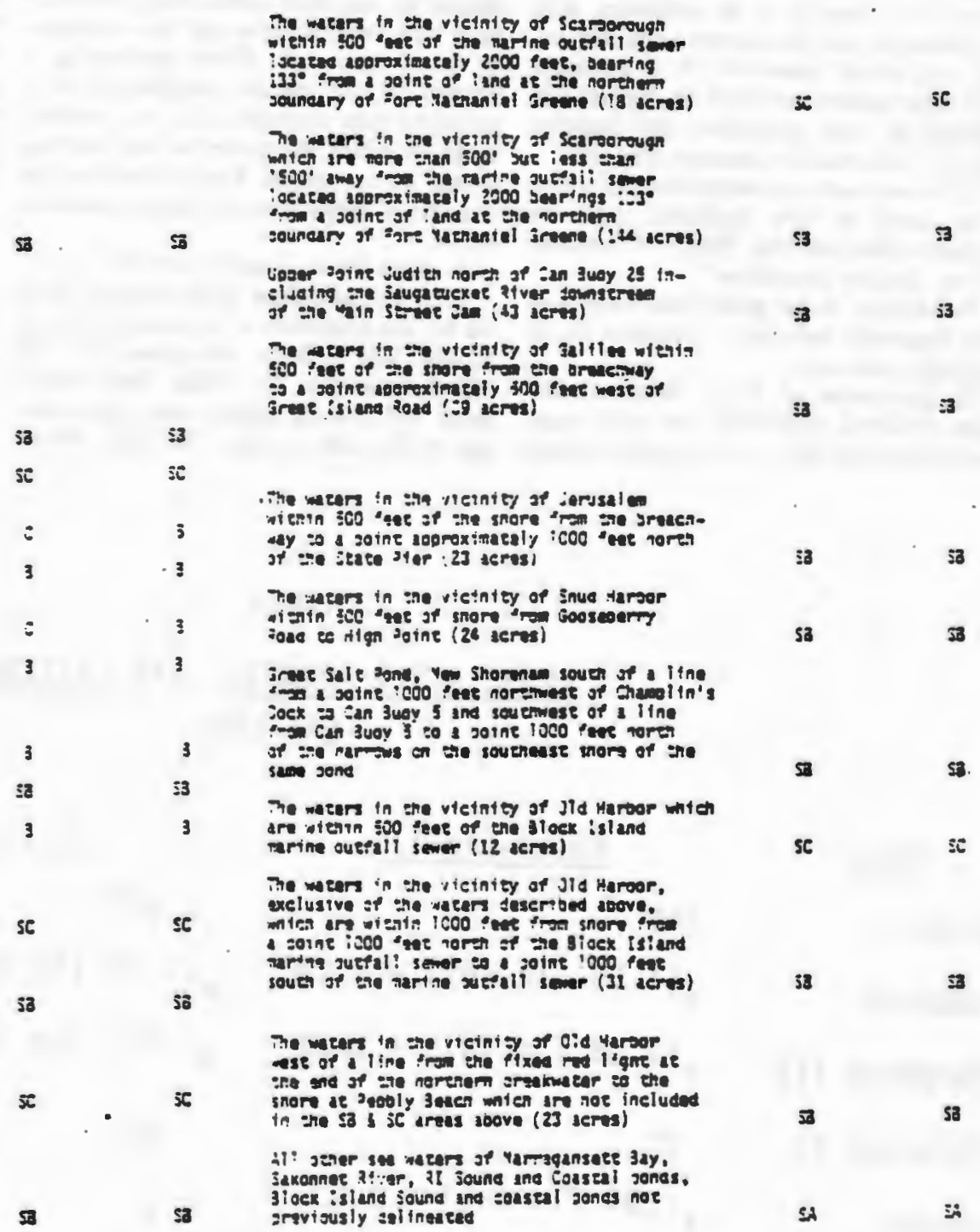

amended. The purpose of these guidelines is to use optimally and consistently all quality data pertaining to the aquatic toxicity of a pollutant in order to determine a concentration of that pollutant which will be protective of aquatic life. These guidelines will be used to assess the quality of any fresh, estuarine, or marine surface water body and to set permit limitations for any facility which discharges into such waters.

All guidelines are subject to site-specific modification procedures referenced in Sections 6.32 and 6.33 of the Regulations and described in Appendix C. In addition, permit limitations may be based on consider- 
ations other than aquatic organism toxicity (see definition of "effluent limita. tion").

This Appendix to the Regulations shall be revised annually or as necessary. Any amendments will be subject to public notice and public comment. It is expected that these guidelines shall be revised and updated as new pollutants are detected and new information becomes available.

All numerical concentrations and equations listed in this Appendix shall be termed collectively the "RIDEM Ambient Water Quality Guidelines".

In addition to the guidelines, table 4 of this Appendix contains a complete list of "priority pollutants".

IL. Derivation of Fresh Water Guidelines. RIDEM guidelines for fresh water can be divided into two categories accord- ing to the methodology by which they were derived. The first set of fresh water guidelines was adopted from the EPA 1980 Water Quality Criteria, while the second set was developed using minimum data base requirements and an uncertainty factor approach. When evaluating a request for site specific modification of a guideline (see Appendix C), the methodology by which the guideline was derived should be considered. For this reason, the two sets of guidelines are listed separately below.

\section{A. EPA Water Quality Criterio}

EPA has published water quality criteria for the protection of aquatic life for 21 of the 126 priority pollutants (45 FR 79318 November 28, 1980). These pollutants are priority metals and pesticides. and PCBs and cyanide. The EPA Water
Quality Criteria consist of both an acute concentration and a chronic concentration for each pollutant. The acute concentration should not be exceeded in the ambient water at any time, while the chronic criterion should not be exceeded by the average concentration of the pollutant over any 30 day period. The methodology by which these EPA criteria were derived is given in the Federal Register announcement.

On 7 February 1984, EPA published in the Federal Register proposed revisions to several of the 1980 water quality criteria (49 FR 4551). With the exception of chromium III for which no 1980 criteria were available, the 1984 fresh water criteria will only be adopted by the State after they have been promulgated by EPA.

\section{TABLE I}

FRESH WATER AQUATIC LIFE CRITERIA

EPA 1980

\begin{tabular}{|c|c|c|c|}
\hline Name & Acute- $(\mu g / 1)$ & Chronic- $(\mu \mathrm{g} / 1)$ & 1984 \\
\hline Arsenic & 440 & $9.8^{(a)}$ & $x$ \\
\hline Cadmium & $e^{(1.05[\ln (H)]-3.73)}$ & $\mathrm{e}^{(1.05[\ln (\mathrm{H})]-8.53)}$ & $x$ \\
\hline Chromium III & $e^{(1.08[\ln (H)]+3.48)}$ & $\mathrm{e}^{(.819[\ln (H)]+.537)^{(b)}}$ & $x$ \\
\hline Chromium VI & 21 & .29 & $x$ \\
\hline Copper & $e^{(.94[\ln (H)]-1.23)}$ & 5.6 & $x$ \\
\hline Lead & $e^{(1.22[\ln (H)]-0.47)}$ & $e^{(2.35[\ln (H)]-9.48)}$ & $x$ \\
\hline Mercury & 4.1 & .2 & $x$ \\
\hline Nickel & $e^{(.76[\ln (H)]+4.02)}$ & $e^{(.76[\ln (H)]+1.06)}$ & \\
\hline $\begin{array}{l}\text { Selenium } \\
\text { (Selenite) }\end{array}$ & 260 & 35 & \\
\hline Silver & $e^{(1.72[\ln (H)]-6.52)}$ & acute/ $45(c)$ & \\
\hline
\end{tabular}


Name

Acute- $(\mu g / 1)$

Chronic- $(\mu g / 1)$

1984

Zine

$e^{(.83[\ln (H)]+1.95)}$

47

\section{Aldrin}

Dieldrin

Chlordane

DOT

Endosulfan

Endrin

Heptachior

gamma-BHC

(Lindane)

Toxaphene

Cyanide

PCBs
3

2.5

.0019

.0043

\section{1}

.0023

.0038

.013

NOTES: All units in $\mu \mathrm{g} / 1$

$\mathrm{H}=$ hardness $\left(\mathrm{mg} / \mathrm{l}\right.$ as $\mathrm{CaCO}_{3}$ )

(a) No EPA chronic criterion is available for arsenic. The value given was obtained by dividing the acute value by an scute to chronic ratio of 45 . (b) No 1980 EPA chronic criterion is available for Chromium III. The equation given is proposed by EPA but not yet promulgated.
3.5

.014 $x$ (c) No EPA chronic criterion is available for silver. The chronic value should be determined by dividing the acute value given by the hardness equation by an acute to chronic ratio of 45 . 
B. Minimum Data Base Guidelines

RIDEM has derived freshwater guidelines for many pollutants for which EPA Water Quality Criteria are not available. In order for a guideline to be derived, the toxicity data base for the pollutant must meet minimum requirements.

The data base must contain at least two acute toxicity test results expressed as either an $\mathrm{EC}_{90}$ or an $\mathrm{LC}_{90}$ as specified in the EPA Water Quality Criteria Guidelines (45 FR 79343, 1980). " $L C_{30}$ " is defined as the concentration of a test material in a suitable diluent at which 50 percent of the exposed organisms die during a specified time period. "EC ${ }_{s 0}$ " is defined as the concentration of a test material in a suitable diluent at which 50 percent of the exposed organisms exhibit a specified response during a specified time period.
The two acute toxicity test results shall tor was selected by calculating uncertainty consist of:

1. One daphnid (D. magna or D. pulex) 2. One fish, either:

(a) fathead minnow (Pimephales promelas)

(b) bluegill (Lepomis macrochirus)

(c) rainbow trout (Salmo gairdneri)

For every pollutant which meets these minimum data requirements, acute and chronic guidelines are derived using the following equations:

Lowest LC $_{*}$ or $\mathrm{EC}_{\infty} \times .05=$ Acute guideline

Acute guideline $\div 45=$ Chronic guideline

The uncertainty factor, .05, is intended to provide an adequate margin of safety to protect most aquatic organisms from acutely toxic effects. The uncertainty fac- factor guidelines for those pollutants with EPA Water Quality Criteria. These guidelines were most similar to the EPA Water Quality Criteria when an uncertainty factor of .05 was used.

The acute guideline is divided by an acute to chronic ratio of 45 to yield the chronic guideline. This ratio was derived by the State of Michigan using all available acute to chronic values for priority pollutant tests performed on fresh water species. It was determined that $80 \%$ of the pollutants would have a geometric mean acute to chronic ratio of 45 or less.

The methodology by which these criteria are derived is similar to that used in the EPA Red Book (1976) which preceded the 1980 Water Quality Criteria.

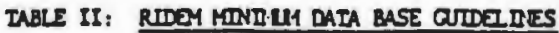

\begin{tabular}{|c|c|c|}
\hline $\mathrm{Nem}$ & Naven (yg/1) & Grande (1/ $/ 12)$ \\
\hline Acroletn & 2.9 & .06 \\
\hline Aexylanterle & 378 & 8.4 \\
\hline Ancimany & 450 & 10 \\
\hline Argenle III (Inorganie) & 32 & 1.2 \\
\hline Benzene & 265 & 3.9 \\
\hline Baryllum & 7.5 & .17 \\
\hline Crrbon cerrachloride & 2363 & 30 \\
\hline \multicolumn{3}{|l|}{ talortrated benzenes } \\
\hline Cllorobenzere & 795 & 18 \\
\hline 1,2,4-terchlorebervente & 73 & 1.7 \\
\hline 1,2,3,5-Eecrachloroberzenten & 321 & 7.1 \\
\hline pentachlorobenzene & $\mathcal{H}$ & .28 \\
\hline \multicolumn{3}{|l|}{ talortreced ecthanes } \\
\hline 1,1,2-Erachlorouthenese & 900 & 20 \\
\hline 1,1,2,2-tereactlorosethen & 466 & 10 \\
\hline 1.2-dichloronethon & 3900 & 231 \\
\hline 1,1,1,2-tetrachlorouthen & 980 & 22 \\
\hline pentediloroethen & 362 & 8.0 \\
\hline herachlorosething & 49 & 1.1 \\
\hline \multicolumn{3}{|l|}{ Allorlsuced rephtualenes } \\
\hline 1-etloronepheralen & 80 & 1.8 \\
\hline \multicolumn{3}{|l|}{ tolortrated pherols } \\
\hline 2-chlorophereol & 129 & 2.9 \\
\hline 4-chlorophenol & 192 & 4.3 \\
\hline
\end{tabular}

\begin{tabular}{|c|}
\hline Nan \\
\hline 2,4-d1chloropherol \\
\hline 2,4,5-talchlorophnanl \\
\hline 2,4,6-ertchloropherol \\
\hline $2,3,4,6$ - tetrachlorophenol \\
\hline 2,3,5,6-cecrachlorogherol \\
\hline peneachlorophenol \\
\hline 4-chloso-2-anchylphenol \\
\hline 2,4-dichloro-6-0achylpherol \\
\hline Chlarefore \\
\hline Dichlorobenzenes \\
\hline 1,2-dichloroberem \\
\hline 1,3-dichloroberzense \\
\hline 1,4-dichlorobenzenen \\
\hline WHchlorouchylenes \\
\hline 1.1-dlethlorosthylen \\
\hline tDichlorcpropenes \\
\hline 1,1-dichloropropme \\
\hline 1,2-diehloropropmen \\
\hline 1.3-dichloropropen \\
\hline 2,4-dimechylphenol \\
\hline Dinderocolunas \\
\hline 2,3-dirleneolume \\
\hline 2,4-dinferotolume \\
\hline Dephery lbydrarine \\
\hline
\end{tabular}

Acute

Nate (4V/1) Corante (ue/1)

101

2.2

21

.91

16

7

๑.5

.36

.16

$2.2 \quad .05$

.19

1

22

.32

.48

1409

32

$\begin{array}{rr}79 & 1.8 \\ 390 & 8.7 \\ 56 & 1.2\end{array}$

580

13

$\begin{array}{cc}1150 & 26 \\ 2625 & 58 \\ 303 & 6.7 \\ 106 & 2.4\end{array}$

17

.37

1550

34

14

.31 
IABLE II $(\operatorname{can} ' t)$

\begin{tabular}{|c|c|c|c|c|c|}
\hline & & & \multirow{2}{*}{ Nane } & \multirow{2}{*}{ Acues $(0 x / 1)$} & \multirow{2}{*}{ Quenic (us/1) } \\
\hline$\therefore \quad \mathrm{Nan}$ & Aaven $(4 x / 1)$ & Qheante (Us/1) & & & \\
\hline Eutyl benzena & 1600 & 36 & $\operatorname{mm}=\mathbf{l}$. & $2 s 1$ & 3.6 \\
\hline Malonthers & & & thehaluce estars & & \\
\hline Wbrowophergl phand ether & 18 & .4 & Dimechyl phenalaen & L650 & 37 \\
\hline Helomentres & & & OLethyl phchalace & 2605 & 58 \\
\hline Muthylene chloride & 9650 & 214 & Buefl bersyl phochalace & 85 & 1.9 \\
\hline Eremofore & 1465 & 33 & Il (2-ectryl hexyl) phehalace & 555 & 12 \\
\hline Hexachlorocyelopencadtene & .35 & .008 & polynuclerr manede hytrocarbans & & \\
\hline Isophorane & s8so & 20 & Aceruphthere & 85 & 1.9 \\
\hline Muphehalene & 115 & 2.6 & Flusemchene & 199 & 4.4 \\
\hline NLFobarzene & 1350 & 30 & Tecractloroectylen & 260 & 3.3 \\
\hline WLEophenols & & & Thellum & 46 & 1.0 \\
\hline 4nenterophenol & 414 & 9.2 & Toluenes & 639 & 14 \\
\hline 2.4-dinlerophenol & 31 & .69 & Mtchlorouchylere & 1950 & 43 \\
\hline $2,4,6$-rinilcophenol & 4235 & 94 & & & \\
\hline 2.4-dinlero-6-anchyl phanol & 12 & .26 & & & \\
\hline \multicolumn{6}{|l|}{ *16rosminas } \\
\hline N-nicrosodipheny Ladra & 293 & 6.5 & NOE: : denoces cherdeal grap & & \\
\hline
\end{tabular}

III. Derivation of Estuarine and Marine Water Guidelines. EPA 1980 Ambient Water Quality Criteria for estuarine and marine waters shall be adopted as State water quality guidelines for those pollu- time. no minimum data base guidelines for tants for which they were derived. These priority pollutants in marine waters have guidelines are given in Table III. At this been derived.

\section{TABLE III}

\section{SALTWATER AQUATIC LIFE CRITERIA}

EPA 1980

Name

Arsenic III*

Cadmium

Chromium VI

Copper

Lead*
Acute $(\mu g / 1)$

120

59

1260

23

220
Amendment

Proposed

Chronic $(\mu g / 7)$

63

4.5

$x$

18

$x$

4.0

$x$

1984

tabes II (can's) 
TABLE III (Cont'd.)

Name

Mercury

Nickel

Selenium

(Selenite)

Silver

Zinc

Aldrin

Dieldrin

Chlordane

DDT

Endosuifan

Endrin

Heptachior

gamma-BHC (Lindane)

Toxaphene

\section{Cyanide*}

PCBS
1.3

.71

.09

.13

.034

.037

.053

.16

.070
$-3.7$

140

410

2.3

170

Chronic $(u g / 7)$

$.1 \mathrm{C}$

7.1

54

Amendment

Proposed

1984

\section{$\mathbf{x}$}

58
.0019

.0040

.0010

.0087

.0023

.0036

.57

.030

NOTE: * denotes pollutant for which no EPA Water Quality Criteria were derived. The values given are the EPA 1984 proposed criteria.

IV. Detection Limits. If the State guideline for any pollutant is lower than the "detection limit" for that pollutant, the detection.limit shall be considered to be the guideline.
V. Priority Pollutants Without Guidelines. Any pollutant listed on the most recent EPA priority pollutant list published in accordance with Section $307(a)(1)$ of the Clean Water Act (Table
4 of this Appendix) for which there is no RIDEM Ambient Water Quality Guideline shall be regulated in accordance with Sections 6.32 and 6.33 of the Regulations. 


\section{TABLE IV. PRIORITY POLLUTANT LIST}

066 1,1 Dichloroethane

068 1,1 Dichloroethylene

079 1,1,1 Trichloroethane

080 1,1,2 Trichloroethane

075 1,1,2,2 Tetrachloroethane

114 1,2 Dichlorobenzene

067 1,2 Dichloroethane

069 1,2 Dichloropropane

124 1,2 Diphenylhydrazine

078 1.2 Trans-Dichloroethylene

140 1,2,4. Trichlorobenzene

115 1,3 Dichorobenzene

070 1,3 Dichloropropylene

1161,4 Dichlorobenzene

1102 Chloronaphthalene

0842 Chlorophenol

089 Nitrophenol

052 2,3,7,8 Tetrachlorodibenzo P Dioxin

085 2,4 Dichlorophenol

086 2,4 Dimethylphenol

088 2,4 Dinitro-phenol

121 2,4 Dinitrotoluene

094 2,4,6 Trichlorophenol

122 2,6 Dinitrotoluene

062 2-Chloroethylvinyl Ether

117 3.3 Dichlorobenzidine

101 3,4 Benzofuoranthene

1084 Bromophenyl Phenyl Ether

1114 Chlorophenyl Phenyl Ether

0904 Nitrophenol

$1494,4^{\circ}$ DDD

$1484,4^{\prime}$ DDE

$1474,4^{\circ}$ DDT

087 4,6 Dinitro-O-Cresol

095 Acenaphthene

096 Acenaphtylene

053 Acrolein

054 Acrylonitrile

141 Aldrin

142 Alpha-BHC

151 Alpha-Endosulfan

097 Anthracene

037 Antimony, Total
038 Arsenic, Total

055 Benzene

098 Benzidine

099 Benzo (a) Anthracene

100 Benzo (a) Pyrene

102 Benzo (ghi) Perylene

103 Benzo (k) Fluoranthene

039 Beryllium, Total

143 Beta-EHC

152 Beta-Endosulfan

104 Bis (2 Chloroethoxy) Methane

105 Bis (2 Chloroethyl) Ether

106 Bis (2 Chloroisopropyl) Ether

107 Bis (2 Ethylhexyl) Phthalate

056 Bis (Chloromethyl) Ether

057 Bromoform

109 Butyl Benzyl Phthalate

040 Cadmium, Total

058 Carbon Tetrachloride

146 Chlordane

059 Chlorobenzene

060 Chlorodibromomethane

061 Chloroethane

063 Chloroform

173 Chromium +6 Hexavalent

041 Chromium, Total

112 Chrysene

042 Copper, Total

OSO Cyanide, Total

145 Delta-BHC

120 Di-N-Butyl Phthalate

123 Di-N-Octyl Phthalate

113 Dibenzo $(a, h)$ Anthracene

064 Dichlorobromomethane

065 Dichlorodifiuoromethane

150 Dieldrin

118 Diethyl Phthalate

119 Dimethyl Phthalate

153 Endosulfan Sulfate

154 Endrin

155 Endrin Aldehyde

071 Ethylbenzene

125 Fluoranthene
126 Fluorene

144 Gamma-EHC

156 Heptachlor

157 Heptachlor Epoxide

127 Hexachlorobenzene

128 Hexachlorobutadiene

129 Hexachlorocyclopentadiene

130 Hexachloroethane

131 Indeno (1,2,3 cd) Pyrene

132 Isophorone

043 Lead, Total

044 Mercury, Total

072 Methyl Bromide

073 Methyl Chloride

074 Methylene Chloride

136 N-Nitrosodi-N-Propylamine

135 N-Nitrosodimethylamine

137 N-Nitrosodiphenylamine

133 Naphthalene

045 Nickel, Total

134 Nitrobenzene

091 P.Chloro-M-Cresol

164 PCB-1016

160 PCB-1221

161 PCB-1232

158 PCB-1242

162 PCB- 1248

159 PCB-1254

163 PCB-1260

092 Pentachlorophenol

138 Phenanthrene

093 Phenol

051 Phenols, Total

139 Pyrene

044 Selenium, Total

047 Silver, Total

076 TetrachJoroethylene

048 Thallium, Total

077 Toluene

165 Toxaphene

081 Trichloroethylene

082 Trichlorofluoromethane

083 Vinyl Chloride

049 Zinc, Total

\section{APPENDIX C}

Bioassay Protocol and Site Specific Modification of State Guidelines

I. Purpose. This appendix contains a protocol for performing bioassays on industrial and municipal effiuents, and guidelines for using bioassay results to modify state guidelines for a given discharger. The purpose of this procedure is to identify cases where the state guidelines are either too lenient or too stringent due to the specific composition of the effluent and/or the receiving water. Neither negative nor positive bioassay results shall warrant modification of the guideline automatically; but rather the merit of each potential case for modification shall be evaluated individually. In addition, permit limitations may be based on consider- ations other than aquatic organism toxicity (see definition of "effluent limitation").

II. Bioassay Protocol. Industrial and municipal dischargers may be required to perform bioassays in accordance with permit requirements or a request for additional information made by the Director in accordance with Section 46-12-18 of the R.1. Water Pollution Control Law. 
The Director may require a variety of biomonitoring tests including: screening and range finding tests, and tests for acute and chronic toxicity. Unless stated otherwise by the Director, the effluent shall be tested initially for acute toxicity according to the following protocol:

a. Dischargers or their consultants shall test a representative composite sample of their effluent for acute toxicity.

b. Facilities which discharge into fresh waters shall perform the test on both water fleas (Daphnia manga or Daphnia pulex) and fathead minnows (Pimephales promelas).

Facilities which discharge to marine or estuarine waters shall perform the test on mysid shrimp (Mysidopsis bahia) and either sheepshead minnow (Cyprinodon variegatus) or Atlantic silverside (Menidia menidia).

c. The duration of the test shall be 48 hours for daphnia and 96 hours for fathead minnow, mysid, and Atlantic silverside and sheepshead minnow.

d. The test may be static unless loss of DO due to high BOD or loss of potentially toxic volatile pollutants warrants use of a replacement or flow-through test procedure.

C. For single discharge situations, the effluent shall be diluted with receiving water collected immediately upstream of the effluent's zone of influence. For multiple discharge situations where the upstream water may contribute significantly to the toxicity of the effluent, the diluent shall be a designated raw water source unless indicated otherwise by the Director. Future tests may require use of upstream water and/or both upstream water and raw water as the diluent at the discretion of the Director on a case-by-case basis.

f. A portion of each effluent sample used for the toxicity testing will be chemically analyzed. DEM will advise the permittee of all pollutants requiring analysis after considering all contaminants listed in the application, anticipated to be present, or under consideration for limitation in a permit.

In addition, the Department may require chemical analysis of the dilution water if it is suspected to contain significant levels of pollutants.

g. Acute bioassay tests shall be conducted in accordance with protocols listed in the latest edition of Standard Methods for the Examination of Water and Waste- water (APHA), or the latest edition of Methods for Measuring the Acute Toxicity of Effiuents to Aquaric Organisms (EPA), or additional methods if approved by the Director.

$h$. The report of test results shall include a No Observed Acute Effect Level (NOAEL) which is defined as the highest concentration of the effluent (in percent effluent) in which $90 \%$ or more of the test animals survive, and an $\mathrm{LC}_{\boldsymbol{x}_{0}}$ which is defined as the concentration of the effluent which is lethal to $50 \%$ of the exposed organisms.

If selecting a consultant, the discharger should consider:

a. The commitment of management and staff to an effective quality assurance program.

b. Staff experience and education.

c. Adequate laboratory space and equipment to conduct testing.

d. Data handling, record keeping. review, interpretation and reporting.

e. Written test protocols and quality control practices.

III. Modification of Guidelines Based on Bionssay Results

In accordance with Section 6.32 and 6.33 of the regulations as amended, the RIDEM guidelines may be modified based on the results of bioassays in order to better represent site-specific conditions.

A. Modification of state guidelines may be warranted in either of two generalized cases:

1. If a discharger is in compliance with state ambient water quality guidelines given in Appendix B, yet bioassay test results demonstrate that the effluent is likely to cause toxic conditions in the receiving water. then the state guidelines shall not be considered protective for the given site and discharge.

Bioassay results shall be interpreted in the following manner to determine if toxic conditions are likely to occur in the receiving water:

Equation 1:

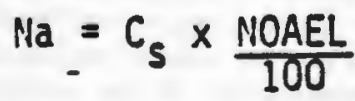

Equation 2:

$$
H C=\frac{N a}{A C R}
$$

Where:

NOAEL $=$ No Observed Acute Effect Level, determined by toxicity tests and defined as the highest concentration of the effluent (in percent effiuent) in which $90 \%$ or more of the test animals survive.

$\mathrm{C}_{s}=$ the concentration of the pollutant in the effluent sample before dilution (ug/1)

$\mathrm{Na}=$ the non-acutely toxic concentration of the pollutant (ug/1)

$\mathrm{Nc}=$ the non-chronically toxic concentration of the pollutant (ug/1)

$A C R=$ acute to chronic ratio established for each pollutant using EPA water quality criteria documents or other more appropriate data. A default value of 45 shall be used if no reliable information is available.

For wa'ers classified as B, C or SC, if $\mathrm{Nc}$ is less than RIDEM guideline, then the guideline may not be protective of water quality and modification may be warranted.

If the determination of significant positive bioassay results is made, the discharger must follow one of two procedures:

a. For uses which protect aquatic life and habitat, the concentration of each pollutant in the effluent shall not exceed the concentration which results in attainment of the non-chronicially toxic level in the receiving water.

-Freshwater:

Using Nc from equation 2, the following equation shall be used to determine the appropriate concentration in the effiuent for each pollutant that was detected during the test:

Equation 3: $C_{E}=N c\left(Q_{u}+Q_{E}\right)$

$\mathrm{QE}_{\mathrm{E}}$

Where:

$\mathrm{C}_{\mathrm{E}}=$ concentration in the effluent which will result in non-chronically toxic conditions in the receiving water under low flow conditions (ug/l)

$Q_{u}=$ ten year, seven day low flow for the receiving water (MGD)

$\mathrm{QE}=$ flow of the effluent (MGD)

-Saltwater:

The non-chronically toxic effluent concentration for each pollutant in the effluent sample shall be calculated by multiplying Nc. from equation 2 with the appropriate dilution factor. The dilution factor shall be calculated for both near field and far field using equations in Sec- 
tion 17.12(b)(ii) of the RIPDES regulations, or other methods which are found to be acceptable.

b. The discharger shall conduct a Toxicity Reduction Evaluation. This evaluation shall include:

1. isolation of the sources of effiuent toxicity.

2. determination of the specific causative pollutants if possible.

3. determination of the effectiveness of pollution control options in reducing the effluent toxicity.

4. demonstration of reduced toxicity using bioassays after the control option is installed.

Permits based on the results of the Toxicity Reduction Evaluation shall consist of

- limitations of specific toxic pollutants and/or limitations of pollutants which are proven to be indicators of toxicity.
2. If any discharger is discharging or proposes to discharge an effluent which is predicted to result in a violation of a RIDEM Ambient Water Quality Guideline for one or more pollutants in the receiving water after low flow dilution, the discharger may petition the Director to modify the guideline or guidelines for the specific location and effluent based on significant negative bioassay results. If the results are determined to be significant by the Director, the site-specific protective effluent concentration $\left(C_{E}\right.$ will be determined using equations 1 and 2, and either equation 3 or the marine water dilution equations in Section 17.12(b)(ii) of the RIPDES regulations.

B. The Director's evaluation of the significance of negative or positive bioassay results shall include:
1. the frequency and consistency of test results

2. the test protocol including:

a. number of species tested

b. survivability of the control group

c. test method (static, replacement, flow-through)

d. quality assurance and quality control used by the laboratory:

3. representatives of the effiuent sample used in the bioassay; complexity and variability of the effluent.

4. similarity of dilution water used in the test to the the anticipated composition of the receiving water under worst case conditions.

5. relative certainty of the acute to chronic ratio used in bioassay interpretation.

6. relative certainty of the RIDEM Ambient Water Quality Guideline. 


\title{
RHODE ISLAND DISCHARGE FEE SYSTEM REGULATIONS
}

\author{
(Rhode Island Department of Environmental Management, Division of Water \\ Resources, Rules and Regulations Pertaining to a User Fee System for Point Source \\ Discharges that Discharge Pollutants into the Waters of the State; Adopted January 5, \\ 1984)
}

1.00 Purpose. The purpose of these reg. ulations is to establish a user fee system for point source dischargers that discharge pollutants into the surface waters of the State. The funds from such fees are to be used by the Department of Environmental Management to develop and operate a pollution monitoring system and to protect. preserve and upgrade the surface waters into which the discharges flow.

2.00 Authority. These regulations are adopted pursuant to Chapters 46-12-4, 42 . 17.1 and $42-35$ of the General Laws of Rhode Island as amended.

3.00 Definitions. The following terms shall, unless otherwise specified, be construed in harmony with and shall supplement those terms contained in the Rules and Regulations promulgated pursuant to the National Permit Discharge Elimination System (NPDES) and/or the State administered program thereunder (found in Rhode Island General Law, Chapter 46-12).

"Annual User Fee Assessment Date" means the date designated each year by the Director on which the Department mails to each point source discharger an assessment of its annual user fee.

"Biological Monitoring Method" means a testing method which utilizes any biological system (or any of its parts) for assessing the presence or effects of one or more pollutants and/or environmental factors, either alone or in combination. 'Biomonitoring" refers to acute toxic bioassays.

"Clean Water Act" means the Federal law enacted under 33 U.S.C. \$1251 et seq. and any amendments thereto.

"Conventional Pollutants" shall be determined by applying the following tests:
BOD, Total Suspended Solids, pH, Settleable Solids and Fecal Coliform Bacteria.

"Department" means the Rhode Island Department of Environmental Management (DEM).

"Director" means the director of the Department of Environmental Management or any subordinate or subordinates to whom he has delegated the powers and duties vested in him by these regulations.

"Discharge" means the addition of any pollutant to the waters from any point source.

"Discharger" means any person, corporation, municipality, sewerage authority or other legal entity, that discharges. causes a discharge, permits a discharge, or who fails to exercise reasonable care to prevent a discharge.

"Effluent Limitation" means any restriction imposed by the Director on quantities, discharge rates or concentrations of pollutants which are discharged from point sources into waters of Rhode Island, the United States, the contiguous zone or the ocean.

"EPA" means the United States Environmental Protection Agency.

"Facility" means any point source orany other activity (including land or appurtenances thereto) that is subject to regulation under the NPDES permit program.

"Fee Assessment Document" means a report, prepared at least annually by the Director, containing an analysis of the cost of the pollution monitoring program and an assessment of the annual user fees.

"Major Facility" means any facility or activity classified as such by the Director in so far as it applies to the assessment of fees, and shall not in any way limit the definition of "major facility" as defined by the Regional Administrator of EPA for the purposes of the NPDES Program. Facilities that are deemed to have significant flow and/or environmental impact, as determined from time to time by the Director. shall be classified as major facilities and tested in accordance with established sampling requirements. (A listing of present major facilities is attached as Appendix A).

"Metal Priority Pollutants" are: Antimony, Arsenic. Beryllium, Cadmium, Chromium, Copper, Lead, Mercury, Nickel, Selenium, Silver, Thallium and Zinc; Additional: Asbestos, Total Cyanide and Total Phenols.

"MGD" means millions gallons per day. "Minor Facility" means any facility or activity not classified a "major facility" by the Director of the Department.

"Monitoring" means any method estailished by the Director for identifying and assessing pollutants that are discharged from point sources into surface waters of the State.

"Monitoring Report Forms" means those forms utilized by DEM or EPA, including any subsequent additions, revisions or modification thereto.

"Municipality" means a city, town, borough, county, parish, district, quasi-government corporation, association or other public body created by or under State law and having jurisdiction over disposal of sewage, industrial wastes, or other wastes, or an Indian Tribe or an authorized Indian Tribal organization, or a designated and approved management agency under Section 208 of the Clean Water Act.

"National Pollutant Discharge Elimination System (NPDES)" means the nation- 
al program for issuing, modifying, revoking and reissuing, terminating, monitoring and enforcing permits, and imposing and enforcing pretreatment requirements, under Section 307, 402, 318, and 405 of the Clean Water Act. The term includes any State program which has been approved by the Regional Administrator.

"Organic Priority Pollutants" shall be defined as all those designated as priority pollutants by EPA, except metals, total phenol and total cyanide (for listing see Appendix B).

"Person" means an individual, trust, firm, joint stock company, corporation (including a quasi-governmental corporation) partnership, association, syndicate, municipality, municipal or state agency, first district, club, non-profit agency or any subdivision, commission, department, bureau, agency or department of state or federal government (including quasi-governmental corporation) or. of any interstate body.

"Point Source" means any discernible, confined, and discrete conveyance, including but not limited to any pipe, ditch. channel, tunnel, conduit, well, discrete fissure, container, rolling stock, concentrated animal feeding operation, or vessel, or other floating craft, from which pollutants are or may be discharged. This term does not include return flows from irrigated agriculture.

"Pollution" means any dredged spoil, solid waste, incinerator residue, filter backwash, sewage, garbage, sewage sludge, munitions, chemical wastes, biological materials, radioactive materials, heat, wrecked or discarded equipment, rock, sand, cellar dirt and industrial, municipal or agricultural waste discharged into water.

"Pollutant Monitoring Program" means all those actions, undertaken by the Department, including the procurement of all necessary equipment and personnel, to (a) develop, operate, maintain and enforce a means of monitoring the discharge of pollutants into the surface waters of the State from point source discharges; (b) assess the overall impact from such discharges; and. (c) protect, preserve and upgrade the surface waters into which such discharges flow.

"Priority Pollutants" means those pollutants specified pursuant to Section 307(a)(1) of the Clean Water Act.

"Publicly Owned Treatment Works
(POTW)" means any facility for the treatment of pollutants which is owned by the state or any political subdivision thereto, municipality, or other public entity, including a quasi-government corporation. This term shall also include sewers, pipes which convey wastewater to a POTW, as well as any equipment, buildings or machinery used in the treatment operation.

"Regional Administrator" means the Regional Administrator of the appropriate Regional Office of the Environmental Protection Agency or an authorized representative of the Regional Administrator.

"Site" means the land or water area where any water pollution control facility or activity is physically located or conducted, including adjacent land used in connection with the facility or activity.

"Waters of the State" or "Water" means all surface water and groundwater of the State of Rhode Island, including all tidewaters, wetlands, land masses partially or wholly submerged in water, and both inter and intrastate bodies of water which are, have been or will be used in commerce. by industry, for the harvesting of fish and wildlife or for recreational purposes.

4.00 Severability. If any provision of these rules and regulations of the application thereof to any person or circumstances is held invalid by a court of competent jurisdiction, the remainder of the rules and regulations shall not be affected thereby.

5.00 Application of these Regulations.

a. These regulations shall be liberally construed to permit the Department to effectuate the purposes of the State law.

b. For the purpose of these regulations, point source discharge may be sampled at the point of discharge and at an appropriate upstream and downstream location as determined by the Department. Discharges from a municipal point source shall be sampled at the point of discharge.

c. Nothing in these rules and regulations shall constrain the Director's power and duty to issue an immediate order pursuant to Section 46-12-10 of the General Laws of Rhode Island.

d. These regulations shall be construed in harmony with and as a supplement to all regulations promulgated by the Department pursuant to Chapters 46-12, 41-17.1 and 42-35 of the General Laws of Rhode Island.

6.00 [Reserved]
7.00 User Fee System. (a) The Director hereby established a system of assessing user fees on those point source dischargers which discharge into the surface waters of the State. Monies derived from the user fee system shall be used exclusively for a pollution monitoring program and shall not be substituted for funds appropriated by the State or Federal Government for similar purposes.

(b) The user fees:

(i) shall be individually based on the need for monitoring a facility's discharges and the potential for environmental degradation which its effluent poses, as determined by the Director. Such determination by the Director shall be set forth in an Annual Fee Assessment Document which the Director will make available for public review and comment prior to the Annual User Fee Assessment date;

(ii) assessed on industrial point source dischargers shall not exceed the rate they would be required to pay for discharging into the nearest publicly owned treatment facility;

(iii) assessed on publicly owned treatment facilities shall not exceed the cost to the State of monitoring such facilities;

(iv) shall be assessed on an annual basis and shall be due and payable in full within forty-five (45) days of the Annual Fee Assessment Date;

(v) shall be pro-rated on a per diem basis if a new source begins discharge operations after the Annual User Fee Assessment Date; and,

(vi) shall be rebated on a per diem basis if a point source permanently ceases all discharge operations after the Annual User Fee Assessment Date.

(c) The Director may at any time prior to the next Annual User Fee Assessment Date, issue a supplemental Fee Assessment Document and assess additional user fees. so long as the total of said user fees does not exceed the provisions in Section 6(b)(ii) and 6(b)(iii), or issue a credit which may be applied to future User Fee charges.

(d) Any person who fails to pay the user fee within forty-five (45) days of the assessment date shall be in violation of these regulations. Each day during which an assessment remains unpaid shall consti* tute a separate violation, which shall subject the violator to the criminal sanctions set forth in Chapter 46-12 of the General Laws of Rhode Island. 
7.00 Pollution Monitoring Program. (a) The Director hereby establishes a pollution monitoring program which is designed to:

(b) The-Director, as part of such program. shall from time to time. establish maximum levels of pollutant discharges and such levels shall be consistent with the terms and conditions of permits issued b)

(i) develop, operate, maintain and en- the Department or the US Environmental force a means of monitoring the discharge Protection Agency.

of pollutants into the surface waters of the

(c) Any person exceeding the maximum! State from point source dischargers;

(ii) assess the overall impact from such these regulations, or as established by discharges; and,

(iii) protect, preserve and upgrade the is subje surface waters into which such discharges one hundred (\$100) dollars per day. iII flow. fine, penalty, assessment or remedy that may be imposed for violation of these regulations, or other State or Federal law or regulations related to the discharge of pollutants into the waters of the State.

8.00 Efiective Date. These rules and regulations shall become effective twenty (20) days following their filing with the Office of the Secretary of State; provided. however, that the annual uset fee shall not become due and owing until thirty (3(1) days following each Annual User Fee A.jsessment Date. 


\title{
RHODE ISLAND PRETREATMENT REGULATIONS
}

\author{
(Rhode Island Department of Environmental Management, Division of Water \\ Resources, Rhode Island Pretreatment Regulations; Adopted June 26, 1984)
}

\section{1 - Purpose and Objectives.}

(a) These regulations establish a state and local pretreatment system in conjunction with the National Pretreatment Standards in order to control pollutants which pass through or interfere with treatment processes in Publicly Owned Treatment Works (POTWs) or which may contaminate sewage sludge. These regulations implement Chapter $46-12$ of the General Laws of Rhode Island in conformance with the Clean Water Act and those regulations and standards promulgated by the United States Environmental Protection Agency (EPA). It imposes responsibilities on the state, local government, industry and the public to help implement pretreatment standards.

(b) These regulations are intended to fulfill three objectives:

(1) to prevent the introduction of pollutants into POTWs which will interfere with the operation of a POTW, including interference with its use or disposal of municipal sludge;

(2) to prevent the introduction of pollutants into POTWs which will pass through the treatment works or otherwise be incompatible with such works; and,

(3) to improve opportunities to recycle and reclaim municipal and industrial wastewaters and sludges.

2 - Authority. These regulations are adopted pursuant to Chapters 46-12, 4217.1 and $42-35$ of the General Laws of Rhode Island.

3 - Severability. If any provision of these rules and regulations or the application thereof to any person or circumstances is held invalid by a court of competent jurisdiction, the remainder of the rules and regulations shall not be affected thereby. The invalidity of any section or sections or parts of any section or sections shall not affect the validity of the remainder of these rules and regulations.

\section{4- Application.}

(a) These regulations shall be liberally construed to permit the Department to effectuate the purposes of the State law and shall be construed in harmony with the Clean Water Act and accompanying Federal regulations.

(b) Upon adoption by EPA or the State of additional or more stringent regulations affecting the Rhode Island Pollutant Discharge Elimination System Permit Program or the pretreatment standards, these rules shall be revised to comply with such new regulations following the notice, hearing and public comment provisions of the Rhode Island Administrative Procedures Act, RIGL 42-35.

(c) These regulations apply to:

(1) pollutants from non-domestic sources covered by Pretreatment Standards which are indirectly discharged into or transported by truck or rail or otherwise introduced into POTWs as defined in Rule 5;

(2) POTWs which receive wastewater from sources subject to National Pretreatment Standards; and,

(3) any new or existing source subject to Pretreatment Standards. National Pretreatment Standards do not apply to sources which Discharge to a sewer which is not connected to a POTW Treatment Plant.

5 - Definitions. For the purpose of this regulation:

(a) Except as discussed below, the general definitions, abbreviations, and methods of analysis set forth in 40 CFR Part 401 shall apply to this regulation.

(b) The term "Act" means Federal Water Pollution Control Act, also known as the Clean Water Act, as amended, 33 U.S.C. 1251, et. seq.

(c) The term "Approval Authority" means the Director.

(d) The term "Approved POTW Pretreatment Program" or "Program" or "POTW Pretreatment Program" means a program administered by a POTW that meets the criteria established in this regulation (Rules 5 and 11) and which has been approved by a Regional Administra. tor or State Director in accordance with Rule 13 of this regulation.

(e) The term "Department" means the Rhode Island Department of Environmental Management.

(f) The term "Director" means the Director of the Department of Environmental Management or any subordinate or subordinates to whom he has delegated the powers and duties vested in him by these regulations.

(g) The term "effluent data" means with reference to the discharge (direct or indirect) of pollutants from any source:

(1) Information necessary to determine the identity, amount, frequency, concentration, temperature, or other characteristics (to the extent related to water quality) of any pollutant which has been discharged by the source (or of any pollutant resulting from any discharge from the source), or any combination of the foregoing:

(2) Information necessary to determine the identity, amount, frequency, concentration, temperature, or other characteristics (to the extent related to water quality) of the pollutants which, under an applicable standard or limitation, the source was authorized to discharge (including, to the extent necessary for such purposes, a description of the manner or rate of operation of the source); and 
(3) A general description of the locations and/or nature of the source to the extent necessary to identify the source and to distinguish it from other sources (including, to the extent necessary for such purposes, a description of the device, installation, or operation constituting the source).

Notwithstanding the above, the following information shall be considered to be "effiuent data" only to the extent necessary to allow the Department to disclose publicly that a source is (or is not) in compliance with an applicable standard or limitation, or to allow the Department to demonstrate the feasibility, practicability, or attainability (or lack thereof) of an existing or proposed standard or limitation:

(a) Information concerning research, or the result of research, on any product, method, device, or installation (or any component thereof) which was produced, developed, installed, and used only for research purposes; and

(b) Information concerning any product, method, device, or installation (or any component thereof) designed and intended to be marketed or used commercially but not yet so marketed or used.

(h) The term "Enforcement Division Director" means one of the Directors of the Enforcement Divisions within the Regional offices of the Environmental Protection Agency or this person's delegated representative.

(i) The term "Indirect Discharge" or "Discharge" means the introduction of pollutants into a POTW from any nondomestic source regulated under section 307(b), (c) or (d) or the Clean Water Act.

(j) The term "Industrial User" or "User" means a source of Indirect Discharge.

(k) The term "Interference" means an inhibition or disruption of the POTW, its treatment processes or operations, or its sludge processes, use or disposal which is a cause of or significantly contributes to either a violation of any requirement of the POTWs RIPDES permit (including an increase in the magnitude or duration of a violation) or to the prevention of sewage sludge use or disposal by the POTW in accordance with the following statutory provisions and regulations or permits issued thereunder (or more stringent State or local regulations): Section 405 of the Clean Water Act, the Solid
Waste Disposal Act (SWDA) (including title II more commonly referred to as the Resource Conservation and Recovery Act (RCRA) and including Rhode Island Rules and Regulations Pertaining to the Disposal and Utilization of Wastewater Treatment Facility Sludge), the Clean Air Act, and the Toxic Substances Control Act. An Industrial User significantly contributes to such a permit violation or prevention of sludge use or disposal in accordance with above-cited authorities whenever such User:

(1) Discharges a daily pollutant loading in excess of that allowed by contract with the POTW or by Federal, State or local law;

(2) Discharges wastewater which substantially differs in nature or constituents from the User's average Discharge; or

(3) Knows or has reason to know that its Discharge, alone or in conjunction with Dischargers from other sources, would result in a POTW permit violation or prevent sewage sludge use or disposal in accordance with the above-cited authorities as they apply to the POTW/ selected method of sludge management.

(1) The term "Municipality" means a city, town, borough, county, parish, district, quasi-governmental corporation, association or other public body created by or under State law and having jurisdiction over disposal of sewage, industrial wastes, or other wastes, or a designated and approved management agency under Section 208 of the Clean Water Act.

(m) The term "National Pretreatment Standard," "Pretreatment Standard," or "Standard" means any regulation containing pollutant discharge limits promulgated by the EPA in accordance with Section 307(b) and (c) of the Clean Water Act, which applies to Industrial Users. This term includes prohibitive discharge limits established pursuant to Rule 7.

(n) The term "New Source" means any building, structure, facility, or installation from which there is or may be a discharge of pollutants, the construction of which commenced after the publication of proposed pretreatment standards under Section 307(c) of the Clean Water Act which will be applicable to such sources if such Standards are thereafter promulgated in accordance with that section.

(o) The terms "NPDES Permit" or "Permit" means a permit issued to a POTW pursuant to Section 402 of the Clean Water Act. (p) The term "Pass Through" means the Discharge of pollutants through the POTW into navigable waters in quantities or concentrations which are a cause of or significantly contribute to a violation of any requirement of the POTWs RIPDES permit (including an increase in the magnitude or duration of a violation). An Industrial User significantly contributes to such permit violation where it:

(1) Discharges a daily pollutant loading in excess of that allowed by contract with the POTW or by Federal, States, or local law;

(2) Discharges wastewater which substantially differs in nature and constituents from the User's average Discharge;

(3) Knows or has reason to know that its Discharge, alone or in conjunction with Dischargers from other sources, would result in a permit violation; or

(4) Knows or has reason to know that the POTWs is, for any reason, violating its final effluent limitations in its permit and that such Industrial User's Discharge from other sources, increases the magnitude or duration of the POTWs violations.

(q) The term "Publicly Owned Treatment Works" or "POTW" means a treatment works as defined by Section 212 of the Clean Water Act, which is owned by a State or municipality. This definition includes any devices and systems used in the storage, treatment, recycling and reclama. tion of municipal sewage or industrial wastes of a liquid nature. It also includes sewers, pipes and other conveyance only if they convey wastewater to a POTW Treatment Plant. The term also means the municipality as defined herein, which has jurisdiction over the Indirect Discharges to and the discharges from such a treatment works.

(r) The term "POTW Treatment Plant" means that portion of the POTW which is designed to provide treatment (including recycling and reclamation) of municipal sewage and industrial waste.

(s) The term "Pretreatment" means the reduction of the amount of pollutants, the elimination of pollutants, or the alteration of the nature of pollutant properties in wastewater prior to or in lieu of discharging or otherwise introducing such pollutants into a POTW. The reduction or alteration may be obtained by physical, chemical or biological processes, process changes or by other means, except as prohibited by Rule $8(d)$. Appropriate pretreatment technology includes control 
equipment, such as equalization tanks or facilities, for protection against surges or slug loadings that might interfere with or otherwise be incompatible with the POTW. However, where wastewater from a regulated process is mixed in an equalization facility with unregulated wastewater or with wastewater from another regulated process, the effiuent from the equalization facility must meet an adjusted pretreatment limit calculated in accordance with Rule 8(c).

(t) The term "Pretreatment Requirements" means any substantive or procedural requirement related to Pretreatment, Other than a National Pretreatment Standard, imposed on an Industrial User.

(u) The term "Regional Administrator" means the appropriate EPA Regional Administrator.

(v) The term "Rhode Island Pollutant Discharge Elimination System (RIPDES)" means the Rhode Island system for issuing, modifying, revoking and reissuing, terminating, monitoring and enforcing discharge permits and imposing and enforcing pretreatment requirements pursuant to Title 46 , Chapter 12 of the General Laws of Rhode Island and the Clean Water Act.

(w) The term "Submission" means: 1) a request by a POTW for approval of $a$ Pretreatment Program to the Director; or, 2) a request by a POTW to the Director for authority to revise the discharge limits in categorical Pretreatment Standards to reflect POTW pollutant removals.

6 - Local Law. Nothing in this regulation is intended to affect any Pretreatment Requirements, including any standards or prohibitions, established by local law as long as the local requirements are not less stringent than any set forth in National Pretreatment Standards, or any other requirements or prohibitions established under the Clean Water Act, 40 CFR 403 or this regulation.

7 - National Pretreatment Standards: Prohibited Discharges, (a) General prohibitions. Pollutants introduced into POTWs by an nondomestic source shall not Pass Through the POTW or Interfere with the operation or performance of the works. These general prohibitions and the specific prohibitions in paragraph (b) of this section apply to all non-domestic sources introducing pollutants into a POTW whether or not the source is subject to other National Pretreatment Stan- dards or any national, State, or local Pretreatment Requirements.

(b) Specific porhibitions. In addition, the following pollutants shall not be introduced into a POTW:

(1) Pollutants which create a firo or explosion hazard in the POTW;

(2) Pollutants which will cause corro sive structural damage to the POTW, but in no case Discharges with $\mathrm{pH}$ lower than 5.0 , unless the works is specifically designed to accommodate such Discharges;

(3) Solid or viscous pollutants in amounts which will cause obstruction to the flow in the POTW resulting in Interference;

(4) Any pollutant, including oxygen demanding pollutants (BOD, etc.) released in a Discharge at a flow rate and/or pollutant concentration which will cause Interference with the POTW.

(5) Heat in amounts which will inhibit biological activity in the POTW resulting in Interference, but in no case heat in such quantities that the temperature at the POTW Treatment Plant exceed $40^{\circ} \mathrm{C}$ $\left(104^{\circ} \mathrm{F}\right)$ unless the Approval Authority. upon request of the POTW, approved alternate temperature limits.

(c) When Specific Limits Must be Developed by POTW.

(1) POTWs developing POTW Pretreatment Programs pursuant to Rule 10 shall develop and enforce specific limits to implement the prohibitions listed in Rule $7 \mathrm{a} \& \mathrm{~b}$.

(2) All other POTWs shall, in cases where pollutants contributed by User(s) result in Interference of Pass Through, and such violation is likely to recur, develop and enforce specific effiuent limits for Industrial User(s), and all other-users, as appropriate, which together with appropriate changes in the POTW Treatment Plant's Facilities or operation, are necessary to ensure renewed and continued compliance with the POTWs RIPDES permit and sludge use or disposal practices.

(3) Specific effluent limits shall not be developed and enforced without individual notice to persons or groups who have requested such notice and an opportunity to respond.

(d) Local Limits. Where specific prohibitions or limits on pollutants or pollutant parameters are developed by a POTW in accordance with paragraph (c) above, such limits shall be deemed Pretreatment
Standards for the purposes of Section 307(d) of the Act.

(c) EPA and State Enforcement Actions. If, within $\mathbf{3 0}$ days after notice of an Interference or Pass Through violation has been sent by EPA Or the Department to the POTW, and to persons or groups who have requested such notice, the POTW fails to commence appropriate enforcement action to correct the violation, EPA or the Department may take appropriate enforcement action.

8 - National Pretreatment Standards: Categorical Standarda. National Pretreatment Standards specifying quantities or concentrations of pollutants or pollutant properties which may be Discharged to a POTW by existing or new Industrial Users in specific industrial subcategories will be established as separte regulations under the appropriate subpart of 40 CFR Chapter I, Subchapter N. These Standards, unless specifically noted otherwise, shall be in addition to the general prohibitions established in Rule 7 of this regulation.

(a) Category Determination Request.

(1) Application Deadline. Within 60 days after the effective date of a Pretreatment Standard for a subeategory under which an Industrial User may be included, or within 60 days after the Federal Register notice announcing the availability of the technical development for that subcategory, whichever is later, the POTW may request that the Director provide written certification on whether the Industrial User falls within that particular subcategory. A new source must request this certification prior to commencing discharge. Where a request for certification is submitted by a POTW, the POTW shall notify any affected Industrial User of such submission. The Industrial User may provide written comments on the POTW submission to the Director within 30 days of notification.

(2) Contents of Application. Each request shall contain a statement:

(i) Describing which subcategories might be applicable; and

(ii) Citing evidence and reasons why a particular subcategory is applicable and why others are not applicable. Each such statement shall contain an oath stating that the facts contained therein are true on the basis of the applicant's personal knowledge or to the best of his information and belief. The oath shall be that set forth in Rule 9 (b)(2)(ii), except that the phrase 
"Rule 9" shall be replaced with "Rule 8(a)."

(3) Deficient Requests. The Director will only act on written requests for determinations that contain all of the information required. Persons who have made incomplete submissions will be notified by the Director that their requests are deficient, and unless the time period is extended, will be given 30 days to correct the deficiency. If the deficiency is not corrected within 30 days or within an extended period allowed by the Director, the request for a determination shall be denied.

(4) Final Decision.

(i) When the Director receives a submittal he or she will, after determining that it contains all of the information required by paragraph (2) of this section, consider the submission, any additional evidence that may have been requested, and any other available information relevant to the request. The Director will then make a written determination of the applicable subeategory and state the reasons for the determination.

(ii) Where the request is submitted to the Director, the Director shall forward the determination described in this paragraph to the Enforcement Division Director who may make a final determination. The Enforcement Division Director may waive receipt of these determinations. If the Enforcement Division Director does not modify the Director's decision within 60 days after receipt thereof, or if the Enforcement Division Director waives receipt of the determination, the Director's decision is final.

(iii) Where the request is submitted by the Industrial User of POTW to the En. forcement Division Director or where the Enforcement Division Director elects to modify the Director's decision, the Enforcement Division Director's decision will be final.

(iv) The Enforcement Division Director, or the Director, as appropriate, shall send a copy of the determination to the affected Industrial User and the POTW. Where the final determination is made by the Enforcement Division Director, he or she shall send a copy of the determination to the Director.

(5) Requests for Hearing and/or Legal Decision. Within 30 days following the date of receipt of notice of the final determination as provided for by paragraph (a)(4)(iv) of this section, the Requester may submit a petition to reconsider or contest the decision to the Regional Administrator who shall act on such petition expeditiously and state the reasons for his or her determination in writing.

(b) Deadlines for Compliance with Categorical Standards. Compliance by existing sources with categorical Pretreatment Standards shall be within 3 years of the date the Standard is effective unless a shorter compliance time is specified in the appropriate subpart of $\mathbf{4 0}$ CFR Chapter I, Subchapter $\mathbf{N}$.

Direct Dischargers with NPDES or RIPDES permits modified or reissued to provide a variance pursuant to section 301 (i)(2) of the Clean Water Act shall be required to meet compliance dates set forth in any applicable categorical Pretreatment Standard. Existing sources which become Industrial Users subsequent to promulgation of an applicable categorical Pretreatment Standard shall be considered existing Industrial Users except where such sources meet the definition of a New Source as defined in Rule 5. Compliance with categorical Pretreatment Standards for New Sources will be required upon promulgation.

(c) Concentration and Mass Limits. Pollutant discharge limits in categorical Pretreatment Standards will be expressed either as concentration or mass limits. Wherever possible, where concentration limits are specified in standards, equivalent mass limits will be provided so that local, State or Federal authorities responsible for enforcement may use either concentration or mass limits. Limits in cato gorical Pretreatment Standards shall apply to the effluent of the process regulated by the Standard, or as otherwise specified by the Standard.

(d) Dilution Prohibited as Substitute for Treatment. Except where expressly authorized to do so by an applicable categorical Pretreatment Standard, no Industrial User shall ever increase the use of process water or, in. any other way, attempt to dilute a Discharge as a partial or complete substitute for adequate treatment to achieve compliance with a categorical Pretreatment Standard. The Control Authority (as defined in Rule 14(a)) may impose mass limitations on Industrial Users which are using dilution to meet applicable Pretreatment Standards or in other cases where the imposition of mass limitations is appropriate. (e) Combined Wastestream Formula. Where process effiluent is mixed prior to treatment with wastewaters other than those generated by the regulated process, fixed alternative discharge limits may be derived by the Control Authority, as defined in Rule 14(a), or by the Industrial User with the written concurrence of the Control Authority. These alternative limits shall be applied to the mixed effiluent. When deriving alternative categorical lim. its, the Control Authority or Industrial User shall calculate both an alternative daily maximum value using the daily maximum value(s) specified in the appropriate categorical Pretreatment Standard(s) and an alternative consecutive sampling day average value using the long-term average value(s) specified in the appropriate categorical Pretreatment Standard(s). The Industrial User shall comply with the alternative daily maximum and long-term average limits fixed by the Control Authority until the Control Authority modifies the limits or approves an Industrial User modification request. Modification is authorized whenever there is a material or significant change in the values used in the calculation to fix alternative limits for the regulated pollutant. An Industrial User must immediately report any such material or significant change to the Control Authority. Where appropriate new alternative categorical limits shall be calculated within 30 days.

(1) Alternative limit calculation. For purposes of these formulas, the "average daily flow" means a reasonable measure of the average daily flow for a 30-day period. For new sources, flows shall be estimated using projected values. The alternative limit for a specified pollutant will be derived by the use of either of the following formulas:

(i) Alternative Concentration Limit:

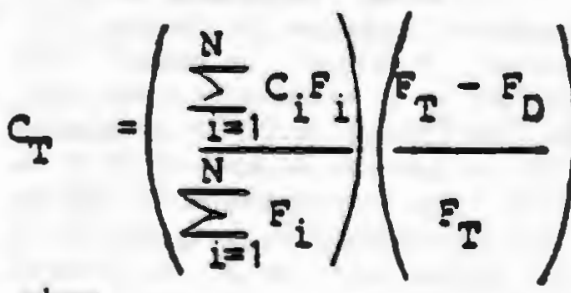

where

$C_{T}=$ the alternative concentration limit for the combined wastestream.

$C_{i}=$ the categorical Pretreatment Standard concentration limit for a pollutant in the regulated stream $i$. 
$F_{i}=$ the average daily flow (at least a 30-day average) of stream $i$ to the extent that it is regulated for such pollutant.

$F_{D}=$ the average daily flow (at least 30-day average) from boiler blowdown streams, non-contact cooling streams, sanitary wastestreams (where such streams are not regulated by a categorical Pretreatment Standard) and from any process wastestreams which were or could have been entirely exempted from categorical Pretreatment Standards pursuant to paragraph 8 of the NRDC v. Costle Consent Decree (12 ERC 1833) for one or more of the following reasons (see Appendix D):

(1) the pollutants of concern are not detectable in the effluent from the Industrial User (paragraph (8)(a)(iii));

(2) the pollutants of concern are present only in trace amounts and are neither causing nor likely to cause toxic effects (peragraph (8)(a)(iii));

(3) the pollutants of concern are present in amounts too small to be effectively reduced by technologies known to the Administrator (paragraph (8)(a)(iii)); or

(4) the wastestream contains only pollutants which are compatible with the POTW paragraph (8)(b)(i).

$F_{T}=$ the average daily flow (at least a 30-day average) through the combined treatment facility (includes $F_{j}, F_{D}$ and unregulated streams).

$N=$ the total number of regulated streams.

(ii) Alternative Mass Limit:

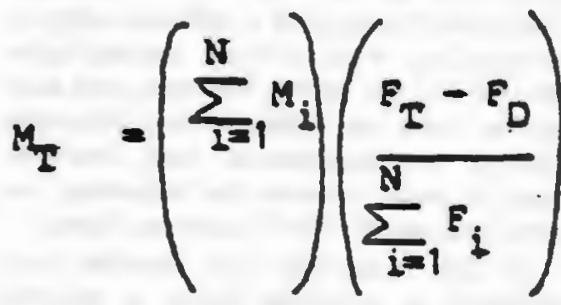

where:

$M_{T}=$ the alternative mass limit for a pollutant in the combined wastestream.

$\mathbf{M}_{\mathbf{i}}$ - the categorical Pretreatment Standard mass limit for a pollutant in the regulated stream i (the categorical pretreatment mass limit multiplied by the appropriate measure of production).

$F_{i}=$ the average flow (at least 30-day average) of stream i to the extent that it is regulated for such pollutant.

$F_{D}=$ the average flow (at least 30-day average) from boiler blowdown streams, non-contact cooling streams, sanitary wastestreams (where such streams are not regulated by a categorical Pretreatment Standard) and from any process wastestreams which were or could have been entirely exempted from categorical Pretreatment Standards pursuant to paragraph 8 of the NRDC v. Costle Consent Decree (12 ERC 1833) for one or more of the following reasons (see Appendix D):

(1) the pollutants of concern are not detectable in the effluent from the Industrial User (paragraph (8)(a)(iii));

(2) the pollutants of cocnern are present only in trace amounts and are neither causing nor likely to cause toxic effects (paragraph (8)(a)(iii)):

(3) the pollutants of concern are present in amounts too small to be effectively reduced by technologies known to the Administrator (paragraph (8)(a)(iii)); or

(4) the wastestream contains only pollutants which are compatible with the POTW (paragraph (8)(b)(i)).

$F_{T}=$ the average flow (at least 30-day average) through the combined treatment facility (includes $F_{i}, F_{D}$ and unregulated streams).

$N=$ the total number of regulated streams.

(2) Alternate Limits Below Detection Limit. An alternatie pretreatment limit may not be used if the alternative limit is below the analytical detection limit for any of the regulated pollutants.

(3) Self-monitoring. Self-monitoring required to insure compliance with the alternative categorical limit shall be as follows:

(i) The type and frequency of sampling, analysis and flow measurement shall be determined by reference to the self-monitoring requirements of the appropriate categorical Pretreatment Standard(s);

(ii) Where the self-monitoring schedules for the appropriate Standards differ, monitoring shall be done according to the most frequent schedule;

(iii) Where flow determines the frequency of self-monitoring in a categorical Pretreatment Standard, the sum of all regulated flows $\left(F_{j}\right)$ is the flow which shall be used to determine self-monitoring frequency.

9 - Revision of Catezorical Pretreatment Standards to Refiect POTW Removal of Pollutants. This section provides the criteria and procedures to be used by a ,POTW in revising the pollutant discharge limits specified in categorical Pretreat- ment Standards to reflect Removal of pollutants by the POTW.

(a) Definitions. For the purpose of this section:

(1) "Removal" shall mean a reduction in the amount of a pollutant in the POTWs effluent or alteration of the nature of a pollutant during treatrient at the POTW. The reduction or alteration can be obtained by physical, chemical or biological means and may be the result of specifically designed POTW capabilities or it may be incidental to the operation of the treatment system. Removal as used in this subpart shall not mean dilution of a pollutant in the POTW. The demonstration of Removal shall consist of data which reflect the Removal achieved by the POTW for those specific pollutants of concern included on the list developed pursuant to Section 307(a) of the Clean Water Act. Each categorical Pretreatment Standard will specify whether or not a Removal Allowance may be granted for indicator or surrogate pollutants regulated in that Standard.

(2) "Consistent Removal" shall mean the average of the lowest 50 percent of the. removals measured according to paragraph (d)(2) of this section. All sample data obtained for the measured pollutant during the time period prescribed in paragraph (d)(2) of this section must be reported and used in computing Consistent Removal. If a substance is measurable in the influent but not in the effluent, the effluent level may be assumed to be the limit of measurement, and those data may be used by the POTW at its discretion and subject to approval by the Director. If the substance is not measurable in the influent, the data may not be used. Where the number of samples with concentrations equal to or above the limit of measurement is between 8 and 12 , the average of the lowest 6 removals shall be used. If there are less than 8 samples with concentrations equal to or above the limit of measurement, the Director may approve alternate means for demonstrating Consistent Removal. The term "measurement" refers to the ability of the analytical method or protocol to quantify as well as identify the presence of the substance in questions.

(3) "Overflow" means the intentional or unintentional diversion of flow from the POTW before the POTW Treatment Plant. 
(b) Revision of Categorical Pretreatment Standards to Reflect POTW Pollutant Removal. Any POTW receiving wastes from an Industrial User to which a categorical Pretreatment Standard applies may, subject to the conditions of this section, revise the discharge limits for a specific pollutant(s) covered in the categorical Pretreatment Standard applicable to that user. Revisions will only be made where the POTW demonstrates Consistent Removal of each pollutant for which the discharge limit in a categorical Pretreatment Standard is to be revised at a level which justifies the amount of revision to the discharge limit. In addition, revision of pollutant discharge limits in categorical Pretreatment Standards by a POTW may only be made provided that:

(1) Application. The POTW applies for, and receives, authorization from the Regional Administrator and/or Director to revise the discharge limits in Pretreatment Standards, for specific pollutants, in accordance with the requirements and procedures set out in this section and Rules II and 13; and

(2) POTW Pretreatment Programs. The POTW has a Pretreatment Program approved in accordance with Ruies 10, 11 and 13: provided. however, a POTW may conditionally revise the discharge limits for specific pollutants even though a Pretreatment Program has not been approved, in accordance with the following terms and conditions. These provisions also govern the issuance of provisional authorizations under Rule 9(d)(2)(vii):

(i) All Industrial Users who wish to receive a conditional or provisional revision of categorical Pretreatment Standards must submit to the POTW the information required in Rule 14(b)(1)-(7) pertaining to the categorical Pretreatment Standard as modified by the conditional or provisional removal allowance, except that the compliance schedule required by Rule $14(b)(7)$ is not required where a provisional allowance is requested. The submission shall indicate what additional technology, if any, will be needed to comply with the categorical Pretreatment Standards as revised by the POTW.

(ii) The POTW must compile and submit data demonstrating removal in accordance with the requirements of paragraphs (d)(1)-(7) of this section. The POTW shall submit to the Director a removal report which comports with the signatory and certification requirements of Rule $14(1)$ and $(\mathrm{m})$. This report shall contain a certification by any of the persons specified in Rule 14 or by an independent engineer containing the following statement: "I have personally examined and am familiar with the information sub. mitted in the attached document, and 1 hereby certify under penalty of law that this information was obtained in accordance with the requirements of Rule $9(d)$. Moreover, based upon my inquiry of those individuals immediately responsible for obtaining the information reported herein, I believe that the submitted information is true, accurate and complete. I am aware that there are significant penalties for sub. mitting false information, including the possibility of fine and imprisonment":

(iii) The POTW must submit to the Director an application for pretreatment program approval meeting the requirements of Rules 10 and 11 (a) or (b) in a timely manner, not to exceed the time limitation set forth in a compliance schedule for development of a pretreatment program included in the POTW's RIPDES permit:

(iv) If a POTW grants conditional or provisional revision(s) and the Director subsequently makes a final determination. after notice and an opportunity for a hearing, that the POTW failed to comply with the conditions in paragraphs (b)(2)(ii) or (iii) of this section, or that its sludge use or disposal practices are not in compliance with the provisions of paragraph (b)(4) of this section, the revision shall be terminated by the Director and all Industrial Users to whom the revised discharge limits has been applied shall achieve compliance with the applicable catcgorical Pretreatment Standard(s) within a reasonable time (not to exceed the period of time prescribed in the applicable categorical Pretreatment Standard(s)) as specified by the Director. However, the revision(s) shall not be terminated where the POTW has not made a timely application for program approval if the POTW has made demonstrable progress towards and has demonstrated and continues to demonstrate an intention to submit an approvable pretreatment program as expeditiously as possible within an additional period of time. not to exceed one year, established by the Director.

(v) If a POTW grants conditional or provisional revision(s) and the POTW or
Director subsequently makes a final determination, after notice and an opportunity for a hearing, that the Industrial User(s) failed to comply with conditions in paragraph (b)(2)(i) of this section, including in the case of a conditional revision, the dates specified in the compliance schedule required by Rule 14(b)(7), the revision shall be terminated by the POTW or the Director for the non-complying Industrial Users and all non-complying Industrial Users to whom the revised discharge limits has been applied shall achieve compliance with the applicable categorical Pretreatment Standard(s) within the time period specified in such Standard(s). The revision(s) shall not be terminated where a violation of the provisions of this subparagraph results from causes entirely outside of the control of the Industrial User or the Industrial User has demonstrated substantial compliance; and

(vi) The POTW shall submit to the Director by December 31 of each year the name and address of each Industrial User that has received a conditionally or provisionally revised discharge limit. If the revised discharge limit is revoked, the POTW must submit the information in paragraph (b)(2)(i) above to the Director.

(3) Compensation for overflow. POTWs which at least annually overflow untreated wastewater to receiving waters may claim Consistent Removal of a pollutant only by complying with either paragraphs (b)(3)(i) or (ii) below. However, this subsection shall not apply where Industrial User(s) can demonstrate that Overflow does not occur between the Industrial User(s) and the POTW. Treatment Plant;

(i) The Industrial User provides containment or otherwise ceases or reduces Discharges from the regulated processes which contain the pollutant for which an allowance is requested during all circumstances in which an overflow event can reasonably be expected to occur at the POTW or at a sewer to which the Industrial User is connected. Discharges must cease or be reduced. or pretreatment must be increased, to the extent necessary to compensate for the removal not being provided by the POTW. Allowances under this provision will only be granted where the POTW submits to the Director evidence that:

(A) All Industrial Users to which the POTW proposes to apply this provision have demonstrated the ability to contain 
or otherwise cease or reduce, during circumstances in which an Overflow event can reasonably be expected to occur. Discharges from the regulated processes which contain pollutants for which an allowance is requested;

(B) The POTW has identified circumstances in which an Overflow event can reasonably be expected to occur, and has a notification or other viable plan to insure that Industrial Users will learn of an im. pending Overflow in sufficient time to contain, cease or reduce Discharging to prevent untreated Overflows from occurring. The POTW must also demonstrate that it will monitor and verify the data required in paragraph $(b)(3)(i)(C)$ herein to insure that Industrial Users are containing, ceasing or reducing operations during POTW System Overflow; and

(C) All Industrial Users to which the POTW proposes to apply this provision have demonstrated the ability and commitment to collect and make available upon request by the POTW, State Director or EPA Regional Administrator daily flow reports or other data sufficient to demonstrate that all Discharges from regulated processes containing the pollutant for which the allowance is requested were contained, reduced or otherwise ceased, as appropriate, during all circumstances in which an Overflow event was reasonably expected to occur: or

(ii)(A) The Consistent Removal claimed is reduced pursuant to the following equation:

$$
r_{c}=r_{m} \frac{8760-z}{8760}
$$

Where:

$r_{m}=$ POTWs Consistent Removal rate for that pollutant as established under paragraphs (a)(1) and (d)(2) of this section

$r_{c}=$ removal corrected by the Overflow factor

$\mathbf{Z}=$ hours per year that Overflow $\propto c$ curred between the Industrial User(s) and the POTW Treatment Plant, the hours either to be shown in the POTWs current RIPDES permit application or the hours, as demonstrated by verifiable techniques, that a particular Industrial User's Discharge Overflows between the Industrial User and the POTW Treatment Plant; and
(B)(1) After July 1, 1983, Consistent Removal may be claimed only where efforts to correct the conditions resulting in untreated Discharges by the POTW are underway in accordance with the policy and procedures set forth in "PRM 75-34" or "Program Guidance Memorandum-61" (same document) published on December 16. 1975 by EPA Office of Water Program Operations (WH-546). (See Appendix A). Revisions to discharge limits in categorical Pretreatment Standards may not be made where efforts have not been committed to by the POTW to minimize pollution from Overflows. At minimum. by July 1, 1983, the POTW must have completed the analysis required by PRM 75-34 and be making an effort to implement the plan.

(2) If, by July 1, 1983, a POTW has begun the PRM 75-34 analysis but due to circumstances beyond its control has not completed it, Consistent Removal, subject to the approval of the Director, may continue to be claimed according to the formula in paragraph (b)(3)(ii)(A) above so long as the POTW acts in a timely fashion to complete the analysis and makes an effort to implement the non-structural cost-effective measures identified by the analysis; and so long as the POTW has expressed its willingness to apply, after completing the analysis, for a construction grant necessary to implement any other cost-effective Overflow controls identified in the analysis should federal funds become availabie, so applies for such funds, and proceeds with the required construction in an expeditious manner. In addition, Consistent Removal may, subject to the approval of the Director, continue to be claimed according to the formula in paragraph (b)(3)(ii)(A) above where the POTW has completed and the Approval Authority has accepted the analysis required by PRM-75-34 and the POTW has requested inclusion in its RIPDES permit of an acceptable compliance schedule providing for timely implementation of costeffective measures identified in the analysis. (In considering what is timely implementation, the Director shall consider the availability of funds, cost of control measures, and seriousness of the water quality problem); and

(4) Compliance with applicable sludge requirements. Such revision will not contribute to the POTWs inability to comply with its RIPDES permit or with the fol-
Jowing statutory provisions and regulations or permits issued thereunder (or more stringent State or lucal regulations) as they apply to the sludge management methods being used: Section 405 of the Clean Water Act; the Solid Waste Disposal Act (SWDA) (including Title II, more commonly referred to as the Resource Conservation Recovery Act (RCRA) and including Rhode Island Rules and Regulations Pertaining to the Disposal and Utilization of Wastewater Treatment Facility Sludge). the Clean Water Act and the Toxic Substances Control Act. The POTW will be authorized to revise discharge limits only for those pollutants that do not contribute to the violation of its RIPDES permit or any of the above statutes.

(c) POTW application for authorization to revise discharge limits.

(1) Application for authorization to revise discharge limits for Industrial Users who are or in the future may be subject to categorical Pretreatment Standards, or approval of discharge limits conditionally or provisionally revised for Industrial Users by the POTW pursuant to paragraphs (b)(2) and (d)(2)(vii) shall be submitted by the POTW to the Director;

(2) Each POTW may submit such an application no more than once per year with respect to either:

(i) any categorical Pretreatment Standard promulgated in the prior 18 months;

(ii) any new or modified facilities or production changes resulting in the Discharge of pollutants which were not previously discharged and which are subject to promulgated categorical Standards; or

(iii) any significant increase in Removal efficiency attributable to specific identifable circumstances or corrective measures (such as improvements in operation and maintenance practices, new treatment or treatment capacity, or a significant change in the influent to the POTW Treatment Plant).

(3) The Director may, however, elect not to review such applications(s) upon receipt, in which case the POTWs conditionally or provisionally revised discharge limits will remain in effect until reviewed by the Director. This review may occur at any time in accordance with the procedures of Rule 13, but in no event later than the time of any pretreatment program approval or any RIPDES permit reissuance thereafter. 
(4) If the Consistent Removal claimed is based on an analytical technique specified for the applicable categorical Pretreatment Standard, the Director may require the POTW perform additional analyses.

(d) Contents of application to revise discharge limits. Requests for authorization to revise discharge limits in categorical Pretreatment Standards must be supported by the following information:

(1) List of Pollutants. A list of pollutants for which discharge limit revisions are proposed.

(2) Consistent Removal Data. Influent and effiuent operational data demonstrat. ing Consistent Removal or other information, as provided for in paragraph (a)(2) of this section, which demonstrates Consistent Removal of the pollutants for which discharge limit revisions are proposed. This data shall meet the following requirements:

(i) Representative Data: Seasonal. The data shall be representative of yearly and seasonal conditions to which the POTW is subjected to each pollutant for which a discharge limit revision is proposed.

(ii) Representative Data: Quality and Quantity. The data shall be representative of the quality and quantity of normal effluent and influent fow if such data can be obtained. If such data are unobtainable, alternate data or information may be presented for approval to demonstrate Consistent Removal as provided for in paragraph (a)(2) of this section.

(iii) Sampling Procedures: Composite.

(A) The influent and effluent operational data shall be obtained through 24-hour flow-proportional composite samples. -Sampling may be done manually or automatically, and discretely or continuously. For discrete sampling, at least 12 aliquots shall be composited. Discrete sampling may be flow-proportioned either by varying the time interval between each aliquot or the volume of each aliquot. All composites must be flow-proportional to either stream flow at time of collection of influent aliquot or to the total influent flow since the previous influent aliquot. Vola. tile pollutant aliquots must be combined in the laboratory immediately before analysis.

(B)(1) Twelve samples shall be taken at approximately equal intervals throughout one full year. Sampling must be evenly distributed over the days of the week so as to include non-workdays as well as work- days. If the Director determines that this schedule will not be most representative of the actual operation of the POTW Treatment Plant, an alternative sampling schedule will be approved.

(2) In addition, upon the Director's concurrence, a POTW may utilize an historical data base amassed prior to the effective date of this section provided that such data otherwise meet the requirements of this paragraph. In order for the historical data base to be approved it must present a statistically valid description of daily, weekly and seasonal sewage treatment plant loadings and performance for at least one year.

(C) Effluent sample collection need not be delayed to compensate for hydraulic detention unless the POTW elects to include detention time compensation or unless the Director requires detention time compensation. The Director may require that each effiuent sample be taken approximately one detention time later than the corresponding influent sample when failure to do so would result in an unrepresentative portrayal of actual POTW operation. The detention period is to be based on a 24 hour average daily flow value. The average daily flow used will be based upon the average of the daily flows during the same month of the previous year.

(iv) Sampling Procedures: Grab. Where composite sampling is not an appropriate sampling technique, a grab sample(s) sha!l be taken to obtain influent and effluent operational data. Collection of influent grab samples should precede collection of effluent samples by approximately one detention period. The detention period is to be based on a 24-hour average daily flow value. The average daily flow used will be based upon the average of the daily flows during the same month of the previous year. Grab samples will be required, for example. where the parameters being evaluated are those, such as cyanide and phenol, which may not be held for any ex. tended period because of biological. chemical or physical interactions which take place after sample collection and affect the results. A grab sample is an individual sample collected over a period of time not exceeding 15 minutes.

(v) Analytical methods. The sampling referred to in paragraphs (d)(2)(i)-(iv) and $(d)(5)$ of this section and an analysis of these samples shall be performed in accordance with the techniques prescribed in 40 CFR Part 136 and amendments thereto. Where 40 CFR Part 136 does not contain sampling or analytical techniques for the pollutant in question, or where the Director determines that the Part 136 sampling and analytical techniques are inappropriate for the pollutant in question, sampling and analysis shall be performed using validated analytical methods or any other applicable sampling and analytical procedures, including procedures suggested by the POTW or other parties, approved by the Administrator.

(vi) Calculation of removal. All data acquired under the provisions of this section must be submitted to the Director. Removal for a specific pollutant shall be determined either, for each sample, by measuring the difference between the concentrations of the pollutant in the influent and effiuent of the POTW and expressing the difference as a percent of the influent concentration, or, where such data cannot be obtained, Removal may be demonstrated using other data or procedures subject to concurrence by the Director as provided for in paragraph (a)(2) of this section.

(vii) Exception to sampling data requirement: provisional removal demonstration. For pollutants which are not currently being discharged (new or modified facilities, or production changes) application may be made by the POTW for provisional authorization to revise the applicable categorical Pretreatment Standard prior to initial discharge of the pollutant. Consistent Removal may be based provisionally on data from treatability studies or demonstrated removal at other treatment facilities where the quality and quantity of influent are similar. In calculating and applying for provisional removal allowances, the POTW must comply with the provisions of paragraphs (b)(1)(4) of this section. Within 18 months after the commencement of Discharge of the pollutants in question, Consistent Removal must be demonstrated pursuant to the requirements of paragraphs $(a)(2)$ and (d)(2)(i)-(vi) of this section.

(3) List of industrial subcategories. A list of the industrial subcategories for which discharge limits in categorical Pretreatment Standards will be revised, shall include the number of Industrial Users in each such subcategory and an identification of which of the pollutants on the list prepared under paragraph (d)(1) of this 
section are Discharged by each subentegory.

(4) Calculation of revised discharge limits. Proposed revised discharge limits for each of the subcategories of Industrial Users identified in paragraph (d)(3) of this section shall be exlculated in the following manner:

(i) The proposed revised discharge limit for a specified pollutant shall be derived by use of the following formula:

$$
y=\frac{x}{1-r}
$$

Where:

$x=$ pollutant discharge limit specified in the applicable categorical Pretreatment Standard

$r=$ POTW $_{s}$ Consistent Removal rate for that pollutant as established under para. graphs (a)(2). (d)(2) and. if appropriate. $(b)(3)(i i)(A)$ of this section. (percentage expressed as a decimal)

$Y=$ revised discharge limit for the specified pollutant (expressed in same units as x)

(ii) In calculating revised discharge limits, such revision for the POTW Removal of a specified poilutant shall be applied equally to all existing and new Industrial Users in an industrial subcategory subject to categorical Pretreatment Standards which discharge that pollutant to the POTW.

(5) Data on sludge characteristics. Duta showing the concentrations and amounts in the POTWS sludge of the pollucants for which discharge limit revisions are proposed and for which EPA. the State or locality have published sludge disposal or use criteria will be applicable to the POTWs current method of sludge use or disposal. These data shall meet the following requirements:

(i) The data shall be obtained through a composite sample taken during the same sampling periods seiected to measure Consistent POTW Removals in accordance with the requirements of paragraph (d)(2) of this section. Each composite sample will contain a minimum of 12 discrere samples taken at equal time intervals over a 24 hour period. Where a composite sample is not an appropriate sampling technique, grab samples shall be taken.

(ii) Sampling and analysis of the samples referred to in paragraph (d)(S)(i) of this section shall be performed in accord- nce with the sampling and analytical techniques described previously in paragraph $(d)(2)(v)$ of this section.

(6) Description of sludge management. A specific description of the POTWs current methods of use or disposal of its sludge and data demonstrating that the current sludge use or disposal methods shall comply and will continue to comply with the requirements of paragraph (b)(4) of this section.

(7) Certification statement. The certifiention statement required by paragraph (b)(2)(ii) of this section shall state that the pollutant Removals and associated re. vised discharged limits have been or will be calculated in accordance with this regulation and any guidelines issued by EPA under Section 304(8) of the Clean Water Act.

(e) Procedure for authorizing modification of standards.

(1) Application for authorization to revise Vational Pretreatment Standards shail comply with Rule II(d) and paragraphs (c) arid (d) of this section. Votice. public comment. and review by the Director shail comply with Rule 13.

(2) POTWs which have received a construction grant from funds authorized for any tiscal year beginning atter September 30. 1978, will only be considered for authorization to modify National Standards after they have completed the analysis required by Section 201(8) of the Clean Water Act and demonstrated that modiñ. cation of the dischurge limits in Vational Standards will not preclude the use of innovative or alternative technology. In addition, where sludge disposal or treatment technology is or will be acquired or constructed with construction grant funds, POTW/s should refer to $\$ 35.917$ (d)(6) and Appendix A of Part 35 of Title 40 of the - Code of Federal Regulations to determine the funding eligibility of sludge disposal or treatment facilities.

(3) The Director shall. at such time as it elects to review the Submission under paragraph (c) of this section, or at the time of POTW pretreatment program approval or RIPDES permit reissuance thereafter, authorize the POTW to revise Industrial User discharge limits, as submitted pursuant to paragraph (d)(4) of this section, which comply with the provisions of this section.

(4) Nothing in these regulations precludes an Industrial User or other interest- ed party from assisting the POTW in preparing and presenting the information necessary to apply for authorization to revise categorical Pretreatment Standards.

(n) Continuation and withdrawal of suthorization.

(1) Monitoring and reporting of consistent removal. Following authotization to revise the discharge limits in Pretreatment Standards, the POTW shall continue to monitor and report on (at such frequencies and over such intervals as may be specified by the Director. but in no case less than two times per year) the POTWs Removal capabilities for all pollutants for which authority to revise the Standards was granted. Such monitoring and reporting shall be in accordance with Rule $14(i)$ and (j) pertaining to pollutant removal capability reports.

(2) Reevaluation of revisions. Approval of authority to revise Pretreatment Standards will be reexamined whenever the POTWis RIPDES permit is reissued. unless the Director determines the need to reevaluate the authority pursuant to paragraph $(\tilde{I})(5)$ of this section. In order to maintain a removal allowance. the POTW. must comply with all iederal. State and local statutes. regulations and permits applicable to the POTW's selected method of sludge use or disposal. In addition. where Overflows of untreated waste by the POTW continue to occur the Director may condition continued authorization to revise discharge limits upon the POTWV performing additional analysis and/or im. plementing such additional control measures as is consistent with EPA policy on POTW Overflows.

(3) Inclusion in POTW permic. Once authority to revise discharge limits for a specified pollutant is grated. the revised discharge limits for Industrial Users of the system as well as the Consistent Removal documented by the POTW for that pollutant and the other requirements of para. graph (b) of this section. shall be included in the POTWs RIPDES Permit upon the earliest reissuance or modification (at or following Program approval) and shall become enforceable requirements of the POTWS RIPDES Permit.

(4) Modification or withdrawal of revised limies.

(i) Notice to POTW. The Director shall notify POTW if, on the basis of pollutant removal capability reports received pursuant to paragraph $(I)(1)$ of this section or 
ther information available to it, the Diector determines:

(A) that one or more of the discharge imit revisions made by the POTW, of the 'OTW itself, no longer meets the requirenents of this section, or

(B) that such discharge limit revisions tre causing or significantly contributing to I violation of any conditions or limits conained in the POTWs RIPDES Permit. A -evised discharge limit is significantly confributing to a violation of the POTWs xermit if it satisfies the definition set forth in Rule $S(j)$ or (0).

(ii) Corrective action. If appropriate corrective action is not taken within a reasonable time, not to exceed 60 days unless the POTW or the affected Industri, al Users demonstrate that a longer time period is reasonably necessary to under. iake the appropriate corrective action. the Director shall either withdraw such discharge limits or require modifications in the revised discharge limits.

(iii) Public notice of withdrawal or modification. The Director shall not with. draw or modify revised discharge limits uniess it shall first have notified the POTW and all Industrial Users to whom revised discharge limits have been applied. and made public. in writing. the reasons for such withdrawal or modification, and an opportunity is provided for a hearing. Following such notice and withdrawal or modification. all Industrial Lisers to whom revised discharge limits had been applied. shall be subject to the modified discharge limits or the discharge limits prescribed in the applicable eategorical Pretreatmen Standards. as appropriate. and shall achieve compliance with such limits within a reasonable time not to exceed the period of time preseribed in the applicable categorical Pretreatment Standard(s). as may be specified by the Director.

(8) Removal allow:ances in pretreatment programs admiñistered by DEM. Where DEM elects to implement a local pretreatment program in lieu of requiring the POTW to develop such a program (see Rule 12) the POTW shall nevertheless responsible for demonstrating Consistent Remoral as provided for in this section. The POTW will nol, however, be required to develop a pretreatment program as a precondition to obtaining approval of the allowance as required by paragraph (b)(2) of this section. Instead, before a removal allowance is approved. the Department will be reguired to demonstrate that suff. cient technical personnel and resources are available to ensure that modified discharge limirs are correctly applied to affeeted Users and that Consistent Removal is maintained.

10 - POTW Pretreatment Programs: Development by POTW.

(a) POTWs required to develop a pretreatment program. Any POTW (or combination of POTWs operated by the same authority) with a total design flow greater than 5 million gallons per day (mgd) and receiving from Industrial Users pollutants which Pass Through or Interfere with the operation of the POTW or are otherwise subject to Pretreatment Standards will be required to establish a POTW Pretreatment Program unless the Department exercises its option to assume local responsibilities as provided for in Rule 12. The Director may require that POTW with a design flow of 5 of mgd or less develop a POTW Pretreatment Program if he or she finds that the nature or volume of the industrial influent, treatment process upsets. violations of POTW-effluent limita. tions. contamination of municipal sludges, or other circumstances warrant, in order to prevent interference with the POTW or Pass Through. In addition, any POTW desiring to modify categorical Pretreatment Standards for pollutants Removed by the POTW: (as provided for by Rule 9) must have an approved POTW Pretreatment Program prior to obtaining final approsal of a removal allowance. POTWs may receive conditional approval of a removal allowiance. as provided for by Rule 9(b)(2). prior to obtaining POTW Pretreatment Program Approval. A POTW may receive Rule $9(\mathrm{~g})$ authority to revise Pretreatment Standards withoui being required to develop a POTW Pretreatment Program winere the Department has assumed responsibility for running a local program in lieu of the POTW in accordance with Rule 12.

(b) Deadline for Program Approval. A POTW which meets the criteria of paragraph (a) of this section must receive approval of a POTW Pretreatment Program no later than 3 years after the reissuance or modification of its existing RIPDES permil. POTW's whose RIPDES permits are modifed under Section 301 (h) of the Clean Water Act shail have a Pretreatment Program within less than 3 years as provided for in 40 CFR Part 125. Subpar G (44 FR 34783 (1979). The POTW Pretreatment Program shall meet the criteris set forth in paragraph (n) of this section and will be administered by the POTW to ensure complinnce by Industrial Users with applicable Pretreatment Standards and Requirements.

(c) Incorporation of approved programs in permits. A POTW may develop an approvable POTW Pretreatment Program any time before the time limit set forth in paragraph (b) of this section and the RIPDES permit will be reissued or modified to incorporate the approved program conditions as enforceable conditions of the permit.

(d) Cause for reissuance or modification of permits. Under the authority of Section 402(b)(1)(C) of the Clean Water Act, the Director may modify, or alternatively, revoke and reissue a POTWs Permit in order to:

(1) put the POTW on a compliance schedule for the development of a POTW Pretreatment Program where the addition of pollutants into a POTW by an Industrial User or combination of Industrial Users presents a substantial hazard to the functioning of the treatment works, quality of the receiving waters, human health, or the environment:

(2) coordinate the issuance of a section 201 construction grant with the incorporation into a permit of a compliance schedule for POTW Pretreatment Program;

(3) incorporate a modification of the permit approved under Sections 30l(h) or 301 (i) of the Clean Wiater Act:

(4) incorporate an approved POTW Pretreatment Program in the POTU permit: or

(5) incorporate a compliance schedule for the development of POTW pretreat. ment program in the POTW permit.

(e) POTW pretreatment program requirements. A POTW: Pretreatment Program shall meet the following requirements:

(1) Legal Authority. The POTW shall operate pursuant to legal authority enforceable in Federal, State or local courts. which authorizes or enables the POTW to apply and to enforce the requirements of sections $307(b)$ and (c). and 402(b)(8) of the Clean Water Act and any regulations implementing these sections. Such authority may be contained in a statute, ordinance, or series of contracts or joint pow. ers agreements which the POTW is authorized to enact. enter into or implement. and which are authorized by State 
law. At a minimum, this legal authority shall enable the POTW to:

(i) Deny or condition new or increased contributions of pollutants, or changes in the nature of pollutants, to the POTW by Industrial Users where such contributions do not meet applicable Pretreatment Standards and Requirements or where such contributions would cause the POTW to violate its RIPDES permit;

(ii) Require compliance with applicable Pretreatment Standards and Requirements by Industrial Users:

(iii) Control, through permit, contract, order, or similar means, the contribution to the POTW by each Industrial User to ensure compliance with applicable Pretreatment Standards and Requirements;

(iv) Require (A) the development of a compliance schedule by each Industrial User for the installation of technology required to meet applicable Pretreatment Standards and Requirements and (B) the submission of all notices and self-monitoring reports from Industrial Users as are necessary to assess and assure compliance by Industrial Users with Pretreatment Standards and Requirements, including but not limited to the reports required in Rule 14.

(v) Carry out inspection, surveillance and monitoring procedures necessary to determine, independent of information supplied by Industrial Users, compliance or noncompliance with applicable Pretreatment Standards and Requirements by Industrial Users. Representatives of the POTW shall be authorized to enter any premises of any Industrial User in which a Discharge source or treatment system is located or in which records are required to be kept under Rule $14(\mathrm{~m})$ to assure compliance with Pretreatment Standards. Such authority shall be at least as extensive as the authority provided under Section 308 of the Clean Water Act;

(vi)(A) Obtain remedies for noncompliance by any Industrial User with any Pretreatment Standard and Requirement. All POTWs shall be able to seek injunctive relief for noncompliance by Industrial Users with Pretreatment Standards and Requirements. In cases where State law has authorized the municipality or POTW to pass ordinances or other local legislation; the POTW shall exercise such authorities by passing legislation to seek and assess civil or criminal penalties for noncompliance by Industrial Users with Pre- treatment Standards and Requirements. POTWs without such authorities shall enter into contracts with Industrial Users to assure compliance by Industrial Users with Pretreatment Standards and Requirements. An adequate contract will provide for liquidated damages for violation of Pretreatment Standards and Requirements and will include an agreement by the Industrial User to submit to the remedy of specific performance for breach of contract.

(B) Pretreatment Requirements which will be enforced through the remedies set forth in paragraph $(\mathrm{e})(\mathrm{I})(\mathrm{vi})(\mathrm{A})$ will include but not be limited to, the duty to allow or carry out inspections, entry, or monitoring activities; any rules, regulations, or orders issued by the POTW; or any reporting requirements imposed by the POTW or these regulations. The POTW shall have authority and procedures (after informal notice to the discharger) immediately and effectively to halt or prevent any Discharge of pollutants to the POTW which reasonably appears to present an imminent endangerment to the health or welfare of persons. The POTW shall also have authority and procedures (which shall include notice to the affected Industrial Users and an opportunity to respond) to halt or prevent any Discharge to the POTW which presents or may present an endangerment to the environment or which threatens to interfere with the operation of the POTW. The Director shall have authority to seek judicial relief for noncompliance by Industrial Users when the POTW has acted to seek such relief but has sought a penalty which the Director finds to be insufficient. The procedures for notice to dischargers where the POTW is seeking ex parte temporary judicial injunctive relief will be governed by applicable state or federal law and not by this provision; and

(vii) Comply with the confidentiality requirements set forth in Rule $\mathbf{1 6}$.

(2) Procedures. The POTW shall develop and implement procedures to ensure compliance with the requirements of a Pretreatment Program. At a minimum, these procedures shall enable the POTW to:

(i) Identify and locate all possible Industrial Users which might be subject to the POTW Pretreatment Program. Any compilation, index or inventory of Industrial Users made under this paragraph shall be made available to the Regional Administrator or Director upon request:

(ii) Identify the character and volume of pollutants contributed to the POTW by the Industrial Users identified under Rule $10(e)(2)(i)$. This information shall be made available to the Regional Administrator or Director upon request;

(iii) Notify Industrial Users identified under Rule $10(e)(2)(i)$ of applicable Pretreatment Standards and any applicable requirements under Section 204(b) and 405 of the Clean Water Act and Subtitles $C$ and $D$ of the Resource Conservation and Recovery Act.

(iv) Receive and analyze self-monitoring reports and other notices submitted by Industrial Users in accordance with the self-monitoring requirements in Rule 14;

(v) Randomly sample and analyze the effiuent from Industrial Users and conduct surveillance and inspection activities in order to identify, independent of information supplied by Industrial Users, occasional and continuing noncompliance with Pretreatment Standards. The results of these activities shall be made available to the Regional Administrator or Director upon request;

(vi) Investigate instances of noncompliance with Pretreatment Standards and Requirements, as indicated in the reports and notices required under Rule 14, or indicated by analysis, inspection, and surveillance activities described in paragraph $(e)(2)(v)$ of this section. Sample taking and analysis and the collection of other information shall be performed with suffcient care to produce evidence admissible in enforcement proceedings or in judicial actions; and

(vii) Comply with the public participation requirements of 40 CFR Part 25 in the enforcement of National Pretreatment Standards. These procedures shall include provision for at least annually providing public notification, in the largest daily newspaper published in the municipality in which the POTW is located, of Industrial Users which, during the previous 12 months, were significantly violating applicable Pretreatment Standards or other Pretreatment Requirements. For the purposes of this provision, a significant violation is a violation which remains uncorrected 45 days after notice of noncompliance; which is part of a pattern of noncompliance; or which resulted in the POTW exercising its emergency authority under Rule 10(e)(1)(iv)(B). 
(3) Funding. The POTW shall have sufficient resources and qualified personnel to carry out the authorities and procedures described in paragraphs $(e)(1)$ and (2) of this section. In some limited cireumstances, funding and personnel may be delayed where (i) the POTW has adequate legal authority and procedures to carry out the Pretreatment Program requirements described in this section, and (ii) a limited aspect of the Program does not need to be implemented immediately.

11 - POTW pretreatment programs and/or authorization to revise pretreatment standards: submission for approval.

(a) Who Approves Program. A POTW requesting approval of a POTW Pretreatment Program shall develop a program description which includes the information set forth in paragraphs (b)(1)-(4) of this section. This description shall be submitted to the Director who will make a determination on the request for program approval in accordance with the procedures described in Rule 13.

(b) Contents of POTW program submission. The program description must contain the following information:

(1) A statement from the City Solicitor or a city official acting in a comparable capacity (or the attorney for those POTWs which have independent legal counsel) that the POTW has authority adequate to carry out the programs described in Rule 10. This statement shall:

(i) Identify the provision of the legal authority under Rule $10(e)(1)$ which provides the basis for each procedure under Rule 10(e)(2).

(ii) Identify the manner in which the POTW will implement the program requirements set forth in Rule 10 including the means by which Pretreatment Standards will be applied to individual Industrial Users (e.g., by order, permit, ordinance, contract. etc.); and.

(iii) Identify how the POTW intends to ensure compliance with Pretreatment Standards and Requirements, and to enforce them in the event of noncompliance by Industrial Users:

(2) A copy of any statutes, ordinances, regulations, contracts, agreements, or other authorities relied upon by the POTW for its administration of the Program. This Submission shall include a statement refiecting the endorsement or approval of the local boards or bodies responsible for supervising and/or funding the POTW Pretreatment Program if approved;
(3) A brief description (including organization charts) of the POTW organization which will administer the Pretreatment Program. If more than one agency is responsible for administration of the Program the responsible agencies should be identified, their respective responsibilities delineated, and their procedures for coordination set forth; and

(4) A description of the funding levels and full - and part-time manpower available to implement the Program;

(c) Conditional POTW program approval. The POTW may request conditional approval of the Pretreatment Program pending the acquisition of funding and personnel for certain elements of the Program. The request for conditional approval must meet the requirements set forth in paragraph (b) of this section except that the requirements of paragraph (b) may be relaxed if the Submission demonstrates that:

(1) A limited aspect of the Program does not need to be implemented immediately:

(2) The POTW has adequate legal authority and procedures to carry out those aspects of the Program which will not be implemented immediately; and

(3) Funding and personnel for the Program aspects to be implemented at a later date will be available when needed. The POTW will describe in the Submission the mechanism by which this funding will be acquired. Upon receipt of a request for conditional approval, the Director will establish a fixed date for the acquisition of the needed funding and personnel. If funding is not acquired by this date, the conditional approval of the POTW Pretreatment Program and any removal allowances granted to the POTW, may be modified or withdrawn.

(d) Content of removal allowance submission. The request for authority to revise categorical Pretreatment Standards must contain the information required in Rule 9(d).

(e) Approval authority action. Any POTW requesting POTW Pretreatment Program approval shall submit to the $\mathrm{Di}$ rector three copies of the Submission described in paragraph (b). and, if appropriate. (d) of this section. Upon a preliminary determination that the Submission meets the requirements of paragraph (b) and, if appropriate, (d), of this section, the Director shall:
(1) Notify the POTW that the Submission has been received and is under review; and

(2) Commence the public notice and evaluation activities set forth in Rule 13.

(I) Notification where submission is defective. If, after review of the Submission as provided for in paragraph (e) of this section, the Director determines that the Submission does not comply with the requirements of paragraphs (b) or (c), and, if appropriate. (d), of this section, the Director shall provide notice in writing to the applying POTW and each person who has requested individual notice. This notification shall identify any defects in the Submission and advise the POTW and each person who has requested individual notice of the means by which the POTW can comply with the applicable requirements of paragraphs (b), (c), and, if appropriate, (d) of this section.

(g) Consistency with water quality management plans.

(1) In order to be approved the POTW Pretreatment Program shall be consistent with any approved water quality management plan developed in accordance with 40 CFR Parts 130, 131, as revised, where such 208 plan includes Management Agency designations and addresses pretreatment in a manner consistent with 40 CFR Part 403. In order to assure such consistency the Director shall solicit the review and comment of the appropriate 208 Planning Agency during the public comment period provided for in Rule 13(b)(1)(ii) prior to approval or disapproval of the Program.

(2) Where no 208 plan has been approved or where a plan has been approved but lacks Management Agency designa. tions and/or does not address pretreatment in a manner consistent with this regulation, the Director shall nevertheless solicit the review and comment of the appropriate 208 planning agency.

\section{State Program in lieu of POTW} Program

Notwithstanding the provision of Rule 10(a). the Department may assume re. sponsibility for implementing the POTW Pretreatment Program requirements set forth in Rule 10(e) in lieu of requiring the POTW to develop a Pretreatment Program. However. this does not preclude POTWs from independently developing Pretreatment Programs. 
13 Approval Procedures for POTW Pretreatment Programs and POTW Revision of Categorical Pretreatment Standards

The following procedures shall be adopted in approving or denying requests for approval of POTW Pretreatment Programs and revising Categorical Pretreatment Standards, including requests for authorization to grant conditional revised discharge limitations and provisional limitations:

(a) Deadline for review of submission. The Director shall have 90 days from the date of public notice of any Submission complying with the requirements of Rule 11 (b) and, where removal allowance approval is sought, with Rule 9 (d) and 11(d), to review the Submission. The Director shall review the Submission to de. termine compliance with the requirements of Rule $10(b)$ and (e), and, where removal allowance approval is sought. with Rule 9(a)-(e) and (g). The Director may have up to an additional 90 days to complete the evaluation of the Submission if the public comment period provided for in paragraph (b)(1)(ii) of this section is extended beyond 30 days or if a public hearing is held as provided for in paragraph (b)(2) of this section. In no event. however, shall the time for evaluation of the Submission exceed a total of 180 days from the date of public notice of a Submission meeting the requirements of Rule 11 (b) and, in the case of removal allowance application, Rules $9(d)$ and 11 (d).

(b) Public notice and opportunity for hearing. Upon receipt of a Submission the Director shall commence its review. Within 5 days after making a determination that a Submission meets the requirements of Rule 11(b), and,. where removal allowance approval is sought, Rules 9(d) and $11(\mathrm{~d})$, or at such later time under Rule $9(\mathrm{c})$ that the Director elects to review the removal allowance Submission, the Director shall:

(1) Issue a public notice of request for approval of the Submission;

(i) This public notice shall be circulated in a manner designed to inform interested and potentially interested persons of the Submission. Procedures for the circulation of public notice shall include:

(A) Mailing notices of the request for approval of the Submission to designated 208 planning agencies, Federal and State fish, shellfish, and wildlife resource agen- cies; and to any other person or group who has requested individual notice, including those on appropriate mailing lists; and

(B) Publication of a notice of request for approval of the Submission in the largest daily newspaper within the jurisdiction(s) served by the POTW.

(ii) The public notice shall provide a period of not less than 30 days following the date of the public notice during, which time interested persons may submit their written views on the Submission.

(iii) All written comments submitted during the 30 day comment period shall be retained by the Director and considered in the decision on whether or not to approve the Submission. The period for comment may be extended at the discretion of the Director; and

(2) Provide an opportunity for the applicant, any affected State, any interested State or Federal agency, person or group of persons to request a public hearing with respect to the Submission.

(i) This request for public hearing shall be filed within the 30 day (or extended) comment period described in paragraph (b)(1)(ii) of this section and shall indicate the interest of the person filing such request and the reasons why a hearing is warranted.

(ii) The Director shall hold a hearing if the POTW so requests. In addition, a hearing will be held if there is a significant public interest in issues relating to whether or not the Submission should be approved. Instances of doubt should be resolved in favor of holding the hearing.

(iii) Public notice of a hearing to consider a Submission and sufficient to inform interested parties of the nature of the hearing and the right to participate shall be published in the same newspaper as the notice of the original request for approval of the Submission under paragraph (b)(I)(i)(B) of this section. In addition, notice of the hearing shall be sent to those persons requesting individual notice.

(3) Whenever the Director elects to defer review of a submission which authorizes the POTW to grant conditional revised discharge limits under Rule $9(b)(2)$ and $9(\mathrm{c})$, the Director shall publish public notice of its election in accordance with paragraph (b)(1) of this section.

(c) Director's decision. At the end of the 30 day (or extended) comment period and within the 90 day (or extended) period provided for in paragraph (a) of this section, the Director shall approve or deny the Submission based upon the evaluation in paragraph (a) of this section and taking into consideration comments submitted during the comment period and the record of the public hearing, if held. Where the Director makes a determination to deny the request, the Director shall so notify the POTW and each person who has requested individual notice. This notification shall include suggested modifications and the Director may allow the requestor additional time to bring the Submission into compliance with applicable requirements.

(d) EPA objection to Director's decision. No POTW pretreatment program or authorization to grant removal allowances shall be approved by the Director if following the 30 day (or extended) evaluation period provided for in paragraph (b)(1)(ii) of this section and any hearing held pursuant to paragraph (b)(2) of this section the Regional Administrator sets forth in writing objections to the approval of such Submission and the reasons for such objections. A copy of the Regional Administrator's objections shall be provided to the applicant, and each person who has requested individual notice. The Regional Administrator shall provide an opportunity for written comments and may convene a public hearing on his or her objections. Unless retracted, the Regional Administrator's objections shall constitute a final ruling to deny approval of a POTW pretreatment program or authorization to grant removal allowances 90 days after the date the objections are issued.

(e) Notice of decision. The Director shall notify those persons who submitted comments and participated in the public hearing, if held, of the approval or disapproval of the Submission. In addition, the Director shall cause to be published a notice of approval or disapproval in the same newspapers as the original notice of request for approval of the Submission was published. The Director shall identify in any notice of POTW Pretreatment Program approval any authorization to modify categorical Pretreatment Standards which the POTW may make, in accordance with Rule 9 for removal of pollutants subject to Pretreatment Standards.

(f) Public access to submission. The Director shall ensure that the Submission and any comments upon such Submission 
are available to the public for inspection and copying.

14 - Reporting requirements for POTWs and Industrial users

(a) Definition. The term "Control Authority" as it is used in this section refers to:

(1) The POTW if the POTWs Submission for its pretreatment program has been approved in accordance with the requirements of Rule 13; or

(2) The Director, if the Submission has not been approved.

(b) Reporting requirement for industrial users upon effective date of eategorical pretreatment standard-baseline report. Within 180 days after the effective date of a categorical Pretreatment Standard, or 180 days after the final administrative decision made upon a category determination submission under Rule $8(a)(4)$, whichever is later, existing Industrial Users subject to such categorical Pretreatment Standards and currently discharging to or scheduled to discharge to a POTW shall be required to submit to the Control Authority a report which contains the information listed in paragraph (d)(1)-(7) of this section. Where reports containing this information already have been submitted to the Director or Regional Administrator in compliance with the requirements of 40 CFR 128.140 (b). (38 Federa) Register 30984, November 8, 1973), the Industrial user will not be required to submit this information again. New sources shall be required to submit to the Control Authority a report which contains the information listed in paragraphs (b)(1)-(5) of this section:

(1) Identifying information. The User - shall submit the name and address of the facility including the name of the operator and owners:

(2) Permits. The User shall submit a list of any environmental control permits held by or for the facility:

(3) Description of operations. The User shall submit a brief description of the nature, average rate of production, and Standard Industrial Classification of the operation(s) carried out by such Industrial User. This description should include a schematic process diagram which indicates points of Discharge to the POTW from the regulated processes.

(4) Flow measurement. The User shall submit information showing the measured average daily and maximum daily flow, in gallons per day, to the POTW from each of the following:

(i) regulated process streams; and

(ii) other streams as necessary to allow use of the combined wastestream formula of Rule $8(e)$. (See paragraph $(b)(5)(v)$ of this section.)

The Control Authority may allow for verifiable estimates of these flows where justified by cost or feasibility considerations.

(5) Measurement of Pollutants

(i) The user shall identify the Pretreatment Standards applicable to each regu. lated process;

(ii) In addition, the User shall submit the resuits of sampling and analysis identifying the nature and concentration (or mass, where required by the Standard or Control Authority) of regulated pollutants in the Discharge from each regulated process. Both daily maximum and average concentration (or mass, where required) shall be reported. The sample shall be representative of daily operations;

(iii) Where feasible, samples must be obtained through the flow-proportional composite sampling techniques specified in the applicable categorical Pretreatment Standard. Where composite sampling is not feasible, a grab sample is acceptable;

(iv) Where the flow of the stream being sampled is less than or equal to 950,000 liters/day (approximately 250.000gpd), the User must take three samples within a two-week period. Where the flow of the stream being sampled is greater than 950.000 liters/day (approximately 250.000gpd), the User must take six samples within a two-week period;

(v) Samples should be taken immediately downstream from pretreatment facilities if such exist or immediately downstream from the regulated process if no pretreatment exists. If other wastewaters are mixed with the regulated wastewater prior to pretreatment the User should measure the flows and concentrations necessary to allow use of the combined wastestream formula of Rule $8(\mathrm{e})$ in order to evaluate compliance with the Pretreatment Standards. Where an alternate concentration or mass limit has been calculated in accordance with Rule $8(e)$ this adjusted limit along with supporting data shall be submitted to the Control Authority:

(vi) Sampling and analysis shall be performed in accordance with the techniques prescribed in 40 CFR Part 136 and amendments thereto. Where 40 CFR Part 136 does not contain sampling or analytical techniques for the pollutant in question, or where the Director determines that the Part 136 sampling and analytical techniques are inappropriate for the pollutant in question, sampling and analysis shall be performed by using validated analytical methods or any other applicable sampling and analytical procedures, including procedures suggested by the POTW or other parties, approved by the Director.

(vii) The Control Authority may allow the submission of a baseline report which utilizes only historical data so long as the data provides information sufficient to determine the need for industrial pretreatment measures:

(viii) The baseline report shall indicate the time, date and place, of sampling, and methods of analysis, and shall certify that such sampling and analysis is representative of normal work cycies and expected pollutant Discharges to the POTW;

(6) Certification. A statement, reviewed by an authorized representative of the Industrial User (as defined in subparagraph (k) of this section) and certified to be a qualified professional, indicating whether Pretreatment Standards are being met on a consistent basis, and, if not, whether additional operation and maintenance ( $O$ and $M$ ) and/or additional pretreatment is required for the Industrial User to meet the Pretreatment Standards and Requirements; and

(7) Compliance Schedule. If additional pretreatment and/or $O$ and $M$ will be required to meet the Pretreatment Standards; then the shortest schedule by which the Industrial User will provide such additional pretreatment and/or $O$ and $M$ shall be required. The completion date in this schedule shall not be later than the compliance date established for the applicable Pretreatment Standard.

(i) Where the Industrial User's categorical Pretreatment Standard has been modified by a removal allowance (Rule.9), the combined wastestream formula (Rule $8(e))$, and/or a Fundamentally Different Factors variance (Rule 15) at the time the User submits the report required by paragraph (b) of this section, the information required by paragraphs $(b)(6)$ and (7) of this section shall pertain to the modified limits. 
(ii) If. the categorical Pretreatment Standard is modified by a removal allowance (Rule 9), the combined waste. stream formula (Rule $8(e)$ and/or a Fundamentally Different Factors variance (Rule 15) after the User submits the report required by paragraph (b) of this section, any necessary amendments to the information requested by paragraphs (b)(6) and (7) of this section shall be submitted by the User to the Control Authority within 60 days after the modified limit is approved.

(c) Compliance Schedule for Meeting Categorical Pretreatment Standards. The following conditions shall apply to the schedule required by paragraph (b)(7) of this section:

(1) The schedule shall contain increments of progress in the form of dates for the commencement and completion of major events leading to the construction and operation of additional pretreatment required for the Industrial User to meet the applicable categorical Pretreatment Standards (e.g., hiring an engineer, completing preliminary plans, completing final plans, executing contract for major components, commencing construction, completing construction, etc.).

(2) No increment referred to in paragraph (c)(1) of this section shall exceed 9 months.

(3) Not later than 14 days following each date in the schedule and the final date for compliance, the Industrial User shall submit a progress report to the Control Authority including, at a minimum, whether or not it complied with the increment of progress to be met on such date, and, if not, the date on which it expects to comply with this increment of progress. the reason for delay, and the steps being taken by the Industrial User to return the construction to the schedule established. In no event shall more than 9 months elapse between such progress reports to the Control Authority.

(d) Report on compliance with categorical pretreatment standard deadline. Within 90 days following the date for final compliance with applicable categorical Pretreatment Standards or in the case of a New Source following commencement of the introduction of wastewater into the POTW, any Industrial User subject to Pretreatment Standards and Requirements shall submit to the Control Authority a report indicating the nature and concentration of all pollutants in the Discharge from the regulated process which are limited by Pretreatment Standards and Requirements and the average and maximum daily flow for these process units in the Industrial User which are limited by such Pretreatment Standards and Requirements. The report shall state whether the applicable Pretreatment Standards or Requirements are being met on a consistent basis and, if not, what additional $O$ and $M$ and/or pretreatment is necessary to bring the Industrial User into compliance with the applicable Pretreatment Standards or Requirements. This statement shall be signed by an authorized representative of the Industrial User, as defined in paragraph ( $k$ ) of this section, and certified to by a qualified professional.

(e) Periodic reports on continued compliance.

(1) Any Industrial User subject to a categorical Pretreatment Standard, after the compliance date of such Pretreatment Standard, or, in the case of a New Source, after commencement of the discharge into the POTW, shall submit to the Control Authority during the months of June and December, unless required more frequently in the Pretreatment Standard or by the Control Authority or the Director, a report indicating the nature and concentration of pollutants in the effluent which are limited by such categorical Pretreatment Standards. In addition, this report shall include a record of measured or estimated average and maximum daily flows for the reporting period for the Discharge reported in paragraph (b)(4) of this section except that the Control Authority may require more detailed reporting of Hows. At the discretion of the Control Authority and in consideration of such factors as local high or low flow rates, holidays, budget cycles, etc., the Control Authority may agree to alter the months during which the above reports are to be submitted.

(2) Where the Control Authority has imposed mass limitations on Industrial Users as provided for by Rule 8(d), the report required by paragraph (e)(1) of this section shall indicate the mass of pollutants regulated by Pretreatment Standards in the Discharge from the Industrial User.

(f) Notice of slug loading. The Industrial User shall notify the POTW immediately of any slug loading, as defined by Rule 7 (b)(4), by the Industrial User. (g) Monitoring and analysis to demonstrate continued compliance. The reports required in paragraphs (b)(5), (d), and (c) of this section shall contain the results of sampling and analysis of the Discharge. including the flow and the nature and concentration, or production and mass where requested by the Control Authority, of pollutants contained therein which are limited by the applicable Pretreatment Standards. The frequency of monitoring shall be that prescribed in the applicable Pretreatment Standard. All analyses shall be performed in accordance with procedures established by the Administrator pursuant to section 304(g) of the Clean Water Act and contained in 40 CFR Part 136 and amendments thereto or with any other test procedures approved by the Director. Sampling shall be performed in accordance with the techniques approved by the Director. Where 40 CFR Part 136 does not include sampling or analytical techniques for the poilutants in question, or where the Director determines that the Part 136 sampling and analytical techniques are inappropriate for the pollutant in question, sampling and analyses shall be performed using validated analytical methods or any other sampling and ana. lytical procedures, including procedures suggested by the POTW or other parties, approved by the Director.

(h) Compliance schedule for POTWs. The following conditions and reporting requirements shall apply to the compliance schedule for development of an approvable POTW Pretreatment Program required by Rule 10.

(1) The schedule shall contain increments of progress in the form of dates for the commencement and completion of major events leading to the development and implementation of a POTW Pretreatment Program (e.g., acquiring required authorities, developing funding mechanisms, acquiring equipment);

(2) No increment referred to in paragraph $(h)(1)$ of this section shall exceed nine months;

(3) Not later than 14 days following each date in the schedule and the final date for compliance, the POTW shall submit a progress report to the Director including, as a minimum, whether or not it complied with the increment of progress to be met on such date and, if not, the date on which it expects to comply with this increment of progress, the reason for de- 
lay, and the steps taken by the POTW to return to the schedule established. In no event shall more than nine months elapse between such progress reports to the Director.

(i) Initial POTW report on compliance with approved removal allowance. A POTW which has received authorization to modify categorical Pretreatment Standards for pollutants removed by the POTW in accordance with the requirements of Rule 9 must submit to the Director within 60 days after the effective date of a Pretreatment Standard for which authorization to modify has been approved, a report which contains the information required by Rule $9(d)(2),(d)(5)$ and (d)(6). A minimum of one sample per month during the reporting period is required.

(j) Periodic reports by POTW to demonstrate continued compliance with removal allowance. The reports referred to in paragraph (i) of this section will be submitted to the Director at 6-month intervals beginning with the submission of the initial report referred to in paragraph (i) of this section unless required more frequently by the Director.

(k) Signatory requirements for industrial user reports. The reports required by paragraphs (b). (d). and (e), of this section must be signed by an authorized representative of the Industrial User. An authorized representative may be:

(1) A principal executive officer of at least the level of vice president, if the Industrial User submitting the reports required by paragraphs (b), (d) and (e) of this section is a corporation.

(2) A general partner or proprietor if the Industrial Liser submitting the report required by paragraphs (b). (d) and (e) of this section is a partnership or sole proprietorship respectively.

(3) A duly authorized representative of the individual designated in subparagraph (1) or (2) of this paragraph if such representative is responsible for the overall operation of the facility from which the Indirect Discharge originates.

(1) Signatory requirements for POTW reports. Reports submitted to the Director by the POTW in accordance with paragraphs (h), (i) and (j) of this section must be signed by a principal executive officer, ranking elected official or other duly authorized employee if such employee is responsible for overall operation of the POTW. (m) Provisions governing fraud and false statements. The reports required by paragraphs (b), (d), (e), (h), (i) and (j) of this section shall be subject to the provisions of 18 U.S.C. section 1001 relating to fraud and false statements and the provisions of R.I.G.L. $46-12-14$ and section 309 (c)(2) of the Clean Water Act governing false statements, representations or certifications in reports required under the Act.

(n) Record-keeping requirements.

(1) Any Industrial User and POTW subject to the reporting requirements established in this section shall maintain records of all information resulting from any monitoring activities required by this section. Such records shall include for all samples:

(i) The date, exact place, method, and time of sampling and the names of the person or persons taking the samples;

(ii) The dates analyses were performed;

(iii) Who performed the analyses:

(iv) The analytical techniques/methods used; and

(v) The results of such analyses.

(2) Any Industrial User or POTW subject to the reporting requirements established in this section shall be required to retain for a minimum of 3 years any records of monitoring activities and results (whether or not such monitoring activities are required by this section) and shall make such records available for inspection and copying by the Director and the Regional Administrator (and POTW in the case of an Industrial User). This period of retention shall be extended during the course of any unresolved litigation regarding the Industrial User or POTW or when requested by the Director or the Regional Administrator.

(3) Any POTw to which reports are submitted by an Industrial Liser pursuant to paragraphs (b), (d), and (e) of this section shall retain such reports for a minimum of 3 years and shall make such reports available for inspection and copy. ing by the Director and the Regional Ad. ministrator. This period of retention shall be extended during the course of any unresolved litigation regarding the discharge of pollutants by the Industrial User or the operation of the POTW Pre-treatment Program or when requested by the Director or the Regional Administrator.

15 Variances from categorical pretreatment standards for fundementally difierent factors. (a) Definition. The term "Requester" means an Industrial User or a POTW or other interested person seeking a variance from the limits specified in a categorical Pretreatment Standard.

(b) Purpose and scope. In establishing categorical Pretreatment Standards for existing sources, the EPA will take into account all the information it can collect, develop and solicit regarding the factors relevant to pretreatment standards under section 307(b). In some cases, information which may affect these Pretreatment Standards will not be available, or, for other reasons, will not be considered during their development. As a result, it may be necessary on a case-by-case basis to adjust the limits in categorical Pretreatment Standards, making them either more or less stringent, as they apply to a certain Industrial User within an industrial category or subcategory. This will only be done if data specific to that Industrial User indicates it presents factors fundamentally different from those considered by EPA in developing the limit at issue. Any interested person believing that factors relating to an Industrial User are fundamentally different from the factors considered during deveiopment of a categorical Pretreatment Standard applicable to that User and further, that the existence of those factors justifies a different discharge limit from that specified in the applicable categorical Pretreatment Standard, may, with respect to non-toxic pollutants request a fundamentally different factors variance under this section or such a variance request may be initiated by the EPA.

(c) Criteria.

(1) General criteria. A request for a variance based upon fundamentally different factors shall be approved only with respect to non-toxic pollutants and only if:

(i) There is an applicable categorical Pretreatment Standard which specifically controls the pollutant for which alternative limits have been requested; and

(ii) Factors relating to the discharge controlled by the categorical Pretreatment Standard are fundamentally different from the factors considered by EPA in establishing the Standards; and

(iii) The request for a variance is made in accordance with the procedural requirements in paragraphs $(\mathrm{g})$ and $(\mathrm{h})$ of this section.

(2) Criteria applicable to less stringent limits. A variance request for the estab- 
lishment of limits less stringent than required by the Standard shall be approved only if:

(i) The alternative limit requested is no less stringent than justified by the fundamental difference;

(ii) The alternative limit will not result in a violation of prohibitive discharge standards prescribed by or established under Rule 7.

(iii) The alternative limit will not result in a non-water quality environment impact (including energy requirements) fundamentally more adverse than the impact considered during development of the Pretreatment Standards; and

(iv) Compliance with the Standards (either by using the technologies upon which the Standards are based or by using other control alternatives) would result in either:

(A) A removal cost (adjusted for inflation) wholly out of proportion to the removal cost considered during development of the Standards; or

(B) A non-water quality environmental impact (including energy requirements) fundamentally more adverse than the impact considered during development of the Standards.

(3) Criteria applicable to more stringent limits. A variance request for the establishment of limits more stringent than required by the Standards shall be approved only if:

(i) The alternative limit request is no more stringent than justified by the fundamental difference, and

(ii) Compliance with the alternative limit would not result in either:

(A) A removal cost (adjusted for infiation) wholly out of proportion to the removal cost considered during development of the Standards; or

(B) A non-water quality environmental impact (including energy requirements) fundamentally more adverse than the impact considered during development of the Standards.

(d) Factors considered fundamentally different. Factors which may be considered fundamentally different are:

(1) The nature or quality of pollutants contained in the raw waste load of the User's process wastewater;

(2) The volume of the User's process wastewear and effluent discharged;

(3) Non-water quality environmental impact of control and treatment of the User's raw waste load;
(4) Energy requirements of the application of control and treatment technology;

(5) Age, size, land availability, and configuration as they relate to the User's equipment or facilities; processes employed; process changes; and engineering aspects of the application of control technology;

(6) Cost of compliance with required control technology.

(e) Factors which will not be considered fundamentally different. A variance request or portion of such a request under this section may not be granted on any of the following grounds:

(1) The feasibility of installing the required waste treatment equipment within the time the Act allows:

(2) The assertion that the Standards cannot be achieved with the appropriate waste treatment facilities installed, if such assertion is not based on factors listed in paragraph (d) of this section;

(3) The User's ability to pay for the required waste treatment: or

(4) The impact of a Discharge on the quality of the POTWs receiving waters.

(f) Local law. Nothing in this section shall be construed to impair the right of any locality under section 510 of the Clean Water Act to impose more stringent, limitations than required by Federal or State law.

(B) Application deadline.

(1) Requests for a variance and supporting information must be submitted in writing to the Director.

(2) In order to be considered, request for variances must be submitted within 180 days after the effective date of the categorical. Pretreatment Standard unless the User has requested a categorical determination pursuant to Rule 8(a).

(3) Where the User has requested a categorical determination pursuant to Rule 8(a), the User may elect to await the results of the category determination before submitting a variance request under this section. Where the User so elects, he or she must submit the variance request within 30 days after a final decision has been made on the categorical determination pursuant to Rule $8(a)(4)$.

(h) Contents of submission. Written Submissions for variance request, whether made to the Director must include:
(1) The name and address of the person making the request:

(2) Identification of the interest of the Requester which is affected by the categorical pretreatment Standard for which the variance is requested;

(3) Identification of the POTW currently receiving the waste from the Industrial User for which alternative discharge limits are requested;

(4) Identification of the categorical Pretreatment Standards which are applicable to the Industrial User:

(5) A list of each pollutant or pollutant parameter for which an alternative discharge limit is sought:

(6) The alternative discharge limits proposed by the Requester for each pollutant or pollutant parameter identified in item (5) of this paragraph;

(7) A description of the Industrial User's existing water pollution control facilities:

(8) A schematic flow representation of the Industrial User's water system including water supply, process wastewater systems, and points of Discharge: and

(9) A Statement of facts clearly establishing why the variance request should be approved, including detailed support data. documentation, and evidence necessary to fully evaluate the merits of the request. e.g., technical and economic data collected by the EPA and used in developing each pollutant discharge limit in the Pretreatment Standard.

(i) Deficient requests. The Director will only act on written requests for variances that contain all of the information required. Persons who have made incomplete Submissions will be notified by the Director that their requests are deficient and unless the time period is extended. will be given up to 30 days to correct the deficiency. If the deficiency is not corrected within the time period allowed by the Director, the request for a variance shall be denied.

(j) Public notice. Upon receipt of a complete request, the Director or Enforcement Division Director will provide notice of receipt, opportunity to review the submission, and opportunity to comment.

(1) The public notice shall be circulated in a manner designed to inform interested and potentially interested persons of the request. Procedures for the circulation of public notice shall include mailing notices to: 
(i) The POTW into which the Industrial User requesting the variance discharges;

(ii) Adjoining States whose waters may be affected: and

(iii) Designated 208 planning agencies, Federal and State fish, shellish and wildlife resource agencies; and to any other person or group who has requested individual notice, including those on appropriate mailing lists.

(2) The public notice shall provide for a period not less than 30 days following the date of the public notice during which time interested persons may review the request and submit their written views on the request.

(3) Following the comment period, the Director or Enforcement Division Director will make a determination on the request taking into consideration any comments received. Notice of this final decision shall be provided to the requester (and the Industrial User for which the variance is requested if different), the POTW into which the Industrial User discharges and all persons who submitted comments on the request.

(k) Review of requests by state.

(1) Where the Director finds that fundamentally different factors do not exist, ne may deny the request and notify the requester (and Industrial User where they are not the same) and the POTW of the denial.

(2) Where the Director finds that fundamentally different factors do exist, he shall forward the request, and a recommendation that the request be approved. to the Enforcement Division Director.

(I) Review of request by EPA.

(1) Where the Enforcement Division Director finds that fundamentally different factors do not exist. he shall deny the request for a variance and send a copy of his determination to the Director, to the POTW, and to the Requester (and to the Industrial User, where they are not the same).

(2) Where the Enforcement Division Director finds that fundamentally different factors do exist, and that a partial or full variance is justified, be will approve the variance. In approving the variance, the Enforcement Division Director will:

(i) Prepare recommended alternative discharge limits for the Industrial User either more or less stringent than those prescribed by the applicable categorical
Pretreatment Standard to the extent warranted by the demonstrated fundamentally different factors;

(ii) Provide the following information in his written determination:

(A) the recommended alternative discharge limits for the Industrial User concerned:

(B) the rationale for the adjustment of the Pretreatment Standard (including the Enforcement Division Director's reason for recommending that a fundamentally different factor variance be granted) and an explanation, of how the Enforcement Division Director's recommended alterna. tive discharge limits were derived;

(C) the supporting evidence submitted to the Enforcement Division Director; and

(D) other information considered by the Enforcement Division Director in developing the recommended alternative discharge limits;

(iii) Notify the Director and the POTW of his or her determination: and

(iv) Send the information described in paragraphs (1)(2)(i) and (ii) above to the Requester (and to the Industrial User where they are not the same).

(m) Request for hearing.

(1) Within $\mathbf{3 0}$ days following the date of receipt of notice of the Enforcement Division Director's decision on a variance request, the Requester or any other interested person may submit a petition to the Regional Administrator for a hearing to reconsider or contest the decision. If such a request is submitted by a person other than the Industrial User the person shall simultaneously serve a copy of the request on the Industrial User.

(2) If the Regional Administrator declines to hold a hearing and the Regional Administrator affirms the Enforcement Division Director's findings, the Requester may submit a petition for a hearing to the Administrator within 30 days of the Regional Administrator's decision.

\section{Confidentiality.}

(a) In accordance with R.I.G.L. 46-12 and the RIPDES permit regulations, "effluent data". permits, or permit application forms submitted to the Director or to a POTW shall be available to the public without restriction.

(b) All other information submitted to the Director or POTW shall be available to the public at least to the extent provided by R.I.G.L. Section 46-12-19.
17 Net/Gross Calculation - Categorical Pretreatment Standards may be adjusted to reflect the presence of poliutants in the Industrial user's intake water in accordance with EPA regional approval pursuant to 40 CFR 403.15 .

18 Upset Provision.

(a) Definition. For the purposes of this section, "Upset" means an exceptional incident in which there is unintentional and temporary noncompliance with categorical Pretreatment Standards because of factors beyond the reasonable control of the Industrial User. An Upset does not include noncompliance to the extent caused by operational error, improperly designed treatment facilities, inadequate treatment facilities, lack of preventive maintenance, or careless or improper operation.

(b) Efiect of an upset. An upset shall constitute an affirmative defense to an action brought for noncompliance with categorical Pretreatment Standards if the requirements of paragraph (c) are met.

(c) Conditions necessary for a demonstration of upset. An Industrial User who wishes to establish the affirmative defense of Upset shall demonstrate, through properly signed, contemporaneous operating logs, or other relevant evidence that:

(1) An Upset occurred and the Industrial User can identify the specific cuuse(s) of the Upset:

(2) The facility was at the time being operated in a prudent and workmanlike manner and in compliance with applicable operation and maintenance procedures;

(3) The Industrial User has submitted the following information to the POTW and Control Authority within 24 hours of becoming aware of the Upset (if this information is provided orally, a written submission must be provided within five days):

(i) A description of the Indirect Discharge and cause of noncompliance:

(ii) The period of noncompliance, including exact dates and times or, if not corrected, the anticipated time the noncompliance is expected to continue;

(iii) Steps being taken and/or planned to reduce, eliminate and prevent recurrence of the noncompliance.

(d) Burden of proof. In any enforcement proceeding the Industrial User seeking to establish the occurrence of an Upset shall have the burden of proof.

(e) Reviewability of agency consideration of claims of upset. In the usual 
exercise of prosecutorial discretion, Department enforcement personnel should review any claims that noncompliance was cause by an Upset. No determinations made in the course of the review constitute final Departmental action subject to judicia] review. Industrial Users will have the opportunity for a judicial determination on any claim of Upset only in an enforcement action brought for noncompliance with categorical Pretreatment Standards.

(f) User responsibility in case of upset. The Industrial User shall control production or all Discharges to the extent necessary to maintain compliance with categorical Pretreatment Standards upon reduction, loss, or failure of its treatment facility until the facility is restored or an alternative method of treatment is provided. This requirement applies in the situation where, among other things, the primary source of power of the treatment facility is reduced, lost or fails.

19 Incorporation by Reference. The following Federal regulations which are cited in whole or in part by these regulations along with all Federal categorical effluent guidelines and standards are hereby incorporated by reference. In the event that any of the requirements contained in Rule 1 through 18 shall conflict with the following Federal regulations, then the more stringent standard shall apply. All future additions or amendments to these Federal regulations and Standards are also hereby incorporated by reference in so far as they may be necessary to assure that Rhode Island maintains an approved RIPDES and Pretreatment Program and to assure that Rhode Island continues to secure to the State the benefits of those programs.

40 CFR Parts 25, 125, 128, 130, 131 , 136,403

20 Superseded Rules and Regulations. On the effective date of these rules and regulations, the Wastewater Pretreatment Systems-Approval rules and regulations, adopted on July 1, 1980 shall hereby be revoked.

Appendix A: EPA Program Guidance Memorandum - 61. [Omitted.] 


\title{
RHODE ISLAND PDES REGULATIONS
}

\author{
(Rhode Island Department of Environmental Management, Division of Water \\ Resources, Regulations for the Rhode Island Pollutant Discharge Elimination System; \\ Adopted June 26, 1984)
}

1 - Purpose. It is the purpose of these regulations to restore, preserve, and enchance the quality of the surface waters and to protect the waters from dischargers of pollutants so that the waters shall be available for all beneficial uses and thus protect the public health, welfare and the environment.

2 - Authority. These regulations are adopted pursuant to Chapters 46-12, 42 17.1 and 42.35 of the General Laws of Rhode Island as amended.

3 - Definitions. Whenever used in these regulations, the following terms shall have the following meanings:

"Administration" means the administrator of the United States Environmental Protection Agency (EPA) or an authorized representative.

"Affected person" means a person who has asserted (and not waived or withdrawn) a confidentiality claim covering information submitted to the Department.

"Animal feeding operation" means a lot or facility (other than an aquatic animal production facility) where: 1) animals (other than aquatic animals) have been, or will be stabled or confined and fed or maintained for a total of 45 days or more in any 12-month period, and 2) crops. vegetation, forage, growth or post harvest residues are not sustained in the normal growing season over any portion of the lot or facility. Two or more animal feeding operations under common ownership are considered, for the purposes of these regulations, to be a single animal feeding operation if they adjoin each other or if they use a common area or system for the disposal of pollutants.

"Applicable standards and limitations" means all state, interstate, and federal standards and limitations to which a "discharge" or a related activity is subject under the Federal or State Acts including effluent limitations, water quality standards, standards of performance, toxic effluent standards or prohibitions, "best management practices," and pretreatment standards under Sections 301, 302, 303. $304,306,307,308,403$ and 405 of the Clean Water Act.

"Applicant" means a person who applies for a RIPDES permit. or a Departmental approval pursuant to these regulations.

"Application" means the EPA standard national forms for applying for a permit, including any additions, revisions or modifications to the forms, or forms approved by EPA for use in "approved States," including any approved modifications of revisions.

"Approved program or approved State" means a State or interstate program which has been approved or authorized by EPA under 40 CFR part 123.

"Aquaculture project" means a defined managed water area which uses discharges of pollutants into that designated area for the maintenance or production of harvestable freshwater, estuarine or marine plants and animals. "Designated area", as used in this definition, means the portions of the waters of the state within which the permittee or permit applicant plans to confine the cultivated species, using a method or plan of operation (including but not limited to, physical confinement) which on the basis of reliable scientific evidence, is expected to ensure that specific individual organisms comprising an aquaculture crop will enjoy increased growth attributable to the discharge of pollutants, and be harvestable within a defined geographic area.

"Areawide plan" means any water quality management plan adopted pursuant to
Section 208 of the Federal Clean Water Act.

"Average monthly discharge limitation" means the highest allowable average of "daily discharges" over a calendar month or any 30 consecutive days, calculated as the sum of all daily discharges measured during a calendar month or any $30 \mathrm{con}$ secutive days, divided by the number of daily discharges measured during that month.

"Average weekly discharge limitation" means the highest allowable average of "daily discharges" over a calendar week or any seven consecutive days. calculated as the sum of all daily discharges measured during a calendar week or seven consecutive days, divided by the number of daily discharges measured during that week.

"Best Professional Judgment (BPJ)" means a limitation determined on case-bycase basis on any pollutant, combination of pollutants or practice(s) which is determined necessary to carry out the provisions of the Clean Water Act and Title 46, Chapter 12 of the General Laws of Rhode Island. "Best Professional Judgment" limitations can be used to set Best Available Technology Economically Achievable, Best Conventional Pollutant Control Technology, Best Practicable Control Currently Available, or "Best Management Practices" limitations as defined in the Clean Water Act either in the absence of an applicable promulgated effluent guideline or where promulgated effuent limitation guidelines only apply to certain aspects of the discharger's operation or to certain pollutants.

"Best Management Practices (BMPs)" means schedules of activities, prohibitions of practices, maintenance procedures, and other management practices to prevent or reduce the pollution of waters of the State. 
BMPs also include treatment requirements, operating procedures, and practices to control site runoff, spillage or leaks, sludge or waste disposal, or drainage from raw material storage.

"Biological monitoring method" means a testing method which utilizes any biological system or any of its parts for assessing the presence or effects of one or more pollutants and/or environmental factors, either alone or in combination. Biomonitoring refers to acute toxic bioassays.

"Bypass" means the intentional diversion of wastes from any portion of a wastewater treatment facility.

"CFR" means the Code of Federal Regulations.

"Clean Water Act" means the Federal law enacted under 33 U.S.C. \$1251 et seq. and any amendments thereto.

"Concentrated animal feeding operation" means an "animal feeding operation which meets the criteria in Appendix $B$, or which the Department designates under Rule 27.

"Concentrated aquatic animal production facility" means a hatchery, fish farm, or other facility which meets the criteria in Appendix C or which the Department designates under Rule 28.

"Confidentiality claim" means a claim or allegation that information is entitled to confidential treatment because such information constitutes a trade secret.

"Construction" means any placement, assembly or installation of facilities, equipment or treatment works, site preparation work, including clearing, excavation removal, or modification of existing build. ing. structures or facilities which is necessary for the placement, assembly or installation of new sources facilities, equipment or treatment works, or entering into a binding contractual obligation for the purchase of facilities or equipment which are intended to be used in its operation within a reasonable time. Options to purchase or contracts which can be terminated or modified without substantial loss and contracts for feasibility, engineering and design studies do not constitute a contractual obligation for the purpose of this definition.

"Contiguous zone" means the entire zone established by the United States un. der Article 24 of the Convention on the Territorial Sea and the Contiguous Zone.

"Continuous discharge" means a "discharge" which occurs without interruption throughout the operating hours of the facility, except for infrequent shutdowns for maintenance, process changes, or other similar activities.

"Conventional pollutant" means those pollutants designated under the authority of Section 304(a)(4) of the Clean Water Act.

"Daily discharge" means the "discharge of a pollutant" measured during a calendar day or any 24-hour period that reasonably represents the calendar day for purposes of sampling. For pollutants with limitations expressed in units of mass, the "daily discharge" is calculated as the total mass of the pollutant discharged over the day. For pollutants with limitations expressed in other units of measurement, the "daily discharge" is calculated as the average measurement of the pollutant over the day.

"Department" means the Rhode Island Department of Environmental Management (DEM).

"Director" means the director of the Department of Environmental Management or any subordinate or subordinates to whom he delegated the powers and duties vested in him by these regulations.

"Direct discharge" means the "discharge of a pollutant."

"Discharge" means the addition of any pollutant to waters from any point source.

"Discharge of a pollutant" means any addition of any "pollutant" or combination of pollutants to "waters of the State" from any "point source".

"Discharge Monitoring Report (DMR)" means the EPA uniform national form, including any subsequent additions, revisions or modifications, for the reporting of self-monitoring results by permittees.

"Discharger" means any person, corporation, municipality, sewerage authority or legal entity, who causes, knows of or should have reason to know of, or allows, any discharge.

"District Engineer" means the chief administrative official of the New England Division, Corps of Engineers or an authorized representative.

"Draft permit" means a document prepared under Rule 37 indicating the Department's tentative decision to issue or deny, modify, revoke and reissue, terminate, or reissue a "permit." A notice of intent to terminate a permit and a notice of intent to deny a permit as discussed in
Rule 36 are types of "draft permits." A denial of a request for modification, revocation and reissuance, or termination, as discussed in Rule 36 is not a "draft permit." A "proposed permit" is not a "draft permit."

"Effluent data" means, with reference to any source of discharge of any pollutant:

(1) Information necessary to determine the identity, amount, frequency, concentration, temperature, or other characteristics (to the extent related to water quality) of any pollutant which has been discharged by the source (or of any pollutant resulting from any discharge from the source), or any combination of the foregoing;

(2) Information necessary to determine the identity, amount, frequency, concentration, temperature, or other characteristics (to the extent related to water quality) of the pollutants which, under an applicable standard or limitation, the source was authorized to discharge (including, to the extent necessary for such purpose, a description of the manner or rate of operation of the source); and

(3) A general description of the locations and/or nature of the source to the extent necessary to identify the source and to distinguish it from other sources (including, to the extent necessary for such purposes, a description of the device, installation, or operation constituting the source).

Notwithstanding the above, the following information shall be considered to be "effluent data" only to the extent necessary to allow the Department to disclose publicly that a source is (or is not) in compliance with an applicable standard or limitation, or to allow the Department to demonstrate the feasibility, practicability, or attainability (or lack thereof) of an existing or proposed standard or limitation:

(1) Information concerning research, or the results of research, on any product. method, device, or installation (or any component thereof) which was produced. developed, installed, and used only for research purposes; and

(2) Information concerning any product, method. device, or installation (or any component thereof) designed and intended to be marketed or used commercially but not yet so marketed or used. 
"Effluent limitations" means any restriction imposed by the Director on quantities, discharge rates and concentrations of pollutants which are discharged from point sources into waters of $\mathbf{R}$ hode Island. the United States, the contiguous zone or the ocean.

"Effluent limitation guidelines" means a regulation published by the Administrator under Section 304(b) of the Clean Water Act to adopt or revise "effluent limitations."

"EPA" means the United States Environmental Protection Agency.

"Facility" means any point source or any other activity (including land or appurtenances thereto) that is subject to regulation under the RIPDES permit program.

"General permit" means a RIPDES permit issued under Rule 32 authorizing a category of discharges within a geographic area.

"Groundwater" means water below the land surface in a zone of saturation.

"Hazardous substance" means any substance designated under 40 CFR Part 116 pursuant to Section 311 of the CWA (see Appendix A, Table V).

"Indirect Discharge" means the introduction of pollutants into a POTW from any non-domestic source regulated under section 307 (b). (c) or (d) of the Clean Water Act.

"Interference" means (a) inhibiting or disrupting the operation of a publicly owned treatment works or its treatment process so as to contribute to, or cause a violation of any condition of a State or Federal permit under which the publicly owned treatment works operates; or (b) discharging industrial process wastewater which, in combination with existing domestic flows are of such volume and/or strength as to exceed the domestic treatment process design capacity; or (c) preventing the use or disposal of sludge produced by the publicly owned treatment works in accordance with Section 405 of the Clean Water Act. and regulations. criteria or guidelines developed pursuant to the Federal Resource Conservation and Recovery Act of 1976, (42 U.S.C. \$3251 et seq.) the Federal Clean Air Act (42 U.S.C. 87401 et seq.) and the Federal Toxic Substances Control Act (15 U.S.C. $\$ 2601$ et seq.) and to the extent practicable, the Rhode Island Rules and Regulations Pertaining to the Disposal and Utili- zation of Wastewater Treatment Facility Sludge.

"Interstate agency" means an agency of two or more states established by or under an agreement or compact approved by the Congress, or any other agency of two or more states having substantial powers or duties pertaining to the control of pollution as determined and approved by the Administrator under the appropriate. Act and regulations.

"Log sorting and log storage facilities" means facilities whose discharges result from the holding of unprocessed wood; for example, logs or roundwood with bark or after removal of bark held in self-contained bodies of water (mill ponds or $\log$ ponds) or stored on land where water is applied intentionally on the logs (wet decking). (See 40 CFR Part 429, Subpart $J$ including the effluent limitations guidelines)

"Major facility" means any facility or activity classified as such by the Regional Administrator in conjunction with the Director.

"Maximum daily discharge limitation" means the highest allowable "daily discharge."

"Memorandum of Agreement" means the agreement entered into under the Clean Water Act between the Administrator and the Director, governing the relationship, duties, and rights of the parties in operating a State NPDES program (RIPDES).

"MGD" means million gallons per day.

"Minor facility" means any facility or activity not classified a "major facility" by the Regional Administrator or the Department.

"Monitoring report form" means the DEM standard form; including any subsequent additions, revisions or modifications for the reporting of self-monitoring results by permittees.

"Municipality" means a city, town, borough, county, parish, district, quasi-governmental corporation, association or other public body created by or under State law and having jurisdiction over disposal of sewage, industrial wastes, or other wastes, or a designated and approved management agency under Section 208 of the Clear Water Act.

"National Pollutant Discharge Elimination System (NPDES)" means the national program for issuing, modifying, revoking and reissuing, terminating, monitoring and enforcing permits, and imposing and enforcing pertreatment requirements, under Sections 307, 402, 318, and 405 of the Clean Water Act. The term includes any State program which has been approved by the Administrator

"New discharger" means any building. structure, facility, or installation:

(a) From which there is or may be a "discharge of pollutants"; and

(b) That did not commence the "discharge of pollutants" at a particular "site" prior to August 13, 1979; and

(c) Which is not a "new source", and

(d) Which has never received a finally effective NPDES permit for discharges at that "site". This definition includes an "indirect discharger" which commences discharging into waters of the State after August 13, 1979. It also includes any existing mobile point source (other than an offshore or coastal oil and gas exploratory drilling rig or a coastal oil and gas developmental drilling rig) such as a seafood processing rig, seafood processing vessel, or aggregate plant, that begins discharging at a "site" for which it does not have a permit, and any offshore or coastal mobile oil and gas exploratory drilling rig or coastal mobile oil and gas developmental drilling rig that commences the discharge of pollutants after August 13. 1979, at a "site" under EPA's permitting jurisdiction for which it is not covered by an individual or general permit and which is located in an area determined by the Director in the issuance of a final permit to be an area or biological concern. In determining whether an area is an area of biological concern, the Director shall consider the factors specified in 40 CFR 125.122(a)(1) through (10).

An offshore or coastal mobile exploratory drilling rig or coastal mobile developmental drilling rig will be considered a "new discharger" only for the duration of its discharge in an area of biological concern.

"New Source" means any building, structure, facility, site or installation from which there is or may be a "discharge of pollutants," the construction of which commenced:

(a) after promulgation of standards of performance under Section 306 of the Clean Water Act which are applicable to such sources, or

(b) after proposal of standards of performance in accordance with Section 306 
of the Clean Water Act which are applicable to such sources, but only if the standards are promulgated in accordance with Section 306 within 120 days of their proposal.

"Non-contact cooling water" means water used to reduce temperature for the purpose of cooling. Such waters do not come into direct contact with any raw material, intermediate product (other than heat) or finished product.

"Non-conventional pollutant" means any pollutant not defined as a conventional pollutant or a toxic pollutant (see Appendix A, Table IV).

"Owner or operator" means the owner or operator of any facility or activity subject to these regulations.

"Permit" means an authorization, license or equivalent control document issued by the Department to implement the requirements of these regulations and the Clean Water Act, or previously issued by EPA prior to delegation of the NPDES program to the State of Rhode Island. "Permit" includes a general permit, but does not include any document which has not yet been the subject of final Department action, such as a "draft permit" or "proposed permit."

"Person" means an individual, trust, firm, joint stock company, corporation (including a quasi-governmental corporation) partnership, association, syndicate, municipality, municipal or state agency, fire district, club, non-profit agency or any subdivision, commission, department, bureau. agency or department of state or federal government (including quasi-governmental corporation) or of any interstate body and any agent or employee thereof.

"Point source" means any discernible, confined, and discrete conveyance, including but not limited to any pipe, ditch, channel, tunnel. conduit, well, discrete fissure, container, rolling stock, concentrated animal feeding operation, or vessel, or other floating craft, from which pollutants are or may be discharged. This term does not include return flows from irrigated agriculture.

"Pollutant" means any dredged spoil, solid waste, incinerator residue, sewage, garbage, sewage sludge, munitions, chemical wastes, biological materials, radioactive materials, heat, wrecked or discarded equipment, rock, sand, cellar dirt and industrial, municipal or agricultural waste.
"Pretreatment requirements" means any limitation of prohibition on quantities, quality, rates, and/or concentrations of pollutants directly or indirectly discharge into or transported by truck or rail or otherwise introduced into a publicly owned treatment works that are imposed by federal or state regulation or by publicly owned treatment works.

"Primary industry category" means any industry category listed in Appendix D. Industries may be added to Appendix D by the Director, as he deems appropriate.

"Priority pollutant" means those pollutants listed pursuant to Section 307(a)(1) of the Clean Water Act (see Appendix E).

"Privately owned treatment works" means any device or system which is (a) used to treat wastes from any facility whose operator is not the operator of the treatment works and (b) not a "POTW".

"Process wastewater" means any water which, during manufacturing or processing. comes into direct contact with or results from the production or use of any raw material, intermediate product, finished product, by-product, or waste product.

"Proposed permit" means a RIPDES "permit" which is sent to EPA for review before final issuance by the State. A "proposed permit" is not a "draft permit."

"Proprietary information" means commercial or financial information which is used in one's business and is of a type of customarily held in strict confidence or regarded as privileged and not disclosed to any member of the public by the person to whom it belongs.

"Publicly owned treatment works (POTWs)" means any facility for the treatment of pollutants owned by the state or any political subdivision thereof, municipality, or other public entity, including quasi-governmental corporation. This definition includes sewers. pipes if they convey wastewater to a POTw as well as any equipment, buildings or machinery used in the treatment operation.

"Recommencing discharger" means a source which recommences discharge after terminating operations.

"Regional Administrator" means the Regional Administrator of the appropriate Regional Office of the Environmental Protection Agency or an authorized representative of the Regional Administrator.

"Rhode Island Pollutant Discharge Elimination System (RIPDES)" means the Rhode Island system for issuing, modifying, revoking and reissuing, terminating, monitoring and enforcing discharge permits and imposing and enforcing pretreatment requirements pursuant to Title 46 , Chapter 12 of the General Laws of Rhode Island and the Clean Water Act.

"Rock crushing and gravel washing facilities" means facilities which process crushed and broken stone, gravel, and riprap (see 40 CFR Part 436, Subpart B, including the effluent limitations guidelines).

"Schedule of compliance" means a schedule of remedial measures included in a permit, including an enforceable sequence of interim requirements (for example, actions, operations, or milestone events) leading to compliance with all applicable State and Federal law and regulations.

"Secondary industry category" means any industry category which is not a "primary industry category."

"Secretary" means the Secretary of the Army, acting through the Chief of Engineers.

"Separate storm sewer" means a conveyance or system of conveyances (including pipes, conduits, ditches, and channels) primarily used for collecting and conveying storm water runoff and which is either:

(a) Located in urbanized area as designated by the Bureau of the Census according to the criteria in 39 FR 15202 (May 1. 1974); or

(b) Not located in an urbanized area but designated by the Director pursuant to Rule 31 of these regulations.

"Sewage from vessels" means human body wastes and the wastes from toilets and other receptacles intended to receive or retain body wastes that are discharged from vessels, and regulated under Section 312 of the Clean Water Act or under Rhode Island law.

"Sewage sludge" means the solids, residues, and precipitate separated from or created in sewage by the processes of a "publicly owned treatment works." "Sewage" as used in this definition means any wastes, including wastes from human households, commercial establishments, industries and storm water runoff, that are discharged to or otherwise enter a publicly owned treatment works.

"Site" means the land or water area where any water pollution control facility 
or activity is physically located or conducted, inçluding adjacent land used in connection with the facility or activity.

"Silvicultural point source" means any discemible, confined, and discrete conveyance related to rock crushing, gravel washing. $\log$ sorting, or $\log$ storage facilities which are operated in connection with silvicultural activities and from which pollutants are discharged into waters of the State. The term does not include non-point source silvicultural activities such as nursery operations, site preparation, reforestation and subsequent cultural treatment. thinning, prescribed burning pest and fire control, harvesting operations, surface drainage, or road construction and maintenance from which there is natural runoff. However, some of these activities (such as stream crossing for roads), may involve point source discharges of dredged or fill material which may require a 404 permit pursuant to the Clean Water Act (see 33 CFR Section 209.120 and Part 123, Subpart E).

\section{"State" means the State of Rhode Island.}

"State/EPA Agreement" means and agreement between the Regional Administrator and the State which integrates and coordinates EPA and State activities, responsibilities and programs under the Clean Water Act.

"Storm sewer" means a sewer intended to carry only storm water.

"Storm water" means waters which result primarily from surface runoff and includes street wash water and drainage.

"Surface water" means any "waters of the State" which are not "groundwater."

"Thermal discharge" means that component of any discharge which is comprised of heat, and which shall be limited in accordance with Sections 301, 306, 316 of the Clean Water Act or when determined necessary by the Department.

"Total dissolved solids" means the total dissolved (filterable) solids as determined by use of the method specified in 40 CFR Part 136.

"Total maximum daily load (TMDL)" means the maximum amount of a particular pollutant that may be discharged into a particular stream segment in one day. TMDLs are required for all water quality limited segments but only for those pollu. tants which limit water uses.

"Toxic pollutant" means those pollutants, or combinations of pollutants, including disease causing agents, which after discharge and upon exposure, inges- tion, inhalation, or assimilation into any organism, either directly or indirectly by ingestion through food chains, may, on the basis of information available to the Director cause death, disease, behavioral, abnormalities, cancer, genetic mutations. physiological malfunctions, including malfunctions in reproduction. or physical deformation. in such organisms or their offspring. Toxic pollutants shall include but not be limited to those pollutants identified pursuant to Section 307 of the Clean Water Act (see Appendix A, Tables II and (II).

"Trade secret" means the whole or any portion or phrase of any scientific, technical or otherwise "proprietary information," design. process, procedure, formula, or improvement which is used in one's business and is secret when the owner takes measures to prevent it from becom. ing available to persons other than those selected by the owner to have access there. to for limited purposes. A "Trade Secret" shall not apply to "effluent data" "permits" or "permit application forms".

"Upset" means an exceptional incident in which there is unintentional and temporary noncompliance with technology-based permit effluent limitations because of fac. tors beyond the reasonable control of the permittee. An upset does not include noncompliance to the extent caused by the operational error. improperly designed treatment facilities, inadequate treatment facilities, lack of preventive maintenance, or careless or improper operation.

"Variance" means any mechanism or provision under Sections 301 or 316 of the Clean Water Act or under 40 CFR Part 125 , or in the applicable "effluent limitations guidelines" which allows modification to or waiver of the generally applicable effluent limitation requirements or time deadlines of the Clean Water Act. This includes provisions which allow the establishment of alternative limitations based on fundamentally different factors or on Section $301(\mathrm{c}), 301(\mathrm{~g}), 301(\mathrm{~h})$, 301 (i), or 316(a) of the Clean Water Act.

"Waste load" means the amount of chemical, physical, or biological matter contained within a waste discharge.

"Waste load allocation" means the assignment of maximum waste loads to point-source discharges so as to maintain water quality standards.

"Water quality criteria" means a designated concentration of a constituent that, when not exceeded, will protect an organ- ism. an organismic community or ā prescribed water use or quality.

"Water quality standards" means the physical, chemical, biological and esthetic characteristics of a water body as described by State water quality criteria or the water quality which would result from existing discharges under design conditions, whichever is more stringent as determined by the Department.

"Waters of the State" or "water" means all surface water and groundwater of the State of Rhode island, including alt tidewaters, territorial seas, wetlands, land masses partially or wholly submerged in water, and both inter- and intrastate bodies of water which are, have been or will be used in commerce, by industry, for the harvesting of fish and shellfish or for recreational purposes.

"Wetlands" means those areas that are inundated or saturated by surface or groundwater at a frequency and duration sufficient to support, and that under normal circumstances do support, a prevalence of vegetation typically adapted for life in saturated soil conditions. Wetlands generally include swamps. marshes, bogs, and similar areas.

4 - Severability. If any provision of these rules and regulations or the application thereof to any person or circumstances is held invalid by a court of competent jurisdiction, the remainder of the rules and regulations shall not be affected thereby. The invalidity of any section or sections or parts of any section or sections shall not affect the validity of the remainder of these rules and regulations.

\section{5 - Application.}

(a) These regulations shall be liberally construed to permit the Department to effectuate the purposes of the State law.

(b) The Department may require an applicant to provide additional information where such information is necessary. in the opinion of the Department, to fully disclose all relevant facts concerning the permit application or permit, including proprietary data. The applicant may assert a claim of confidentiality but claims of confidentiality regarding the name and address of any permit applicant or permittee or claims related to effluent data, permits, and permit application forms, including attachments to the forms, will be denied. Any failure to submit such information shall constitute valid cause for denial of the permit or other remedy as provided by law. 
(c) Nothing in these rules and regulaons shall be deemed to interfere with the virector's power and duty to issue an nmediate order pursuant to Section 462-10 of General Laws of Rhode Island.

(d) These regulations and the State connuing planning process, as approved by 'PA under 40 CFR 35.1500 , shall at all mes be construed so as to assure consisency with the Clean Water Act.

\section{6 - General Prohibitions}

A RIPDES permit shall not be issued:

(a) When the conditions of the permit lo not provide for compliance with the tpplicable requirements of the State and =ederal Acts or regulations;

(b) For the discharge of any radiologi:al, chemical, or biological warfare agent or high-level radioactive waste:

(c) When the imposition of conditions :annot ensure compliance with the appli:able water quality requirements of all Iffected states:

(d) When the Regional Administrator 1as objected to the issuance of the permit $n$ accordance with the Memorandum of Agreement:

(e) When, in the judgment of the United States Secretary of the Army, anchorage and navigation in or on any of the waters of the United States could be substantially impaired by the discharge;

(f) For any discharge inconsistent with a plan or plan amendment approved under Section 208(b) of the Clean Water Act;

( 8 ) For any discharge to the territorial sea. the waters of the contiguous zone, or the oceans in the following circumstances: (1) Before the promulgation of guidelines under Section 403(c) of the Clean Water Act (for determining degradation of the waters of the territorial seas. the contiguous zone. and the oceans) unless the Director determines permit issuance to be in the public interest; or

(2) After promulgation of guidelines under Section 403(c) of the Clean Water Act, when insufficient information exists to make a reasonable judgment whether the discharge complies with them.

(h) To a new source or a new discharger, if the discharge from its construction or operation will cause or contribute to the violation of water quality standards. The owner or operator of a new source or new discharger proposing to discharge into a water segment which does not meet applicable water quality standards or is not expected to meet those standards even after the application of the effluent limitations required by Section $301(b)(1)(A)$ and $301(\mathrm{~b})(1)(B)$ of the Clean Water Act, and for which the State or interstate agency has performed a pollutant load allocation for the pollutants to be discharged, must demonstrate, before the close of the public comment period, that:

(1) There are sufficient remaining pollutant load allocations to allow for the discharge; and

(2) The existing dischargers into that segment are subject to compliance schedules designed to bring the segment into compliance with applicable water quality standards.

\section{7 - Conflict of Interest}

(a) Any board or body which approves all or portions of a permit shall not include as a member any person who receives, or has during the previous two years received, a significant portion of income directly or indirectly from permit holders or applicants for a permit.

(b) For the purposes of this section:

(1) "Board of body" includes any individual, including the Director, who has or shares authority to approve all or portions of permits either in the first instance, as modified or reissued, or on appeal.

(2) "Significant portion of income" means 10 percent or more of gross personal income for a calendar year.

(3) "Permit holders or applicants for a permit" does not include any department or agency of state government.

(4) "Income" includes retirement benefits. consultant fees, interest, and stock dividends.

(c) For the purposes of this section, income is not received "directly or indirectly from permit holders or applicants for a permit" when it is derived from mutual fund payments, or from other diversified investments for which the recipient does not know the primary sources of income.

\section{8 - Persons Required to Apply for a RIPDES Permit.}

(a) Any person who discharges or proposes to discharge pollutants into the wa. ters and who does not have an effective permit, shall, except as provided in Rule 9. submit a complete application to the Department.

(b) Any person who had a NPDES permit prior to the effective date of these regulations shall be notified in writing by the Department that the NPDES permit is continued in full force pursuant to Rule 13 of these regulations and that the person must apply for a RIPDES permit in accordance with the schedule for submission of applications in Rule 10(a).

(c) When a facility or activity is owned by one person but it operated by another person, it is the operator's duty to obtain a permit.

9 - Activities Which Do Not Require A RIPDES Permit.

(a) Any discharge of sewage from vessels, effluent from properly functioning marine engines, laundry, shower, and galley sink wastes, or any other discharge incidental to the normal operation of a vessel. This exclusion does not apply to rubbish, trash. garbage, or other such materials discharged overboard, nor to other discharges when the vessel is operating in a capacity other than as a means of transportation such as when used in an energy or mining facility, or when secured to a storage facility or a seafood processing facility. or when secured to the bed of the ocean. contiguous zone or waters of the United States for the purpose of mineral or oil exploration or development.

(b) Any discharge of dredged or fill material into waters of the United States which are regulated under Section 404 of the Clean Water Act.

(c) Any discharge in compliance with the instruction of an On-Scene Coordinator pursuant to 40 CFR 300 (The National Oil and Hazardous Substances Pollution Plan) or 33 CFR 153.305. (Pollution by Oil and Hazardous Substances).

(d) Any introduction of pollutants from nonpoint source agricultural and silvicultural activities. including runoff from orchards. cultivated crops, pastures, range lands, and forest lands but not discharges from concentrated animal feeding oper. ations, discharges from concentrated aquatic animal production facilities, discharges to aquaculture projects, and discharges from irrigated agriculture.

(c) Return flows from irrigated agriculture.

(f) Discharges of pollutants into a privately-owned treatment works, except as the Director may otherwise require to ensure compliance with applicable state and federal law and regulations.

(g) Discharges covered by a general permit pursuant to Rule 32 except that the Director may, pursuant to Rule 54, 
require a person authorized by a general permit to apply for and obtain an individ. ual RIPDES permit.

(h) The introduction of sewage, industrial wastes, or other pollutants into publicly owned treatment works by indirect discharger. Plans or agreements to switch to this method of disposal in the future do not relieve discharger of the obligation to have and comply with permits until all discharges of pollutants into waters of the United States are eliminated. This exclusion does not apply to the introduction of pollutants to privately owned treatment works or to other discharges through pipes, sewers, or other conveyances owned by a State. municipality or other party not leading to treatment works.

(i) Discharges or disposal of pollutants into an underground or subsurface disposal well except that such activity must be approved by the Director pursuant to the R hode Island Underground Injection Control Regulations.

10 - Schedule for Submission of Applications.

(a) Any person who had an NPDES permit prior to the effective date of these regulations shall either apply for a RIPDES permit at least 180 days prior to the scheduled expiration date of the NPDES permit or if the scheduled expiration date has already passed then within 60 days of receiving written notification from the Department that a RIPDES permit application is due.

(b) Any person planning to continue discharging after the expiration date of an existing RIPDES permit must file an application for renewal at least 180 days prior to expiration of the existing permit.

(c) All other applicants for a RIPDES permit(s) shall apply in accordance with these regulations.

11 - Information to be Included in the Application.

11.01 All applications for a RIPDES shall be submitted to: Department of Environmental Management, Division of $\mathrm{Wa}$ ter Resources, 209 Cannon Building. 75 Davis Street, Providence, Rhode Island 02908.

11.02 Any person who discharges or intends to discharge pollutants into the waters of the stae must apply for a RIPDES permit except as otherwise provided in Rule 9. Any person required to have a RIPDES or NPDES permit by these regulations and who is currently dis- charging pollutants into the waters of the state without such permit. may be subject to immediate enforcement action and shall apply for a RIPDES permit within 60 days of the effective date of these regulations. Any person who has a valid NPDES permit shall apply for a RIPDES permit in accordance with the schedule in Rule 10. Pre-application conferences with the Department are strongly recommended. The following information, where applicable. shall be submitted:

(a) Information required for a RIPDES Permit:

(1) State name, mailing address and location of facility. type of waste to be discharged, and the activities conducted by the applicant which require a RIPDES permit.

(2) Provide a brief description of the nature of the business including the Standard Industrial Classification (SIC) codes which best reflect the principal products or services provided by the facility.

(3) The operator's name, address, telephone number, ownership status, and status as Federal. State, private, public or other entity, and whether the facility is located on Indian lands.

(4) Name of applicant's parent corporation.

(5) A listing of all permits, or orders of approval received or applied for by the applicant or its parent corporation at the site.

(6) The expiration date of existing permit or proposed start up date for new source. Applications must be received at least 180 days prior to expiration of existing permits or 180 days before proposed start up for new sources.

(7) A topographic map (or other if a topographic map is unavailable) extending one mile beyond the property boundaries of the squrce, depicting the facility and each of its intake and discharge structures: each of its hazardous waste treatment, storage, or disposal facilities, each well where fluids from the facility are injected underground; and those wells, springs, other surface water bodies, and drinking water wells listed in public records or otherwise known to the applicant in the map area.

(8) Outfall location. Show the location of the discharge(s), treatment facilities and receiving stream on a plot plan prepared by a Licensed Professional Engineer or Land Surveyor, and on a U.S. Geologi- cal Survey (Quadrangle) map. The latitude and longitude for each discharge must be given to the nearest 15 seconds and the name and classification of the receiving water must be provided.

(9) Line Drawing. A line drawing of the water flow through the facility with a water balance, showing operations contributing wastewater to the effluent and treatment units. The water balance must show approximate average flows at intake and discharge points and between units, including treatment units.

(10) Average flows and treatment. A narrative identification of each type of process, operation, or production area which contributes wastewater to the effluent for each outfall, including process wastewater, cooling water, and storm water runoff, the average flow which each process contributes, and a description of the treatment the wastewater receives, including the ultimate disposal of any solid or fluid wastes other than by discharge. Processes, operations, or production areas may be described in general terms (for example, "dye-making reactor", "distillation tower"). For a privately owned treatment works, this information shall include the identity of each user of the treatment works. If discharge is due to rain runoff, state acres of land drained, give runoff coefficient, and calculate flow based on a 10 year storm frequency.

(11) Intermittent flows. If any of the discharges described in paragraph (a) 10 of this section are intermittent or seasonal, a description of the frequency, approximate time of day where practicable. duration and flow rate of each discharge occurrence:

(12) Maximum production. If an effluent guidelines promulgated under Section 304 of the Clean Water Act applies to the applicant and is expressed in terms of production (or other measure of operation), a reasonable measure of the applicant's actual production reported in the units used in the applicable effluent guideline. The reported measure must reflect the actual production of the facility as required by Rule 17.

(13) Improvements. If the applicant is subject to any present requirements or compliance schedules for construction, upgrading or operation of waste treatment equipment, an identification of the abatement requirement, a description of the abatement project, and a listing of the 
required and projected final compliance dates.

(14) Effiuent characteristica Information on the discharge of pollutants specified in this subparagraph. When "quantitative data" for a pollutant is required, the applicant must collect a sample of effluent, analyze it for the pollutant in accordance with analytical methods approved under 40 CFR Part 136 and provide a description of the method. When no analytical method is approved. the applicant must comply with Rule 14.1I(d). The requirements in paragraphs $(a)(14)$ (iii) and (iv) of this section that an applicant must provide quantitative data for certain pollutants known or believed to be present does not apply to pollutants present in a discharge solely as the result of their presence in intake water; however, an applicant must report such pollutants as present and will be required to establish the presence of pollutants in intake water by the appropriate testing or submission of evaluation of intake water. Grab samples must be used for $\mathrm{pH}$, temperature, cyanide. total phenols, residual, chlorine, oil and grease, and fecal coliform and all volatile organics. For all other pollutants, 24-hour composite samples must be used unless otherwise specified by the Department. An applicant is expected to "know or have reason to believe" that a pollutant is present in an effluent based on an evaluation of the expected use. production, or storage of the pollutant, or on any previous analyses for the pollutant. (For example, any pesticide manufactured by $a$ facility may be expected to be present in contaminated storm water runoff from the facility.)

(i) (A) Every applicant must report quantitative data for every outfall for the following pollutants:

(1) Biochemical Oxyden Demand $\left(\mathrm{BOD}_{\mathrm{s}}\right)$ :

(2) Chemical Oxygen Demand:

(3) Total Organic Carbon;

(4) Total Suspended Solids and Total Dissolved Solids;

(5) Ammonia (as N);

(6) Temperature (both winter and summer); and

(7) $\mathrm{pH}$

(B) At the applicant's request, the Department may waive the reporting requirements for one or more of the pollutants listed in paragraph (a)14(i)(A) of this section (ii) Each applicant with processes in one or more primary industry category (see Appendix D) contributing to a discharge must report quantitative data for the following pollutants in each outfall containing process wastewater:

(A) The organic toxic pollutants in the fractions designed in Table 1 of Appendix $\mathbf{A}$ for the applicant's industrial category or categories unless the applicant qualifies as a small business under paragraph (a)(15) of this section. Table II of Appendix $\mathrm{A}$ lists the organic toxic pollutants in each fraction. The fractions result from the sample preparation required by the analytical procedure which uses gas chromatography/mass spectrometry. A determination that an applicant falls within a particular industrial category for the purposes of selecting fractions for testing is not conclusive as to the applicant's inclusion in that category for any other purposes.

(B) The pollutants listed in Table III of Appendix A (the toxic metals, cyanide. and total phenols).

(iii) Each applicant must report for each outfall quantitative data for the following pollutants, if the applicant knows or has reason to believe that the pollutant is discharged from the outfall:

(A) All pollutants listed in Table II or Table III of Appendix A (the toxic pollutants) for which quantitative data is not otherwise required under paragraph (a)(14)(ii) of this section except that an applicant qualifying as a small business under paragraph (a) (15) of this section is not required to analyze for the pollutants listed in Table II of Appendix A (the organic toxic pollutants).

(B) All pollutants in Table IV of Appendix $A$ (certain conventional and non. conventional pollutants).

(iv) Each applicant must indicate whether it knows or has reason to believe that any of the pollutants in Appendix A. Tables $V$ (certain hazardous substances and asbestos) are discharged from each outfall. For every pollutant excepted to be discharged, the applicant must briefly describe the reasons the pollutant is expected to be discharged, and report any quantitative data it has for any pollutant.

(v) Each applicant must report qualitative data, generated using a screening procedure not calibrated with analytical standards. for 2,3,7,8- tetrachlorodibenzop-doxin (TCDD) if it:
(A) Uses or manufactures 2,4,5-trichlorophenoxy acetic acid $(2,4,5-T) ; 2$. (2,4,5-trichlorophenoxy) propanoic acid (Silvex, 2,4,5, TP): 2-(2,4,5-trichlorophenoxy) ethyl 2,2-dichioropropionate (Erbon): O. O-dimethyl O-(2,4,5-trichlorophenyl) phosphorothionate (Ronnel): 2,4,5-trichlorophenol (TCP); or hexachlorophene (HCP); or

(B) Knows or has reason to believe that TCDD is or may be present in an effluent.

(15) Small business exemption. An applicant which qualifies as a small business may be exempt from the requirements in paragraphs (a)(14)(ii)(A) or (a)(14)(iii)(A) of this section to submit quantitative data for the pollutants listed in Table II of Appendix B (the organic toxic pollutants); An applicant may qualify if its gross total annual sales averages less than $\$ 100,000$ per year (in second quarter 1980 dollars). Applicants who feel they qualify should submit a request for exemption to the Department. The Department shall consider the toxicity of the pollutant in making a decision to exempt an applicant pursuant to this paragraph.

(16) Toxics used or manufactured. A listing of any toxic pollutant which the applicant does or expects that it will, during the next 5 years, use or manufacture as an intermediate or final product or byproduct.

(17) Potential discharges. A description of the expected levels of and the reasons for any discharges of pollutants which the applicant knows or has reason to believe will exceed two times the values reported in paragraph (a)(14) of this section over the next 5 years.

(18) Biological toxicity tests. An identification of biological toxicity tests which the applicant knows or has reason to believe have been made within the last 3 years on any of the applicant's discharges or on a receiving water in relation to a discharge.

(19) Contract analyses. If a contract laboratory or consulting firm performed any of the analyses required by paragraph (a)(14) of this section, the identity of each laboratory or firm and the analyses performed.

(20) Additional information. In addition to the information reported on the application form. applicants shall provide to the Department upon the Department's 
request, such other information as the Department may reasonably require to assess the discharges of the facility and to determine whether to issue a RIPDES permit. The additional information may include additional quantitative data and bioassays to assess the relative toxicity of discharges to aquatic life and requirements to determine the cause of the toxicity.

11.03 Application requirements for new and existing concentrated animal feeding operations and aquatic animal production facilities. New and existing concentrated animal feeding operations and concentrated aquatic animal production facilities shall provide the following information:

(a) For concentrated animal feeding operations:

(1) The type and number of animals in open confinement and housed under roof.

(2) The number of acres used for confinement feeding.

(3) The design basis for the runoff diversion and control system, if one exists, including the number of acres of contributing drainage, the storage capacity, and the design safety factor.

(b) For concentrated aquatic animal production facilities:

(1) The maximum daily and average monthly flow from each outfall.

(2) The number of ponds, raceways, and similar structures.

(3) The name of the receiving water and the source of intake water.

(4) For each species of aquatic animals, the total yearly and maximum harvestable weight.

(5) The calendar month of maximum feeding and the total mass of food fed during that month.

11.04 The Department may require that an applicant for a RIPDES permit provide additional data, reports, specifications, plans or other information concerning the existing or proposed pollution control program.

11.05 Recordkeeping. Applicants shall keep records of all data used to complete permit applications and any supplemental information submitted to the Department under these regulations for a period of at least 5 years from the date the application is signed.

11.06 Special provisions for applications for new sources.

(a) The owner or operator of any facility which may be a new source (as defined in Rule 3) must comply with the provisions of this paragraph. (b)( $\Pi$ Before beginning any on-site construction as defined in 40 CFR 122.29, the owner or operator or any facility which may be a new source must submit information to the Director so that he or she can determine if the facility is a new source. The Director may request any additional information needed to determine whether the facility is a new source.

(2) The Director shall make an initial determination whether the facility is a new source within 30 days of receiving all necessary information under paragraph (b)(1) of this section.

(c) The Director shall issue a public notice in accordance with Rule 41 of the new source determination under paragraph (b) of this section.

(d) Any interested person may challenge the Director's initial new source determination by requesting an evidentiary hearing under Rule 49 within 30 days of issuance of the public notice of the initial determintion. The Director may defer the evidentiary hearing on the determination until after a final permit decision is made. and consolidate the hearing on the determination with any hearing on the permit.

12 - Sigmatories to Permit Applications and Reports

(a) Applications. All permit applications shall be signed as follows:

(1) For a corporation: by a responsible corporate officer. For the purpose of this section, a responsible corporate officer means:

(i) A president, secretary, treasurer, or vice-president of the corporation in charge of a principal business function, or any other person who performs similar policyor decision-making functions for the corporation, or

(ii) the manager of one or more manufacturing, production, or operating facilities employing more than 250 persons or having gross annual sales or expenditures exceeding $\$ 25$ million (in second-quarter 1980 dollars), if authority to sign documents has been assigned or delegated to the manager in accordance with corporate procedures.

(2) For a partnership or sole proprietorship: by a general partner or the proprietor, respectively; or

(3) For a municipality, State, Federal, or other public agency: by either a principal executive officer or ranking elected official. For purposes of this section, a principal executive officer of a Federal agency includes: (i) The chief executive officer of the agency, or

(ii) a senior executive officer having responsibility for the overall operations of a principal geographic unit of the agency (e.g., Regional Administrators of EPA).

(b) Reports. All reports required by permits and other information requested by the Director shall be signed by a person described in paragraph (a) of this section, or by a duly authorized representative of that person. A person is a duly authorized representative only if:

(1) The authorization is made in writing by a person described in paragraph (a) of this section:

(2) The authorization specifies either an individual or a position having responsibility for the overall operation of the regulated facility or activity, such as the position of plant manager, operator or a well or a well field, superintendent, or position of equivalent responsibility. (A duly authorized representative may thus be either a named individual or any individual occupying a named position.) and

(3) The written authorization is submitted to the Director.

(c) Changes to authorization. If an authorization under paragraph (b) of this section is no longer accurate because a different individual or position has responsibility for the overall operation of the facility, a new authorization satisfying the requirements of paragraph (b) of this section must be submitted to the Director prior to or together with any reports, information, or applications to be signed by an authorized representative.

(d) Certification. Any person signing a document under paragraphs (a) or (b) of this section shall make the following certification:

I certify under penalty of law that this document and all attachments were prepared under the direction or supervision in accordance with a system designed to assure that qualified personnel properly gather and evaluate the information submitted. Based on my inquiry of the person or persons who manage the system, or those persons directly responsible for gathering the information, the information submitted is, to the best of my knowledge and belief, true, accurate, and complete. I am aware that there are significant penalties for submitting false information. including the possibility of fine and imprisonment for knowing violations. 
13 - Continuntion of NPDES Permit and Expired RIPDES Permits

(a) The conditions of an NPDES permit or an expired RIPDES permit are continued in force until the effective date of a new RIPDES permit if: the permittee has submitted a timely and complete application for a RIPDES permit or an application for renewal of the permit, and the Department through no fault of the permittee, does not issue a new permit with an effective date under Rule 46 on or before the expiration date of the previous permit (e.g. when issuance is impracticable due to time or resource constraints).

(b) Permits continued under this section remain fully effective and enforceable.

(c) Enforcement. When the permittee is not in compliance with the conditions of the expiring or expired permit the Department may choose to do any or all of the following:

(1) Initiate enforcement action based upon the permit which has been continued;

(2) Issue a notice of intent to deny the new permit under Rule 41 . If the permit is denied, the owner or operator would then be required to cease the activities authorized by the continued permit or be subject to enforcement action for operating without a permit;

(3) Issue a new permit with appropriate conditions; or

(4) Take other actions authorized by these regulations or the General Laws of Rhode Island.

14 - Conditions Applicable to All

14.01 All conditions applicable to all permits shall be incorporated into the permit either expressly or by reference. A specific citation to these or other regulations shall be given in the permit. The following conditions apply to all permits:

14.02 Duty to comply

(a) The permittee shall comply with all conditions of this permit. No pollutant shall be discharged more frequently than authorized or at a level in excess of that which is authorized by the permit. The discharge of any pollutant not specifically authorized in the RIPDES permit or listed and quantified in the RIPDES application shall constitute a violation of the permit. Any permit noncompliance constitutes a violation of the State Act or other a uthority of these regulations and is grounds for enforcement action; for permit termina- tion, revocation and reissuance, or modification; or for denial of a permit renewal application.

(b) A permittee shall not achieve any effiuent concentration by dilution. Nor shall a permittee increase the use of process water or cooling water or otherwise attempt to dilute a discharge as a partial or complete substitute for adequate treatment to achieve permit limitations or water quality standards.

(c) The permittee shall comply with applicable effiuent standards or prohibitions established under Section 307(a) of the Clean Water Act for toxic pollutants within the time provided in the regulations that establish these standards or prohibitions, even if the permit has not yet been modified to incorporate the requirement.

14.03 Duty to reapply. If the permittee wishes to continue an activity regulated by a RIPDES permit after the expiration date of the permit, the permittee shall apply for and obtain a new permit.

14.04 Need to halt or reduce not a defense.

(a) It shall not be a defense for a permittee in an enforcement action that it would have been necessary to halt or reduce the permitted activity in order to maintain compliance with the conditions of this permit.

14.05 Duty to mitigate. The permittee shall take all reasonable steps to minimize or prevent any discharge in violation of this permit which has a reasonable likelihood of adversely affecting human health or the environment.

14.06 Proper operation, maintenance. and operator licensing. The permittee shall at all times maintain in good working order and operate as efficiently as possible all treatment works, facilities, and systems of treatment and control (and related appurtenances) for collection and treatment which are installed or used by the permittee for water pollution control and abatement to achieve compliance with the terms and conditions of the permit. Proper operation and maintenance includes but is not limited to effective performance based on designed facility removals, adequate funding. effective management, adequate operator staffing and training and adequate laboratory and process controls including quality assurance procedures as determined to be appropriate by the Director. This provision requires the filing of an Operation and Maintenance Plan which describes backup or auxiliary facilities or similar systems to assure compliance with permit conditions.

14.07 Permit actions. This permit may be modified, revoked and reissued, or terminated for cause. The filing of a request by the permittee for a permit modification, revocation and reissuance, or termination, or a notification of planned changes or anticipated noncompliance, does not stay any permit condition.

14.08 Property rights. This permit does not convey any property rights of any sort, or any exclusive privilege.

14.09 Duty to provide information. The permittee shall furnish to the Department within a reasonable time, any information which the Department may request to determine whether cause exists for modifying, revoking and reissuing, or terminating this permit, or to determine compliance with this permit. The permittee shall also furnish to the Department upon request. copies of records required to be kept by this permit.

14.10 Inspection and entry. The permittee shall allow the Department or an authorized representative, upon the presentation of credentials and other documents as may be required by law to:

(a) Enter upon the permittee's premises where a discharge source is or might be located or in which monitoring equipment or records required by a permit are kept for purposes of inspection. campling or copying:

(b) Have access to and copy, at reasonable times, any records that must be kept under the conditions of this permit;

(c) Inspect at reasonable times any facilities, equipment (including monitoring and control equipment), practices, or operations regulated or required under this permit; and

(d) Sample or monitor at reasonable times, for the purposes of assuring permit compliance or as otherwise authorized by the State Act, any substances or parameters at any location.

14.11 Monitoring and Records

(a) All permits shall specify:

(1) Requirements concerning the proper use, maintenance, and installation, when appropriate, or monitoring equipment or methods (including biological monitoring methods when appropriate):

(2) Required monitoring including type, intervals, and frequency sufficient to yield data which are representative of the moni- 
tored activity including, when appropriate, continuous monitoring:

(3). Applicable reporting requirements based upon the impact of the regulated activity and as specified in these regula. tions but in no case less than once a year.

(b) The permittee shall monitor:

(1) The mass (or other measurement specifed in the permit) for each pollutant limited in the permit;

(2) The volume of effluent discharged from each outfall:

(3) Other measurements as appropriate: including pollutants in internal waste streams, pollutants in intake water for net limitations; frequency, rate of discharge, etc., for noncontinuous discharges; and pollutants subject to notification requirements under Rule 16.01.

(c) Samples and measurements taken for the purpose of monitoring shall be representative of the monitored activity.

(d) All analyses shall be performed in accordance with the analytical test procedures approved under 40 CFR Part 136 or subsequently established by EPA. Where no approved test procedure is available, the applicant must indicate a suitable analytical procedure and must provide the Department with literature references or a detailed description of the procedure. The Department may consider such method as appropriate procedure and may require its use in the RIPDES permit.

14.12 The permittee shall retain records of all monitoring information, including all calibration and maintenance records and all original strip chart recordings for continuous monitoring instrumentation, copies of all reports required by this permit, and records of all data used to complete the application for this permit, for a period of at least 5 years from the date of the sample, measurement, report or application. This period may be extended by request of the Department at any time.

14.13 Records of monitoring information shall include:

(a) The date, exact place, and time of sampling of measurements:

(b) The individual(s) who performed the sampling of measurements;

(c) The date(s) analyses were performed;

(d) The individual(s) who performed the analyses;

(e) The analytical techniques or methods used;

(f) The results of such analyses; and
(8) The volume of effluent discharged at the time of sampling or measurement.

14.14 Monitoring results shall be reported on a Discharge Monitoring Report (DMR) and on the Department's Monitoring Report Form (MRF).

14.15 If the permittee monitors any pollutant more frequently than required by the permit, using test procedures approved under 40 CFR 136 or as specified in the permit, the results of this monitoring shall be included in the calculation and reporting of the data submitted in the DRM and MRF.

14.16 Calculations for all limitations which require averaging of measurements shall utilize an arithmetic mean unless otherwise specified by the Department in the permit.

14.17 Reporting requirements.

(a) Planned changes. The permittee shall give notice to the Department as soon as possible of any planned physical alterations or additions to the permitted facility.

(b) Anticipated noncompliance. The permittee shall give reasonable advance notice to the Department of any planned changes in the permitted facility or activity which may result in noncompliance with permit requirements.

(c) Transfers. The permit is not transferable to any person except after notice to the Department. The Department may require modification, revocation and reissuance of the permit to change the name of the permittee and incorporate such other requirements as may be necessary.

(d) Monitoring reports. Monitoring results shall be reported at the intervals specified in the permit.

(c) Compliance schedules. Reports of compliance or noncompliance with, or any progress reports on, interim and final requirements contained in any compliance schedule of this permit shall be submitted no later than 14 days following each schedule date.

14.18 Reporting.

(a) The permittee shall immediately report any noncompliance which may endanger health or the environment. Any information shall be provided orally when the permittee becomes aware of the circumstances by calling DEM at 277-2234 or 277-2284 at night. At written submission shall also be provided within $\mathbf{5}$ days of the time the permittee becomes aware of the circumstances. The written submission shall contain a description of the noncompliance and its cause; the period of noncompliance, including exact dates and times, and if the noncompliance has not been corrected, the anticipated time it is expected to continue; and steps taken or planned to reduce, eliminate, and prevent reoccurrence of the noncompliance.

(b) The following shall be included as information which must be reported immediately.

(1) Any unanticipated bypass which exceeds any effluent limitation in the permit.

(2) Any upset which exceeds any effluent limitation on the permit.

(3) Violation of a maximum daily discharge limitation for any of the pollutants listed by the Director in the permit

(c) The Director may waive the written report in a case-by-case basis for reports under paragraph (b) of this section if the oral report has been received within 24 hours.

14.19 Other noncompliance. The permittee shall report all instances of noncompliance, not otherwise reported under subsections 14.17 and 14.18 at the time monitoring reports are submitted. The reports shall contain the information required in subsection 14.18 .

14.20 Bypass

(a) Bypass not exceeding limitations. The permittee may allow any bypass to occur which does not cause effluent limitations to be exceeded, but only if it also is for essential maintenance to assure efficient operation. These bypasses are not subject to the provisions of paragraphs (b) and (c) of this section.

(b) Notice.

(1) Anticipated bypass. If the permittee knows in advance of the need for a bypass. it shall submit prior notice, if possible at least ten days before the date of the bypass.

(2) Unanticipated bypass. The permittee shall submit notice of an unanticipated bypass as required in Rule 14.18 (24-hour notice).

(c) Prohibition of bypass.

(1) Bypass is prohibited, and the Director may take enforcement action against a permittee for bypass, unless:

(i) Bypass was unavoidable to prevent loss of life, personal injury, or severe property damage: for purposes of this section "severe property damage" means:

(A) substantial physical damage to property, damage to the treatment facili- 
ties which causes them to become inoperable. or substantial and permanent loss of natural resources which can reasonably be expected to occur in the absence of a bypass. Severe property damage does not mean economic loss caused by delays in production.

(ii) There were no feasible alternatives to the bypass, such as the use of auxiliary treatment facilities, retention of untreated wastes, or maintenance during normal periods of equipment downtime. This condition is not satisfied if the permittee could have installed adequate backup equipment to prevent a bypass which occurred during normal periods of equipment downtime or preventive maintenance; and

(iii) The permittee submitted notices as required under paragraph (b) of this section

(2) The Director may approve an anticipated bypass, after considering its adverse effects, if the Director determines that it will meet the three conditions listed above in paragraph $(c)(1)(i)$ of this section.

\subsection{Upset.}

(a) Effect of an upset. An upset constitutes an affirmative defense to an action brought for noncompliance with such technology based permit effluent limitations if the requirements of paragraph (b) of this section are met. No determination made during administrative review of claims that noncompliance was caused by upset, and before an action for noncompliance, is hinal administrative action subject to judicial review.

(b) Conditions necessary for a demonstration of upset. A permittee who wishes to establish the affirmative defense of upset shall demonstrate through properly signed, contemporaneous operating logs, or other relevant evidence that:

(1) An upset occurred and that the permittee can identify the specific cause(s) of the upset;

(2) The permitted facility was at the time being properly operated;

(3) The permittee submitted notice of the upset as required in Rule 14.18 of this section (24-hour notice); and

(4) The permittee complied with any remedial measures required under Rule 14.05 of this section.

(c) Burden of proof. In any enforcement proceeding the permittee seeking to establish the occurrence of an upset has the burden of proof.
14.22 Other information. Where the permittee becomes aware that it failed to submit any relevant facts in a permit application, or submitted incorrect informa. tion in a permit application or in any report to the Department, the permittee shall promptly submit such facts or information.

\section{5 - Establishing Limitations, Stan-} dards and Other Permit Conditions

15.01 Each permit shall include conditions meeting the following requirements when applicable:

(a) Technology-based effluent limitations and standards based on effluent limitations and standards promulgated under Section 301 of the Clean Water Act or new source performance standards promulgated under Section 306 of the Clean Water Act; or case-by-case effluent limitations determined under Section 402(a)(1) of the Clean Water Act, or on a combination of the two, in accordance with 40 CFR Section 125.3.

(b) Other effluent limitations and standards under Sections 301, 302, 303, 307. 318 and 405 of the Clean Water Act, and 40 CFR Parts 125, 129, 133 and subchapter $N$. If any applicable toxic effluent standard or prohibition (including any schedule of compliance specified in such effluent standard or prohibition) is promulgated under Section 307(a) of the Clean Water Act for a toxic pollutant and that standard or prohibition is more stringent that any limitation on the pollutant in the permit, the Department shall institute proceedings under these regulations to modify or revoke and reissue the permit to conform to the toxic effluent standard or prohibition.

(c) Reopener clause: for any discharger within a primary industry category (see Appendix D), requirements under Section $307(a)(2)$ of the Clean Water Act as follows:

(1) Any permit issued shall include effluent limitations and a compliance schedule to meet the requirements of Sections $301(b)(2)(A),(C),(D),(E)$ and (F) of the Clean Water Act whether or not applicable effluent limitation guidelines have been promulgated or approved. Such permits shall contain a provision that, if an applicable standard limitation is promulgated under Section $301(b)(2)(C)$ and (D). $304(b)(2)$, and $307(a)(2)$ of the Clean Water Act and that effiuent standard or limitations is more stringent than any effluent limitation in the permit, or controls a pollutant not limited in the permit, the permit shall be promptly modified or revoked and reissued to conform to the effluent standard or limitation.

(2) The Department shall promptly modify or revoke and reissue any permit to incorporate an applicable effluent standard or limitation under Sections $301(\mathrm{~b})(2)(C)$ and (D), 304(b)(2) and 307 (a)(2) of the Clean Water Act which is promulgated or approved after the permit is issued if that effluent standard or limitation is more stringent than any effluent limitation in the permit, or controls a pollutant not limited in the permit.

(d) Water quality standards and State requirements: any requirements in addition to or more stringent than promulgated effluent limitations guidelines or standards under Sections 301, 304, 306, 307. 318, and 405 of the Clean Water. Act necessary to:

(1) Achieve water quality standards established under Section 303 of the Clean Water Act;

(2) Attain or maintain a specified water quality through water quality-related effluent limits established under Section 302 of the Clean Water Act;

(3) Conform to applicable water quality requirements under Section $401(a)(2)$ of the Clean Water Act when the discharge affects a state other than the certifying State:

(4) Incorporate any more stringent limitations, treatment standards, or schedule of compliance requirements established under Federal or State law or regulations in accordance with Section 301(b)(1)(C) of the Clean Water Act or Chapter 46-12 of the General Laws of Rhode Island;

(5) Ensure consistency with the requirements of a Water Quality Management plan approved by EPA and the Governor of Rhode Island under Section 208(b) of the Clean Water Act;

(6) Incorporate Section 403(c) criteria under 40 CFR Part 125. Subpart M, for ocean discharges:

(7) Incorporate alternative effluent limitations or standards where warranted by "fundamentally different factors," under 40 CFR Part 125, Subpart D.

(e) Toxic pollutants: limitations established under paragraphs (a), (b), or (d) of this section, to control pollutants meeting the criteria listed in paragraph $(e)(1)$ of this section, shall be established in accord- 
ance with paragraph (e)(2) of this section. An explanation of the development of these limitations shall be included in the fact sheet under Rule 39.

(1) Limitations must control all toxic pollutants which:

(i) The Department determines (based on information reported in a permit application under Rule 11 or in a notification under subsection 16.01 or on other information) are or may be discharged at a level greater than the level which can be achieved by the technology-based treatment requirements appropriate to the permittee under 40 CFR Section $125.3(\mathrm{c})$; or

(ii) The discharge does or may use or manufacture as an intermediate or final product or byproduct.

(2) The requirement that the limitations control the pollutants meeting the criteria of paragraph (e)(1) of this section will be satisfied by:

(i) Limitations on those pollutants: or

(ii) Limitations on other pollutants which, in the judgement of the Department, will provide treatment of the pollutants under paragraph (e) (1) of this section to the levels required by 40 CFR Section 125.3(c).

(f) Maximum Daily Discharge Limitations. The requirement that the permit contain a list of all pollutants for which a permittee must report violations of maximum daily discharge limitations. This list shall include any toxic pollutant or hazardous substance, or any pollutant specifically identified as the method to control a toxic pollutant or hazardous substance.

(g) Best Management Practices: Adopt best management practices to control or abate the discharge of pollutants when:

(1) Authorized under Section 304(e) of the Clean Water Act for the control of toxic pollutants and hazardous substances from ancillary activities:

(2) Numeric effuent limitations are infeasible, or

(3) The practices are reasonably necessary to achieve effluent limitations and standards or to carry out the purposes and intent of the State and Federal Acts.

(h) Notification Level: The requirement that the permit contain a "notification level" which may not exceed those levels provided in Rule 16.01(a) or the level which can be achieved by the technologybased treatment requirements appropriate to the permittee under 40 CFR Section 125.3(c).
16 - Conditions Applicable to Specific Types of Permits. The following conditions, in addition to those set forth in Rules 14 and 15, apply to all RIPDES permits within the categories specified below:

16.01 Existing manufacturing, commercial, mining, and silvicultural dischargers and research facilities. All existing manufacturing, commercial, mining, and silvicultural dischargers and research facilities must notify the Department as soon as they know or have reason to believe:

(a) That any activity has occurred or will occur which would result in the discharge of any toxic pollutant which is not limited in the permit, if that discharge will exceed the highest of the following "notification levels."

(1) One hundred micrograms per liter (100 ug/l);

(2) Two hundred micrograms per liter (200 ug/l) for acrolein and acrylonitrile; five hundred micrograms per liter $(500$ ug/l) for 2, -dinitrophenol and for 2-methyl -4,6- dinitrophenol, and one milligram per liter (1 mg/l) for antimony:

(3) Five (5) times the maximum concentration value reported for the pollutant on the permit application;

(4) The level established by the Department in accordance with Rule 17.

(b) That they have begun or expect to begin to use or manufacture as an intermediate or final product or byproduct any toxic pollutant which was not reported in the permit application.

16.02 POTWs.

(a) All POTWs must provide adequate notice to the Department of the following:

(1) Any new introduction of pollutants into the POTW from an indirect discharger which would be subject to Sections 301 or $\mathbf{3 0 6}$ of the Clean Water Act, if it were directly discharging those pollutants; and

(2) Any substantial change in the volume or character of pollutants being introduced into that POTW by a source introducing pollutants into the POTW at the time of issuance of the permit.

(3) For purposes of this paragraph, adequate notice shall include information in (i) the quality of and quantity effluent introduced into the POTW, add (ii) any anticipated impact of the change on the quantity or quality of effluent to be discharged from the POTW.

16.03 Grants to POTWs. Any conditions imposed in grants made by the Ad- ministrator to POTWs under Sections 201 and 204 of the Clean Water Act or by the Department which are reasonably necessary for the achievement of effluent limitations under Section 301 of the Clean Water Act or Chapter 46.12 of the Gener. al Laws of Rhode Island.

16.04 Pretreatment Requirements for POTW

(a) Identify, in terms of character and volume of pollutants, any significant indirect dischargers into the POTW subject to pretreatment standards under Section 307(b) of the Clean Water Act, 40 CFR Part 403, and the Rhode Island Pretreatment Regulations;

(b) Notify the Department in advance of the quality and quantity of all new introduction of pollutants into a facility and of any substantial change in the pollutants introduced into a facility by an exist. ing user of the facility, except for such introductions of nonindustrial pollutants as the Department may exempt from this notification requirement when ample capacity remains in the facility to accommodate new inflows. Such notifications shall estimate the effects of such changes on the effluents to be discharged from the facility:

(c) To establish an effective regulatory program, alone or in conjunction with the operators of sewage collection systems. that will assure compliance and monitor progress toward compliance by industrial users of the facilities with toxicity standards and pretreatment standards:

(d) As actual flows to the facility approach design flow or design loading limits, to submit to the Department for approval, a program which the permittee and the persons responsible for building and maintaining the contributory system shall pursue in order to prevent overload of the facilities:

(e) Submit a local program when required by and in accordance with 40 CFR Part 403 and the Rhode Island Pretreatment Regulations to assure compliance with pretreatment standards to the extent applicable under Section $307(b)$. The local program shall be incorporated into the permit as described in 40 CFR Part 403 and the Rhode Island Pretreatment Regulations. The program shall require all indirect dischargers to the POTW to comply with the reporting requirements of 40 CFR Part 403 and the Rhode Island Pretreatment Regulations. 
16.05 Privately Owned Treatment Works. A permit for a privately owned treatment works may contain any conditions expressly applicable to aniy user, as a limited co-permittee, that may be necessary in the permit issued to the treatment works to ensure compliance with applicable regulations parts. Alternatively, the Director may issue separate permits to the treatment works and to its users, or may require a separate permit application from any user. The Director's decision to issue a permit with no conditions applicable to any user, to impose conditions on one or more users, to issue separate permits, or to require separate applications, and the basis for that decision, shall be stated in the fact sheet for the draft permit for the treatment works.

16.06 Reissued Permits

(a) Except as provided in paragraph (b) of this subsection, when a permit is renewed or reissued, interim limitations, standards, or conditions which are at least as stringent as the final limitations, standards, or conditions in the previous permit (unless the circumstances on which the previous permit was based have materially and substantially changed since the time the permit was issued and would constitute cause for permit modification or revocation and reissuance) shall be included in such permit.

(b) When effluent limitations are imposed under Section 402(a)(1) of the Clean Water Act in a previously issued permit and these limitations are more stringent than the subsequently promulgated eftluent guidelines, this paragraph shall apply unless:

(1) The discharger has installed the treatment facilities required to meet the effluent limitations in the previous permit and has properly operated and maintained the facilities but has nevertheless been unable to achieve the previous limitations. In this case the limitations in the renewed or reissued permit may reflect the level of pollutant control actually achieved (but shall not be less stringent than required by the subsequently promulgated effluent limitation guidelines);

(2) The subsequently promulgated effluent guidelines are based on best conventional pollutant control technology (Section $301(b)(2)(E)$ of the Clean Water Act):

(3) The circumstances on which the previous permit was based have materially and substantially changed since the time the permit was issued and would constitute cause for permit modification or revocation and reissuance; or

(4) There is increased production at the facility which results in significant reduction in treatment efficiency, in which case the permit limitations will be adjusted to reflect any decreased efficiency resulting from increased production and raw waste loads; but in no event shall permit limitations be less stringent than those required by subsequently promulgated standards and limitations.

16.07 Coast Guard. When a permit is issued to a facility that may operate at certain times as a means of transportation over water, a condition that the discharge shall comply with any applicable regulations promulgated by the Secretary of the Department in which the Coast Guard is operating, that establish specifications for safe transportation, handling. carriage. and storage of pollutants.

16.08 Navigation. Any conditions that the Secretary of the Army considers necessary to ensure that navigation and anchorage will not be substantially impaired, in accordance with Rule 55.

16.09 Sewage Sludge. A permit may contain conditions governing the disposal of sewage sludge from publicly owned treatment works in accordance with Section $\mathbf{4 0 5}$ of the Clean Water Act and any applicable regulations.

17 - Calculating RIPDES permit conditions.

17.01 Outfalls and discharge points. All permit effluent limitations, standards, and prohibitions shall be established for each outfall or discharge point of the permitted facility, except as otherwise provided under Rule $15.01(\mathrm{~g})$ (BMPs where limitations are infeasible) and paragraph 17.09 of this section (limitations on internal waste streams).

17.02 Production-based limitations.

(a) In the case of POTWs, permit limitations, standards or prohibitions shall be calculated based on design flow.

(b) Except in the case of POTWs, calculation of any permit limitations, standards, or prohibitions which are based on production (or other measure of operation) shall be based not upon the design production capacity but rather upon a reasonable measure of actual production of the facility, such as the production during the high month of previous year, or the monthly average for the highest of the previous five years. For new sources actual production shall be estimated using projected production. The time period for calculating permit limitations, for example, monthly production, shall be used to calculate average monthly discharge limitations.

17.03 Metals. All permit effiuent limitations, standards, or prohibitions for a metal shall be expressed in terms of the total metal (that is, the sum of the dissolved and suspended fractions of the metal) unless:

(a) An applicable effluent standard or limitation has been promulgated under the Federal or State Acts and specified the limitation for the metal in the dissolved or valent forms; or

(b) In establishing permit limitations on a case-by-case basis under 40 CFR Section 125.3, it is necessary to express the limitation on the metal in dissolved or valent form in order to carry out the provisions of the State and Federal Acts.

17.04 Continuous discharges. For continuous discharges all permit effluent limitations, standards, and prohibitions, including those necessary to achieve water quality standards, shall unless impracticable be stated as:

(a) Maximum daily and average monthly discharge limitations for all dischargers other than publicly owned treatment works; and

(b) Maximum daily, average weekly and average monthly discharge limitations for POTWs.

17.05 Non-continuous discharges. Discharges which are not continuous shall be particularly described and limited, considering the following factors, as appropriate:

(a) Frequency (for example, a batch discharge shall not occur more than once every 3 weeks):

(b) Total mass (for example, not to exceed 100 pounds of zinc and 200 pounds of chromium per batch discharge):

(c) Maximum rate of discharge of pollutants during the discharge (for example, not to exceed 2 pounds of zinc per minute); and

(d) Prohibition or limitation of specified pollutants by mass, concentration, or other appropriate measure (for example, shall not contain at any time more than 0.1 $\mathrm{mg} / 1$ zinc or more than .25 pounds of zinc in any discharge). 
17.06 Mass limitations

(a). All pollutants limited in permits shall have limitations, standards, or prohibitions expressed in terms of mass except:

(l) For $\mathrm{pH}$, temperature, radiation, or other pollutants which cannot appropriately be expressed by mass:

(2) When applicable standards and limitations are expressed in terms of other units of measurement; or

(3) If in establishing permit limitations on a case-by-case basis under 40 CFR Section 125.3, limitations expressed in terms of mass are infeasible because the mass of the pollutant discharged cannot be related to a measure of operation (for example, discharges of TSS from certain mining operations), and permit conditions ensure that dilution will not be used as a substitute for treatment.

(b) Pollutants limited in terms of mass may additionally be limited in terms of other units of measurement, and the permit shall require the permittee to comply with both limitations.

17.07 Pollutants in intake water. Except as provided in Rule 17.08, effiuent limita. tions imposed in permits shall not be adjusted for pollutants in the intake water.

17.08 Net limitations.

(a) Upon request of the discharger, effluent limitations or standards imposed in a permit shall be calculated on a "net" basis; that is, adjusted to reflect credit for pollutants in the discharger's intake water. if the discharger demonstrates that its intake water is drawn from the same body of water into which the discharge is made and if:

(1) (i) The applicable effluent limitations and standards contained in 40 CFR Subchapter $\mathbf{N}$ specifically provide that they shall be applied on a net basis; or

(ii) The discharger demonstrates that pollutants present in the intake water will not be entirely removed by the treatment systems operated by the discharger; and

(2) The permit conditions requiring:

(i) The permittee to conduct additional monitoring (for example, for flow and concentration of pollutants) as necessary to determine continued eligibility for and compliance with any such adjustments; and

(ii) The permittee to notify the Department if eligibility for an adjustment under this section has been altered or no longer exists. In that case, the permit may be modified.

(b) Permit effluent limitations or stan dards adjusted under this paragraph shall be calculated on the basis of the amount of pollutants present after any treatment steps have been performed on the intake water by or for the discharger. Adjustments under this paragraph shall be given only to the extent that pollutants in the intake water which are limited in the permit are not removed by the treatment technology employed by the discharger.

(c) In addition, effluent limitations or standards shall not be adjusted to the extent that the pollutants in the intake water vary physically, chemically, or biologically from the pollutants limited in the permit. Nor shall effluent limitations or standards be adjusted to the extent that the discharger significantly increases concentrations of pollutants in the intake water, even though the total amount of pollutants might remain the same.

(d) This subsection shall apply to discharges to surface or ground water only if the discharger demonstrates to the satisfaction of the Department that the discharger is not responsible for the background pollutants present in the intake water.

17.09 Internal waste streams.

(a) When permit effiuent limitations or standards imposed at the point of discharge are impractical or infeasible, effluent limitations or standards for discharges of pollutants may be imposed on internal waste streams before mixing with other waste streams or cooling water streams. In those instances, the monitoring required by Rule 14.11(b) shall also be applied to the internal waste stream.

(b) Limits on internal waste streams will be imposed only when the fact sheet under Rule 39 sets forth the exceptional circumstances which make such limitations necessary, such as when the final discharge point is inaccessible (for example, under 10 meters of water), the wastes at the point of discharge are so diluted as to make monitoring impracticable, or the interferences among pollutants at the point of discharge would make detection or analysis impracticable.

17.10 Disposal of pollutants into wells, into POTWs, or by land application. Permit limitations and standards shall be calculated as provided in Rule 18.

17.11 Water quality based effluent limitations applicable to discharge into the surface waters of the State shall be developed in accordance with "Rhode Island Water Quality Regulations for Water Pollution Control" as amended. 17.12(a) The values assigned to the toxic substances listed in Appendix E shall be used in computing limitations of an individual toxic substance being discharged from a source into surface waters. The limitation derived through use of these values shall determine the permissible effluent concentration of an individual toxic substance provided that the effluent standard for toxic discharges, as set forth in $\mathbf{4 0}$ CFR Section 125.3, is not exceeded.

(b) In-stream concentrations of discharged pollutants shall be determined by the following formulas, or other methods which may be found to be acceptable.

(i) For effiuent discharges into surface waters of the State with essentially one dimensional flow (stream discharge):

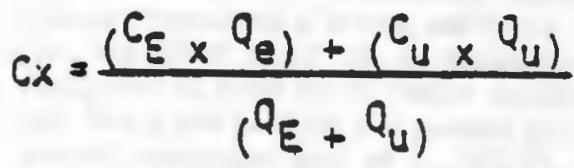

where. $\mathrm{Cx}=$ in-stream concentration of the pollutant, downstream of the discharge.

$C_{E}=$ concentration of the pollutant in the effluent.

$Q_{E}=$ effluent discharge flow rate.

$\mathrm{C}_{\mathrm{u}}=$ concentration of the pollutant in the receiving stream, immediately upstream of the discharge.

$Q_{u}=$ the seven day, 10 year, low flow of the receiving stream, immediately upstream of the discharge.

(ii) For effluent discharges into surface waters of the State with essentially multidimensional flow:

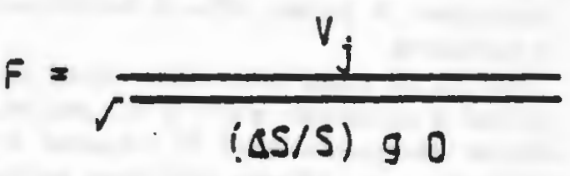

where, $F=$ Froude number

$\mathrm{Vj}=$ jet velocity (ft./sec.)

$\Delta S=$ difference in specific gravity between the waste and the surrounding seawater.

$\mathrm{S}=$ specific gravity of the waste

8 = acceleration due to gravity (ft. $/ \mathrm{sec}^{2}$ )

$\mathrm{D}=$ discharge jet diameter (ft.)

The initial dilution, $D_{1}$ is a function of the Froude number, $F$, the depth of the discharge port, $Y$, and the diameter of the discharge port, $d$. The dilution factor is determined using the curves shown in Appendix F. Figure 1 . 
Secondary dispersion of the effluent will be determined using Appendix F, Figure 2 where:

$D_{2}=$ dilution due to dispersion after initial dilution

$V=$ current velocity (ft./sec.)

(c) Where a total maximum daily load has been developed for a pollutant in a given stream segment, effiuent limitations for that pollutant shall be determined by calculating waste load allocations for individual discharges within that stream segment, instead of by the methods outlined in paragraphs (a) and (b) of this section.

18 - Calculating Adjusted RIPDES Permit Condition for Certain Practices.

(a) When part of a discharger's process wastewater is not being discharged into surface waters of the State or contiguous zone because it is disposed into a well, into a POTW, or by land application thereby reducing the flow or level of pollutants being discharged into surface waters of the State. applicable effluent standards and limitations for the discharge in a RIPDES permit shall be adjusted to reflect the reduced raw waste resulting from such disposal. Effluent limitations and standards in the permit shall be calculated by one of the following methods:

(1) If none of the waste from a particular process is discharged into surface waters of the State, and effluent limitations guidelines provide separate allocation for wastes from that process, all allocations for the process shall be eliminated from calculation of permit effluent limitations or standards.

(2) In all cases other than those described in paragraph (a)(1) of this section, effluent limitations shall be adjusted by multiplying the effluent limitation guidelines to the total waste stream by the amount of wastewater flow to be treated and discharged into surface waters of the State and dividing the result by the total wastewater flow. Effluent limitations and standards so calculated may be further adjusted under 40 CFR Part 125. Subpart D or applicable State regulations to make them more stringent if discharges to wells, POTWs or by land application change the character or treatability of the pollutants being discharged to receiving waters.

This method may be algebraically expressed as:

$P=E \times N / T$

where $\mathbf{P}$ is the permit effluent limitation, $E$ is the limitation derived by apply- ing effluent guidelines to the total waste stream, $\mathbf{N}$ is the wastewater flow to be treated and discharged to surface waters of the State, and $\mathrm{T}$ is the total wastewater flow.

(b) Paragraph (a) of this section shall not apply to the extent that promulgated effluent limitations guidelines:

(1) Control concentrations of pollutants discharged but not mass; or

(2) Specify a different specific technique for adjusting effluent limitations to account for well injection, land application, or disposal into POTWs.

(c) Paragraph (a) of this section does not alter a discharger's obligation to meet any more stringent requirements established under Rules 14, 15 and 16.

19 - Duration of Permit.

(a) A permit shall be effective for a fixed term not to exceed five (5) years.

(b) A permit may be issued for a full term if the permit includes effluent limitations and a compliance schedule to meet the requirements of Section $301(\mathrm{~b})(2)(A)$. (C). (D), (E), and (F) of the Clean Water Act. whether or not applicable effiuent limitations guidelines have been promulgated or approved.

(c) A determination that a particular discharger falls within a given industrial category for purposes of setting a permit expiration date under paragraph (b) of this section is not conclusive in that industrial category for any other purposes, and does not prejudice any rights to challenge or change that inclusion at the time that a permit based on that determination is formulated.

(d) The term of a permit shall not be extended by modification beyond the duration specified in subsection (a) above.

(e) The Director may issue any permit for a duration that is less than the full allowable term under this section.

20 - Schedule of compliance.

20.01 General. The permit may, when appropriate, specify a schedule of compliance leading to compliance with the State and Federal Acts and all other applicable authority for these regulations.

20.02 Time for compliance. Any schedules of compliance under this section shall require compliance as soon as possible.

(a) For discharges to surface water or groundwater. schedules of compliance shall require compliance not later than the applicable statutory deadline under State and Federal law, and shall be subject to State and Federal regulations. (b) The first RIPDES permit issued to a new source, a new discharger, which commenced discharge after August 13, 1979, or a recommencing discharger, may not contain a schedule of compliance under this section. Within the shortest feasible time of issuance of the new sources new dischargers recommencing discharge permit (not to exceed 90 days) the owner or operator must meet permit conditions.

20.03 Interim dates. Except as provided in paragraph (a)(2) of Rule 20.04, if a permittee establishes a schedule of compliance which exceeds one year from the date of permit issuance, the schedule shall set forth interim requirements and the dates for their achievernent.

(a) The time between interim dates shall not exceed one year.

(b) If the time necessary for completion of any interim requirement (such as the construction of a control facility) is more than one year and is not readily divisible into stages for completion, the permit shall specify interim dates for the submission of reports of progress toward completion of the interim requirements and indicate a projected completion date. Examples of interim requirements include: (1) submit a complete Step I construction grant (for POTWs): (2) get a contract for construc. tion of required facilities; (3) commence construction of required facilities; and (4) complete construction of required facilities.

(c) Reporting. The permit shall be written to require that no later than 14 days following each interim date and the final date of compliance, the permittee shall notify the Department in writing of its compliance or noncompliance with the interim or final requirements.

20.04 Alternative schedules of compliance. A RIPDES permit application or permittee may cease conducting activities regulated by the State Act rather than continue to operate and meet permit requirements as follows:

(a) If the permittee decides to cease conducting regulated activities at a given time within the term of a permit which has already been issued:

(1) The permit may be modified to contain a new or additional schedule leading to timely cessation of activities; or

(2) The permittee shall cease conducting permitted activities before noncom. pliance with any interim or final compliance schedule requirement already specified in the permit. 
(b) If the decision to cease conducting regulated activities is made before issuance of a permit whose term will include the termination date, the permit shall contain a schedule leading to termination which will ensure compliance no later than the statutory deadline in the Clean Water Act.

(c) If the permittee is undecided whether to cease conducting regulated activities. the Department may issue or modify a permit to contain two schedules as follows:

(1) Both schedules shall contain an identical interim deadline requiring a final decision on whether to cease conducting regulated activities no later than a date which ensures sufficient time to comply with applicable requirements in a timely manner if the decision is to continue conducting regulated activities;

(2) One schedule shall lead to timely compliance with applicable requirements and shall be no later than the statutory deadline in the Clean Water Act:

(3) The second schedule shall lead to cessation of regulated activities by a date which will ensure timely compliance with applicable requirements, and shall be no later than the statutory deadline in the Clean Water Act:

(4) Each permit containing two schedules shall include a requirement that after the permittee has made a final decision under paragraph (c)(1) of this section it shall follow the schedule leading to compliance if the decision is to continue conducting regulated activities, and follow the schedule leading to termination if the decision is to cease conducting regulated activities.

(d) The applicant's or permittee's decision to cease conducting regulated activities shall be evidenced by a solemn public commitment satisfactory to the Department, such as a resolution of the board of directors of a corporation.

20.05 A publicly owned treatment works (POTW) required to develop a pretreatment program shall have a pretreatment program compliance schedule incorporated into the RIPDES permit at the time of issuance, reissuance or modification of the permit. The compliance schedule shall require the development of an approvable POTW pretreatment program no later than the time prescribed by 40 CFR Part 403.8 and Rule 10 of the Rhode Island Pretreatment regulations, whichevor is more stringent.
20.06 New sources or new dischargers or sources which recommence discharging after terminating operations and those sources which had been indirect dischargers which commence discharging into surface waters of the State do not qualify for compliance schedules under this section.

20.07 All permittees shall provide a report indicating the status of compliance in accordance with Rule 14.

\section{1 - Effect of a Permit.}

(a) Except for any toxic effluent standards and prohibitions imposed under Section 307 of the Clean Water Act, compliance with a permit during its term constitutes compliance for purposes of enforcement under the Clean Water Act and Chapter $46-12$ of the General Laws of Rhode Island. A permit, however, may be modified, revoked and reissued, or terminated during its term for cause as set forth in these regulations.

(b) The issuance of a permit does not convey any property rights of any sort, or any exclusive privilege.

(c) The issuance of a permit does not authorize any injury to persons or property or invasion of other private rights, or any infringement of Federal. State or local law or regulations.

22 - Transfer of Permits.

(a) Transfers by modification. Except as provided in paragraph (b) of this section, a permit may be transferred by the permittee to a new owner or operator only if the permit has been modified or revoked and reissued or a minor modification made to identify the new permittee and incorporate such other requirements as may be necessary under the State and Federal Acts.

(b) Automatic transfers. As an alterna. tive to transfers under paragraph (a) of this section, any RIPDES permit may be automatically transferred to a new permittee if:

(1) The current permittee notifies the Department in writing by certified mail of the proposed transfer as follows:

(i) Where production leveis, products produced, rates of discharge, and wastewater characteristics will remain unchanged, the following information shall be submitted at least 90 days prior to a proposed "transfer date":

(A) Name and address of current facility;

(B) Name and address of new Owners;

(C) RIPDES permit number;
- (D) Names of the new principal persons responsible:

(E) Names of persons upon whom legal process can be served; and

(F) A notarized statement signed by the new principal officer stating that he has read the RIPDES permit and agrees to abide by all the conditions of the permit and that the production levels, products produced, rates of discharge, and wastewater characteristics will remain unchanged.

(ii) Where there will be a change in production levels, products produced, rates of discharge, or wastewater characteristics, the information required in paragraph (b)(I)(i) shall be submitted at least 180 days prior to a proposed transíer date.

(2) The current permittee shall include in the notice of proposed transfer a written agreement between the existing and new permittee which includes a specific date for transfer of permit responsibility, coverage. and liability between the parties.

(3) The Department does not notify the existing permittee and the proposed new permittee, within thirty (30) days of receipt of notice or proposed transfer, of an intent to modify, revoke or revoke and reissue the permit. A modification under this paragraph may also be a minor modification under Rule 25. If such notice is not received, the transfer is effective on the date specified in the agreement mentioned in paragraph (b)(2) of this section.

(4) Whenever the regulated discharge has ceased prior to the proposed permit transfer, any compliance schedule shall not be automatically reinstated but shall be subject to revision or complete withdrawal if circumstances leading to its imposition have been changed.

\section{3 - Modification or Revocation and}

\section{Reissuance of Permits.}

(a) When the Department receives any information (for example, inspects the facility, receives information submitted by the permittee as required in the permit. receives a request for modification or revocation and reissuance, or conducts a review of the permit file) a determination may be made by the Department as to whether cause exists including but not limited to causes as provided under paragraphs (b) and (c) of this section, for modification, or revocation and reissuance of the permit. If cause exists, the Department may modify, or revoke and reissue the permit accordingly, subject to the limi- 
tations of paragraph (c) of this section, a schedule of compliance in accordance and may request an updated application if with Rule $\mathbf{2 0}$ in order for the permittee to necessary. When a permit is modified, attain the new standards. If conditions of only the conditions subject to modification the permit are not contested, they shall go are reopened. If a permit is revoked and into effect notwithstanding the contesting reissued, the entire permit is reopened and of other conditions.

subject to revision. The permit may be reissued for a new term. If a permit modification satisfies the criteria in Rule 25 for "minor modifications" the permit may be modified without a draft permit or public review. Otherwise, a draft permit must be prepared and other procedural steps followed.

(b) The following are causes for modifcation, but not revocation and reissuance of permits except when the permittee requests or agrees:

(1) Alterations. There are material and substantial alterations or additions to the permitted facility, activity, or discharge which occurred after a permit issuance which justify the application of permit conditions that are different or absent in the existing permit.

(2) Information. The Department has received new information. Permits may be modified, or revoked and reissued during their terms for this cause only if the information (other than revised regulations, guidance, or test methods) was not available at the time of permit issuance and would have justified the application of different permit conditions at the time of issuance. For general permits, this cause shall include any information indicating that the cumulative effects on the environment are unacceptable.

(3) New regulations or judicial decision. A permit or any condition thereof may be modified, or revoked and reissued after promulgation of new or amended water quality standards, effluent limitation guidelines by EPA. or by judicial decision, as follows:

(i) If the permit or permit condition in question was based on a prior water qual. ity standard or effluent limitations guidelines which has been altered or revoled; or

(ii) If a court of competent jurisdiction has remanded and stayed the new standards or regulations,

the procedures provided by Rule 36 for modification, or revocation and reissuance may be initiated by the Department or by any interested person (including the permittee) within 90 days of the new guideline or judicial remand. If such modification or revocation and reissuance is ordered. the Department may provide for
(4) Compliance schedules. The Department determines good cause exists for modification of a compliance schedule, such as an act of God, strike, flood, or materials shortage or other events over which the permittee has little or no control and for which there is no reasonably avail. able remedy. However, in no case shall a RIPDES compliance schedule be modified to extend beyond an applicable statutory deadline. This does not preclude the Department from the revocation and reissuance of a compliance schedule for cause.

(5) The Department may also modify a permit:

(i) When the permittee has filed a timely request for a variance, or for "fundamentally different factors" under the Clean Water Act and the Department processes the request under the applicable provision of Rule 57.

(ii) When required to incorporate an applicable toxic effluent standard or prohibition under 307(a) of the Clean Water Act.

(iii) When required by the "reopener" conditions in a permit. which are established in the permit under Rule 15.01 (for toxic effluent limitations) or Rule 12 of the Rhode Island Pretreatment Regula. tions.

(iv) Upon request of a permittee who qualifies for effluent limitations on a net basis.

(v) When a discharger is no longer eligible for net limitations.

(vi) As necessary under 40 CFR Section $403.8(e)$ or Rule 10 of the Rhode Island Pretreatment Regulations (compliance schedule for development of pretreat. ment program).

(vii) Upon failure of the State to notify, as required by Section $402(b)(3)$ of the Clean Water Act, another state whose waters may be affected by a discharge from the State.

(viii) When the level of discharge of any pollutant which is not limited in the permit exceeds the level which can be achieved by the technology-based treatment requirements appropriate to the permittee under 40 CFR Section 125.3(c).

(ix) When the permittee begins or expects to begin to use or manufacture as an intermediate or final product or byproduct any toxic pollutant which was not reported in the permit application.

(x) To establish a "notification level" as provided in Rules 15.01 and 16.01 .

(xi) To modify a schedule of compliance to reflect the time lost during construction of an innovative or alternative facility, in the case of a POTW which has received a grant under Section 202(a)(3) of the Clean Water Act for $100 \%$ of the costs to modify or replace facilities constructed with a grant for innovative and alternative wastewater technology under Section 202(a)(2) of the Clean Water Act. In no case shall the compliance schedule be modified to extend beyond an applicable Clean Water Act statutory deadline for compliance.

(xii) To include a plan or compliance schedule for the disposal of septage or sludge in accordance with "Rhode Island Rules and Regulations Pertaining to the Disposal and Utilization of Wastewater Treatment Facility Sludge.

(c) Causes for modification, or revocation and reissuance. The following are causes to modify or revoke and reissue a permit:

(1) Cause exists for termination under Rule 24 and the Department determines that modification, or revocation and reissuance is appropriate.

(2) The Department has received notifcation of a proposed transfer of the permit. A permit also may be modified to reflect a transfer after the effective date of an automatic transfer but will not be revoked and reissued after the effective date of the transfer except upon the request of the new permittee.

24 - Termination of Permits.

(a) The following are causes for terminating a permit during its term, or for denying a permit renewal application:

(1) Noncompliance by the permittee with any condition of the permit:

(2) Failure to pay applicable fees;

(3) The permittee's failure in the application or during the issuance of an NPDES or RIPDES permit, a treatment works approval or Construct and Operate order to disclose fully all relevant facts, or the permittee's misrepresentation of any relevant facts at any time;

(4) A determination that the permitted activity endangers human health or the environment and can only be regulated to acceptable levels by permit modification or termination; 
(5) A change in any condition that requires either a temporary or a permanent reduction or elimination of any discharge controlled by the permit:

(6) The nonconformance of the discharge with any applicable facility, basin or areawide plans; or

(7) Inconsistency with any duly promulgated effluent limitation, permit, regulation, statute, or other applicable State or Federal law.

25 - Minor Modifications of Permits. Upon the consent of the permittee, the Department may modify a permit to make the corrections or allowances for changes in the permitted activity listed in this section, without following the procedures of Rule 36. Any permit modification not processed as a minor modification under this section shall be made for cause and with draft permit and public notice. Minor modifications may only:

(a) Correct typographical errors;

(b) Require more frequent monitoring or reporting by the permittee:

(c) Change an interim compliance date in a schedule of compliance, provided the new date is not more than 120 days after the date specified in the existing permit and does not interfere with attainment of the final compliance date requirement:

(d) Allow for a change in ownership or operational control of a facility where the Department determines that no other change in the permit is necessary, provided that a written agreement containing a specific date for transfer of permit responsibility, coverage, and liability between the current and new permittees has been submitted to the Department;

(e) Change the construction schedule for a discharger which is a new source. No such change shall affect a discharger's obligation to have all pollution control equipment installed and in operation prior to discharge;

(I) Delete a point source outfall when the discharge from that outfall is terminated and does not result in discharge of pollutants from other outfalls except in accordance with permit limits.

i6 - Noncomplinnce and Program Reporting by the Department. The Department shall prepare quarterly and annual reports as detailed below. Any reports required under this section shall be submitted to the Regional Administrator and to any facility listed in the report. (a) Quarterly reports. The Department shall prepare quarterly narrative reports for major facilities as follows:

(1) Format. The report shall use the following format:

(i) Provide separate lists of each type of discharge and subcategorize the permittee as non-POTWs. POTWs, and Federal permittees;

(ii) Alphabetize each list by permittee name. When two or more permittees have the same name, the lowest permit number shall be entered first:

(iii) For each entry on a list. include the following information in the following order:

(A) Name, location, and permit number of the noncomplying permittee.

(B) A brief description and date of each instance of noncompliance for that permittee. Instances of noncompliance may include one or more of the kinds set forth in paragraph $(a)(2)$ of this section. When a permittee has noncompliance of more than one kind, combine the information into a single entry for each such permittee.

(C) The date(s) and a brief description of the action(s) taken by the Department to ensure compliance.

(D) Status of the instance(s) of noncompliance with the date of the review of the status or the date of resolution.

(E) Any details which tend to explain or mitigate the instance(s) of noncompliance.

(2) Instances of noncompliance to be reported. Any instances of noncompliance within the following categories shall be reported in successive reports until the noncompliance is reported as resolved. Once compliance is reported as resolved, it need not appear in subsequent reports.

(i) Failure to complete construction elements. When the permittee has failed to complete, by the date specified in the permit, an element of a compliance schedule involving either planning for construction (for example, award of a contract, preliminary plans), or a construction step (for example, begin construction, attain operation level), and the permittee has not returned to compliance by accomplishing the required element of the schedule within 30 days from the date a compliance schedule report is due under the permit.

(ii) Modification of schedules of compliance. When a schedule of compliance in the permit has been modified under Rules 23 and 25 because of the permittee's noncompliance. (iii) Failure to complete or provide compliance schedule or monitoring reports. When the permittee has failed to complete or provide a report required in a permit compliance schedule (for example. progress report or notice of noncompliance or compliance) or a monitoring report, and the permittee has not submitted the complete report within 30 days from the date it is due under the permit for compliance schedules, or from the date specified in the permit for monitoring reports.

(iv) Deficient reports. When the required reports provided by the permittee are so deficient as to cause misunderstanding by the Department and thus impede the review of the status of compliance.

(v) Noncompliance with other permit requirements. Noncompliance shall be reported in the following circumstances:

(A) Whenever the permittee has violated a permit requirement (other than reported under paragraphs (a)(2)(i) or (ii) of this section), and has not returned to compliance within 45 days from the date reporting of noncompliance was due under the permit: or

(B) When the Department determines that a pattern of noncompliance exists for a major facility permittee over the most recent four consecutive reporting periods. This pattern of noncompliance is based on violations of monthly averages and $e x$ cludes parameters where there is continuous monitoring. This pattern includes any violation of the same requirement in two consecutive reporting periods, and any violation of one or more requirements in each of four consecutive reporting periods; or

(C) When the Department determines significant permit noncompliance or other significant event has occurred, such as a discharge of a toxic or hazardous substance.

(vi) All other. Statistical information shall be reported quarterly on all other instances of noncompliance by major facilities with permit requirements not otherwise reported under paragraph (a) of this section.

(b) Annual reports. the Department shall prepare an annual report as required in this paragraph and shall submit an annual report to EPA.

(1) Statistical reports shall be prepared by the Department on non-major permittees indicating the total number reviewed, the number of noncomplying non-major permittees, the number of enforcement ac- 
tions, and number of permit modifications extending compliance deadlines. The sta. tistical information shall be organized to follow the types of noncompliance listed in paragraph (a) of this section.

(2) A separate list of non-major discharges which are one or more years behind in construction phases of the compliance schedule shall also be prepared in alphabetical order by name and permit number.

(c) Schedule

(1) Quarterly Reports

(i) On the last working day of May, August, November, and February, the Department shall submit to the Regional Administrator information concerning noncompliance with permit requirements by major dischargers in the State in accordance with the schedule below.

(ii) The Department shall make noncompliance reports concerning all RIPDES permits available to the public in accordance with the schedule below.

Quarters Covered by Reports on Noncompliance by All Major Dischargers January, February, and March ... May 31

April, May, and June ........ Aug. 31

July, August, and September . . Nov. 30

October, November, and December ... Feb. 28

(2) For all annual reports. The period for annual reports shall be for the calen. dar year ending December 31, with reports completed and available to the public no more than 60 days later.

27 - Concentrated Animal Feeding Operations.

(a) Permit requirement. "Concentrated animal feeding operations" (as defined in Rule 3) are point sources subject to the RIPDES permit program.

(b) Case-by-case designation of concentrated animal feeding operations.

(1) The Department may designate any animal feeding operation as a concentrated animal feeding operation upon determining that it is a significant contributor of pollution to the waters of the State. In making this designation the Department shall consider the following factors:

(i) The size of the animal feeding operation and the amount of wastes reaching the waters of the State:

(ii) The location of the animal feeding operation relative to waters of the State: (iii) The means of conveyance of animal wastes and process wastewaters into waters of the State;

(iv) The slope, vegetation, rainfall, and other factors affecting the likelihood or frequency of discharge of animal wastes and process wastewaters into waters of the State; and

(v) Other relevant factors.

(2) No animal feeding operation with less than the numbers of animals set forth in Appendix B shall be designated as a concentrated animal feeding operation unless:

(i) Pollutants are discharged into waters of the State through a manmade ditch, flushing system, or other similar manmade device; or

(ii) Pollutants are discharged directly into waters of the State which originate outside of the facility and pass over. across, or through the facility or otherwise come into direct contact with the animals confined in the operation.

(3) A permit application shall not be required from a concentrated animal feeding operation designated under this paragraph until the Department has conducted an on-site inspection of the operation and determined that the operation should and could be regulated under the permit program.

28 - Concentrated Aquatic Animal Production Facilities.

(a) Permit requirements. "Concentrated aquatic animal production facilities" (as defined in Rule 3) are point sources subject to the RIPDES permit program.

(b) Case-by-case designation of concentrated aquatic animal production facilities.

(1) The Department may designate any warm or cold water aquatic animal production facility as a concentrated aquatic animal production facility upon determining that it is a significant contributor of pollution to waters of the State. In making this designation the Department shall consider the following factors:

(i) The location and quality of the receiving waters of the State:

(ii) The holding, feeding, and production capacities of the facility:

(iii) The quantity and nature of the pollutants reaching waters of the State: and

(iv) Other relevant factors.

(2) A permit application shall not be required from a concentrated aquatic ani- mal production facility designated under this paragraph until the Department has conducted an on-site inspection of the facility and has determined in accordance with the criteria in Appendix $C$ that the facility should and could be regulated under the permit program.

29 - Aquaculture Projects.

(a) Permit requirement. Discharges into "aquaculture projects" (as defined in Rule 3) are subject to the RIPDES permit pro gram in accordance with 40 CFR Part 125, Subpart B and Chapter 46-12 of the General Laws of Rhode Island.

30 - Silvicultural Activities.

(a) Permit requirements "Silvicultural point sources" (as defined in Rule 3) are point sources subject to RIPDES permit program.

\section{1 - Separate Storm Sewers.}

(a) Permit requirement. Separate storm sewers are point sources subject to the RIPDES permit program. Separate storm sewers may be permitted either individually or under a general permit. A RIPDES permit for discharges into waters of the State from a separate storm sewer covers all conveyances which are a part of that separate storm sewer system, even though there may be several owners or operators of these conveyances. However, discharges into separate storm sewers from point sources which are not part of the separate storm sewer systems may also require a permit.

(b) Permit Limitations.

(1) Except as provided in paragraph (b)(2) of this section, a conveyance or system of conveyances operated primarily for the purpose of collecting and conveying storm water runoff which is not located in an urbanized area ("urbanized areas" are those designated by the Bureau of the Census according to the criteria in 39 FR 15202) and has not been designated by the Department under subsection (c) is not considered a point source and is not subject to the provisions of this section.

(2) Conveyances which discharge process wastewater or storm water runoff contaminated by contact with wastes, raw materials, or pollutant-contaminated soil. from lands or facilities used for industrial or commercial activities, into waters of the State or into separate storm sewers are point sources that must obtain RIPDES permits but are not separate storm sewers. 
(3) Whether 2 system of conveyance is or is not a separate storm sewer for purposes of this section shall have no bearing on whether the system is eligible for funding under Title II of the Clean Water Act.

(c) Case-by-case designation of separate storm sewers. The Department may designate a storm sewer not located in an urbanized area as a separate storm sewer. This designation may be made to the extent allowed or required by EPA promulgated effluent guidelines for point sources in the separate storm sewer category or when:

(1) The Water Quality Management plan under Section 208 of the Clean Water Act contains requirements applicable to such point sources; or

(2) The Department determines that a storm sewer is a significant contributor of pollution to the waters of the State. In making this determination the Department shall consider the following factors:

(i) The location of the discharge with respect to waters of the State;

(ii) The size of the discharge:

(iii) The quantity and nature of the pollutants reaching waters of the State; and

(iv) Other relevant factors.

32 - General Permits

(a) Coverage. The Department may issue a general permit in accordance with the following:

(1) Area. The general permit shall be written to cover a category of discharges described in the permit under paragraph (a)(2) of this section, except those covered by individual permits, within a geographic area. The area shall correspond to existing geographic or political boundaries, such as:

(i) Designated planning areas under Sections 208 and 303 of the Clean Water Act;

(ii) Sewer districts or sewer authorities;

(iii) City, county, or state political boundaries:

(iv) State highway systems;

(v) Standard metropolitan statistical areas as defined by the Office of Management and Budget:

(vi) Urbanized areas as designated by the Bureau of Census according to criteria in 39 FR 15202 (May 1, 1974); or

(vii) Any other appropriate division or combination of boundaries.

(2) Sources. The general permit shall be written to-regulate, within the area de- scribed in paragraph (a)(1) of this section, either:

(i) Separate storm sewers; or

(ii) A category of point sources other than separate storm sewers if the sources all:

(A) Involve the same or substantially similar types of operations:

(B) Discharge the same type of wastes;

(C) Require the same efftuent limitations or operating conditions;

(D) Require the same or similar monitoring; and

(E) In the opinion of the Department, are more appropriately controlled under a general permit than under individual permits.

(b) Administration.

(1) In general. General permits may be issued, modified, revoked, and reissued, or terminated in accordance with applicable requirements of these regulations. General permits shall be subject to review by EPA in accordance with the Memorandum of Agreement and 40 CFR Section 123.44

(2) Notice of Coverage. At least 60 days prior to the commencement of discharge under the terms of the general permit, all persons who seek to be covered by the general permit shall notify the Department in writing and shall (i) identify the source of their discharge and (ii) state why they believe the discharge fits within the coverage of the permit. The notification may be in the form of a simple letter and should be addressed to the Chief, Division of Water Resources. Department of Environmental Management. 75 Davis Street, Providence, Rhode Island, 02908.

(3) Requiring an individual permit.

(i) The Department may require any person authorized by a general permit to apply for and obtain an individual RIPDES permit. Any interested person may petition the Department to take action under this subparagraph. Cases where an individual RIPDES permit may be required include the following:

(A) The discharge(s) is a significant contributor of pollution as determined by the factors set forth in Rule 3I;

(B) This discharger is not in compliance with the conditions of the general RIPDES permit;

(C) A change has occurred in the avail. ability of demonstrated technology or practices for the control or abatement of pollutants applicable to the point source;
(D) Effluent limitation guidelines are promulgated for point source covered by the general RIPDES permit:

(E) A Water Quality Management Plan containing requirements applicable to such point sources is approved; or

(F) The requirements of paragraph (a) of this section are not met.

(ii) The Department may require any owner or operator authorized by a general permit to apply for an individual RIPDES permit as provided in paragraph $(b)(3)(i)$ of this section, only if the owner or operator has been notified in writing that a permit application is required. This notice shall include a brief statement of the reasons for this decision, an application form, a statement setting a time for the owner or operator to file the application, and a statement that on the effective date of the individual RIPDES permit the general permit as it applies to the individual permittee shall automatically terminate. The Department may grant additional time upon request of the applicant.

(iii) Any owner or operator authorized by a general permit may request to be excluded from the coverage of the permit by applying for an individual permit. The owner or operator shall submit an application with reasons supporting the request to the Department no later than 90 days after public notice of the general permit. The request shall be granted by issuing of any individual permit if the reasons cited by the owner or operator are adequate to support the request.

(iv) When an individual RIPDES permit is issued to an owner or operator otherwise subject to a general RIPDES permit, the applicability of the general permit to the individual RIPDES permittee is automatically terminated on the effective date of the individual permit.

(v) A source excluded from a general permit solely because it already has an individual permit may request that the individual permit be revoked, and that it be covered by the general permit. Upon revocation of the individual permit, the general permit shall apply to the source.

33 - Criteria \& Standards for the Rhode Island Pollutant Discharge Elimination System.

(a) The criteria and standards for the imposition of technology-based treatment requirements in RIPDES permit shall be as set forth in 40 CFR Part 125, Subpart A. 
(b) The criteria for issuance of permit to aquaculture projects shall be as set forth in 40 CFR Part 125, Subpart B.

(c) The criteria for extending compliance dates for facilities installing innovative technology shall. be as set forth in $\mathbf{4 0}$ CFR Part 125, Subpart C.

(d) The criteria and standards for determining fundamentally different factors shall be as set forth in 40 CFR Part 125, Subpart D.

(e) The criteria for determining alternative effluent limitations for the thermal component of a discharge shall be as set forth in 40 CFR Part 125, Subpart H.

(f) The criteria applicable to cooling water intake structures shall be as set forth in 40 CFR Part 125, Subpart I.

(g) Criteria for Extending Compliance Dates.

Extensions of the 1977 deadline in Section $301(i)(1)$ and (2) of the Clean Water Act for compliance with certain treatment requirements may be granted as described in 40 CFR Part 125, Subpart J.

(h) The criteria and standards for best management practices for ancillary industrial activities shall be as set forth in $\mathbf{4 0}$ CFR Part 125, Subpart K.

(i) The criteria and standards for imposing conditions for the disposal of sewage sludge shall be as set forth in 40 CFR Part 125, Subpart L.

(j) The criteria and standards for attaining effiuent quality through the application of secondary treatment shall be as set forth in 40 CFR Part 133.

34 - Procedures for Isauing a RIPDES Permit. The permit issuance process involves the following seven major procedural stages:

(a) An application is made in proper form.

(b) The Department prepares a tentative decision to issue or deny a draft RIPDES permit. This decision shall be made available for public comment.

(c) Where the Department issucs a draft RIPDES permit after consideration of any comments received during the public comment period the Department shall issue a final permit.

(d) The permittee may request an adjudicatory hearing to contest the final determination of the Department to grant, deny, modify, suspend or revoke a permit. The Department shall determine whether a hearing shall be granted.

(e) DEM shall hold a hearing in accordance with these regulations and the De- partment's "Administrative Rules of Practice and Procedure."

(f) The Director shall make all final decisions concerning the permit.

(g) A request for permit modification. revocation, reissuance, or termination shall be made in accordance with the procedures applicable to permit issuance, except for minor modifications which shall be made in accordance with Rule 25.

35 - Application Review by the Department.

(a) Permit Application.

(1) Any person who requires a RIPDES permit shall complete, sign and submit to the Department an application in accordance with these regulations. Applications are not required for general permits.

(2) The Department shall not begin the processing of a permit until the applicant has fully complied with the application requirements for that permit.

(3) Permit applications must comply with signature and certification requirements of Rule 12.

(b) Completeness.

(1) Upon receipt of a RIPDES application the Department shall have 60 days to review the application for completeness. Upon completing the review, the Department shall notify the applicant in writing whether the application is complete. If the application is incomplete. the Department shall list the information necessary to make the application complete and shall specify in the notice of deficiency a date for submitting the necessary information. Where the Department has deemed an application to be deficient, the processing of the application will be suspended and the applicant given $\mathbf{3 0}$ days to correct said deficiencies to the satisfaction of the Department.

(2) If the applicant fails or refuses to correct said deficiencies within the 30 day time period, and if an extension has not been granted by the Department, the permit may be denied and any appropriate enforcement action may be taken under the applicable statutory provisions.

(3) After the application is completed. the Department may request additional information from an applicant but only when necessary to clarify, modify, or supplement previously submitted material. Requests for such additional information will not render an application incomplete, but if the applicant fails or refuses to submit such information, the permit may be denied and any appropriate enforcement action may be taken under the applicable statutory provision.

(c) The Department shall determine whether a site visit(s) and inspection are necessary requirements and part of the application in order to evaluate the discharge completely and accurately. If the Department decides that a site visit is necessary for any reason in conjunction with the processing of an application, the applicant shall be notified and a date shall be scheduled.

(d) Completed RIPDES applications shall be sent to the Regional Administrator by the Department prior to the public notice of a draft permit in accordance with the terms of the Memorandum of Agreement.

(e) Draft permits shall be sent to the Regional Administrator prior to public notice in accordance with the terms of the Memorandum of Agreement.

36 - Modification, Revocution and Reissuance, or Termination Procedures.

(a) Permits may be modified, revoked and reissued, or terminated either at the request of any interested person (including the permittee) or upon the Department's initiative. However, permits may usually only be modified, revoked and reissued, or terminated for the reasons specified in Rules 23 or 24. Other basis for modification may only be found when consistent with the State Act so long as not for causes less stringent than required by the Clean Water Act and implementing regulations. All requests shall be in writing and shall contain facts or reasons supporting the request.

(b) If the Department decides the request is not justified, the Department shall send the requester a brief written response giving a reason for the decision. Denials of requests for modification, revocation and reissuance, or termination are not subject to public notice, comment or hearings.

(c) (1) If the Department tentatively decides to modify or revoke and reissue a permit under Rule 23, a draft permit shall be prepared under Rule 37 incorporating the proposed changes. The Department may request additional information and, in the case of a modified permit, may require the submission of an updated permit application. In the case of revoled and reissued permits, the Department shall re. quire the submission of a new application.

(2) In a permit modification under this section, only those conditions to be modified shall be reopened when a new draft 
permit is prepared. All other aspects for the existing permit shall remain in affect for the duration of the unmodified permit. When a permit is revoked and reissued under this section. the entire permit is reopened as if the permit had expired and was being reissued. During any revocation and reissuance proceeding the permittee shall comply with all conditions of the existing permit until a new final permit is reissued.

(3) "Minor modifications" as defined in Rule 25 are not subject to the requirements of this section.

(d) If the Department tentatively decides to terminate a permit under Rule 24. a notice shall be issued of intent to terminate. A notice of intent to terminate is a type of draft permit which follows the same procedures as any draft permit prepared under Rule 37.

(e) All draft permits (including notices of intent to terminate) prepared under this section shall be based on the administrative record is defined in Rule $\mathbf{4 0 .}$

37 - Draft Permits.

(a) All draft permits shall be issued in accordance with this section.

(b) Once an application is complete the Department shall tentatively decide whether to prepare a draft permit, or deny the application.

(c) If the Department tentatively decides to deny a permit application, a notice of intent to deny shall be issued. Notice of intent to deny the permit application is a type of draft permit which follows the same procedures as any draft prepared under this section. If the Department's final decision is that the tentative decision to deny the permit application was incorrect. the notice of intent to deny shall be withdrawn and the Department shall proceed to prepare a draft permit under paragraph (e) of this section.

(d) If the Department tentatively decides to issue a general permit, the Department shall prepare a draft general permit under paragraph (e) of this section.

(e) If the Department decides to prepare a draft permit, the permit shall contain the following information:

(1) All conditions under 40 CFR 122.41-122.43.

(2) All conditions under Rules 14, 15 and 16.

(3) All monitoring requirements under Rules 14 and 15.

(4) All variances under Rules 56 through 59.
(5) All effluent limitations, standards prohibitions and conditions under 40 CFR and 122.44 and the Rhode Isiand Pretreatment Regulations.

(f) All draft permits prepared under this section shall be accompanied by a statement of basis or fact sheet and shall be based on the administrative record publicly noticed and made available for public comment. The Department shall give notice of opportunity for a public hearing. issue a final decision and respond to comments. For RIPDES permits, an appeal may be taken under Rule 49.

38 - Statement of Basis. The Department shall prepare a statement of basis for every draft permit for which a fact sheet under Rule 39 is not prepared. The statement of basis shall briefly deseribe the derivation of the conditions of the draft permit and the reasons for them or, in the case of notices of intent to deny or terminate, reasons supporting the tentative decision. The statement of basis shall be sent to the applicant and, on request, to any other person.

\section{9 - Fact Sheet.}

(a) A fact sheet shall be prepared for every draft permit for a major facility or activity, for every general permit (Rule 32), for every draft permit that incorporates a variance or requires an explanation, and for every draft permit which the Department finds is the subject of a widespread public interest or raises major issues. The fact sheet shall briefly set forth the principal facts and the significant factual, legal, methodological and policy questions considered in preparing the draft permit. The Department shall send this fact sheet to the applicant and, on request. to any other person.

(b) The fact sheet shall include, when applicable:

(1) A brief description of the type of facility or activity which is the subject of the draft permit.

(2) The type and quantity of wastes, fuids, or pollutants which are proposed to be or are being treated, stored, disposed of, injected, emitted, or discharged.

(3) A brief summary of the basis for the draft permit conditions including references to applicable statutory or regulatory provisions and appropriate supporting references to the administrative record required by Rule 40 .

(4) Reasons why any requested variances or alternatives to required standards do or do not appear justified.
(5) A description of the procedures for reaching a final decision on the draft permit including:

(i) The beginning and ending dates of the comment period under Rule 41 and the address where comments will be received;

(ii) Procedures for requesting a hearing and the nature of that hearing: and

(iii) Any other procedures by which the public may participate in the final decision.

(6) Name and telephone number of a person to contact for additional information.

(7) Any calculations or other necessary explanation of the derivation of specific effluent limitations and conditions, includ. ing a citation to the applicable effluent limitation guideline or performance standard provisions as required under Rule 16 and reasons why they are applicable or an explanation of how the alternate effluent limitations were developed.

(8) When the draft permit contains any of the following conditions, an explanation of the reasons why such conditions are. applicable:

(i) Limitations to control toxic pollutants:

(ii) Limitations on internal wastestreams; or.

(iii) Limitations on indicator pollutants under 40 CFR Section 125.3(g).

(9) A sketch or detailed description of the location of the discharge(s) described in the application.

(10) For every permit to be issued to a treatment works owned by a person other than a state or municipality, an explana tion of the Director's decision on regulation of users under Rule 16.05.

40 - Administrative Record for the Draft Permits.

(a) The provisions of a draft permit shall be based on the administrative record defined in this section.

(b) For preparing a draft permit under Rule 37, the record shall consist of:

(1) The application, if required, and any supporting data furnished by the applicant:

(2) The draft permit or notice of intent to deny the application or to terminate the permit;

(3) The statement of basis or fact sheet;

(4) All documents cited in the statement of basis or fact sheet; and

(5) Other documents contained in the supporting file for the draft permit. 
(c) Material that is readily available in the offices of the Department, or published material that is generally available, and that is included in the administrative record under paragraphs (a) and (b) of this section, need not be physically included with the rest of the record as long as it is specifically referred to in the statement of basis or the fact sheet.

41 - Public Notice of Permit Actions and Public Period.

(a) Scope.

(1) The Department shall give public notice that the following actions have occurred:

(i) A permit application has been tentatively denied;

(ii) A draft permit (including a notice of intent to terminate a permit and a tentative decision to modify or revoke and reissue a permit) has been prepared;

(iii) $\mathbf{A}$ hearing has been scheduled under Rule 43; and

(2) No public notice is required when a request for permit modification, revocations and reissuance or termination is denied under Rule 36. Written notice of that denial shall be given to the requester and to the permittee.

(3) Public notices may describe more than one type of discharge, or permit action.

(b) Timing.

(1) Public notice of the preparation of a draft permit (including a notice of intent to deny a permit application) required under paragraph (a) of this section shall allow at least $\mathbf{3 0}$ days for public comment.

(2) Public notice of a public hearing shall be given at least 30 days before the hearing. (Public notice of the hearing may be given at the same time as public notice of the draft permit and the two notices may be combined.)

(c) Methods. Public notice of activities described in paragraph (a)(1) of this section shall be given by the following methods:

(1) By mailing a copy of a notice to the following persons (any person otherwise entitled to receive notice under this paragraph may waive his or her rights to receive notice for any classes and categories of permits):

(i) The applicant:

(ii) Any other agency which the Department knows has issued or is required to issue an environmental permit for the same facility or activity (including EPA): (iii) Federal and State agencies with jurisdiction over fish, shellfish, and wildlife resources and over coastal zone management plans, the Advisory Council on Historic Preservation. State Historic Preservation Officers, and other appropriate guvernment authorities, including any affected states;

(iv) Any State agency responsible for plan development under Sections $208(b)(2), 208(b)(4)$ or $303(e)$ of the Clean Water Act and the U.S. Army Corps of Engineers, the U.S. Fish and Wildlife Service and the National Marine Fisheries Service;

(v) Any user identified in the permit application of a privately owned treatment works;

(vi) The affected mayor, municipal clerk, planning board, sewerage authority, health officer, and environmental commission: by:

(vii) Persons on a mailing list developed

(A) Including those who request in writing to be on the list:

(B) Soliciting persons for "area lists" from participants in past permit proceed. ings in that area; and

(C) Notifying the public of the opportunity to be put on the mailing list through periodic publication in the public press and in such publications as State funded newsletters, environmental bulletins, or State law journals. (The Department may update the mailing list from time to time by requesting written indication of continued interest from those listed. The Department may delete from the list the name of. any person who fails to respond to such a request.)

(2) For major permits and general permits, publication of a notice in a daily or weekly newspaper within the area affected by the facility or activity:

(3) Such notice shall be published in any manner constituting legal notice to the public under State law for all other actions described in Rule 41(a)(1); and

(4) Any other method reasonable calculated to give actual notice of the action in question to the persons potentially affected by it, including press releases or any other forum or medium to elicit public participation.

(d) Contents.

(1) All public notices issued under this Rule shall contain the following minimum information: (i) Name and address of the office processing the permit action for which notice is being given:

(ii) Name and address of the permittce or permit applicant and, if different, of the facility or activity regulated by the permit, except in the case of draft general permit;

(iii) A brief description of the business conducted at the facility or activity described in the permit application or draft permit;

(iv) Name, address and telephone number of a person from whom interested persons may obtain further information, including copies of the draft permit or draft general permit, as the case may be, statement of basis or fact sheet, and the application;

(v) A brief description of the comment procedures required by Rules 42 and 43 and the time and place of any hearing that will be held, including a statement of procedures to request a hearing (unless a hearing has already been scheduled) and other procedures by which the public may participate in the final permit decision;

(vi) The location of the administrative record required by Rule 40 , the times at which the record will be open for public inspection, and a statement that all data submitted by the applicant is available as part of the administrative record;

(vii) A general description of the location of each existing or proposed discharge point and the name of the receiving water. For draft general permits, this requirement will be satisfied by a map or description of the permit area:

(viii) Any additional information considered necessary or proper; and

(ix) Where a request under Section 316(a) of the Clean Water Act has been filed under Rule 59. the public notice shall include:

(A) A statement that the thermal component of the discharge is subject to effluent limitations under Section 301 and 306 of the Clean Water Act and a brief description, including a quantitative statement, of the thermal effiuent limitations proposed under Section 301 or 306 of the Clean Water Act;

(B) A statement that a Section 316(a) request has been filed and that alternative less stringent effluent limitations may be imposed on the thermal component of the discharge under Section 316(a) and a brief description, including a quantitative statement, of the alternative effluent limitations, if any, included in the request: and 
(C) If the applicant has filed an early screening request pursuant to $40 \mathrm{CFR}$ Section 125.72 for a Section 316(a) variance. a statement that the applicant bas submitted such information.

(2) Public notices for hearings. In addition to the general public notice described in paragraph (d)(1) of this section, the public notice of a hearing under Rule 43 shall contain the following information:

(i) Reference to the date of previous public notice relating to the permit;

(ii) Date, time and place of the hearing; and

(iii) A brief description of the nature and purpose of the hearing, including the applicable rules and procedures.

(c) In addition to the general public notice described in paragraph (d)(1) of this section, all persons identified in para. graphs (c)(l)(i). (ii), (iii), (iv), and (v) of this section shall be mailed a copy of the fact sheet or statement of basis, the permit application (if any), and the draft permit (if any).

\section{2 - Public Comments and Requests} for Public Hearings.

During the public comment period provided under Rule 41, any interested party may submit written comments on the draft permit and may request a public hearing if no hearing has already been scheduled. A request for a public hearing shall be in writing and shall state the nature of the issues proposed to be raised in the hearing. All comments shall be considered in making the final decision and shall be answered as provided in Rule 48.

\section{3 - Public Hearings.}

Whenever the Department finds, on the basis of requests, a significant degree of public interest in a draft permit, the Department shall hold a public hearing. The Department also may hold a public hearing at its discretion, whenever, for instance, such a hearing might clarify one or more issues involved in the permit. Public notice of the hearing shall be given as specified in Rule 41.

Whenever a public hearing will be held, the Department shall designate a hearing officer for the hearing who shall be responsible for its scheduling and orderly conduct.

Any person may submit oral or written statements and data concerning the draft permit. Reasonable limits may be set upon the time allowed for oral statements, and the submission of statements in writing may be required. The public comment period under Rule 41 shall automatically be extended to the close of any public hearing under this section. The hearing officer may also extend the comment period by so stating at the hearing.

A tape recording or written transcript of the hearing shall be made available to the public.

44 - Obligation To Raise Issues and Provide Information During the Public Comment Period.

All persons, including applicants, who believe any condition of a draft permit is inappropriate or that the Department's tentative decision to deny an application. terminate a permit, or prepare a draft permit is inappropriate, must raise all reasonable ascertainable issues and submit all reasonably available arguments and factual grounds supporting their position, including all supporting material, by the close of the public comment period (including any public hearing) under Rule 41. All supporting materials shall be included in full and may not be incorporated by reference, unless they are already part of the administrative record in the same proceeding, or consist of State or Federal statutes and regulations, EPA documents of general applicability, or other generally available reference materials. Commenters shall make supporting material not already included in the administrative record available at the request of the Department. (A comment period longer than 30 days will often be necessary in complicated proceedings to give commenters a reasonable opportunity to comply with the requirements of this section. Commenters may request longer comment periods and these should be freely established under Rule 41 to the extent they appear necessary.) *

45 - Recpening of the Public Comment Period.

(a) If any data, information or arguments submitted during the public comment period, including information or arguments required under Rule 44, appear to raise substantial new questions concerning a permit, the Department may take one or more of the following actions:

(1) Prepare a new draft permit appropriately modified under Rule 36;

(2) Prepare a revised statement of basis under Rule 38, a fact sheet or revised fact sheet under Rule 39 and reopen the comment period; or
(3) Reopen or extend the comment period under Rule 41 to give interested persons an opportunity to comment on the information or arguments submitted.

(b) Comments filed during the reopened comment period shall be limited to the substantial new questions that caused its reopening. The public notice under Rule 41 shall define the scope of the reopening.

(b) Public notice of any of the above actions shall be issued under Rule 41 .

46 - Issuance and Effective Date of Permit.

(a) After the close of the public comment period under Rule 41 on a draft permit, the Department shall issue a final permit. The Department shall notify the applicant and each person who has submitted written comments or requested notice of the final permit decision. This notice shall include reference to the procedures for contesting a decision on a permit. For the purposes of this section, a final permit decision means a final decision to issue, deny, modify, revoke and reissue, or terminate a permit.

(b) A final permit decision shall become effective 30 days after the service of notice of the decision under paragraph (a) of this section, unless:

(1) A later effective date is specified in the decision; or

(2) An adjudicatory hearing is requested under Rule 49; or

(3) No comments requested a change in the draft permit, in which case the final permit shall become effective immediately upon issuance.

47 - Reaponse to Comments.

(a) At the time that any final permit is issued, pursuant to Rule 46 , the Department shall issue a response to comments. This response shall:

(1) Specify which provisions, if any, of the draft permit have been changed in the final permit decision, and the reasons for the change; and

(2) Briefly describe and respond to all significant comments on the draft permit or raised during the public comment period, or during any hearing.

(b) The response to comments shall be available to the public.

48 - Administrative Record for Final Permit.

(a) The Department shall base final draft permit and final permit decisions under Rule $\mathbf{4 6}$ on the administrative record defined in this section. 
(b) The administrative record for any final draft permit and final permit shall consist of the administrative record for the draft and:

(1) All comments received during the public comment period provided under Rule 41 (including any extension or reopening under Rule 45):

(2) The tape or transcript of any hearing(s) held under Rule 43;

(3) Any written materials submitted at such a hearing:

(4) The response to comments required by Rule 47 and any new material placed in the record under that section:

(5) Other documents contained in the supporting file for the permit; and

(6) The final permit.

(c) The additional documents required under paragraph (b) of this section should be added to the record as soon as possible after this receipt or publication by the Department. The record shall be complete on the date the final draft permit or final permit is issued.

(d) Material readily available at the issuing Department office, or published materials which are generally available and which are included in the administrative record under the standards of this section or of Rule 47 ("Response to Comments"), need not be physically included in the same file as the rest of the record as long as it is specifically referred to in the statement of basis or fact sheet or in the response to comments.

49 - Requests for an Adjudicatory Hearing

(a) Within 30 calendar days following the service of notice of the Department's issuance of a final draft permit or final - permit (where a final draft permit does not precede the final permit) under Rule 46 , any interested person may submit a request to the Department under paragraph (b) of this Rule for an adjudicatory hearing to reconsider or contest the conditions of that permit. If such a request is submitted by a person other than the permittee. that person shall simultaneously serve a copy of the request on the permittee.

(b) Such requests shall state each legal or factual question alleged to be at issue. and their relevance to the permit decision. together with a designation of the specific factual areas to be adjudicated and the hearing time estimated to be necessary for that adjudication. Information supporting the request or other written documents relied upon to support the request shall be submitted unless it is already in the administrative record.

(c) Such request shall also contain:

(1) The name, mailing address or telephone number of the person making such requests;

(2) A clear and concise factual statement of the nature and scope of the interest of the requester;

(3) The names and addresses of the persons who the requester represents; and

(4) A statement by the requester that, upon motion of any part, or upon order of the Administrative Hearing Officer or Officer's own motion and without cost or expense to any other party, the requester shall make available to appear and testify, the following:

(i) The requester;

(ii) All persons represented by the requester; and

(iii) All officers, directors, employees, consultants and agents of the requester and the persons represented by the requester.

(5) Specific references to the contested permit conditions, as well as suggested revised or alternative permit conditions (including permit denial) which, in the judgment of the requester, would be required to implement the purposes and policies of the State and Federal Acts.

(6) In the case of challenges to the application of control or treatment technologies identified in the statement of basis or fact sheet, identification of the basis for the objection, and the alternative technologies or combination of technologies which the requester believes are necessary to meet the requirements of the State and Federal Acts.

(7) Identification of the permit obligations that are contested or are inseparable from contested conditions and should be stayed if the request is granted by reference to the particular contested conditions warranting the stay.

(d) If the Department grants an adjudicatory hearing in whole or in part, the Department shall identify the permit conditions which have been contested by the requester and for which the adjudicatory hearing has been granted. Permit conditions which are not contested or for which the Department has denied the hearing request shall not be affected by, or considered at, the adjudicatory hearing and the Department shall specify these conditions in writing. (e) The Department must grant or deny all requests for an adjudicatory hearing on a particular permit. All requests that are granted for a particular permit shall be combined in a single adjudicatory hearing.

(f) The Department may extend the time allowed for submitting hearing requests under this section for good cause.

\section{0 - Stays of Contested Permit}

\section{Conditions}

(a) If a request for an adjudicatory hearing of a permit under Rule 49 is granted, an appeal from any effluent limitation, water quality standard or other applicable standard shall not automatically result in staying the conditions challenged. During the duration of such an appeal, the contested condition shall remain in full force and effect unless a stay is granted by the Chief of the Division of Water Resources on formal application by the permittee. In exercising his/her discretion on such stay requests the Chief shall consider the following factors:

(I) Pollution source and impacted ecosystem(s);

(2) Technological impediments to either immediate or phased-in compliance; or

(3) Economic impact of immediate or phased-in compliance including the benefits of capital purchases and employment increases required for such compliance.

(b) Where the Chief determines that immediate compliance would result in irreparable economic dislocation, while not required to preserve irreplaceable environmental resources, he/she shall direct that compliance with the effluent limitation, water quality standard or other applicable standard be phased into effect, partially stayed or entirely stayed pending resolution of the permittee's appeal.

(c) Any facility or activity holding an existing permit must:

(1) Comply, at minimum, with the conditions of that permit during any modification or revocation and reissuance proceeding under Rule 36; and

(2) To the extent conditions of any new permit are stayed under this section, comply with the conditions of the existing permit which correspond to the stayed conditions, unless compliance with the existing conditions would be technologically incompatible with compliance with other conditions of the new permit which have not been stayed, as determined by the Director in accordance with paragraphs (a) and (b) above. 
(d) If a request for an adjudicatory hearing of a permit regarding the initial permit issued for a new source, a new discharger, or a recommencing discharger is granted under Rule 49, the applicant shall be without a permit pending final departmental action. Wherever a source subject to this paragraph has received a final permit which is the subject of a hearing request, the Administrative Hearing Officer, on motion by the source, may issue a temporary order authorizing it to begin operation before final departmental action if it complies with all conditions of that final permit during the period until final departmental action. The Administrative Hearing Officer may grant such a motion in any case where:

(1) No party opposes it; or

(2) If a party opposes the motion but the source demonstrates that: (i) it is likely to prevail on the merits; (ii) irreparable harm to the environment will not result pending final agency action if it is allowed to commence operations before final agency action; and (iii) the public interest requires that the source be allowed to commence operations. All the conditions of any permit covered by that order shall be fully effective and enforceable.

51 - Decision on Request for Hearing

(a) Following the expiration of the time allowed by Rule 49 for submitting a request for an adjudicatory hearing, the Department shall decide the extent to which the request shall be granted. The Department shall grant a request either in whole or in part ordinarily only when the request conforms to the requirements of Rule 49 and sets forth material issues of fact relevant to the issuance of the permit.

(b) If the Department grants a request for an adjudicatory hearing, the Department shall identify those contested permit conditions for which an adjudicatory hearing has been granted and whether such conditions are stayed. The Department shall specify these conditions in writing and serve notice in accordance with Rule 52. Permit conditions which are not contested or for which the Department has denied the hearing request shall not be affected by or considered at the adjudicatory hearing.

(c) If the Department grants a request for an adjudicatory hearing, in whole or in part, in regard to a particular proposed permit, then any other request for an adju- dicatory hearing in regard to that permit shail be treated as a request to be a party and the Department shall grant any such request which meets the requirements of paragraph (a) of this section.

(d) If a reqeust for a hearing is denied in whole or part, the Department shall briefly state the reasons. Such denial shall be considered the final action of the Deoartment.

52 - Notice of Hearing. Public notice of the grant of an adjudicatory hearing regarding a permit shall be given by mailing a copy to all persons who commented on the draft permit, testified at the public hearing. or submitted a request for a hearing.

53 - Conduct of Adjudicatory Hearing. Adjudicatory hearings on permit conditions (including denial of variance requests) shall be governed by procedures described in "Administrative Rules of Practice and Procedure for the Department of Environmental Management" and in accordance with the Rhode Island Administrative Procedures Act.

54 - Individual Permits Required on a Case-by-Case Basis. Whenever the Department decides that an individual permit should be required for certain Concentrated Animal Feeding Operations (Rule 27), Concentrated Aquatic Animal Production Facilities (Rule 28), Separate Storm Sewers (Rule 31 ) and certain other facilities covered by a General Permit (Rule 32). the Department shall notify the discharger in writing of the reasons for that decision and shall include an application form in such notice. The discharger shall apply for a permit within 60 days of such notice. The question whether the initial designation was proper will remain open for consideration during the public comment period and in any subsequent hearing.

55-Conditions Requested by the Corps of Engineers and Other Governmental Agencies Concerning RIPDES Permits.

(a) If during the comment period for a draft RIPDES permit, the District Engineer advises the Department in writing that anchorage and navigation of any of the waters of the United States would be substantially impaired by the granting of a point source surface water discharge permit, the permit shall be denied and the applicant so notified.

If the District Engineer advised the Department that imposing specified conditions upon the permit is necessary to avoid any substantial impairment of anchorage or navigation, then the Department shall include the specified conditions in the permit. Review of appeal of a denial of a permit or of conditions specified by the District Engineer shall be made.through the applicable procedures of the Corps of Engineers, any may not be made through the procedures provided in these regula. tions. If the conditions are stayed by a court of competent jurisdiction or by applicable procedures of the Corps of Engineers, those conditions shall be considered stayed in the permit for the duration of that stay.

(b) If during the comment period, the U.S. Fish and Wildlife Service, the National Marine Fisheries Service, or any other State or Federal Agency, with jurisdiction over fish, wildlife, or public health advises the Department in writing that the imposition of specified conditions upon the permit is necessary to avoid substantial impairment of fish, shellfish, or wildlife resources, the Department may include the specified conditions in the permit to the extent they are determined necessary to carry out provisions of 40 CFR 122.12 and the State and Federal Acts.

(c) In appropriate cases the Department may consult with one or more of the agencies referred to in this section before issuing a draft permit and may reffect their views in the statement of basis, the fact sheet, or the draft permit.

(d) When affected states make recommendations to draft permits, the Department shall either accept such recommendations or submit a response to the affected states describing in detail the Department's reasons for not accepting the recommendations.

56-Variances Under the State and Federal Acts. An applicant for a renewal of a RIPDES may apply for the following variances:

(a) Variance requests by non-POTWs. A discharger which is not a publicly owned treatment works (POTW) may request a variance from otherwise applicable effluent limitations under any of the following statutory or regulatory provisions within the times specified in this paragraph:

(1) Fundamentally different factors. A request for a variance based on the presence of "fundamentally different factors" from those on which the effluent limitations guideline was based shall be made by 
the close of the public comment period under Rule 41 . The request shall explain how the requirements of Rule 44 and 40 CFR Part 125, Subpart D have been met.

(2) Non-conventional pollutants. A request for a variance from the BAT requirements for the Clean Water Act Section $301(b)(2)(F)$ pollutants (commonly called "non-conventional" pollutants) pursuant to Section 301 (c) of the Clean Water Act because of the economic capability of the owner or operator. or pursuant to Section $301(\mathrm{~g})$ of the Clean Water Act because certain environmental considerations, when those requirements were based on effluent limitation guidelines, must be made by:

(i) Submitting an initial request to the Regional Administrator, as well as to the Department, stating the name of discharg$e r$, the permit number, the outfall number(s), the applicable effluent guideline. and whether the discharger is requesting a Section 301 (c) or Section 301 (8) modification or both. This request must have been filed not later than:

(A) September 25, 1978, for a pollutant which is controlled by a BAT effluent limitation guideline, promulgated before December 27, 1977; or

(B) 270 days after promulgation of an applicable effluent limitation guideline for guidelines promulgated after December 27. 1977; and

(ii) Submitting a completed request no later than the close of the public comment period under Rule 41 demonstrating that the requirements of Rule 44 and the applicable requirements of Part 125 have been met.

(iii) Requests for variance from effluent limitations not based on effluent limitation guidelines, need only comply with para. graph (a)(2)(ii) of this section and need not be preceded by an initial request under paragraph (a)(2)(i) of this section.

(3) Delay in construction of POTW. An extension under the Clean Water Act Section $301(i)(2)$ of the statutory deadlines in Sections $301(\mathrm{~b})(1)(A)$ or $(b)(1)(C)$ of the Clean Water Act based on delay in completion of a POTW into which the source is to discharge must have been requested on or before June 26,1978 , or 180 days after the relevant POTW requested an extension under paragraph (b)(2) of this section, whichever is later. but in no event may this date have been later than December 25,1978 . The request shall explain how the requirements of 40 CFR Part 125. Subpart J have been met.

(4) Innovative technology. An extension under the Clean Water Act Section $301(k)$ from the statutory deadline of Section $301(b)(2)(A)$ for best available technology based on the use of innovative technology may be required no later than the close of the public comment period under Rule 41 for the discharger's initial permit requiring compliance with Section $301(b)(2)(A)$. The request shall demonstrate that the requirements of Rule 44 and Part 125. Subpart $C$ have been met.

(5) Water quality related effiuent limitations. A modification under Section 302(b)(2) of requirements under Section 302(a) pursuant to the Clean Water Act for achieving water quality related effiuent limitations may be requested no later than the close of the public comment under Rule 41 on the permit from which the modification is sought.

(6) Thermal discharges. A variance under the Clean Water Act Section 316(a) for the thermal component of any discharge must be filed with a timely application for a permit under this section, except that if thermal effluent limitations are established under the Clean Water Act Section $402(a)(1)$ or are based on water quality standards the request for a variance may be filed by the close of the public comment period under Rule 41. A copy of the request as required under 40 CFR Part 125. Subpart H, shall be sent simultaneously to the Department as required under 40 CFR Part 125.

(b) Variance requests by POTWs. A discharger which is a publicly owned treatment works (POTWs) may request a variance from otherwise applicable effluent limitations under any of the following statutory provisions as specified in this paragraph:

(i) Dischargers into marine waters. A preliminary request for a modification under the Clean Water Act Section 301(h) of requirements of the Clean Water Act Section $301(b)(1)(B)$ for dischargers into marine waters must have been submitted to the EPA no later than December 29. 1982. A final request must be submitted in accordance with the filing requirements of 40 CFR Part 125, Subpart G, and shall demonstrate that all the requirements of 40 CFR Part 125, Subpart $G$ have been met.
(2) Delay in construction. An extension under the Clean Water Act Section $301(i)(1)$ of the statutory deadlines in the Clean Water Act Sections $301(\mathrm{~b})(1)(B)$ or $(b)(1)(C)$ based on delay in the construction of the POTW must have been requested on or before June $26,1978$.

(3) Water quality based effluent limitation. A modification under the Clean Water Act Section 302(b)(2) of the requirements under Section 302(a) for achieving water quality based effluent limitations shall be requested no later than the close of the public comment period under Rule 41 on the permit from which the modification is sought.

(c) Expedited variance procedures and time extensions.

(1) Notwithstanding the time requirements in paragraphs (a) and (b) of this section, the Department may notify a permit applicant before a draft permit is issued under Rule 37 that the draft permit will likely contain limitations which are eligible for variances. In the notice the Department may require the applicant as a condition of consideration of any potential variance request to submit a request explaining how the requirements of 40 CFR Part 125 applicable to the variance have been met and may require its submission within a specified reasonable time after receipt of the notice. The notice may be sent before the permit application has been submitted. The draft or final permit may contain the alternative limitations which may become effective upon final grant of the variance.

(2) A discharger who cannot file a complete request required under paragraphs (a)(2)(ii) or (a)(2)(iii) of this section may request an extension. The extension may be granted or denied at the discretion of the Department. Extensions shall be no more than 6 months in duration.

(d) Modifications to water quality based effluent limitations for POTWs and Non-POTWs Applications for a modification to a water quality based effluent limitation imposed by EPA Under Section 302 of the Clean Water Act shall be made prior to the close of the public comment period under Rule 41.

\section{7 - Decision on Variances.}

(a) The Department may grant or deny requests for the following variances (subject to EPA objection under 40 CFR 123.44): 
(1) Extensions under Section 301(i) of the Clean Water Act for delay in completion of a publicly owned treatment works;

(2) After consultation with the Regional Administrator, extensions under Section $301(k)$ of the Clean Water Act based on the use of innovative technology; or

(3) Variances under Section 316(a) of the Clean Water Act for thermal pollution.

(b) The Department may deny, or forward to the Regional Administrator with a written concurrence, or submit to EPA without recommendation a completed request for:

(1) A variance based on the presence of "fundamentally difference factors" from those on which an effluent limitations guideline was based:

(2) A variance based on the economic capability of the applicant under Section 301 (c) of the Clean Water Act:

(3) A variance based upon certain water quality factors under Section $301(\mathrm{~g})$ of the Clean Water Act: or

(4) A variance based on water quality related effluent limitations under Section 302(b)(2) of the Clean Water Act.

(c) The Regional Administrator may deny. forward, or submit a request for a variance listed in paragraph (b) which is forwarded by the Department with a recommendation for approval, to the EPA Office Director for Permits and Enforcement.

(d) The EPA Offiee Director for Permits and Enforcement may approve or deny any variance request submitted under paragraph (c). If the EPA Office Director approves the variance, the Department may prepare a draft permit incorporating the variance. Any public notice of a draft permit for which a variance or modification has been approved or denied shall identify the applicable procedures for appealing tht determination under 40 CFR 124.64

58 - Procedures for Variances. When a request for a variance is filed as required under Rule 56, the request shall be processed as follows:

(a) If at the time that a request for a variance is submitted the Department has received an application for issuance or renewal of that permit but has not yet prepared a draft permit covering the discharge in question, the Department shall, subject to EPA review pursuant to 40 CFR 124.62, give notice of a tentative decision on the request at the time the notice of the draft permit is prepared as specified in Rule 42, unless this would significantly delay the processing of the permit. In that case the processing of the variance request may be separated from the permit in accordance with paragraph (c) of this section, and the processing of the permit shall proceed without delay.

(b) If at the time that a request for a variance is filed the Department has given notice under Rule 41 of the draft permit covering the discharge in question, but that. permit has not yet become final, administrative proceedings concerning that permit may be stayed and the Department shall prepare a new draft permit including a tentative decision on the request, and the fact sheet required by Rule 39 . However, if this will significantly delay the processing of the existing draft permit or the Department, for other reasons, considers combining the variance request and the existing draft permit inadvisable, the request may be separated from the permit in accordance with paragraph (c) of this section, and the administrative disposition of the existing draft permit shall proceed without delay.

(c) If the permit has become final and no application concerning it is pending or if the variance request has been separated from a draft permit as described in paragraphs (a) and (b) of this section, the Department may prepare a new draft permit and give notice of it under Rule 41 . This draft permit shall be accompanied by the fact sheet required by Rule 39 except that the only matters considered shall relate to the requested variance.

59 - Special Procedures for Decisions on. Thermal Variances Under Section 316(a).

(a) Except as provided in 40 CFR Section 124.65, the only issues connected with issuance of a particular permit on which the Department will make a final decision before the final permit is issued under Rules 46 and 55 are whether alternative eftluent limitations would be justified under Section 316(a) of the Clean Water Act and whether cooling water intake structures will use the best available technology under Section 316(b) of the Clean Water Act. Permit applicants who wish an early decision on these issues should request it and furnish supporting reasons at the time their permit applications are filed. The Department will then decide whether or not to make an early decision. If it is granted, the balance of the permit shall be considered permit issuance under these regulations, and shall be subject to the same requirements of public notice and comment and the same apportunity for an adjudicatory hearing.

(b) If the Department, on review of the administrative record, determines that the information necessary to decide whether or not the Clean Water Act Section 316(a) issue is not likely to be available in time for a decision on permit issuance, the Department may issue a permit under Rule 46 for a term up to 5 years. This permit shall require achievement of the effluent limitations initially proposed for the thermal component of the discharge no later than the date otherwise required by State or Federal law. However, the permit shall also afford the permittee an opportunity to file a demonstration under Section 316(a) of the Clean Water Act after conducting such studies as are required under 40 CFR Part 125. Subpart H. A new discharger may not exceed the thermal effluent limitation which is initially proposed unless and until its Clean Water Act Section 316 (a) variance request is finally approved.

(c) Any proceeding held under paragraph (a) of this section shall be publicly noticed as required by Rule 41 and shall be conducted at a time allowing the permittee to take necessary measures to meet the final compliance date in the event its request for modification of thermal limits is denied.

(d) Whenever the Department defers the decision under Section 316(a) of the Clean Water Act any decision under Section 316(b) may be deferred.

\section{0 - Incorporation by Reference.}

The following Federal regulations which are cited in whole or in part in these regulations are hereby incorporated by reference. In the event that any of the requirements set forth in Rule I through 59 shall conflict with the following Federal regulations, then the more stringent standard shall apply. All future amendments to the following Federal regulations are also hereby incorporated by reference in so far as they may be necessary to assure that $\mathrm{Rhode}$ Island maintains an approved RIPDES program and continues to secure this State the benefits of that program:

\section{CFR Part 153}


40 CFR Parts 122, 123, 124, 125, 133. 136, 300, 403, and Subchapter N 39 Federal Register 15202 (May I, 1974)
Appendix A. Tables I - IV [Omitted See 40 CFR 122 Appendix D Tables I - IV published in Environment Reporter, Federal Regulations - 3 at page 131:1001.]

TOXIC mOLLUTANT

Astestos

HAZ1ALOUS SURSTANCES

\section{Aceraidenyde}

2. Aestuc verd

3. Acetie annvoride

4. Aceione evanonydrín

3. Aetryl bromid

5. Aertyl entorico

7. Acrotain

3. Acrvianitrile

9. Adiers send

10. Alarin

11. Allyl aleamol

12. Allyl eqloride

13. Aluminum sublate

14. Ammonu

13. Ammonium serexte

ig. Aminonium benzeate

17. Ammonium olevoonse.

:6. Immonium bienromste

19. Ammoniwn bifluoride

20. Ammoniun bisulfite

21. Ammanum erovmate

22 Ammonium exponare

23. Ammonium enionde

24. Ammonius erremaer

33. Ammonium eisrase

75. Ammenium llucrobore

27. Ammonium Huoride

48. Ammenium mvorosido

39. Ammonium analart

30. Ammeniun viliegtluomdo

2:. Ammonium suttamate

72. Ammonium sultio.

2. Ammaniun relfite

34. Anmenium :arrete

7. Ammonum iniogyanat:

E. Anmenoum eniosullate

37. Imvi dentate

12 Aniline

7. Antimony oentacniorio

20. Anlimony jotasuum :annte

11. Antimany tpioremm

12. Animony ipientoria

dj. Antimont ifitivoria

44. Antumony trioxide

15. Arrenic arusitio

s6. Arenne sentozio.

d7. Arsunie trientorice

18. Arune tnowion

49. Aranve ertulutic

50. 3urium eranies

51. Sonzenes

52. 3nxoue sed

91. 3 ensoniente

S4. Benrovl enlorid

s. Benryl eniarido

58. Invllium enlorias

57. Govillium Ilyoride

52. Benvlium nitrate

59. Jutrluestate

50. n.Jutyiontnalate

51 3ur:?

52. Zuivive seid

52. Giomi.sm actrate

5is Edinium gromia

53. Ei:-7.נm salorias

55. Edlerum arsunare

57. Edicivim arsenite

52. Ejic. . T ejpoide

\%9. Esierutr enromat
70. Caleium varide

71. Calejun dodecribententesullonte

77. Ealeium hyooenlaries

73. Cagran

74. Curberrt

73. Curoduran

70. Curoen disultide

77. Curbon tetreenloride

78. Cilorane

78. Chlerine

90. Chtoroemzene

81. Chloroform

32. Ciloreovritas

83. Chiorasullonic acid

34. Chromie active

39. Eiromic aeid

55. Girromic sullate

37. Snremeus eniaride

38. Esoatious aromice

39. Coovrous 10 imar.

90. Cosurpus iulfamart

91. Coumana:

92 Crist

93. Crovondelanyo.

34. Evaris vertate

95. Cuane sestoursense.

ge. Cuerve enloride

97. Cuarie nitre

98. Cuerve exalat

99. Cuorie sulfu

1C0. Cuope sultate immoniated

101. Coprte iantice

102 Cranoqun emiaries

103. Cretonexar

104. 2.4-0 iesd (2. 4bieniaroonenaxvactie actel

109. 2.4-0 exten 12,4.0icriorognenoxyscatie setc estersl

105. Dot

io7 Ciasines

1Ca. Oieanb

169. Oichiogend

19. Dieniom

i i . Oieniapooenzem

112 Dienloropropan

113. Jiclierogioane

114. Dichtoraprouene dichoororogane mix

115. 2.2.0ieniaroorobionie sed

119. Oientorne.

17. Olivarm

17. Olatmiamm

19. Dimetrutamine

120. Dinikeenzene

121. Cinrtoonemo

122. Gintrotetume

1 23. Qigus

124. Divullaten

is. Giwen

135. Ooenovibenzerull onte sed

127. Enoosultan

129. Endrin

1 79. Esienioromudrin

1:0. E:Mion

131. Envibenzane

132. Einvienediamine

1j3. Einviene dioramioe

134 Einviene Jienioride

135. E:nviene Jiaminetetracetie seid

ISDTA|
138. Ferpic ammonium sitrate

1 37. Ferric ammonium ondiare

15. F smie =nior toe

139. Farric fluariar

1 \&Q Forric nutrate

141. Farric gullate

142. Ferrous ammonium sulfst

141. Farrous chlorive

14. Feprous inlist

149. Formalcunvo

148. Formie tod

147. F.tmane sed

i 48. Eufury

149. Butnion

150. Heetacrier

151. Hexzentorocredoentadiene

IS2. Myaroentorte aed

15]. Hydralluarie aed

154. Ararogen Granide

153. Hrarom aulie

isd. I soeven

157. I werapandarnine

todecribenzentulfonat.

158. Kalentan

159. Keoon

160. Lide acrer.

15T. Losd ar renate

162. Lead entopic

183. Lesd Huevarate.

164. Lend flowite

155. Late iodien

165. Lind nitre

167. Leid stevere

162 . Lade iwtare

iธร. Lsad rultion

170 . Liad iniocranate

179 Loname

172 Lifnium soromare

17. Aatatnion

17. .:ivere jea

i75. Batenc annvarie

i75. herearodimeinur

177 ivieurie svaniel

1 :9. dereurie nitrate

179. Aaresric sullata

30. Aereurie :miocranate

181. Aleresians niteata

192. Metnaxventa

13.. ietnvi meresaran

124. inetnvi merneervlate

ias. Metmy saratnon

i gE. Ainvinonos

197. .1e x ecaroat

138. dioncetnviamine

1 a9. Monomernviamin

190. Naino

191. Hatnziene

192. sadrnente aerd

92. "fiex el ammonium rultat:

34. Vickel enlarioe

135. "liexel avaromioe

: 38. Slickel aif:ate

197 d.ckel sullate

1 ga. "Hhiple jeja

139 ditracenzene

-20. Vitro=sn jiomide

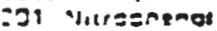

:ZE. 'ilirziduene

CZ. Jualomaicanvae 


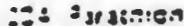

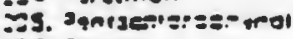

:-3. Jupral

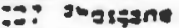

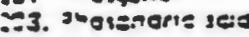

:3. Insisingrus

-. Imosenorus =xverieruse

:11. Inosenarus sar parulide

:- Ingsenarus :- strofle

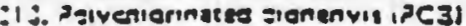

$\because:$ : stsisem dessanate

-3. Jotaserum wranite

$\because 3$. Istasyum jesromate

217. Jgrassum enromass

213. गztsssium Gianten

iig. 3эtasมum nvoroxice

-D. satsasum oermanganate

iz1. Meseargits

i-2 jopzienie dese

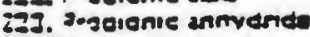

21. 2egovione axide

373. Myreunrins

213. Sunatine

227. Imarennot

7.3. Solenium axias

27.9. Silver alcrest

-0. Sodium

69. Sodiun updenate

72 socium serentr

Zi. socium sicspomate

2.4. Sodium alluaries

TEs. Soarum arrulit:

:-5. Sodiun eqromat.

37. Sodium ov inies

Appendix B [Omitted. See 40 CFR 122 Appendix B published in Environment Re. porter Federal Regulations - 3 at page 131:1001.]

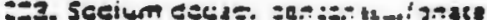

2:9. Sodium !" warree

240. 3odium ave: 3 surfiea

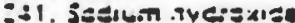

:1:. justiun 7vsectiones

:23. Jodium mataviste

:-i. judiun niterte

:5. Joeum anosenach i jieasucl

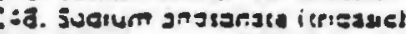

:- joetum utenife

-3. Ji: sncium etromace

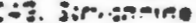

Eg. Striptine

:I1 suifurte aese

:37. Juiviur tondentorder

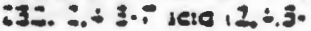

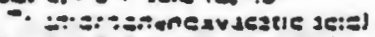

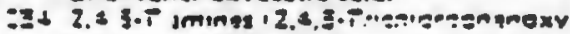
:

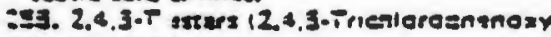
dentse ade eatory

288. 2.4.5.T alts 12.4.3-Trientoroanenomy xante sec saitil

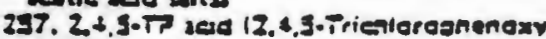
aroanose jefel

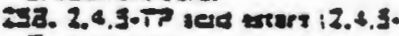

Tricmareantmaxy aroeanoic sed yem

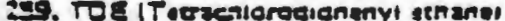

3EO. Torreverni leas

is1. Terseemi sproenosenate

1E2. Thalium rutate

303. Taluen

38. Toxadnene

is5. Triegtarden

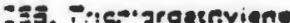

797 inetiaroongnol

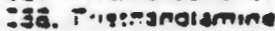

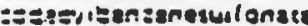

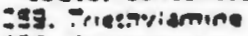

27. Primuerrsiamine

¿i) Uranvi ses:sta

272. Jeanyl nicrate

77:. Visadum =entoxiga

if. 1/anadi sullate

275. Vinvl dentate

273. Vinulidane etiorioa

277. Xulene

278. Xyianot

279. Zine dearara

30. Ene immoniun catorice

31. Ene jorats

337. Ene sromide

933. Ene carsonate

i34. Ene entorter

285. Zne Fiane

236. Zne lluand

197. Zine formate

i38. Zne nveromulanate

399. Zine nirrate

30. Ine anmel rulfonate

291. Ene amasonide.

292. Ene sliesptuane.

จ93. Zne rulate

i96. Ereonium nierat

295. Zireamum sarawn llourge

996. Ziresnnm sulfars

797. Zireaniun entraeriones
Appendix C [Omitted. See 40 CFR. 122 Appendix $C$ published in Environment Reporter Federal Regulations - 3 at page 131:1001.]
Appendix D [Omitted. See 40 CFR 122 Appendix A published in Environment Reporter Federal Regulations - 3 at page 131:1001.]

\section{AprolidiX E}

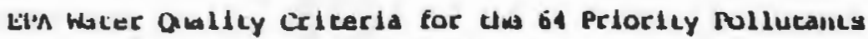

(UNLIS AHL IN MCIO LINAS PEN LIIUII)

corrouns

Acenafitlienes

Acrolein

Acrylonitrile

Mdrivoleldrin

Alur in

Dielulitn

Antimony

Arsenic

Astrescos

Denzerte

Benzidine

Beryllium
AOAric LIFL Cu'rem fresturater Sallwawer
$1 /$

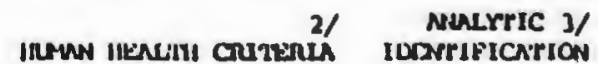

$\begin{array}{cc}\text { B.N.E.O. } & 3 \\ \text { V.o. } & 2 \\ \text { v.o. } & 100\end{array}$
$20 \mathrm{o} / \mathrm{-}$
$320 T / 700 \mathrm{~T}$
$0.58 \mathrm{c} / 6.5 \mathrm{c}$

$\begin{array}{ccc}3 \operatorname{Max} & 1.3 \max & 0.00074 \mathrm{c} / 0.00079 \mathrm{c} \\ 0.001924 \text { lue. } 0.001924 \text { hr. } & 0.00071 \mathrm{c} / 0.00076 \mathrm{C}\end{array}$

2.5 max 0.71 maix

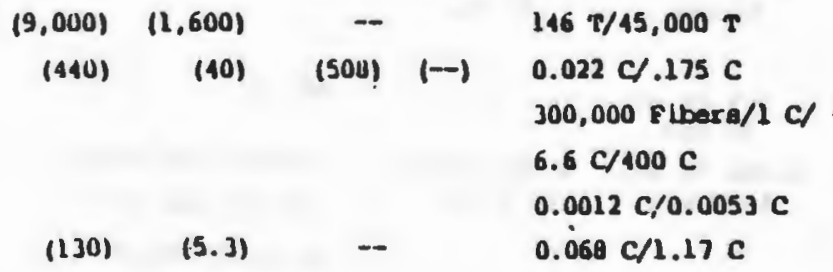

$\begin{array}{lc} & 0.003 \\ \text { P. } & 0.006 \\ \text { H. } & 3 \\ \text { M. } & 53\end{array}$

o.

V.o. 100,000 f iber

B.N.\&.o.

0.2

M.

0.05

0.3 


\section{APPENDIX E (Cont'd.)}

compons

\section{Cachinitu}

Curtur tutrachloritlo Chilorilasue

CHor inaced luenzerlas

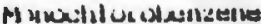

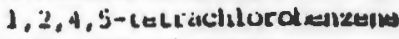

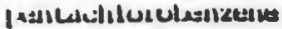

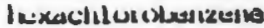

Quorinated turanes

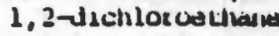
1,1,1-tricluloroelilane 1,1,2-trichlotoeclane 1, 1,2,2-entracliloroutluan haxactilorouthaim

Ciloroulkyl Ethers bi is (2-clilotoisoprogryl) ether bis (clulusanistiyl) abler Lis (2-ituoxueviyl) ectier

Gilurinated Naphiclaleres

Chloristated Pheirsla: 3-iturixti iorontienul 4-monceitloroplenol

2, 3-vichlorow venol

2,5-itichlorcultunol

2, o-dicinoroquerol

3, Aflichlorathenol

$2,4, j$-Lichlorqutuenol

2, 4, 6-cricllora dimes ol

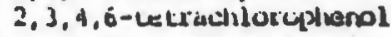

2-mecliyl-4-cliforordumol

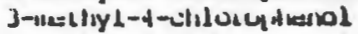

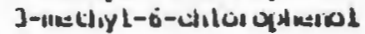

\section{GLOL cToเ2u}

2-Cilorvinearl

C7ircalicus

$$
\text { Clicuilun VI }
$$

Oำx

cyanila

nor

Dichlorobenzenes

Dichlorolienzidine:

Dicillorcetiy leneg 1,1-Dichlorethylewa

2,4-0lchiloroplienol

Dichloropropankes/propanae Dlchlorastopene

\begin{abstract}
1

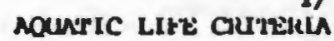
ritesimacer salcuacer
\end{abstract}

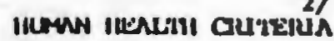

Ansric 3

$0.01224 \mathrm{hr}$. $4.524 \mathrm{hr}$. $10 \mathrm{\%}$ -

$$
1.5 \operatorname{mix} \quad 59 \max
$$

\section{$4.0 \mathrm{c} / 69.4 \mathrm{C}$ \\ $0.0046 \mathrm{c} / 0.0040 \mathrm{C}$}

0.004324 lir. 0.00424 hr.

$2.4 \mathrm{Mux}$

0.09 iax

$499+12001 /=$

$30 \mathrm{~T} / 44 \mathrm{~T}$

74 tros ip

$0.0072 \mathrm{C} / 0.0074 \mathrm{C}$

$9.4 \mathrm{C} / 2430 \mathrm{C}$

$10,400 \% / 1,030,000$ is

$6.0 \mathrm{C} / 41 \mathrm{~B} \mathrm{C}$

$1.7 \mathrm{c} / 107 \mathrm{C}$

$19 \mathrm{c} / 47.4 \mathrm{C}$

$34.7 \mathrm{r}$

$0.000030 \mathrm{C}$

$0.3 \mathrm{C}$

A : .

M.

v.o.

p.

0.04

0.03

v.o.

0.001

v.o.

0.006

0.005

0.006

0.006

0.vul

M.N.E.o.

0.9

U.H.E.O.

0.4

A.E.o.

$0.10 /-$

$0.10 \%=$

$0.040 /$ -

$0.50 \%$ -

$0.20 /$ -

$0.30 \%$ -

$2,600 \div(101 /$.

$12 \mathrm{C}(20) / 36 \mathrm{C}$

$10 /-$

$1.0000 /=$

$3.000 \mathrm{O} / \mathrm{-}$

$20 \mathrm{or}-$

$1.90 \mathrm{c} / 157 \mathrm{c}$

$0.10 /$ -

v.o.

0.015

8.3

0.006

A.E.o.

2
D. 2924 lur.

21 Max

2, 200 Max

5.624 irr.

12 Aax

$3.524 \mathrm{lz}$.

52 Max

0.00124 hre $0.00124 \mathrm{hr}$. 1.1 Plax
$1024 \mathrm{hr}$.

1,260 max

$4.024 \mathrm{hr}$. $23 \mathrm{Mux}$

$0.13 \mathrm{max}$
$.50 \mathrm{r} / \mathrm{-}$

$170,000 r / 3,433,000 \tau$

$1000 \mathrm{o}$ -

$200 T /-$

$0.00024 c / 0.00024 c$ $400 \pi / 2,600 \tau$

$0.103 \mathrm{C} .204 \mathrm{C}$

$0.33 \mathrm{c} / 1 \mathrm{f} .5 \mathrm{c}$ 3090 × $10.301 /$ -

87 $\% / 1410 \%$

M.

M.

o. 5

p.

0.016

B.N.E.O.

0.004

B.N.E.o.

0.1

v.o.

0.006

A.E.O.

2.1

v.o.

0.006 


\section{APPENDIX E (Cont'd.)}

\section{amiours}

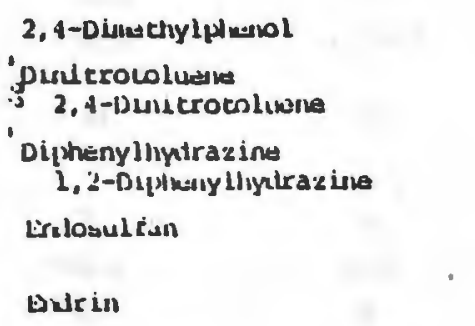

\section{ELtiyllatizente \\ Plisscalicliano \\ inalcustivers \\ lia lcairaljuivay \\ Hetitadiluse}

Ikxachl]utubulind lend

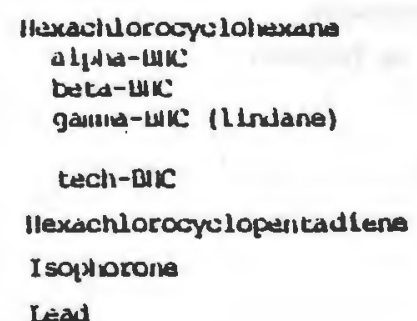

Marcury
Naptlul una
Nickel

Ni trobenzene
Mi Liophenols
2,4 diutro-a-cress!
dinicronkenwl
N1 croscrunines
|1-HL rrosol intethyl auine

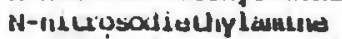

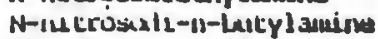
N-nicrosuryol heting
N-MsLlosalifluenylicunitu

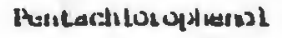
PItetwl
Phichlate escets
diut: cjiyl-ldiclualace
diuLJiY]-[Niclulate

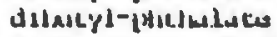
ai-2-ubillexyl-ןhulalate

nourric LItE cIutuis

Frostmaler Saltumitar
NWW.rit: $y$

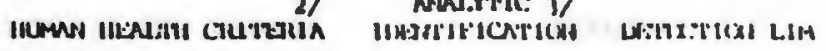
0.05624 lur.
$0.22 \mathrm{max}$
$0.000724 \mathrm{hr}$
$0.034 \mathrm{max}$
$74 r / 159$ r

0.002324 hir. $0.10 \mathrm{Aux}$

0.037 . $12 x$

$0.122 \mathrm{C} / 5.6 \mathrm{C}$

$1000 /-$

$1.1 c / 91 \mathrm{C}$

$1 \dot{\tau}$ -

$1400 r / 3280 T$

$42 x / 5+t$

- 1 -

$1.9 \mathrm{c} / 157 \mathrm{c}$

$0.003424 \mathrm{hx} .0 .003629 \mathrm{hr}$. $0.00270 \mathrm{c} / 0.00285 \mathrm{c}$ $0.52 \mathrm{kHX} \quad 0.1153 \mathrm{kmx}$

$4 .+7 c / 560 \mathrm{c}$

$0.092 \mathrm{c} / 0.310 \mathrm{c}$

$0.163 \mathrm{c} / 0.547 \mathrm{C}$ $0.08024 \mathrm{fic}$.
$2.0 \mathrm{mix}$

$0.100^{\circ} \mathrm{T} / .625 \mathrm{~T}$

$0.123 \mathrm{c} / 0.114 \mathrm{C}$

206 T $(10) /$ -

$520000 \mathrm{~T}$

$.7524 \mathrm{hr}$. (66日) (25) $50 \mathrm{~T} / \mathrm{C}$

74 मbx

0.2024 Irr. 0.1024 . Irr.

$0.144 \% / .146 \mathrm{~T}$.

$-i-$

$5624 \mathrm{hr} . \quad 7.124 \mathrm{hr} . \quad 13.4 \mathrm{r} / 100 \mathrm{~T}$

1100 แax

$140 \max$
A.E.o.

1.7

R.N.E.O.

0.06

B.N.E.U.

10

p.

0.005

p.

0.0119

v.o.

10

B.ti.e.o.

0.05

B.N.t.o.

0.06

v.o.

0.01

b.

0.1102

H.N.E.U.

0.001

๑.

0.002

0.00 :

U. 402

0.001

M.N.E.O.

u. 001

B.N.R.O.

5

i.

42

H.

0.1

B.N.E.U.

2.5

M.

15

$19,000+(300) /-$

13.4 T/765 T

$70 \mathrm{~T} / 14300 \mathrm{~T}$

$0.014 \mathrm{c} / 160 \mathrm{c}$

$0.008 \mathrm{c} / 12.4 \mathrm{C}$

$0.064 c / 5.860 \mathrm{c}$

$0.160 \mathrm{c} / 919 \mathrm{C}$

$19 \mathrm{c} / 161 \mathrm{C}$

1010 $4(300) /$ -

$3500 \times(3000) /$ -

113,000 T/2,900,000 T

$350,000 \mathrm{~T} / 1,800,000 \mathrm{~T}$

$34,000 \mathrm{~T} / 154,000 \mathrm{~T}$

$15,000 \mathrm{~T} / 50,000 \mathrm{~T}$
U.N.E.O.

A.E.o.

5

7

B.N.E.u.

0.]

A.E.o.

A.E. 0 .

B.N.E.O. 


\section{APPENDIX E (Cont'd.)}

ocruvaris

Polychlorinaled blifien
Polynuclear acomatic
Iyplrocarbons (PNI' y)

Seleniun

Seltulte

Sllver

netrachlorosthylene

Tha 11 1

Toliute

Ioxaptuane

I'r I chloroethy lene

Visiyl chiloride

alux
$1 /$

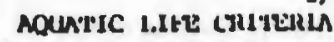

Fresinnter sultuater
$2 / 2$ NAIIrric: 3

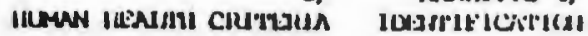

(H:ITLITI III
$0.00079 \mathrm{c} / 0.00079 \mathrm{c}$
1".
0.04
$0.024 \mathrm{c} / 0.311 \mathrm{c}$
B.H.E.O.
0.04

$10 \%$

M.

75

3524 hre. $\quad 5424$ hre

260 Max 410 Mix

1.2 $\max 2.3 \max \quad .5 J T /$

M. 7

- c/ar.s $\mathrm{C}$

v.o.

0.007

M.

1

v.o.

10

0.01324 lí.

$0.070 \mathrm{max}$

$14,300 \mathrm{~T} / 424,000 \mathrm{~T}$

1.6 $\operatorname{Max}$

$0.0071 \mathrm{c} / 0.0073 \mathrm{C}$

p.

0.4
$27 \mathrm{c} / 807 \mathrm{c}$

$20 \mathrm{c} / 5246^{\circ} \mathrm{C}$

100 ptax
4724 Ir. v.o.

0.005

v.o.

0.01

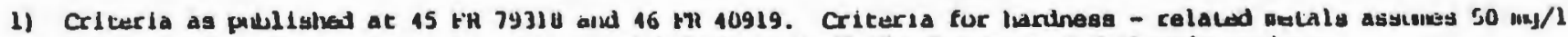

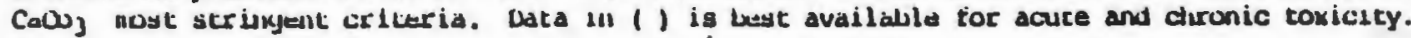

2) Criceria as publisibel at 45 fll 79118 and 46 in $10919^{\circ}$. Basia for oritaria dasignatel as follows:

- $0=$ Oegaiviliquic efticut

t = Iuxicity

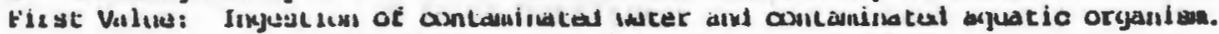

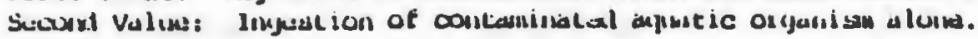

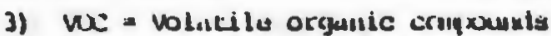

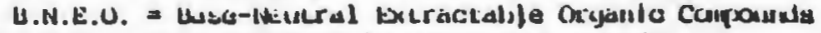

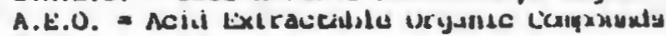

P. = Pescicisiley dixl IOX's

ii. H:Laly

D. Ot!kL

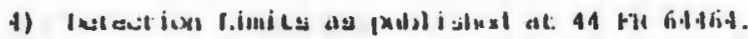

Yomographs for calculating Froude Numcers

and Ollution Ficior
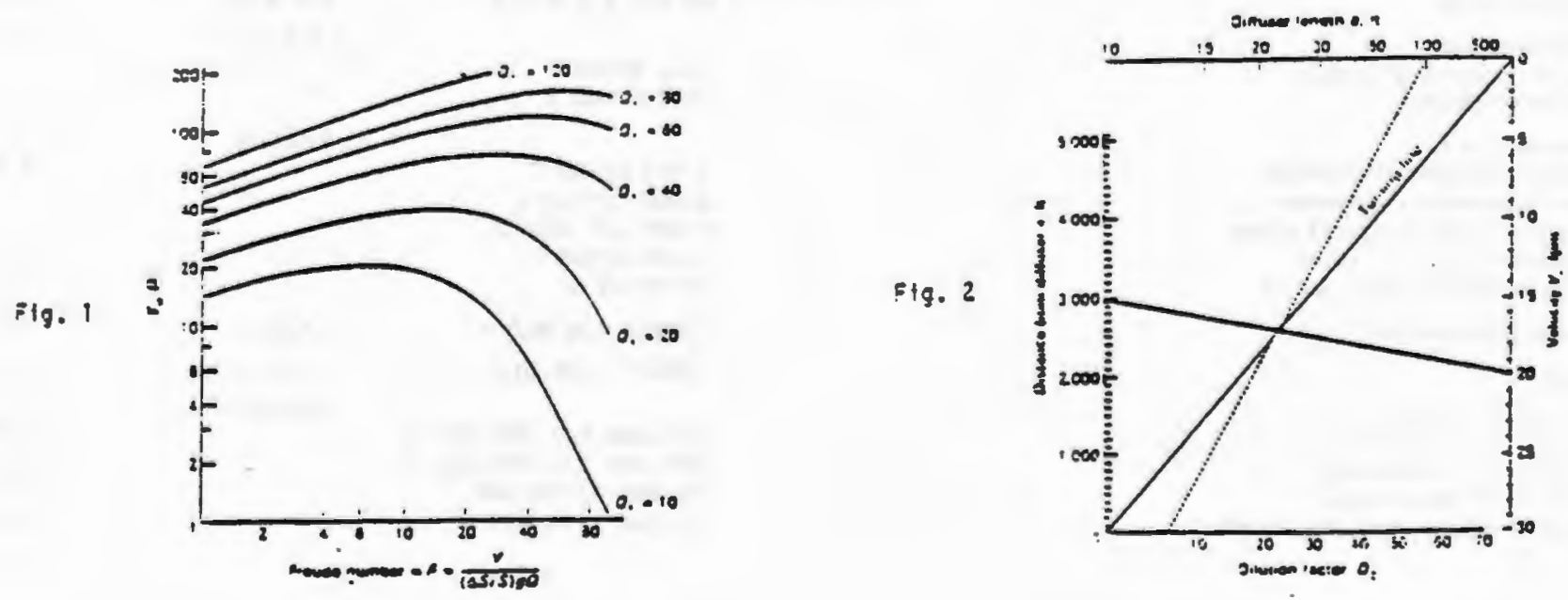


\title{
RHODE ISLAND UNDERGROUND STORAGE FACILITIES RULES
}

\author{
(Rhode Island Department of Environmental Management, Division of Water \\ Resources, Regulations for Underground Storage Facilities Used for Petroleum Products \\ and Hazardous Materials; Adopted April 18, 1985)
}

1. Authority. These regulations are adopted pursuant to Chapters 46-12, 42$17.1,42-35$ and $23-19.1$ of the General - Laws of Rhode Island, 1956. as amended.

2. Purpose. The purpose of these regulations is to implement a registration system and to establish facility design requirements testing schedules, and closure requirements for new and existing underground storage tank systems in order to protect the groundwaters and surface waters of the State from pollution that may result from the underground storage of petroleum products and hazardous materials.

3. Superseded Rules and Regulations. These rules and regulations supersede the Emergency Regulations for Underground Storage Facilities Used for Petroleum Products and Hazardous Materials.

4. Administrative Findings. The following administrative findings are also made a basis for these regulations:

(a) Approximately $30 \%$ of the population of Rhode Island depends upon groundwater as a sole or principal source of water supply.

(b) The principal groundwater resources of the State are located in relatively thin glacial deposits of stratified sand and gravel which underlie about one-third of the State. These aquifers lie close to the surface and are expremely vulnerable to contamination.

(c) A number of small public and private water supplies obtain water from tillcovered fractured bedrock aquifers which underlie about two-thirds of the State. These acquifiers are especially dificult to monitor and to reclaim once contaminated.

(d) A large portion of the State's future water supplies will be developed from groundwater sources due to the limited number of suitable sites for the construction of surface water reservoirs.

(e) The rapid escalation of groundwater contamination by petroleum products continues to cause property damage and poses an imminent peril to human health by the migration of product and/or product fumes into underground utilities and basements, throughout our State.

\section{Applicability}

(a) These regulations apply to new, existing and abandoned facilities at which petroleum product(s) and/or hazardous material(s) serving institutions or industrial, commercial, educational, agricultural or governmental operations are stored underground.

(b) Except for Section 14. Leak and Spill Response, these regulations do not apply to:

(1) On-site underground storage tanks used for storing heating oil and serving a one, two or three family dwelling:

(2) Farm or residential underground storage tanks holding less than $1,100 \mathrm{gat}$ lons and storing motor fuel or heating oil for non-commercial purposes;

(3) Septic tanks;

(4) Storage tanks located in an underground area, that is not part of a secondary containment system such as a basement or cellar, if the tank is situated upon or above the surface of the foor; or

(5) Underground storage tanks used for storing No. 4, No. 5 or No. 6 fuel oil.

(c) Section 9, Existing Facility Requirements, Section 10, New Facility Requirements, and Section 11. Facility Modification do not apply to tanks used for storing No. 2 fuel or jet propuision fuel (JP-1).

(d) Section 13, Maintaining Records, part (a) (6) does not apply to tanks used for storing fuel oil No. 1, 1-D or 2 on site for consumptive use, or to tanks used for storing waste oil.

(e) These regulations shall be construed in harmony with and in addition to any requirements of Rhode Island General Laws Title 23. Chapters 28.21 and $\mathbf{2 8 . 2 2}$ or any orders by local fire chiefs issued thereunder.

\section{Definitions.}

Abandonment means the relinquishment or termination of possession, ownership or control of underground storage. tanks, by vacating or by disposition, without meeting the closure requirements listed in Section is of these regulations.

Closure means the removal from service of any underground storage tank in accordance with the procedures contained in these regulations.

Commenced Construction means that the owner or operator has obtained local approvals or permits necessary to begin physical construction and either has (1) begun a continuous on-site physical construction program; or (2) entered into contractual obligations - which cannot be cancelled or modified without substantial loss - for physical construction of the facility to be completed within a reasonable time.

Continuous Monitoring System means a continuous leak detection and alarm system that is automatic and operates independent of human assistance, that meets industry standards such as those of Underwriters Laboratories (UL), and that is approved by the DIRECTOR.

Diesel Oil means any grade of distillate oil commonly referred to as diesel which is utilized for the purpose of vehicle propulsion.

Director means the Director of the Department of Environmental Management or his/her designee. 
Any documents or reports required 10 be submitted to the DIRECTOR by these regulations should be sent to: Chief, Division of Water Resources, R.I. Department of Environmental Management, 75 Davis Street, Providence, RI 02908.

Dry Season means a seasonal time period when the groundwater table is at its lowest: usually occurring during the months of May-December. Specific dates will be determined on a yearly basis by the DIRECTOR.

Existing Facility means a facility which is in full operation or at which "substantial construction" has been initiated onsite or at which construction on any modification has commenced prior to the effective date of these regulations.

Facility means all contiguous land, structures, facility components and other appurtenances that form a district geographic unit and at which petroleum products or hazardous materials are stored in underground storage tanks.

Facility Component means any underground tank and/or associated pipes, pumps, leak monitoring systems, cathodic protection systems, vaults, fixed containers or appurtenant structures, otherwise referred to as facility components, used or designed to be used for the storage, transmission, or dispensing of petroleum products and hazardous materials and serving institutions or industrial, commercial, agricultural or governmental operations or other uses not precluded by the provisions of Section 5 of these regulations.

Gasoline means a petroleum distillate, or blends of petroleum distillates, having a Reid vapor pressure of 7 pounds per square inch absolute $(48.3 \mathrm{k} \mathrm{Pa})$ or greater and used. for example, for the purposes of vehicle propulsion.

Groundwater means water in the saturated zone beneath the ground surface, and includes all underground waters of whatever nature.

Hazardous Materials means any material defined as a "hazardous substance" by section 101(14) of the Comprehensive Environmental Response, Compensation, and Liability Act of 1980 (42 USC 9605), as amended (see Appendix A). Hazardous materials shall also include any material defined as a "hazardous waste" pursuant to the Rhode Island Hazardous Waste Management Aet of 1978, as well as any of the following materials:

\section{Acetone}

Ethanol

Ethylene Oxide

Methanol

Methylene Chloride

Perchloroethylene

Leak means a loss from or gain to a facility of 0.05 gallons per hour or more of fluid as determined by a "Precision Test", visual inspection, a continuous monitoring system, inventory control, or other appropriate means, and shall be considered a release from a facility.

Line Leak Detection System means a device installed on the discharge side of the pump which is capable of interrupting product flow if there is a leak greater than or equal to 3 gallons per hour.

Local Fire Chief means the person responsible for the administration and direction of a fire department in a fire district or municipality, including a fire administrator or chief or that person's designee.

Membrane Liner means a secondary containment system for underground storage tanks and piping constructed from a membrane sheet material.

Modification means any addition to an existing facility or replacement, restoration, refurbishment or renovation which: increases or decreases the in-place storage capacity of a facility; alters the physical configuration; alters the design and/or specifications of facility components; or impairs or affects the physical integrity of a facility or its monitoring systems.

New Facility means a facility which was not yet in operation and at which "substantial construction" had not yet begun as of the effective date of these regulations.

NFPA Code number 30 means the National Fire Protection Association pub lication number 30 entitled, "Flammable and Combustible Liquids Code", (1984).

NFPA Code number 329 means the National Fire Protection Association publication number 329 entitled, "Underground Leakage of Flammable and Combustible Liquids", (1983).

NO. 1 Fuel Oil means a distillate oil, commonly referred to as kerosene, range oil, or jet propulsion fuel (JP-1).

NO, I-D Fuel Oil means a distillate oil, commonly referred to as light diesel oil.

NO. 2 Fuel Oil means a distillate oil. commonly referred to as home heating oil.
NO. 2-D Fuel Oil means a distillate oil, commonly referred to as medium diesel oil.

NO. 4 Fuel Oil means a distillate oil blend of No. 2 and No. 6 fuel oil.

NO. 5 Fuel Oil means a distillate oil blend of No. 4 and No. 6 fuel oil.

NO. 6 Fuel Oil means a distillate oil, commonly referred to as Bunker-C or residual fuel.

Observation Well means a cased well that intercepts the water table and can be used to detect the presence of groundwater contamination.

On-site means the same or geo graphically contiguous property which may be divided by public or private rightof-way, provided the entrance and exit between the properties is at a cross-roads intersection, and access is by crossing as opposed to going along, the right-of-way. Non-contiguous properties owned by the same person but connected by a right-ofway which he controls and to which the public does not have access, is also considered on-site property.

Operate a Facility means to maintain petroleum product(s) or hazardous material(s) in underground storage tanks at a facility for purposes of storage, use or sale.

Operator means the person in control of or having responsibility for the daily operation of a facility.

Owner means the person who holds title to or lawful possession of a facility or part of a facility.

Person means an individual, trust, firm, joint stock company, corporation (including quasi-government corporation), partnership, association, syndicate, municipality, municipal or state agency, fire district, club, non-profit agency or any subdivision, commission, department, bureau, agency or department of State or Federal government (including quasi-government corporation) or of any interstate body.

Petroleum Product includes:

-Gasoline

-Fuel Oil (No. 1 and 2)

-Diesel Oil (No. 1-D and 2-D)

-Waste Oil

-Gasohol

Precision Test means a test able to determine whether or not an underground storage tank is leaking as defined by NFPA 329, "Underground Leakage of 
Flammable and Combustible Liquids". This test must be capable of accurately detecting a tank or piping leak as small as 0.05 gallons per hour, adjusted for all variables. The test method must be approved by the Director prior to use, and must be conducted by persons who have demonstrated capability to properly conduct the test as determined by the Director.

Release means any spilling, leaking. emitting, discharging, escaping, leaching or disposing from an underground storage tank into groundwater, surface water or subsurface soils.

Remove From Service means to cease to operate a facility component.

Spill means a loss of petroieum product or hazardous material in a manner other than a leak. occurring on the property where a facility is in operation. and such that the product or material is likely to enter ground water or surface water. and shall be considered a release from a facility.

Spill Containment Basin means a device installed in fill pipe manholes that prevents petroleum product or hazardous ma. terial spills from leaching into the soil and ground water.

Substantial. Construction means that a continuous on-site physical construction program has progressed to a point where at least $25 \%$ of the total project is completed or which represents an expenditure of more than $25 \%$ of the total cost of the project for materials which are at the site.

Substantial Modification of a facility means modification to a facility, facility component or new facility plans that would conflict with information provided to the Director in application for a certificate of registration or that would be expected to result in reduced performance of a facility component as it relates to leak prevention or detection. Such modification includes but is not limited to:

(1) The installation of tanks not recorded on the application for a certificate of registration for the facility;

(2) Underground storage tank repair, relining or replacement;

(3) For petroleum products, changes in type of product stored (gasoline. No. I Fuel Oil, No. 2 Fuel Oil, No. 1-Diesel Oil, No. 2-D Diesel Oil, Waste Oil, or Gashol);

(4) For hazardous materials, changes in the material stored;

(5) For a New Facility, alterations to the site plan;
(6) Changes in the design or specifications of a facility corrosion protection system;

(7) Changes in the design, specifications or location of facility leak monitoring equipment.

Surface Water means a body of water whose top surface is exposed to the atmosphere and includes all waters of the territorial sea, tidewaters, all inland waters of any river, stream, brook, pond or lake and wetlands.

Underground means 10 percent or more of the volume of facility components (storage tanks and piping) is buried in the ground.

Underground Storage Tank means any one or combination of tanks (including underground pipes connected thereto) which is used to contain an accumulation of petroleum product or hazardous material, and the volume of which (including the volume of the underground pipes connected thereto) is 10 percent or more beneath the surface of the ground.

Vault means a secondary enclosure which houses an underground storage tank, contains any leaks from the tank. and provides protection from corrosive soils.

Waste Oil means used or spent oil of any kind, including but not limited to those oils from automotive, industrial, aviation and other source categories.

\section{Facility Registration}

(a) The operator of a facility shall apply for and obtain a certificate of registration from the Director in accordance with these regulations and pursuant to the following schedule:

(1) New Facilities, shall apply for and obtain a certificate of registration before commencing construction.

(2) Existing facilities, including facilities where modifications were commenced prior to October 9, 1984 (the effective date of the Emergency Regulations for Underground Storage Facilities), shall apply for a certificate of registration by April 9, 1985.

(b) An application for a certificate of registration shall be submitted on forms provided by the Director, and shall include but not be limited to the following:

\section{(1) New Facilities}

(i) A set of detailed engineering plans and specifications of the project, including operation and maintenance requirements, that have been certified by a registered professional engineer.

(ii) A site plan including all of the information listed below:

(A) Proposed location of all tanks, piping. and dispensing pumps.

(B) Proposed location(s) of on-site observation wells.

(C) Location of all private and public water suppiy wells within 1,000 feet of the facility location.

(D) Proposed building locations

(E) Legal boundaries

(F) North Arrow

(G) Description of and specifications for all proposed leak monitoring systems.

(iv) Size, construction material of tanks. and type of material stored.

(2) Existing Facilities

(i) The results of any testing conducted on all tanks and associated piping (if available).

(ii) Size, age, and construction material of tanks, type of materials stored, and existence of tank and piping protection devices.

(iii) A site plan including all of the information listed below:

(A) Location of all tanks, piping, and dispensing pumps.

(B) Location of existing, on-site monitoring wells.

(C) Building locations

(D) Legal boundaries

(E) North Arrow

(F) Description of and specifications for all leak monitoring systems in operation.

(iv) A description of all spills and leaks that have occurred at the site.

(c) All certificates of registration issued under the. "Emergency Regulations for Underground Storage Facilities Used for Petroleum Products and Hazardous Materials", adopted 9 October, 1984, shall remain in full force and effect provided the owner and operator submit a written certification in accordance with Section 16 of these regulations.

(d) Failure to obtain a certificate of registration in accordance with these regulations shall constitute a violation of these regulations and may subject the operator to penalties referenced in Section 20, Penalties. An owner or operator of a Facility that has failed to obtain a certificate of registration in accordance with these regulations shall immediately implement facility closure procedures in accordance with Section 15 of these regulations and obtain a certificate of closure. 
8. Denial, Modification or Revocation of Certificate of Registration

(a) The DIRECTOR may, after at least twenty days notice in writing to the person or persons affected, and after a hearing, if requested by the affected person or persons, deny, modify or revoke a certificate of registration for cause including, but not limited to:

(1) Information indicating that the storage, location and/or operating procedures pose an immediate threat to public health or the environment:

(2) The information submitted by the application was incomplete, false or misleading:

(3) Circumstances on which the certificate was based have materially and substantially changed since the certificate was issued.

(b) Upon the denial or revocation of the certificate of registration the owner or operator shall immediately implement facility closure procedures in accordance with Section 15 of these regulations and obtain a certificate of closure.

9. Existing Facility Requirements

(a) All underground storage tanks at existing facilities that are equipped with remote pumps shall be fitted with a line leak detection system within two (2) years of the effective date of these regulations.

(b) All underground storage tanks at existing facilities shall be fitted with spill contaiument basins around all fill pipes within two (2) years of the effective date of these regulations.

(c) All existing facility components (underground storage tanks and piping) which do not conform to the new facility requirements listed in Section 10 shall meet the following requirements:

(i) All existing facility components (tanks and piping) that were installed on or after January 1, 1965 shall be precision tested within two (2) years of the effective date of these regulations.

(ii) All existing facility components (tanks and piping) that were installed prior to January 1. 1965 shall be precision tested within one (1) year of the effective date of these regulations, and annually thereafter.

(iii) All existing facility components (underground storage tanks and piping) for which the date of initial installation is known and verifiable and that do not meet the new facility requirements listed in Sec- tion 10 shall comply with one (1) of the following:

(A) The underground storage tank(s) and piping shall be precision tested in accordance with the following schedule (years after initial installation):

$$
5,8,11,13
$$

Precision testing shall be conducted on an annual basis for the underground storage tanks and piping after 13 years of the date of tank installation.

(B) A continuous monitoring system or systems compatible with the product/material stored and approved by the DIRECTOR shall be installed within two (2) years of the effective date of these regulations; the underground storage tank(s) and piping shall be precision tested at five year intervals following the installation of the monitoring device; the underground storage $\operatorname{tank}(\mathrm{s})$ shall be precision tested biennially after 20 years of the date of tank installation.

(d) All existing facility underground storage tanks for which the dates of installation are unknown or unverifiable shall be precision tested within one (1) year of the effective date of these regulations, and annually thereafter.

(e) Results of all precision tests required in this section shall be submitted to the DIRECTOR within 15 calendar days of the date of test completion; or in accordance with Section 14, Leak Response.

(f) Written verification of compliance with parts (a), (b), and (c) (iii) (B) of this section shall be submitted to the Director within 15 calendar days of installation of the required equipment.

(g) All continuous monitoring systems shall be tested by the operator on a monthly basis to ensure that they are operating effectively. Records of such tests shall be maintained in accordance with Section 13 Maintaining Records.

(h) The operator of an existing facility may, in accordance with Section 18 of these regulations, seek a variance so that existing facility components (underground storage tanks and piping) may be regulat. ed in accordance with new facility requirements of Section 10 of these regulations.

[ (i) Reserved for existing facility requirements for underground storage tanks used for storing No. 2 fuel oil.]

10. New Facility Requirements.

(a) All facility components and all related equipment shall be installed, used, and maintained according to the manufacturers specifications and instruction and NFPA Code 30.

(b) All new facility components (underground storage tanks and piping) shall be precision tested upon completion of the installation, but before operation. Results of the precision test shall be submitted to the DIRECTOR within 15 calendar days of test completion or in accordance with Section 14, Leak Response.

(c) All underground storage tanks at new facilities shall be fitted with spill containment basins around all fill pipes.

(d) Underground Storage Tanks

((1) All new underground storage tanks shall be constructed with materials that are compatible with the stored material or product, suitable for the expected external environment, and meet the following minimum requirements.

(i) Steel Tanks - Underwriters Laboratories (U.L.) Listed Standard 58 steel tank or other national laboratory standard approved by the DIRECTOR.

(ii) Fiberglass Tanks - Underwriters Laboratories (U.L.) Listed Standard 1316 fiberglass tank or other national laboratory standard approved by the DIRECTOR.

(2) All tanks shall have one-quarter inch steel wear plates centered under all openings with minimum dimensions of 8 " $\times 8$ ".

(3) All tanks shall have a submerged fill tube.

(4) All tanks shall be factory tested at a minimum of five pounds per square inch guage and guaranteed tight by the manufacturer.

(c) Pipe. Fittings and Pumping Systems

(1) All new facilities shall have piping meeting or exceeding the following requirements.

(i) Cathodically protected schedule 40 steel pipe.

(ii) Nonmetallic pipe listed by U.L. or other national laboratory approved by the DIRECTOR.

(2) All delivery piping systems using a remote pump shall be equipped with a line leak detection system.

(3) All metallic delivery piping shall employ swing joints at all changes in direction.

(4) All delivery systems employing a suction pumping system shall use one only check valve in any suction line.

(5) All delivery systems shall be pres- 
sure tested at $150 \%$ of the working capacity (minimum of 50 pounds per square inch gauge) and pressure shall be maintained during the test for a minimum of one hour. Testing shall be conducted prior to backfilling of the delivery system pipe network.

(6) All piping shall be compatible with all of the products transported and tank materials used at the facility.

(7) The terminus of remote piping systems shall have an emergency shutoff valve at the base of the dispensing unit to shut off product flow in the event that the dispensing pedestal is displaced or exposed.

(f) Corrosion Protection

(I) All tanks and their piping systems shall be protected by one of the following:

(i) A properly engineered, installed and maintained cathodic protection system in accordance with recognized standards. such as U.L. of Canada ULC 603.1-M-1982, "Standard for Galvanic Corrosion Protection Systems for Steel Underground Tanks for Flammable and Combustible Liquids", Steel Tank Institute Standard No. STI-P3, "Specification for STI-P3 System of Corrosion Protection of Underground Steel Storage Tanks - 1983". and National Association of Corrosion Engineers Standard RP-01-69 (1983 Rev.) Recommended Practice "Control of External Corrosion of Underground or Submerged Metallic Piping Systems".

(ii) Corrosion resistant materials such as fiberglass reinforced plastic, or fiberglass reinforced plastic coatings; or equivalent approved system as listed by the American Society for Testing and Materials (ASTM) or other national laboratory approved by the DIRECTOR.

(g) All new facilities shall comply with one (1) of the following requirements:

(1) Installation of a continuous monitoring system compatible with the product/material stored and approved by the DIRECTOR, and precision testing of the facility (tanks and piping) at five year intervals until a tank age (years after initial installation) of twenty years and then biennially thereafter. Results of precision testing shall be submitted in writing to the DIRECTOR within 15 calendar days of the completion of the test, or in accordance with Section 14, Leak Response. Continuous monitoring systems shall be tested monthly in accordance with Section 9 (g).

(2) Installation of double-walled tanks with a continuous interstitial monitoring system and a secondary containment piping system. The tanks and piping shall be listed by a national laboratory that is approved by the DIRECTOR.

(3) One of the following secondary containment systems approved by the DIRECTOR, with a continuous monitoring system inside the containment system:

(i) Vault

(A) The vault shall be a continuous structure which is impervious to water and the stored product.

(B) The floor shall be sloped at least $1 / \% "$ per linear foot.

(C) All openings (i.e. manholes, fill pipes, etc.) shall be watertight.

(D) The tanks shall be installed and properly anchored in the vault in a manner consistent with acceptable engineering practices and standards for safety.

(ii) Membrane Liner

(A) The membrane liner shall have a permeation rate no greater than 0.25 ounces per square foot per 24-hours.

(B) The permeation rate shall be the maximum rate of transport over time of the product stored.

(C) The volume swell of the liner following 24-hours of immersion in the stored product shall not exceed 3 percent of the original membrane thickness

(D) The maximum change in elongation of the liner following 24-hours of immersion in the stored product shall not exceed 5 percent.

(E) The liner Shore D hardness after 24-hours of immersion in the product stored shall be within 5 points of the original hardness.

(F) The rate of transport through the liner material of the product stored shall not be greater than 6 percent by weight.

(G) The solubility of the liner shall not exceed 0.1 percent by weight in a 24 -hour period.

(H) The liner seam strength shall be equal to the tensile strength of the parent material.

(I) All testing of material shall be performed using accepted engineering practices approved by the DIRECTOR for materials tested. The liner shall be installed under the supervision of the manu- facturer of the secondary containment membrane liner system.

(J) The tanks shall be installed and properly anchored in a manner consistent with acceptable engineering practices and standards for safety.

(iii) Approved Equal Secondary Containment System - any containment system that can be proven to be equivalent to the above sections (i,ii,) may be used subject to the approval of the DIRECTOR.

(h) Observation Wells

(1) Any new facility that the DIRECTOR determines to be located in an area where a leak could affect groundwater that may be used for present or future drinkings purposes, in a watershed of present or future public water supply. or in an environmentally sensitive area shall have a minimum of three (3) observation wells meeting the specifications given below. Factors to be considered by the DIRECTOR in making this determination will include but not be limited to groundwater classifications developed by the DIRECTOR or the U.S. Environmental Protection Agency (EPA), the location of sole source aquifers designated by the EPA; groundwater studies such as those of the U.S. Geological Survey and Water Resources Board, the location of sensitive or protected areas designated by local governments, and the location of public drinking water supplies.

(2) Wells shall be located in such a manner as to triangulate the facility. The location of the observation wells and/or the requirement of additional wells is subject to the approval of the DIRECTOR. Observation wells shall be constructed as described:

(i) The screen portion of the wells shall extend a minimum of $S$ feet below the groundwater surface for the average water table elevation at the site during the dry stison. The screen shall be open to the water surface at all times. The maximum well depth shall be thirty feet unless otherwise specified by the DIRECTOR.

(ii) The screen shall be of sufficient length to compensate for seasonal fluctuations in the water table.

(iii) All wells shall have a minimum inside diameter of two (2) inches and be constructed using a minimum of schedule 40 PVC piping.

(iv) All wells shall have bottom caps. 
(v) All wells shall be gravel packed and grouted.

(vi) Where possible the wells shall have a mounded surface seal around the well casing and an above grade locking security cover. If the well must be finished at ground level, a tamper resistant cover that prevents surface runoff from entering the wells shall be used.

[(i) Reserved for new facility requirements for underground storage tanks used for storing No. 2 fuel oil.]

11. Facility Modification.

(a) No substantial modification may be made to an existing or new facility for which an application for a certificate of registration has been filed or for which a certificate of registration has been obtained without prior written notification to and approval by the DIRECTOR.

(b) All modification to or replacement of existing facility or new facility components shall be made in conformance with the requirements of Section 10, New Facility Requirements.

(c) Used tanks meeting the specifications given in Section 10, New Facility Requirements, can be installed in an existing or new facility provided:

(i) the used tanks have been inspected and tested by the manufacturer;

(ii) the used tank has been certified by the manufacturer to be reusable for the product to be stored; and

(iii) the used tank is given the same warranty by the manufacturer as given to a new tank.

(d) Underground storage tanks can be repaired or relined once provided:

(i) the DIRECTOR has approved the repair or relining method;

(ii) the tank is precision tested following tank repairs or relining. and no leaks are detected: and

(iii) the method for repairing or relining is compatible with the product or material stored.

\section{Sole Source Aquifers.}

(a) Existing facilities located in sole source aquifers, as designated by the U.S. Environmental Protection Agency, shall be subject to additional monitoring and testing requirements as determined by the DIRECTOR to be necessary for aquifer protection.

\section{Maintaining Records.}

(a) All owners or operators of new and existing facilities shall maintain on the facility premises records of:
(1) all data used to complete the application for the certificate.

(2) all calibration and maintenance performed.

(3) strip chart, electronic recall device and/or manual recordings for any continuous monitoring instrumentation.

(4) any monitoring, leak detection system, inventory control system and/or tank testing.

(5) monthly tests of continuous monitoring systems as required in Section 9 and 10.

(6) a daily inventory of the product or material stored, including the following minimum information:

(i) a record of all inflows;

(ii) a record of all outflows;

(iii) a daily reconciliation between inflows, outflows and volume on hand:

(iv) written daily entries of any unusual occurrences that might affect the inflow, outflow or volume on hand;

(v) written entries explaining in detail any adjustments to the records.

If such record keeping indicates a discrepancy of $1 \%$ or more of total volume stored in any tank, as a minimum, on a weekly basis, the owner or operator shall report such discrepancy in accordance with Section 14, Leak and Spill Response.

(b) Records of the information listed in part (a) shall be maintained for a period of three (3) years from the date they are made, or for such longer periods as required by the DIRECTOR in an unresolved enforcement action.

(c) The facility owner or operator must make available to the DIRECTOR, upon request, all records which the DIRECTOR feels pertinent to the enforcement of these rules and regulations.

(d) Section (13) (a) (6) does not apply to tanks used for storing fuel oil (No. I. 1-D, or 2) on site for consumptive use, or to tanks used for storing waste oil.

\section{Leak and Spill Response}

(a) Any owner or operator who is aware of or has cause to suspect a leak or spill from a facility shall report it immediately to the local fire chief and the DIREC. TOR. The owner or operator shall file a written report with the DIRECTOR within seven (7) calendar days of the time the leak or spill was first discovered and shall include the known or presumed cause of the leak or spill, results of any tests, inventories, monitoring or inspections that indicate a leak or spill, the known or estimated quantity and type of product or material leaked or spilled, and the length of time the leak or spill was occurring.

(b) At the DIRECTOR'S request, the owner shall arrange to precision test any facility component (tank and piping) which the DIRECTOR has good cause to suspect is leaking within 24-hours of the request. If no leak is detected, a written report of test results shall be submitted to the DIRECTOR within 15 calendar days of test completion. A detected leak shall be reported in accordance with part (a) of this section.

(c) All leaking facility components must be emptied within 24 hours of discovery of the leak, and shall remain empty until such time that the leaking components are repaired or replaced in accordance with the requirements of Section 10 and Section 11. or until the facility component is permanently closed in accordance with Section 15.

(d) The owner or operator of a facility that is located on property at which a leak or spill has occurred or at which the DI. RECTOR has good cause to suspect that a leak or spill has occurred shall install observation wells on the property at the DIRECTOR'S request. The number, construction and placement of these wells shall be approved by the DIRECTOR.

15. Closure

(a) Abandonment of underground storage tanks is prohibited.

(b) Temporary Closure - The owner or operator of underground storage tanks that are removed from service for 180 days or less shall:

(1) cap and secure against tampering all fill lines, gauge openings and pump suction lines;

(2) keep the vent lines open;

(3) maintain records regarding:

(i) underground storage tank location and size:

(ii) date on which underground storage tanks were taken out of operation: and

(iii) the procedures used to maintain the Facility in a safe condition.

(c) The Director may extend the period of temporary closure of an underground storage tank or tanks to more than 180 days for good cause. Petitions for extension must demonstrate good cause and be filed with the DIRECTOR within 60 calendar days following the date the underground storage tank(s) is/are temporarily removed from service. 
(d) Permanent Closure - All owners or operators that remove any underground storage tank from service for more than 180 days and have not been granted an extension of temporary closure by the DIRECTOR or who have abandoned any tank(s) shall:

(1) Comply with the procedures for closing the underground storage tank(s) in accordance with part (e) of this section:

(2) Apply to the DIRECTOR for a certificate of closure at least 10 days prior to the date the tank is to be permanently removed from service in accordance with the provisions of this section. Such application shall include:

(A) The date the tank is to be permanently removed from service in accordance with the procedures outlined herein:

(B) The age of the tank to be permanently removed from service;

(C) The type of substance or material that was stored in the tank:

(D) The closure procedures to be followed;

(E) The size, type and location of the tank if it is to remain in the ground:

(F) The date of tank excavation if the tank is to be removed from the ground;

(G) Appropriate documentation substantiating compliance with the closure procedures outlined in this section: and

(3) Obtain from the DIRECTOR a certificate of closure.

(e) An owner or operator that removes any underground storage tank(s) from service for more than 180 days and has not been granted an extension of temporary closure for more than 180 days by the DIRECTOR or who has abandoned any tank(s) shall be either:

(1) Remove underground tank(s) and related facility components in accordance with part $(f)(1)$ of this section; or

(2) Allow the underground tank(s) and related facility components to remain in the ground, providing that the requirements listed under part $(n(2)$ of this section are met.

(f) Permanent closure procedures:

(I) The owner or operator may permanently close underground storage tanks by removing the tanks and related facility components provided that:

(i) all product is removed from the tank(s) and connecting lines;

(ii) the tank is cleaned to remove any residue or material in the tank, and such residue or material is disposed of in ac- cordance with applicable State and Local laws and regulations;

(iii) the gaseous vapors are released at the site in a safe manner approved by the DIRECTOR:

(iv) the DIRECTOR is given at least seventy-two (72) hours notice of the time of excavation of the underground components so that the site may be inspected for the presence of pollutants:

(v) upon request of the DIRECTOR, structural supports necessary to ensure that the excavated area can be safely and thoroughly inspected for the presence of pollutants are installed;

(vi) before disposal, a sufficient number of holes or openings shall be made in the tank(s) so as to render the tank(s) unfit for further use. No cutting torch or other flame or spark producing equipment shall be used until the tank has completely purged or otherwise rendered safe:

(vii) any excavated contaminated soil or debris is disposed of in accordance with appropriate State and Federal laws and regulations.

(2) The owner or operator of a Facility may permanently close underground storage tanks by allowing the tank(s) and/or associated facility components to remain in the ground provided that:

(i) a Precision Test is conducted on the tank(s) and associated piping of the Facility, the results are furnished to the DIRECTOR and the test reveals no leaks;

(ii) all product from the tank(s) and from all connecting lines is removed:

(iii) the tank is cleaned to remove any residue or material in the tank, and such residue or material is disposed of in accordance with applicable State and Local laws and regulations;

(iv) all fill, gauge, pump and vent lines are disconnected and all inlets and outlets are capped or plugged: and

(v) all tanks are filled completely with an inert solid material and all remaining underground piping associated with the tank(s) are capped and secured against tampering.

(g) If the Precision Test required in accordance with part $(\cap)(2)(i)$ of this Section reveals leak(s) in the tank(s) or associated piping, the DIRECTOR shall determine which, if any, components of the Facility shall be removed to investigate the extent of environmental damage.

(h) Any owner or operator of abandoned underground storage tanks shall wtihin six months from the effective date of these regulations close the tanks in accordance with the permanent closure requirements of this section.

(i) Certificate of Closure

In accordance with part (d) of this section, the owner or operator of a tank to be permanently removed from service shall apply to the DIRECTOR for a certificate of closure and shall provide the DIREC. TOR with appropriate documentation substantiating compliance with these regulations. Such documentation shall include but not be limited to the results of precision tests required. The Director shall, based upon a review of the application and other information, determine whether the Facility is in compliance with these regulations, and shall:

(I) issue a certificate of closure: or

(2) require that certain deficiencies be corrected prior to the issuance of a certificate of closure and within a specific period of time: or

(3) issue a certificate of closure with conditions such as but not limited to monitoring. reporting or site restoration re: quirements, provided, however, that no conditional certificate of closure can be transferred to a new owner or operator without conforming with the requirements of Section 17. Transfer of Certificates of Registration and Closure.

(j) Any owner or operator that has not applied for or obtained a certificate of closure in accordance with this section shall be in violation of these regulations and subject to the penalties referenced in Section 20 of these regulations.

(k) All certificates of closure issued under the "Emergency Regulations for Underground Storage Facilities Used for Petroleum Products and Hazardous Materials", adopted 9 October, 1984 shall remain in full force and effect provided the owner and operator submit a written certification in accordance with Section 16 of these regulations.

16. Signatories to Registration and Closure Applications

(a) All applications for a certificate of registration and for a certificate of closure shall be signed as follows:

(1) For a corporation: by a responsible corporate officer. For the purpose of this section, a responsible corporate officer means:

(i) a president, secretary, treasurer, or vice-president of the corporation in charge 
of a principal business function, or any other person who performs similar policy or decision making functions for the corporation, or

(ii) the manager of one or more manufacturing, production or operating facilities employing more than 250 persons or having gross annual sales or expenditures exceeding \$21 million (in second-quarter 1980 dollars) if authority to sign documents has been assigned or delegated to the manager in accordance with corporate procedures.

Note: DEM does not require specific assignments or delegations of authority to responsible corporate officers identified in 16(a)(1)(i). The DEM will presume that these responsible corporate officers have the requisite authority to sign permit applications unless the corporation has notified the DIRECTOR to the contrary. Corporate procedures governing authority to sign permit applications may provide for assignment or delegation to applicable corporate positions under $16(\mathrm{a})(\mathrm{I})(\mathrm{ii})$ rather than to specific individuals.

(2) For a partnership or sole proprietorship; by a general partner or the proprietor, respectively:

(3) For a municipality, State, Federal, or other public agency; by either a principal executive officer or ranking elected official. For purposes of this section, a principal executive officer of a Federal agency includes:

(i) The chief executive officer of the agency, or

(ii) a senior executive officer having responsibility for the overall operations of a principal geographic unit of the agency (e.g., Regional Administrators of EPA).

(4) For a military installation; by the installation Commander of a rank of 06 or higher. if the installation employs more than 250 persons and authority to sign permit applications has been assigned or delegated to the Installation Commander in accordance with applicable Department of Defense (DoD) procedures. If an Installation Commander does not meet these requirements, the permit application must be signed by a superior officer who meets the requirements.

In addition, where a tenant is present on the installation and has authority or responsibility for any aspect of the regulated activity, the Tenant Commander (rank of 06 or higher) must also sign the application. The Tenant Commander must also employ more than 250 persons and have been assigned or delegated authority to sign permit applications in accordance with applicable DoD procedures. Again, if the Tenant Commander does not meet these requirements, the permit application must be signed by a superior officer meeting the requirements.

(b) Reports. All reports required by these regulations and other information requested by the Director shall be signed by a person described in paragraph (a) of this section, or by a duly authorized representative of that person. A person is a duly authorized representative only if:

(1) The authorization is made in writing by a person described in paragraph (a) of this section;

(2) The authorization specifies either an individual or a position having responsibility for overall operation of the regulated facility or activity such as the position of plant manager, operator of a well or a well field. superintendent, or position of equiv. alent responsibility. (A duly authorized representative may thus be either a named individual or any individual occupying a named position): and

(3) the written authorization is submitted to the Director.

(c) Changes to authorization. If an authorization under paragraph (b) of this section is no longer accurate because a different individual or position has responsibility for the overall operation of the facility, a new authorization satisfying the requirements of paragraph (b) of this sec. tion must be submitted to the DIREC. TOR prior to or together with any reports, information, or applications to be signed by an authorized representative.

(d) Certification. Any person signing a document under paragraph (a) or (b) of this section shall make the following certification:

I certify under penalty of law that this document and all attachments were prepared under my direction or supervision in accordance with a system designed to assure that qualified personnel properly gather and evaluate the information submitted. Based on my inquiry of the person or persons who manage the system, or those persons directly responsible for gath. ering the information, the information submitted is, to be the best of my knowledge and belief, true, accurate, and complete. I am aware that there are signifcant penalties for submitting false information, including the possibility of fine and imprisonment for knowing violations.

(e) All owners and operators who obtained a certificate of registration or a certificate of closure pursuant to the "Emergency Regulations for Underground Storage Facilities used for Petroleum Products and Hazardous Materials" shall within 60 days of the effective date of these regulations submit to the DIREC. TOR the following signed statement:

I certify under penalty of law that all information previously submitted to the DIRECTOR was prepared under my direction or supervision in accordance with a system designed to assure that qualified personnel properly gather and evaluate the information submitted. Based on my inquiry of the person or persons who manage the system, or those persons directly responsible for gathering the information, the information submitted is, to be the best of my knowledge and belief, true, accurate, and complete. I am aware that there are significant penalties for submitting false information, including the possibility of fine and imprisonment for knowing violations.

Failure to submit the above-signed statement may be cause for the revocation for the certificate of registration or closure.

\section{Transfer of Certificates of Registra-} tion or Closure.

(a) An owner or operator of a facility may transfer the certificate of registration or of closure to a new owner or operator provided:

(1) The current certificate holder notifies the Director in writing by certified mail of the proposed transfer at least thirty (30) days prior to the proposed "transfer date" and includes the following information:

(i) Name and address of current Facility;

(ii) Name and address of new owners and operators;

(iii) Names and addresses of persons upon whom legal process can be served;

(iv) A notarized statement signed by a duly authorized officer or agent of the new owner or operator stating that he has:

(A) read the original application for a certificate of registration or closure and

(B) believes that there has been no substantial modification in the operations of 
the Facility since the certificate was is a claim for an adjudicatory hearing to sued: or

(C) describes the changes that have occurred since the certificate was issued.

(v) A proposed transfer date on which the new owner will assume the certificate and all accompanying responsibility.

(2) The DIRECTOR does not notify the existing certificate holder and the proposed new certificate holder, within twenty (20) days of receipt of notice of proposed transfer, that additional information is needed or of an intent to modify, revoke or revoke and reissue the certificate. If such notice is not received. the transfer is effective on the date specified in the notice provided to the DIRECTOR pursuant to paragraph $(a)(1)(v)$ of this section.

(3) The existing certificate of closure does not contain any ongoing conditions in which case the certificate can only be transferred upon:

(i) the receipt by DEM of a notarized statement signed by the new owner or operator stating that he agrees to abide by all conditions of the certificate; and

(ii) the express written consent of the DIRECTOR.

\section{Variances}

(a) Any owner or operator of a facility may submit a written request to the DI. RECTOR for a variance from some or all provisions of these regulations.

(b) The owner or operator shall have the burden of proving by clear and convincing evidence that a variance should be granted because alternative design or operating standards are substantially equivalent to the regulations and will have no adverse effect on public health and the environment.

(c) If the Director determines that there is widespread public interest or that the variance request raises major issues that could affect other facilities then the DIRECTOR may schedule a public hearing to solicit public comment prior to rendering a decision on the variance request.

(d) The Director's decision to grant or deny a variance shall be in writing and may, as a condition of granting the variance, impose appropriate requirements necessary to protect the public health and environment.

(e) Any person affected by the grant or denial of a variance request may, in accordance with the Administrative Rules of Practice and Procedure for the Department of Environmental Management, file review the initial decision.

19. Severability. If any provision of these regulations or the application thereof to any person or circumstances is held invalid by a court of competent jurisdiction, the remainder of the rules and regulations shall not be affected thereby. The invalidity of any section or sections or parts of any section or sections shall not affect the validity of the remainder of these rules and regulations.

20. Penalties. Penalties will be assessed in accordance with Rhode Island General Laws Chapier 46-12, 42-17.1, and $23-19.1$ for any violation of these regulations.

\section{APPENDIX A}

Definition of Hazardous Substance

Hazardous substance, as defined by section 101(14) of CERCLA, means (a) any substance designated pursuant to section 311 (b) (2) (A) of the CWA (see List 1); (b) any element, compound, mixture, solution. or substance designated pursuant to section 102 of CERCLA (see List 2); (c) any hazardous waste having the characteristics identified under or listed pursuant to section 3001 of the Solid Waste Disposal Act (but not including any waste the regulation of which under the Solid Waste Disposal Act has been suspended by Act of Congress); (d) any toxic pollutant listed under section 307 (a) of the CWA (see List 3); (e) any hazardous air pollutant :isted under section 112 of the Clean Air Act (see List 4); and (f) any imminently hazardous chemical substance or mixture with respect to which the Administrator of EPA has taken action pursuant to section 7 of the Toxic Substances Control Act (see List 5). The terms do not include petroleum, including crude oil or any fraction thereof which is not otherwise specifcally listed or designated as a hazardous substance under subparagraphs (a) through $(f)$ of this paragraph, and the term does not include natural gas, natural gas liquids, liquified natural gas or synthetic gas usable for fuel (or mixtures of natural gas and such synthetic gas).

\section{LIST 1}

Hazardous Substances - Clean Water Act Section 102

[Omitted. See 40 CFR 116.4A pub-

lished in Environment Reporter, Federal Regulations - 3 at page 131:2001.]
List 2

CERCLA Section 102 Wastes (as of None to Date. February 1985)

List 3 - Toxic Pollutants - Clean Water Act, Section 307(a)

[Omitted. See "The Federal Water Pollution Control Act" Table I published in Environment Reporter. Federal Laws at page 71:5101.]

\section{List 4}

Hazardous Air Pollutants Clean Air ActCAA Section 112 (as of February 1985)

Arsenic
Asbestos
Benzene
Beryllium
Coke Oven Emissions
Mercury
Vinyl Chloride

List 5

Imminently Hazardous Chemicals Toxic Substances Control Act,

Section 7 (as of February 1985) None to Date.

\section{APPENDIX B}

\section{SOME SUGGESTED SPECIFICA. TIONS APPLICABLE TO REGULATORY REQUIREMENTS}

ASTM-D-814, "Rubber Property
- Vapor Transmis-
sion of Volatile
Liquids"

ASTM D-543,

"Resistance of Plastics to Chemical Reagents"

ASTM D-751, "Coated Fabrics"

ASTM D-2240, "Rubber Property - Durometer Hardness

ASTM D-2684, "Determining Permeability of Thermoplastic Containers" 
ASME,

UL.58.

UL1316,

ULC-3615-1977,
"ASME Pressure

Vessel Code. Section VIII, Division

T, Boiler and Pressure Vessel Code"

"Steel Underground Tanks for Flamma. ble and Combustible Liquids"

"Glass Fiber Reinforced Plastic Underground Storage Tanks for Petroleum Products"

"Standard for Reinforced Plastic Un- derground Tanks for Petroleum Products"

ASTM G-1.72,

"Standard Recommended Practice for Preparing. Cleaning, and Evaluating

Test Specimens"

ASTM G-31-72, "Standard Recommended Practice for Laboratory Immersion Corrosion Testing of Metals"

ASTM D-4021-81, "Standard Specifcations for Glass-Fiber-Reinforced
Polyester Underground Petroleum Storage Tanks"

NACE TM-10-69,

"Laboratory Corrosion Testing of Metals for the Processing Industry"

NACE TM-02-70, "Method for Conducting Controlled Velocity Laboratory Corrosion Tests"

API 1631.

"Recommended Practice for the Interior Lining of Existing Steel Underground Tanks" Storage 


\title{
RHODE ISLAND OIL POLLUTION CONTROL RULES AND REGULATIONS
}

\author{
(Department of Environmental Management; Adopted August 12, 1957)
}

1. As used in these rules and regulations the word "person" shall be held to mean and include every individual, firm, copartnership, association, private corporation and municipal corporation, whether acting as principal, agent or servant, and whether acting personally or by agents or servants, and these rules and regulations shall apply to each and every such person.

2. As used in these rules and regulations the term "oil" shall be held to mean any petroleum, gasoline, kerosene, tar, asphalt, oil, or any product or mixture thereof.

3. As used in these rules and regulations the term "oil carrying vessel" shall be held to mean a vessel equipped to carry more than 5,000 gallons of bulk oil as cargo or as fuel for her own use.

4. No person shall discharge, or cause, suffer or procure to be discharged, or cause or suffer to escape, and liquid waste, including storm water runoff, or other waste, into any of the waters of the state from any new oil refinery, new oil storage tank farm; new industry manufacturing petroleum products, or new industry whose liquid waste or storm water runoff or other waste may contain oil, placed into operation after these rules and regulations are established by order, unless plans and specifications and a description of a system or means to be installed to prevent the es. cape of oil which may be present in such liquid waste, storm water runoff or other waste have been submitted to the Department of Environmental Management, and an order of approval of the same has been entered by said department.

5. - No person shall discharge, or cause. suffer or procure to be discharged, or cause or suffer to escape, any oil into any of the waters of the state; provided however that this rule shall not apply to any waste waters passed through any oil separating or treatment equipment approved by the Department of Environmental Management, and operated in a manner acceptable. to said department and in conformance with any standards of operation contained in said department's order of approval.
6. No person shall deposit, or cause, suffer or procure to be deposited, any oil in any place on the bank or shore of any of the waters of the state or on any wharf or pier in any such waters, where the same shall be likely to be washed into any of the waters of the state either by heavy rains, high tides, or storms, except hurricanes, or in any place where the same shall be likely to be discharged or to eacape into any of said waters.

7. No person shall pump or discharge, or cause, suffer or procure to be pumped or discharged into any harbor, river, bay, inland waters or any of the waters of the state, bilge or ballast water from any oil carrying vessel or from any other ship. barge, tanker, boat or vesel whereby any oil shall be liable to be discharged or to escape into any of the waters of the state.

8. No person shall scrape, wash, scrub, scour or swab, or cause suffer or procure to be scraped, washed, scrubbed, scoured or swabbed, any part of any ship, barge, tanker, boat or vessel, or any tank or receptacle thereon, while such ship, barge, tanker, boat or vessel is in any harbor, river, bay, or other waters of the state or on any shore thereof or in any dry dock within the state, or any oil tank or oil receptacle in any place, whereby any oil shall be liable to be discharged or to escape into any of the waters of the state.

9. No person shall transfer, or cause, suffer or procure to be transferred, any bulk oil from any oil carrying vessel to shore, or from shore to any oil carrying vessel, or ballast or cause, suffer or procure to be ballasted any oil carrying vessel unless the scuppers of any such vessel are plugged watertight during the oil transfer or ballasting operation.

10. No person shall transfer, or cause, suffer or procure to be transferred any bulk oil from any oil carrying vessel to shore or from shore to any oil carrying vessel unless the following precautionary measures against oil spillage into the waters of the state during the transfer have been taken. (a) Any flexible hose used in the transfer which has not been in regular use shall have been tested at a pressure in excess of that to which it will be subjected in use, and such test shall be made within one month previous to such use.

(b) Drip pans are placed under hose connections on the oil carrying vessel, and drip pans or a tight wharf or pier section enclosed by a curb raised to not less than four inches above the deck level is provided under the hose connections on the wharf or pier. If drip pans are used they must be in place before tight blank, as provided in ( $f$ ) of this rule, is removed and they must remain in place until blank is replaced and hose is moved. This rule shall not prevent the installation of a drain to a tight curbed wharf or pier section for the removal of storm water, provided the drain is tightly closed during any oil transfer and no oil contaminated drainage from the tight section is discharged into the waters by the state, when the drain is open.

(c) Hoses are supported so as not to become crushed between the ship and the wharf or pier.

(d) Hoses are long enough so that they will not be strained by any movement of the ship if the ship's mooring lines are adequately tended.

(e) Mooring lines are tended frequently to prevent excessive movement of the ship at the wharf or pier.

(I) Hose ends are blanked tightly when hoses are moved into position to be connected, and also immediately after they are disconnected, before they are moved away from their connections.

11. No person shall transfer, or cause, suffer or procure to be transferred bulk oil from any oil carrying vesel to shore or from shore to any oil carrying vessel unless a man is stationed on the dect of such vesed in sight of the hose and its vessel connec. tions, and another man stationed on shore in sight of the hose and its shore connec. tions, and another man stationed on shore in sight of the hose and its shore connections continuously during the transfer; 
provided, however that in the case of the transfer of oil to or from an oil barge, one man stationed where he can have a clear view of both the deck and the dock will suffice.

12. No person shall transfer, or cause, suffer or procure to be transferred bulk oil from any oil carrying vessel to shore or from shore to any oil carrying vessel after sunset and before sunrise unless decks and the wharf or pier area at the point of transfer are brightly illuminated during the transfer.

13. No person shall transfer, or cause, suffor or procure to be transferred any bulk oil from any oil carrying vessel to shore unless:

(a) All cargo risers not intended for use in the transfer are blanked.

(b) Sea valves connected to the cargo piping, and stern loading connections are tightly closed and sealed with a numbered seal.

(c) Lines and valves in the pumprooms and on deck are checked by the ship's master or senior deck officer to see that they are properly set for discharging cargo. An additional check is made for the same purpose each time the setting is changed.

(d) Means of communication with shore facilities are checked and thoroughly understood.

(e) Discharging is started slowly until shore lines are proven clear.

(I) A check valve to prevent backflow is located in the discharge line of each oil cargo pump of a centrifugal type; the check valve shall be located at a point in the discharge line ahead of any connection the line makes with the discharge line from any other cargo pump on the vessel.

(B) A copy of the "Declaration of Inspection" required by the United States Coast Guard has been handed to the terminal superintendent or his representative, who shall on demand be given the opportunity to satisfy himself that the condition of the vessel is as stated in the "Declaration of Inspection."

14. No person shall transfer, or cause. suffer or procure to be transferred any bulk oil from shore to any oil carrying vessel unless:

(a) All sea valves connected to the cargo piping, stern discharge, and ballast discharge vaives are closed and sealed with a numbered seal.

(b) All hose river valves not to be used are closed and blank flanged, and all air valves on headers are closed.

(c) Means of communication between ship and shore are ascertained and all signals between ship and shore thoroughly understood.

(d) Loading is started at a slow rate and an inspection made of the ship's tanks to determine that all is going according to plan before loading is increased to desired rate. (e) No more tanks are loaded at one time than can be safely watched and controlled.

(f) Special attention is paid during the topping-off process to the loading rate, the number of tanks open, the danger of air pockets and the inspection of tanks already. loading.

(8) To allow time for orderly control, the slow down for topping-off is anticipated and notice given to shore personnel.

(h) Water around the ship's side is inspected frequently, especially in the way of the seacocks, to insure that no oil is escaping overboard.

(i) Upon completion of loading, all tank valves and loading valves are closed. After draining, hoses are disconnected and hose risers blanked.

15. No person shall ballast, or cause, suffer or procure to be ballasted any oil carrying vessel unless:

(a) The transfer of cargo has been completed and all hose risei valves have been closed and connections blanked.

(b) If ballast is to be pumped in, whether through deck lines or bottom line; valves on the lines used are set first, then the valves to the tanks to be ballasted are opened, the necessary valves in the pumprooms, except seacocks, are set next, and cargo pumps are started before opening seacocks.

(c) If ballasting is done by gravity. ballast is pumped in first for ten minutes in accordance with the procedure outlined above in (b) to clear all bottom lines of oil.

(d) When ballasting is started, all tanks are inspected to see that only the tanks intended are receiving ballast.

(e) The same attention is given to ballasting as to topping-off tanks when loading cargo.

(I) When completing the loading of ballast, seacocks are closed before stopping the pumps.

The provisions of (a), (b), (c), (f) of this rule shall not apply to any vessel whose ballast piping system and ballast pumps are wholly independent and not connected to the cargo system.

16. No person shall discharge, suffer or procure to be discharged, the exhaust steam from any coil or other device used to heat oil, into the water of the state or into any public sewer or storm drain, or into any private drain which empties into any of the waters of the state or onto the banks of any of these waters unless such exhaust steam is first passed through an oil removal system approved by the Department of Environmental Management.

17. No person shall discharge the drainage from any underground pipe gallery used as a conduit for oil pipes, or the drainage from the floor of any boiler room where oil burning equipment is located, into a public sewer or storm drain or into the waters of the state or onto the banks of these waters without first passing the drainage through an oil removal system approved by the Department of Environmental Management. This rule shall apply only to the drainage from business and industrial establishments.

18. No person maintaining a dike around an oil storage tank shall have any openings in such dike that will permit the escape of drainage from behind the dike into any sewer or drain or into the waters of the state.

An opening such as a pipe provides, may be placed in the dike provided it is kept closed at all times except for periods, no longer than are necessary, to remove accumulated drainage. When it is necessary to remove such drainage it shall be passed thru an oil removal system approved by the Department of Environmental Management, unless it is wholly oil free. If free of oil it may be discharged as desired. If temporary openings in the dike are made to permit doing work on or inside the same, provision must be made while the openings exist to convey drainage from the dike to an oil removal system approved by the Department of Environmental Management, or other provision made to prevent such drainage from reaching the waters of the state without the removal of any oil it may contain.

19. Every person operating a terminal for the transfer of oil from ship to shore or from shore to ship shall, when a spillage of oil occurs at his terminal, take steps immediately to contain the spilled oil, and remove it from the water if any has reached it. For this purpose he shall have readily available adequate essential equipment approved by the Department of Environmental Management and personnel familiar with such salvage operations.

20. Every person operating a terminal for the transfer of oil from ship to shore or from shore to ship shall inspect every ship using his terminal and fill out the inspection report supplied to him by the Department of Environmental Management, and submit the same to said department promptly when the ship has left the terminal.

21. Every person who handles oil shall, when a spillage of oil occurs on his premises, take steps as promptly as possible to prevent the spilled oil from reaching a public sewer or drain or in any way any of the waters of the state.

22. No person shall discharge the drainage from any bulk oil plant yard, refinery area, or other outdoor area where large volumes of oil (more than 21,000 gallons) are received or stored or shipped, and where by accident or otherwise oil may escape or be spilled into any public sewer or drain or into any of the water of the state, without first passing such drainage through an oil removal system approved by the Department of Environmental 
Management. This rule shall not prevent the discharge into any public sewer areas if means are provided to retain the drainage for inspection before it is discharged and any oil free drainage is so discharged.

23. No person shall maintain a vent to any oil storage tank located on the premises of a business or industrial establishment that is filled through an opening in the top of the tank except one carried at least three feet higher than the opening, in order that the oil will first overflow at the inlet to the tank if the tank is filled beyond its capacity. This rule shall not apply to a tank used to store only fuel oil of a grade which will flow at all times without being heated.

24. No person shall maintain an inlet to an oil storage tank located on the premises of a business or industrial establishment except one so located or protected that should the tank overflow accidentally on filling, the oil will be retained near the tank and will not reach any public sewer or drain or the waters of the state. This rule shall not apply to a tank used to store only fuel oil which will now at all times without being heated.

25. No person shall permit any oil pipe to leak oil in any location where the oil may be washed or drained into a storm drain or sewer or into the waters of the state.

26. Every person shall post and keep posted such warning signs or copies of extracts of these rules and regulations as may be provided to him by the Department of Environmental Management, in a con- spicuous place where the same may be easily read, at each of the wharves and piers owned, leased, operated or controlled by such person, and at each separate parcel of land owned or leased by such person which borders on, or any part of which is within one hundred feet of any of the water within the state, and whereon there is deposited or stored at any one time, any oil, in greater. quantity than twenty-one thousand gallons.

27. These rules and regulations shall be in full force and effect on and after the first day of September A.D. 1957 and any previously issued orders establishing rules and regulations to prevent the discharge of oil into the waters of the state are hereby declared to be null and void, on and after that date. 


\section{Bibliography}

Arts, Jim and Anne Weinberg,Local Governemt options for Controlling Non-Point Source Pollution, University of Wisansin - Extension, Madisan, WI, 1981.

Beicos, S.S. ,The Water in Your Life, Poplar Library, New York, 1967.

Brooks, Richard Oliver. Municipal Environmental Ordinances, Volumes I \& II, Kingston, R.I., Comminity Planning and Area Development, University of RI,1978.

Chorley, Richard,Water, Earth and Man, Methuen \& Co, New York, 1979.

Coker, Robert,Streams, Lakes and Ponds, Harper \& Row, New York, 1968.

Department of Health(RI),Public Drinking Water Standards, Division of Water Supply, 1987.

Hynes, H.B.N. The Biology of Polluted waters, Liverpool Un. Press, London, 1963.

Kamieniecki, Sheldon, Public Representation in Environmental Policymaking: The Case of Water Quality Management, Westview Press, Boulder Co, 1980.

Kendall, James, Water Law, New England Interstate Water Pollution Control Commission, Bostan, Ma., 1970.

Kropp, Richard H., "Water Quality Enhancement Design techniques", Procedings of the Confernece on Stormater Detention Facilities, Aurg., 1982, New England College.

Ladd, Elisabeth and et al, hetlands and the hater Cycle, Massachusetts Audubon Society, Iincoln, Ma, 1975

Lanb, Berton L., Water Quality Administration: A Focus on Section 208, Ann Arbor Science Publishers, Ann AArbor, Mich., 1980.

Iay Person's Guide to hater Rights Iaw, Water Education Foundation, Sacramento, CA, 1985.

Ieopold, Iuna, Water:A Primer, W.H. Freeman and Co, San Francisco, Ca., 1974.

McHarg, Ian, Design With Nature, Doubleday and Co. Inc., New York, 1971.

Metropolitian Area Planning Council, Water Resouroes Protection Techniques, Boston, 1978.

Munroe, HF, "Activities of the Rhode Island Water Resources Board", Jounal of the New England Water Works Association, March, 1973. 
Pavani, Joseph,Handbook of Water Quality Management Planning, Van Nostrand Reinhold Co., New York, 1977.

Reeves, Clyde H. ,Funding Clean Water, Lexington Books, Lexington, Ma., 1984

Rhode Island Statewide Planning Program:

Land Use and Groundwater Quality South County, Rhode Island, Technical Paper \# 98, Sept., 1981.

Rhode Island 208 Water Quality Management Plan and Environmental Impact Statement, RI Statewide Planning Program, 1979.

Summary and Analysis of State Law Relating to Water Supply and Drinking Water Quality, Technical Paper \# 104, July, 1982.

The Governor's Conference on Water Policy, Tectnical Papers \# 110 and \# 14, Issue Paper \# 4, 1984.

Water Resaurce Issues in Land Use Policy, Technical Paper \# 122, August, 1986.

Rhode Island Erosion and Sediment Control Handbook, USDA Soil Conservation Service, Southern RI Conservation District, 1980.

Rogers, WH,Environmental Law, West Publishing Co, St. Paul, 1977.

Stoker, H.S. \& Spencer L. Emvironmental Chemistry:Air and Water Pollution, Scott Foresman, Chicago, Ill., 1976.

Subdivision regulations- All Rhode Island ordinances and subdivision regulations currently being used in all 39 cities and towns.

U.S. Enviromental Protection Agency, Water Quality Criteria, Washington, D.C., 1976

U.S. Enviromental Protection Agency, Guidelines for State and Areawide Water quality Management Program Development, Washington, D.C., 1976.

Wanielista, Martin, Stormwater Management Quantity and Quality, Ann Arbor Science Publishers Inc, Ann Arbor, Michigan, 1979.

Wright, Robert and Morton Gitelman,Land Use: Cases and Materials, Euclid v. Arbler pp 649-657, Pennsylvania Coal v. Mahon pp. 417-422, west

Publishing Co, St Paul, Minn, 1982 
IEGAL CASES:

Cram v. Chase 25 RI 98, 85 Atl. 642 (1913)

Dyer v. Cranston Print Works 22 RI 506, 48 Atl 791 (1901)

In Application and Pettion of Huie 202 NYS 2d 954, 11 AD 2d 837 (1960)

Lonsdale v. City of Woonsocket $25^{\circ}$ RI 428, 56 Atl 448 (1903)

Silver Spring B\&D Co. v. City of woonsocket 13 RI 611 (1882)

RHODE ISIAND GENERAL LAKS:

23-1-18 "Department of Health"

23-18-9 "Refuse Disposal"

23-19-1 "Hazardous Waste Managenent"

23-25 "Pesticide Control"

39-1 "Public utilities Cormsion"

45-23 "Subdivision of Land"

45-24 "Zoning Ordinances"

45-46 "Soil Erosion and sediment Control"

46-1 "Water Resources Board"

46-12 "Water Pollution"

46-13 "Public Drinking Water Supplies"

46-14 "Contamination of Drinking Water" 